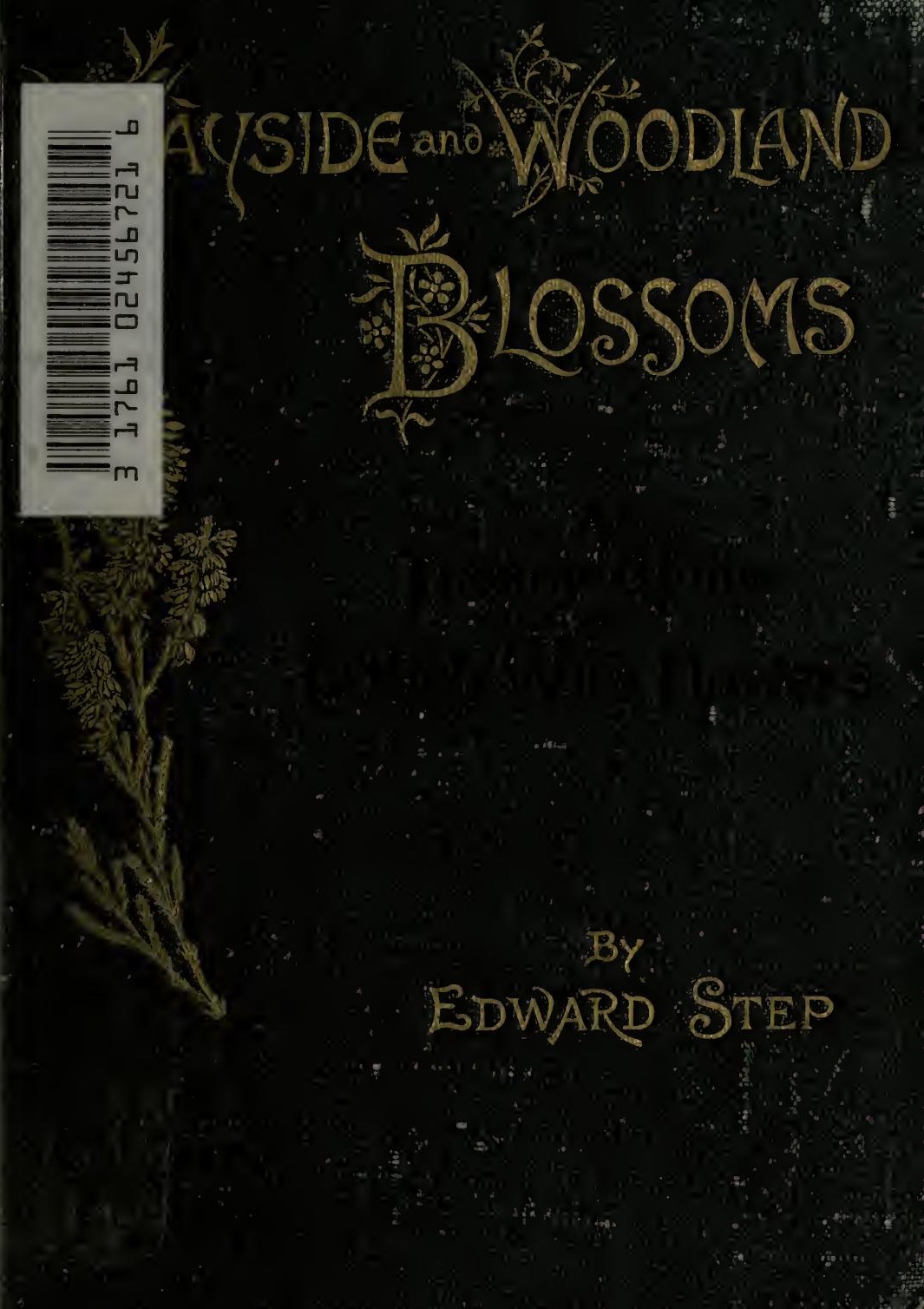



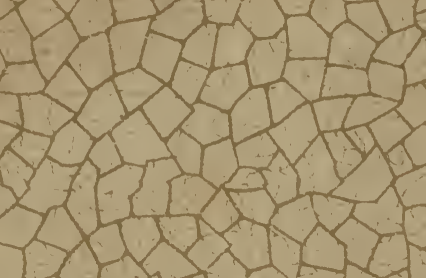

S?
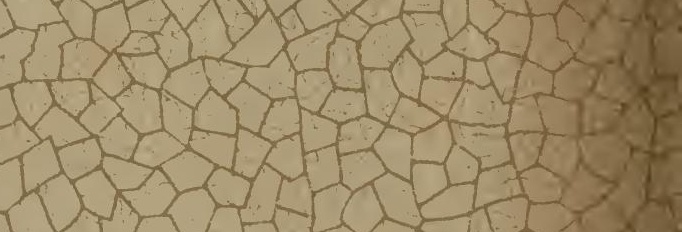

How - In

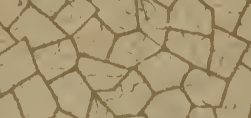

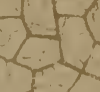

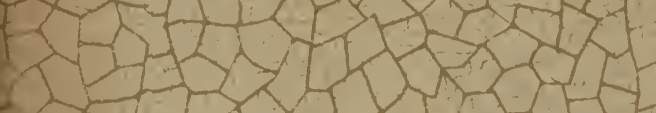

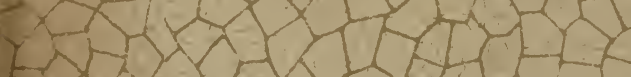
1 i

ris

3

W.

13

1)

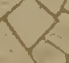

${ }_{1}+2$

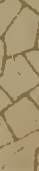

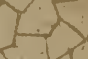

$2 \times 12$

12

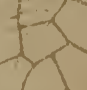

S.t?

(n)
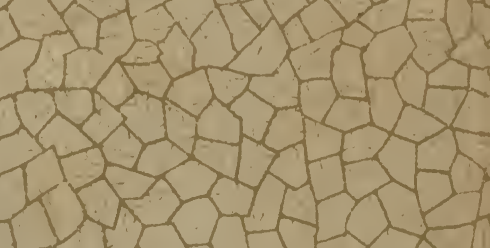


$$
\begin{aligned}
& \text { Eila trec } \\
& \text { fence } 13^{\text {th }} 1895 \\
& \text { ylom ker mitier. }
\end{aligned}
$$

WAYSIDE AND WOODLAND BLOSSOMS. 
Digitized by the Internet Archive in 2007 with funding /rom Microsoft Corporation 


\title{
Wayside and Woodland
}

\section{Blossoms}

A POCKET GUIDE TO BRITISH WILD-FLOWERS

FOR THE COUNTRY RAMBLER

\begin{abstract}
BY
EDWARD STEP

AUTHOR OF "BY VOCAL WOODS AND WATERS," "BY SEASHORE, WOOD AND MOORL.AND," ETC.
\end{abstract}

WITH COLOURED FIGURES OF 156 SPECIES BLACK AND WHITE PLATES OF 22 SPECIES AND CLEAR DESCRIPTIONS OF 400 SPECIES

LONDON :

FREDERICK WARNE \& CO. AND NEW YORK 


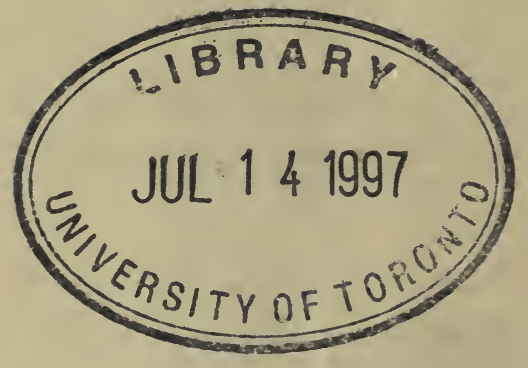




\section{P R E F A C E.}

THE purpose of this volume is to assist a very large and increasing class of persons who possess a strong love of flowers, but to whom the ordinary "Floras"-indispensable as they are to the scientific botanist-are as books written in an unknown tongue. With the enormous increase of our town populations, and the greater facilities for home travel, there has grown up a truer appreciation of the country and of all that is beautiful in nature; and it is hoped that this work may be of service to those who thus steal back to the arms of their Mother, but have not time or inclination to spell out and painfully translate the carefully-made terms of the exact descriptions which learned men have written for the use of the scientific student. Such terms are absolutely necessary, for the things they describe were unknown to our Celtic and Saxon forefathers, who would otherwise have left us names for them which would now be familiar words to all. In a work like the present such words could not be entirely avoided, but they have been used sparingly, and in a manner that will not involve continual reference to a dictionary of scientific terms. 
The Author's aim has been to write a book that, whilst it satisfied the rambler who merely wishes to identify the flowers by his path, might also serve as a stepping-stone to the floras of Hooker, Bentham, and Boswell-Syme ; so that should the interest of any reader be sufficiently awakened he may take up the more serious study of either of these authors without having to unlearn what this modest pocket-book may have taught him. At the same time he will here find information on many points of great interest, such as are rarely, if ever, noticed in the "Floras."

When it is stated that the "London Catalogue of British Plants"-meaning only the flowering plants and fernsincludes nearly 1,700 species, it will be understood that an inexpensive work for the pocket of the rambler can only give figures of a few of these; but the Author has tried to so use the I80 plants delineated that they may serve as a key to a much greater number of species. He regrets that technical difficulties connected with colour-printing and binding have made it impossible to carry out his original plan of grouping the plants according to their natural affinities; instead, he has had to arrange them more in seasons, a course which, after all, may be preferred by the rambler, who will thus find in contiguous pages the flowers he is likely to meet in the course of one ramble. The more scientifically inclined may find the species enumerated in the Natural Orders at the end of the work (page I 53).

Several of the black and white figures are of trees which are not natives, but from the frequency with which they are now planted in woods and parks the question of their identity is 
constantly troubling the rambler, and it seems well to give him the power to decide what they are.

In conclusion, the Author would but express the hope that the present volume may receive a similarly encouraging reception to that which has been accorded to his previous efforts to popularize one of the most delightful branches of human knowledge.

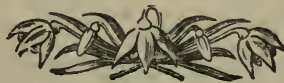




\section{WAYSIDE AND WOODLAND BLOSSOMS.}

\section{$\rightarrow$ \\ The Daisy (Bellis perennis).}

So widely distributed and well known is this plant that surprise may be felt at its inclusion here ; but its perfect familiarity marks it as a capital type of the important natural order to which it belongs. What is commonly known as the flower is really a corymb or level-topped cluster of many densely-packed florets of two kinds. Those of the central yellow disc consist each of a tubular corolla, formed by the union of five petals, within which the five anthers unite to form a sheath round the central pistil. The outer or ray-florets have the corolla developed into an irregular white flag, which at once renders the composite flower conspicuous and pretty. These outer florets produce pistils only, as though the extra material necessary for the production of the white flag had made economy in other directions a necessity, and had prevented the development of anthers and pollen.

This is the only British species of its genus, which derives its name from the Latin Bellus, pretty. Its second, or specific, name signifies that the plant lives for several years. It flowers nearly all the year round, and occurs generally in grassy places throughout the British Islands.

The Natural OrderComposita, to which Bellis belongs, includes 


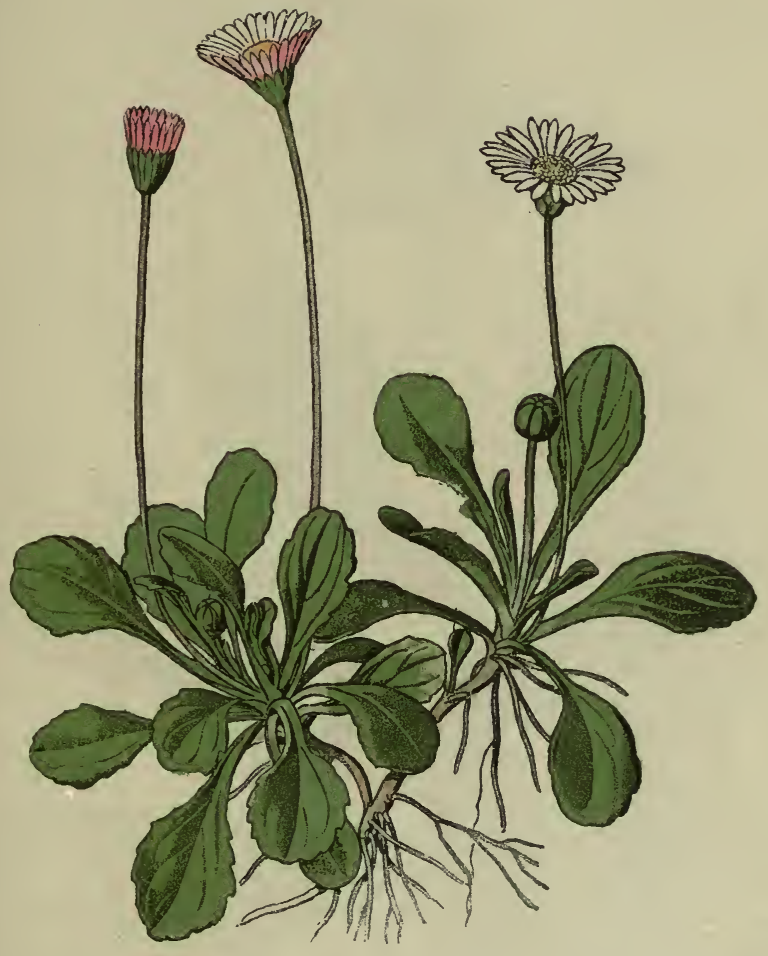

Daisy.

Bellis perennis.

- Composita. - 


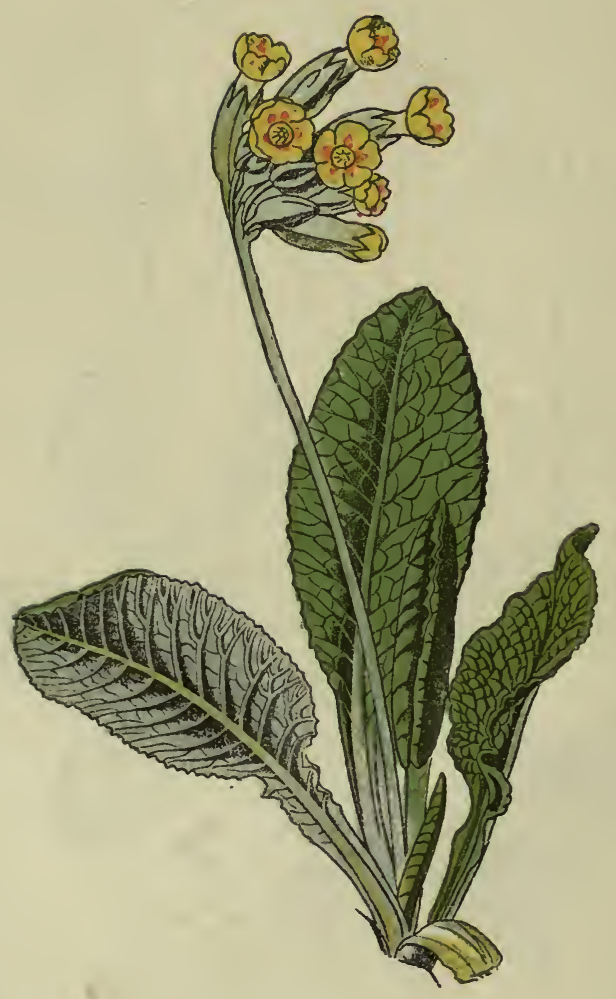

Cowslip. Paigle. Primula veris.

- Primulacede. - 
noless than forty-two British genera, which are divided into two series. Several of these genera will be illustrated and described in succeeding pages, but in all the flower-heads will be found to be constructed in the main after the manner of the Daisy. Some will be found to have no ray-florets, others to be composed entirely of ray-florets; and all these modifications of the type give the distinctive characters to the various genera.

\section{The Cowslip or Paigle (Primula veris).}

In April and May in clayey meadows and pastures throughout England and Ireland the Cowslip is abundant ; in Scotland rare. The flowers are of a rich yellow hue, and funnel-shaped, the five petals being joined to form a long tube. They are borne on short pedicels, a number of which spring from a long, stout, velvety stalk, three to six inches high. At the bottom of the tube is the globose ovary, surmounted by the pin-like style with the spreading stigma at the top. The five stamens are attached to the walls of the tube-in some flowers half-way down, in others at the top. In the first form the style is very long, so that the stigma comes to the top of the tube; in the second the style is short, and the stigma reaches half-way up only. The flowers are consequently termed dimorphic, and the two forms are borne on separate plants.

Though these two forms had long been known to country children as "pin-eyed" and "thrum-eyed" respectively, it remained for Charles Darwin to point out the significance of this variation, which is to ensure cross-fertilization by the visits of insects. A bee pushing its tongue to the bottom of a longstyled flower in search for honey would have its tongue dusted with pollen half-way down, and on visiting a short-styled flower some of this pollen would be sure to become detached by the sticky stigma at the same height; and vice versá. The reader may prove this experimentally by selecting flowers of the two 
forms, and gently thrusting a grass stem into one after the other.

The other native species of the genus Primula are :-

The Primrose ( $P$. vulgaris) with inflated calyx and large pale-yellow corollas on long pedicels. The thick stalk of the cowslip is not developed here, but hidden amid the leaf-stalks. Copses and hedge banks, April and May.

The Oxlip ( $P$. elatior). Calyx less inflated, corolla pale, like primrose ; pedicels shorter; thick stalk developed and long like cowslip. Confined to counties of Bedford, Cambridge, Suffolk and Essex. Copses and meadows, April and May.

The Bird's-eye Primrose ( $P$. farinos $)$. The three former species have wrinkled leaves; this and the next have not, but theirs are very mealy underneath. Flowers pale purple-lilac with a yellow eye. Bogs and meadows from York northwards. Very rare in Scotland. June and July. Dimorphic like the foregoing.

The Scottish Primrose (P. scotica). Similar to Bird's-eye, but not half the size, though stouter in proportion. Flowers purple-blue with yellow eye. Not dimorphic. Pastures in Orkney, Caithness and Sutherland, June to September.

Name from Latin Primulus, first.

\section{The Wood Anemone or Windflower (Anemone} nemorosa).

One of the earliest of spring-flowers to greet us in the copse, by the woodside and in upland meadows is this bright-faced flower. Its firm, fleshy, almost woody rootstock creeps just below the surface of the mossy soil, and rapidly sends up its stems with folded leaves and drooping buds, after one or two genial days.

The Anemones constitute the genus Anemone of the natural ordera Ranunculaceæ, and are characterized by having no corolla (petals). Instead, the six sepals (calyx) are coloured-in this case a very delicate pink-washed white inside, lightly tinged with purple outside. As a rule the stem bears three leaves, each split up into three leaflets, which are deeply toothed. Flowers from late March till early June. The name is derived from the Greek anemos - the wind-and was given because it was believed to open its buds only when the winds were blowing. Richard Jefferies, curiously ignoring the meaning of the word, entitled a chapter in one of his earlier works-" Wind Anemones." 


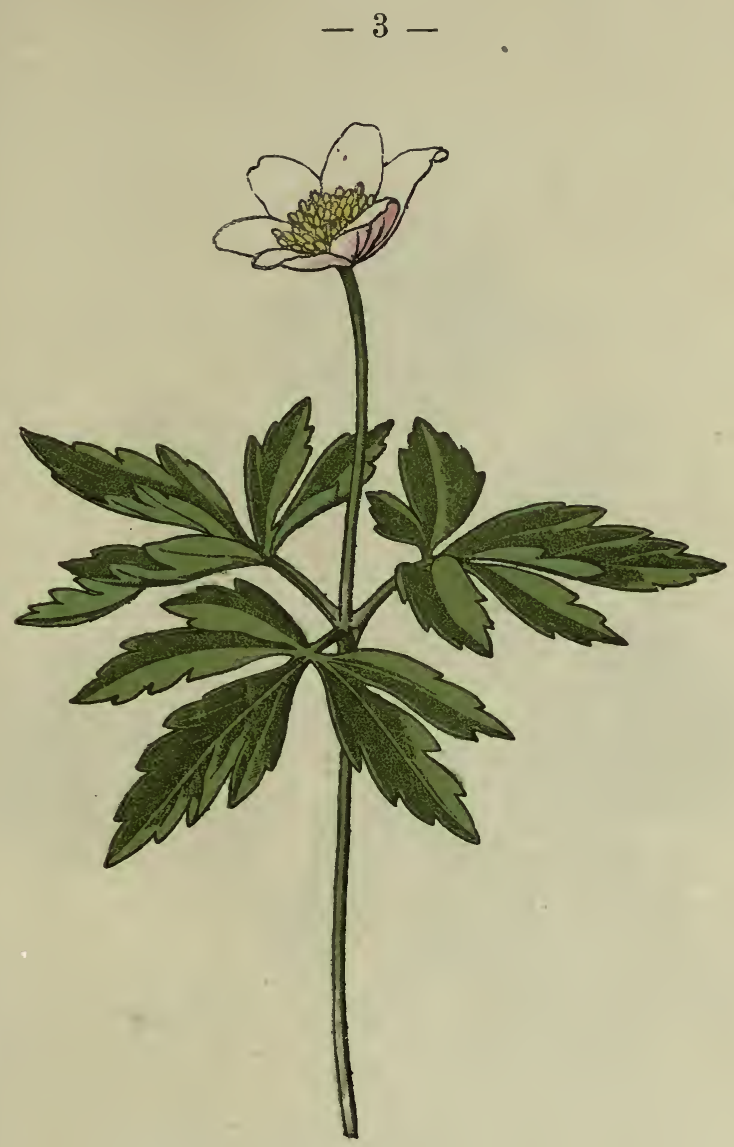

Wood Anemone.

Anemone nemorosa.

- Ranungulages. - 


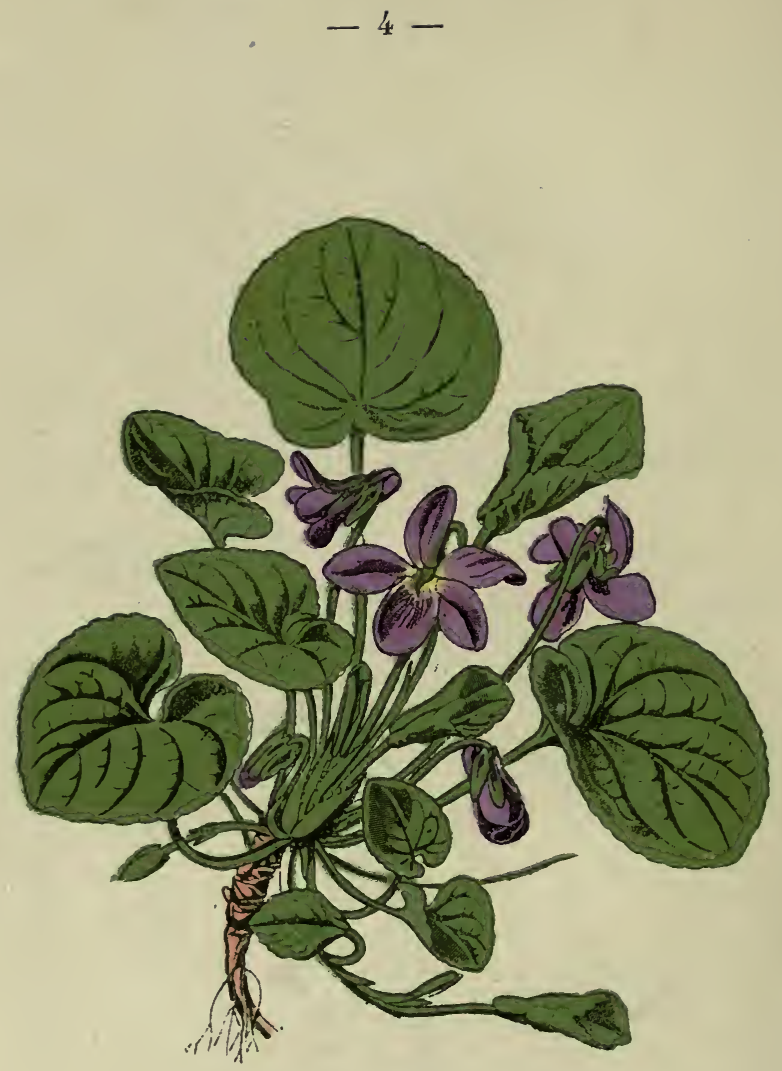

Sweet Violet.

Viola odorata.

- Violaces. - 
There is one other native species :--

The Pasque-flower $(A$. pulsatilla). Blossoms before the leaves mature. Flowers dull purple; exterior covered with silky hairs; leaves also silky. Fruit, little nutlets (achenes) provided with long feathered awns, with which they float on the wind when ripe. Flowers, May and June, on chalk downs and limestone pastures in Essex and Gloucestershire, and from York to Norfolk.

\section{The Sweet Yiolet (Viola odorata).}

One of the most valued flowers of spring in cities is the cultivated violet, and the rambler from town considers himself fortunate if he comes upon a sheltered bank whereon the wild Sweet Violets grow. We need not dwell at any length upon the special characters of this species, for its possession of sweet perfume is sufficient alone to separate it from the related species comprised in the genus Viola.

It will be seen to have a short rootstock, and to give off runners. The leaves are broadly heart-shaped, and have a way of enlarging after the plant has flowered-a characteristic shared by the Marsh Violet and the Hairy Violet. The flowers vary in colour; they may be blue, reddish-purple, or white. The petals are unequal in size and shape, there being two pairs and an odd one. This is larger than the others, and is produced backwards as a short hollow spur. It is really the uppermost of the five petals, but, owing to the flower-stalk (peduncle) invariably bending over near the summit, it appears to us always as the lowest.

A careful examination of the form and mechanism of the essential organs of this genus will be well repaid by the light thrown upon Nature's methods to secure the continuity of species. The style on arising from the ovary is thin and bent, but gradually expands until the stigmatic surface is very broad in comparison. The stamens surround the style, the anthers so closely touching each other laterally that they enclose a space in which the ovary and style occupy the centre, and from which 
the stigma protrudes. The anthers shed their pollen, which is $d r y$, into this space. Two of the stamens send out each a long tail into the hollow petal-spur, which secretes honey from its tip. The reason why the flower-stalk bends over is, that the stigma may hang down instead of being erect. A bee smells the honey and alights on the odd petal. The dark lines converging to the spur show where the honey lies, but the thickheaded stigma blocks the way. Thrusting in his tongue, the bee pushes the stigma aside with his head, which is the more easily accomplished owing to the thin base of the style. But this act also disarranges the anthers, and as a result the loosc pollen drops out upon his hairy head, where it will come in contact with the viscid stigma of the next violet he visits. In this way an occasional cross is effected that the vigour of the race may be maintained, but for ordinary purposes of reproduction the violet has a more economical method. When the spring season is over the violet ceases to furnish flowers got up for show, and sets about producing buds which will never open (cleistogamous). These are without petals, and contain nothing but the essential organs; the anthers produce only enough pollen to fertilize the ovules in the ovary, which then develop into perfect seeds.

Viola odorata is found truly wild only in the S. and E. of England, and possibly the E. of Ireland ; but it is naturalized in many other parts of the kingdom. Flowers, March to May. The name Viola is Latin, and is that by which the ancients knew it. There are six other British species, which will be found enumerated on page 58 .

\section{The Lesser Periwinkle (Vinca minor).}

The Lesser Periwinkle is perhaps more familiarly known as a garden plant than as a wild-flower, and the former would appear to be its true character. It is now truly wild, in the 


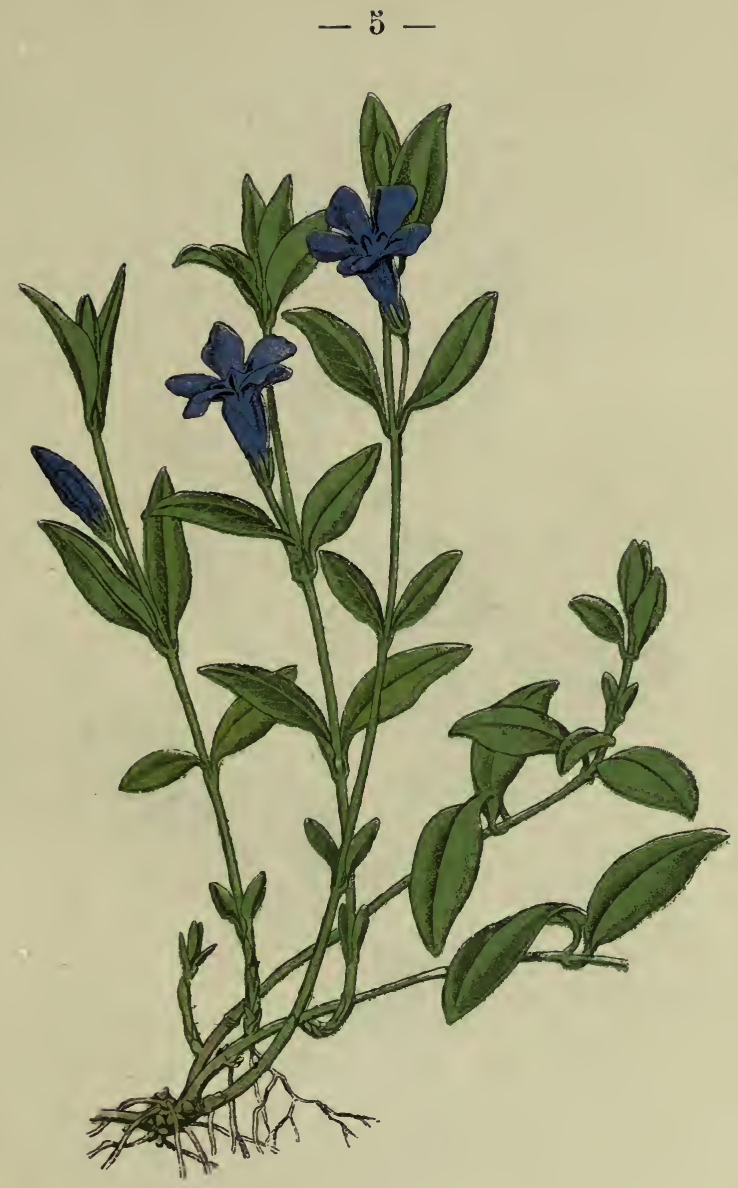

Lesser Periwinkle.

Vinca minor.

- APOGYNEA. - 
$-6-$

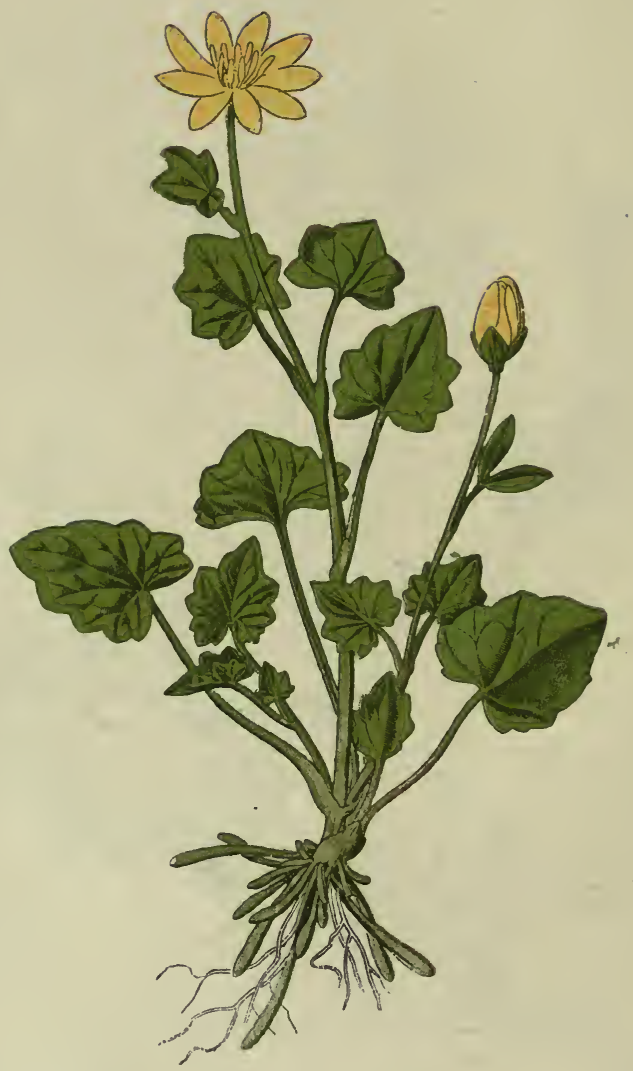

Lesser Gelandine. Pilewort.

Ranunculus ficaria.

- Ranunculaceze. - 
Southern English counties at least, having probably been introduced by man at an early date (Chaucer mentions "fresh pervinke rich of hew "), and taken care to keep the foothold thus obtained. Its favourite position is a woodland bank, which it thickly covers with its dark evergreen leaves. Hooker ("Students' Flora," p. 268) describes the flowering stems as short and erect, and the peduncles not so long as the diameter of the corolla. As a matter of fact, the long trailing and rooting stems also bear flowers, and the peduncles vary in length from $\frac{1}{4}$ to 2 inches.

The petals are united for half their length to form a tube, and the five free lobes are oblique. The structure and arrangement of the stamens and pistil are very curious, and evidently have relation to cross-fertilization by insects, for the throat of the corolla-tube is closely guarded by a fringe of silky hairs, impassable by the thrips that vainly haunt the mouth in quest of pollen. The plant rarely, if ever, produces seed in this country, and this indicates that the insects necessary to its fertilization are not British. Flowers, April and May, and sparingly throughout the year.

The Greater Periwinkle (Vinca major) is also naturalized in places. It is much larger in every respect than $V$. minor. The name of the genus is supposed to have been derived from the Latin Vincio, to bind or connect, in allusion to the manner in which its trailing stems thrust down a root from every node.

\section{The Lesser Celandine (Ranunculus ficaria).}

As soon as there comes a slackening of the iron rule of winter, whether it be early in February or late in March, then on sunny banks and at the feet of pasture-hedges, or on wasteground by the roadside, the burnished gold stars of the Lesser Celandine glitter in the wintry sunshine. It is a charming little plant in its brightness and compactness, and not in the least 
suggestive of weediness ; yet, if introduced into the garden it can become an absolute nuisance. Its roots produce a large number of cylindrical tubers, which-when the "doctrine of signatures" was in fashion-were held to resemble hemorrhoids, and therefore to be medicinal for that painful malady. hence one of its folk-names-Pilewort. Each of these tubers is capable of producing a new plant, and reproduction by this method is speedily effected.

The leaves vary much in shape and in size. The larger, from the root (radical), are more or less heart-shaped, the edges bluntly angled; the smaller ones, from the stem (caudal), may approach towards the form of an ivy-leaf. The sepals (calyx) vary from three to five, usually three, and the petals from seven to twelve. The stamens are numerous, as also are the carpels or divisions of the fruit. As in the Anemone (page 3), these are achenes, a form persistent throughout the genus Ranuinculus; each contains a single seed. The plant is well distributed throughout the country, and may be found in flower until May.

\section{The Broom (Cytisus scoparius).}

The Broom is sadly liable to be confounded with the Furze by the non-botanical rambler, chiefly, we believe, because of the similarity of the flowers and the partiality of both for heaths and commons. There are, however, several points of difference between them; but one is sufficient for a rough-and-ready distinction. The Furze began life with a few leaves similar to those of the Broom, but as it grew it put forth sharp spines instead of ordinary leaves, until it became more difficult to handle than any hedgehog. The Broom rarely puts on any prickles at all, and its compound leaves, of three small leaflets, may be seen as in the illustration, close to the pliant stems. 


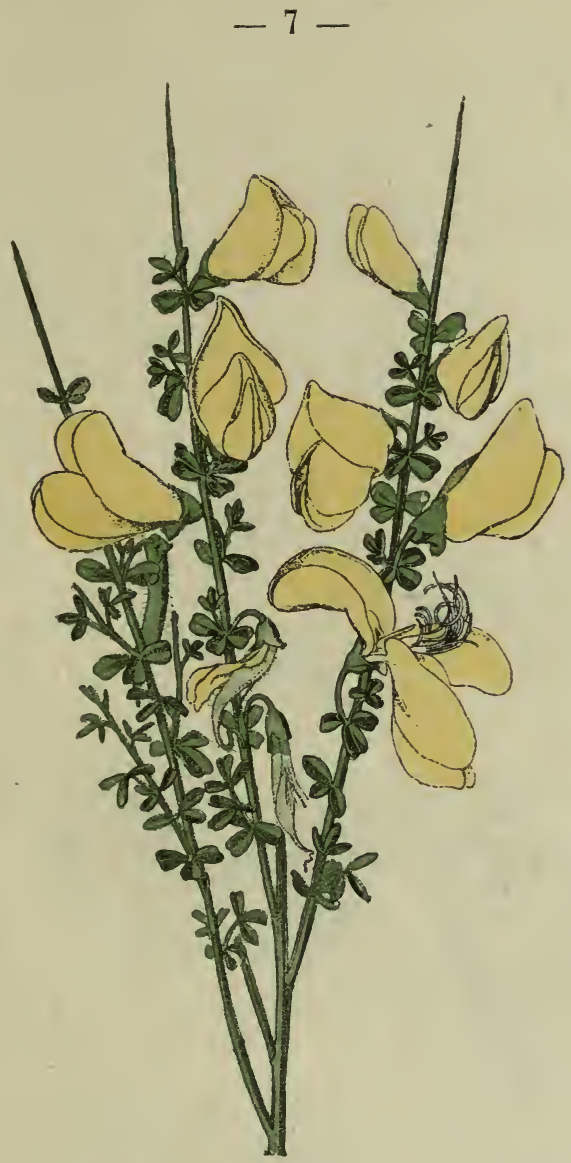

Broom.

Cytisus scoparius.

- Leguminos. 
$-8-$

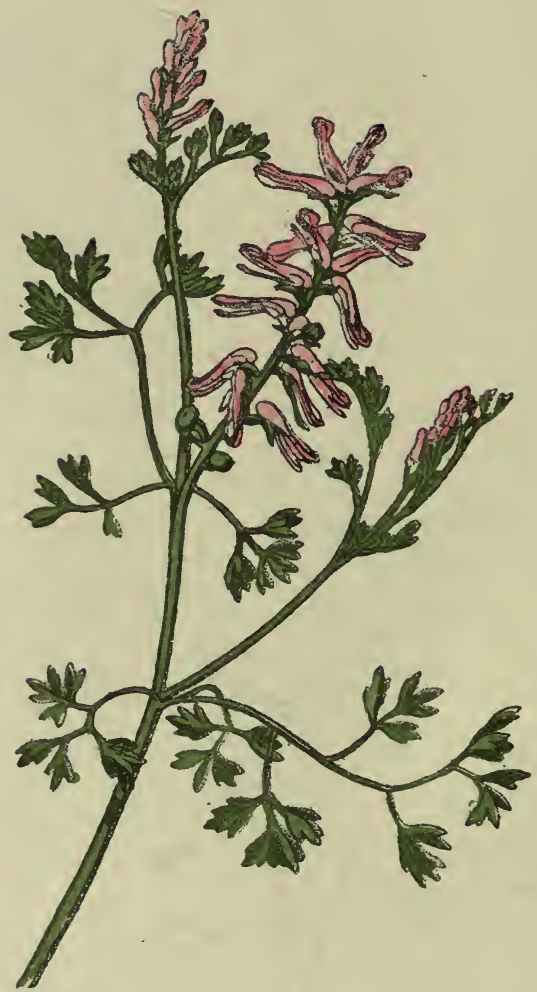

Fumitory.

Fumaria officinalis.

- Fumariaces. - 
The flowers, too, are larger than those of the Furze, though similar in structure. The calyx is two-lipped, the petals five, unequal in size and shape. The very large upper petal erects itself somewhat, and is known as the "standard." The two lateral ones are called "wings," and the lower pair are united all along their lower edges, to form a boat-shaped body, called the "keel." In this keel lie the stamens and pistil, which are curved, and the former have the filaments united into a tube within which lies the ovary. The stamens also vary in length, and should a bee alight on a newly-opened blossom in quest of pollen-for the Broom produces no honey-the pressure of the "wings" upon the "keel" forces out the shorter stamens, and they dust the bee's abdomen with pollen. Should, however, the insect visit a flower lower down the stem and consequently a day or two older, the long stamens and the pistil spring out with some force, and the hairs on the pistil brush out the shedpollen from the "keel" and sprinkle it on the bee's back. Then the pistil curls so that the stigmatic surface shall come in contact with the abdomen of the next bee that arrives, probably with pollen from another flower. Thus fertilized the ovary develops into a valved pod like that of the garden pea, but smaller, of course, and black. When ripe the valves separate, twist up and scatter the seeds. Press down the wings with the finger in the position a bee would occupy, and observe the action of this remarkable mechanism, which, with variations, is common to all Leguminous plants (see pages 43, 44, 47, $48,49,52,73,94$, 101, I 32 ). The Broom flowers from April to June, and is widely distributed throughout the kingdom.

\section{Fumitory (Fumaria officinalis).}

I have frequently found that the grace and lightness of the Fumitory suggest to the non-botanical mind some kind of relationship with the Maidenhair-fern; more especially is this 
the case with the lower portion of the plant. The leaves are thin and much divided. The flowers are peculiarly formed, and their arrangement is known as a raceme. Each consists of a couple of small sepals, and four petals arranged in two unequal pairs; the upper petal is spurred at the base, the lateral pair connected by their tips and completely enclosing the stamens and pistil.

The plant is common in dry fields and waste places throughout the three kingdoms, and indeed over a great part of the earth, for it is a plant that has followed close in the wake of cultivation. The name is an ancient one, derived from the Latin, fumus, smoke, some have said on account of the light unsubstantial character of the plant; but, according to Pliny, because the watery juice brought on such a flow of tears that the sight was dimmed as by smoke. This is not very satisfactory; but nothing better in the way of explanation has been offered, so we must be content with it. It had formerly a great reputation in medicine. Flowers from May till September.

There are three other British species :-

Rampant Fumitory ( $F$. capreolata) which climbs to a height of $\mathrm{x} \frac{1}{2}$ to 2 feet by means of its twisting leaf-stalks. Its cream-coloured flowers are more loosely borne in the raceme than in $F$. officinalis. Small-flowered Fumitory ( $F$. densiflora), similar to $F$. officinalis, but smaller and weaker, flowers paler, racemes short, leaflets smaller and narrower.

Least-flowered Fumitory (F. parziflora), with small pale flowers and minute sepals; racemes dense.

These three species are rare, the last especially so.

\section{Lungwort (Pulmonaria officinalis).}

Occasionally in woods and copses the rambler will come across this plant, which flowers in April and May. It is not truly a native, but has become naturalized in England and the South of Scotland. Time was when well-nigh every garden had its clump of Lungwort, for it had a splendid reputation 


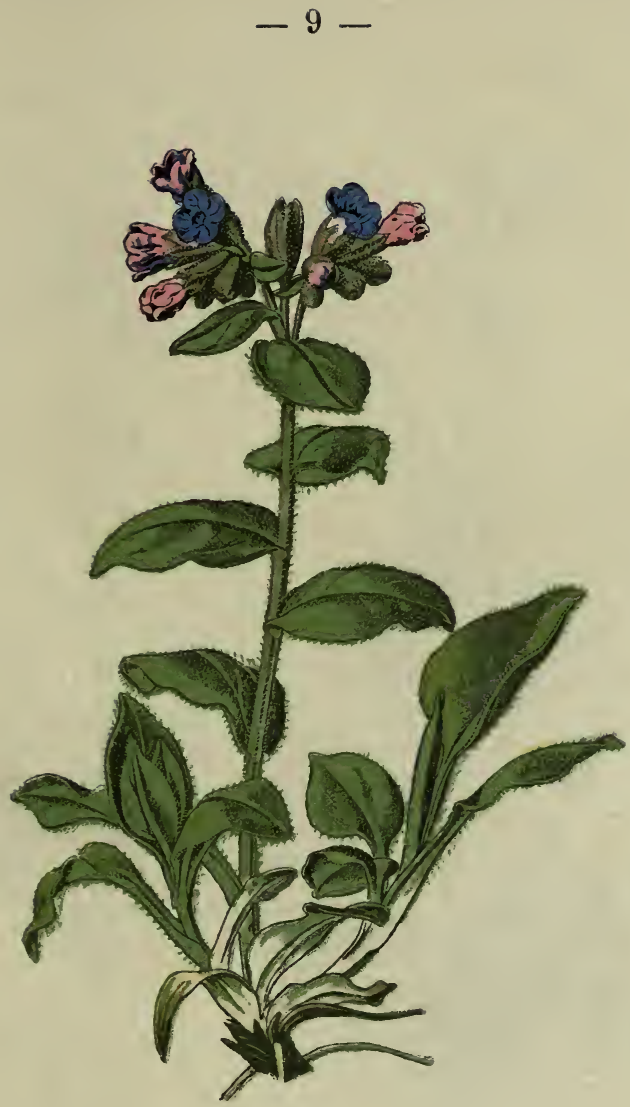

Lungwort. Jerusalem Cowslip. Pulmonaria officinalis.

- BORAgINE⿸⿻一 - 

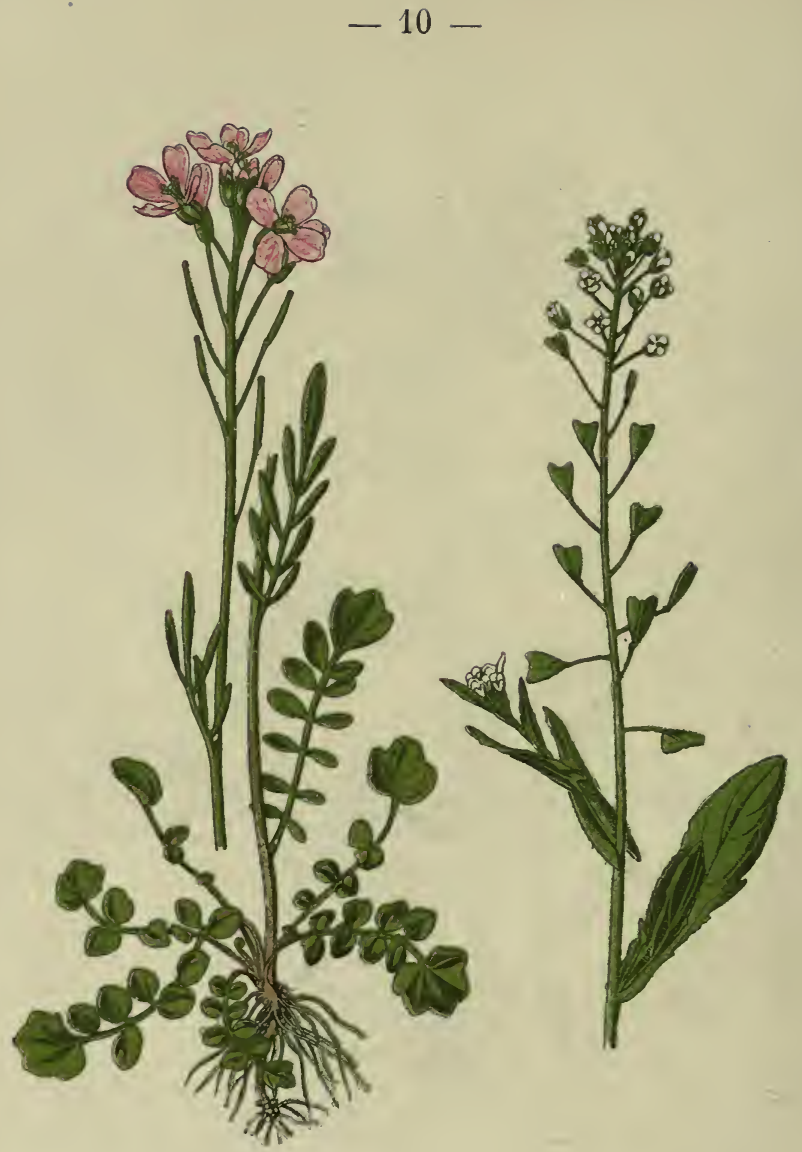

Lady's Smock. Guckoo-flower. Shepherd's purse. Cardamine pratensis. Capsella bursa-pastoris. 
for chest complaints. It is from these garden specimens that our naturalized plants have originated.

Lungwort has a creeping rootstock, from which arise stalked, ovate, hairy leaves, dark green in colour, with white blotches. On the erect flowering stem the leaves are smaller and not stalked. The flowers consist of a five-angled calyx, a funnelshaped corolla with five lobes, five stamens, style arising from a group of four nutlets and terminated by a rounded stigma. Like the cowslip, Lungwort is dimorphous. It secretes plenty of honey, and is consequently much visited by bees. Before the flowers open they are pink, but afterwards change to purple. As a garden flower it is also known as the Jerusalem Cowslip.

The name is from the Latin, Pulmo, the lungs, in allusion to the leaves, spotted like the lungs, and which under the doctrine of signatures was held to indicate that it was good for consumption and other lung troubles.

There is another species which is really indigenous to this country, the Narrow-leaved Lungwort ( $P$. angustifolia), but it is very rare, and occurs only in the Isle of Wight, the Nẹw Forest, and in Dorset. It is taller than $P$. officinalis, the leaves of a different shape, and the corolla finally bright blue.

\section{Lady's Smock (Cardamine pratensis).}

In all moist meadows and swampy places, from April to June, the eye is pleased with a multitude of waving flowers which in the aggregate look white, but at close quarters are seen to be a pale pink or lilac. They are Shakespeare's "Lady's smocks all silver-white," that "paint the meadows with delight." It is our first example of the Cruciferous plants, the four petals of whose flowers are arranged in the form of a Maltese cross. Its leaves are cut up into a variable number of leaflets; those from the roots having the leaflets more or less rounded, those from the stem narrower. The radical leaves as they lie on the 
wet ground root at every leaflet, and develop a tiny plant from each. The flowers are nearly $\frac{3}{4}$ of an inch across.

There are three other native species :-

Hairy Bitter Cress (C. hirsuta), with white flowers, $\frac{1}{8}$ th of an inch in diameter ; anthers yellow.

Large-flowered Bitter Cress (C. amara), with creamy white flowers $\frac{1}{2}$ inch in diameter; anthers purple. Riversides: rare.

Narrow-leaved Bitter-Cress (C. impatiens), white flowers, $\frac{1}{4}$ inch across; anthers yellow. Shady copses, local.

Name from the Greek Kardamon, a kind of watercress.

\section{Shepherd's Purse (Capsella bursa-pastoris).}

One need not travel far to find a specimen of Shepherd's Purse, for almost any spot of earth that man has tilled will furnish it. Wherever his fork or spade has gone in temperate regions this plant has gone with him, and stayed. The flowers are very minute, white, and are succeeded by the heartshaped seed-vessel (capsule) which gives its name to the whole plant, from its resemblance to an ancient form of rustic pouch. This splits into two valves, and the numerous seeds drop out. The only native species : flowers throughout summer.

Name : Latin, diminutive of Capsula, a little box.

\section{The Wood Sorrel (Oxalis acetosella).}

One of the most graceful and charming of native plants. It abounds in moist shady woods, rapidly covering the leaf-mould with its fresh yellow-green trefoils and pink-streaked white flowers. In such a situation in April or May it produces beautiful effects. A favourite position for it is the rotten centre of some old beech stump, from which it will spread in a loose cluster, "covering with strange and tender honour the scarred disgrace of ruin," as Ruskin says of the lichens.

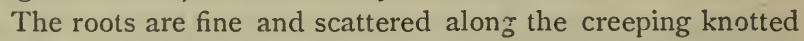
pink stems. The leaflets droop close to the stalk at night or 


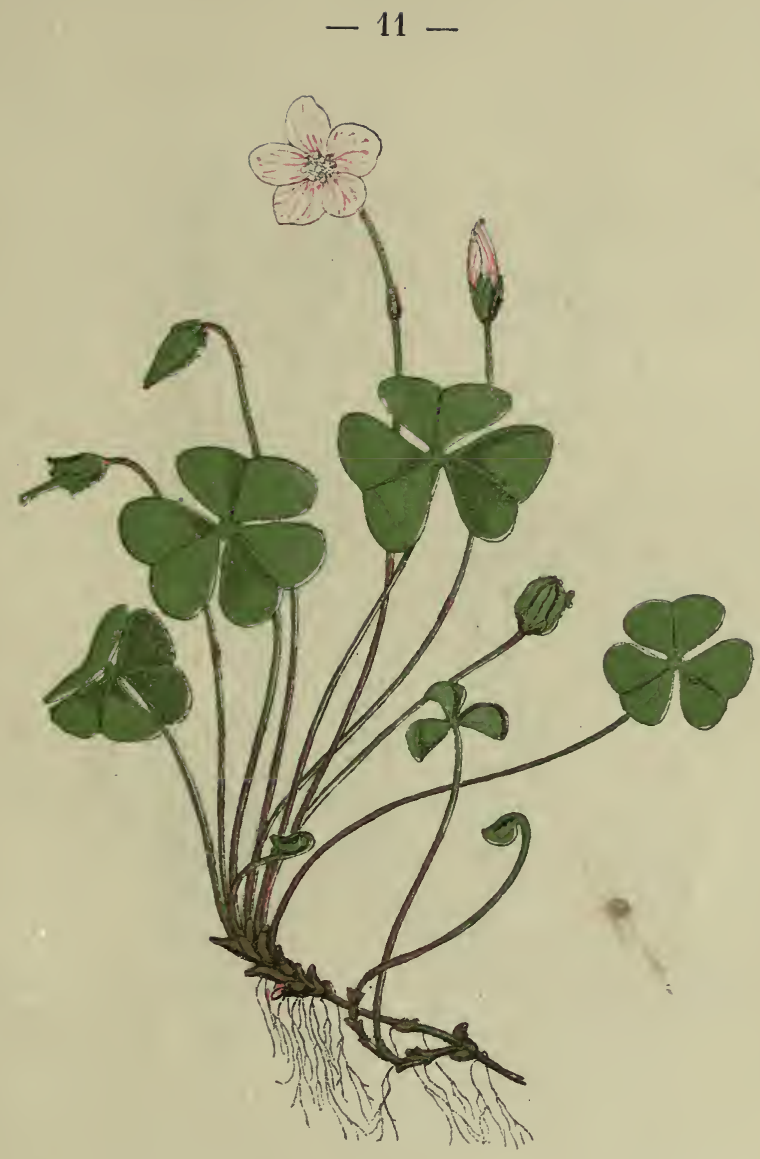

Wood Sorrel.

Oxalis acetosella.

- Oxalidere. - 


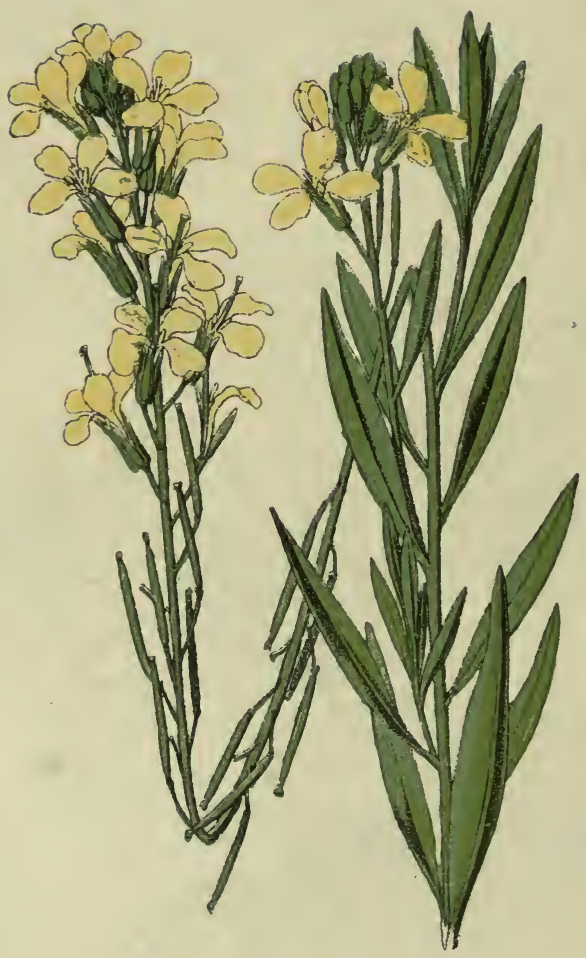

Wallflower. Wall Gillyflower.

Cheiranthus cheiri. 
on the approach of rain. The flower is regular; sepals five, petals five, stamens ten, stigmas five. The fruit is a fiveangled, irritable capsule, from which the seeds are thrown with great force to a distance of several yards. In addition to the coloured spring flowers the Wood-Sorrel produces throughout the summer a large number of buds which never open (cleistogamous), but which develop into seed-vessels and discharge good seeds. The leaves have a pleasant acid flavour, due to the presence of oxalic acid. The generic name refers to this fact, and is derived from the Greek Oxys, sharp.

This is the only truly native species, but two others with yellow flowers have become naturalized in the S.W. of England. These are :

Procumbent Wood-sorrel $(O$. corniculata), with much-branched stalk; both stalk and branches soon becoming procumbent; and the flowers borne two or three on one peduncle. Leaves and stalks bronzed. Flowers June to September.

Upright Yellow Wood-sorrel ( $O$ : $^{\text {stricta }}$ ), similar to the last, but with stem more erect; flowers two to eight on one peduncle.

\section{The Wallflower (Cheiranthus cheiri).}

This is not a British plant, though it has become firmly established on many old ruins throughout the country. It is a native of Central and Northern Europe, and according to Loudon was introduced to England in 1573 . It is never found growing on rocks in this country, as would be the case were it a native. In some districts it is known as Gillyflower, a name corrupted from the French, Giroflée de Muraille. Old writers who use the name Gillyflower refer to the Clove Pink; in the present day the plant usually intended by the term is the Garden Stock. Culpepper calls this Winter Gillyflower. The wild plants are always the single yellow variety.

It is a Cruciferous plant, like the Bittercress and Shepherd's Purse, and the structure of the flowers is very similar to those. The sepals are very long, and for economy's sake that part of 
the petal that is hidden within the calyx is a narrow claw. The long ovary is surmounted by the two-lobed stigma, and develops into a long pod, 2 or $2 \frac{1}{2}$ inches long, containing a large number of reddish seeds. It flowers in May and June chiefly, but also irregularly in mild winters.

It is the only species occurring wild, but in the garden it has produced many grand varieties. The name is most probably derived from the Greek, cheir, the hand, and anthos, flowerthat is a flower suited by its fragrance to be held as a bouquet.

The Cruciferæ, to which these plants belong, is an important Natural Order, con . taining five-and-twenty British genera and a great many species. All are distinguished by the cruciform flowers, by mears of which $\mathrm{a}^{-}$botanist can distinguish a crucifer at once. Many of our most important garden and kitchen herbs are crucifers, including the majority of our green vegetables and roots, such as cabbage, turnip, radish, mustard (see p. 9o), cress, kale, etc.

\section{Marsh Marigold (Caltha palustris).}

In marshes and river-meadows in spring this is the most conspicuous plant, and to acquire it the rambler will not hesitate to risk getting wet feet. What time the sallow first puts out her silvery "palm," the Marigolds then "shine like fire in swamps and hollows grey" (Tennyson). In some districts it is the May-blob, Mare-blob, and Marybud. It has a thick, creeping rootstock, and broadly heart-shaped glossy leaves with very large stipules. After flowering the leaves increase in size considerably, and in some places they reach an enormous size for so small a plant. The flower has no petals, but the five sepals are enlarged and richly coloured, as with gold, and burnished. The centre of the cup is occupied by a number of carpels, which are surrounded by an indefinite crowd of stamens, and which develop after fertilization into as many follicles containing great store of seeds. The plant is poisonous. The flowering time lasts from April till August.

There is one other British species-some say it is a mere variety of the foregoing-Rooting Marsh Marigold (C. radicans), 


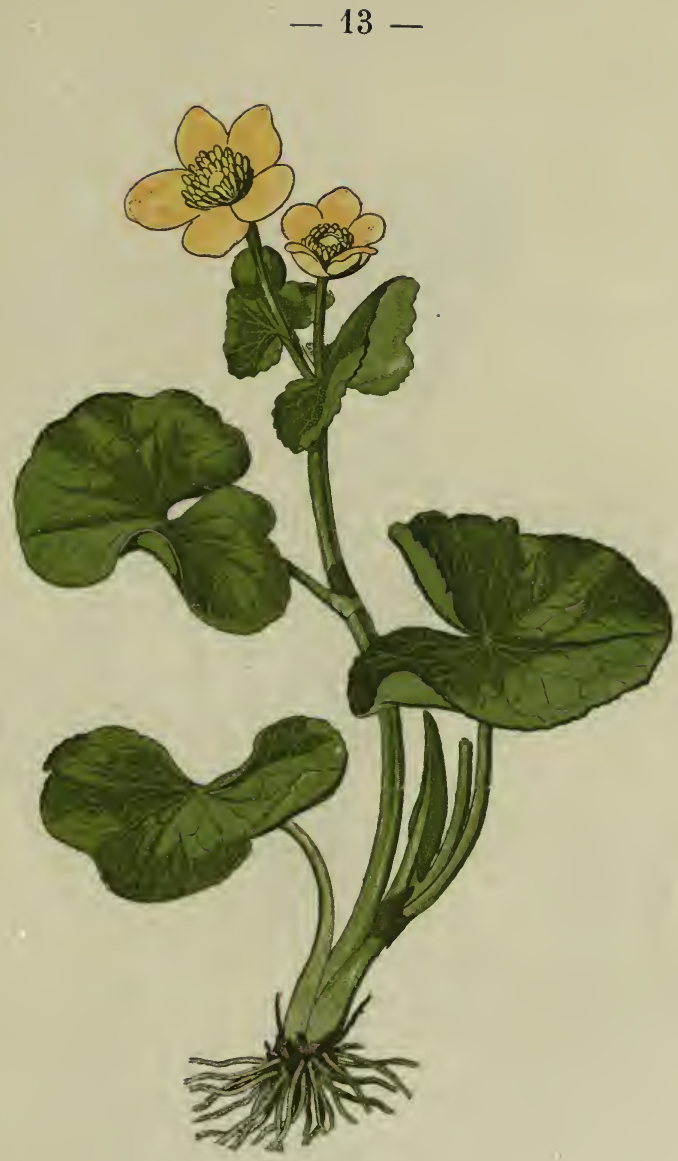

Marsh Marigold.

Caltha palustris.

- Ranunculacez. - 
$-14-$

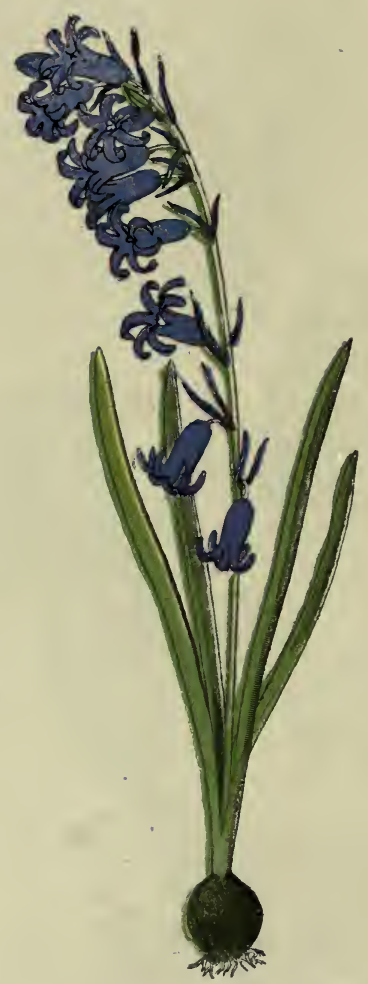

Wild Hyacinth. Blue-bell.

Scilla nutans.

- Liliacede. - 
with triangular leaves and rooting stems. It occurs only in Forfarshire, and is very rare.

The name is derived from the Greek, Kalathos, a cup, in allusion to the form of the flower.

\section{Wild Hyacinth, or Blue-Bell (Scilla nutans).}

After the daisy, buttercup and primrose, few wild flowers are better known than the Blue-bell or Wild Hyacinth. In the very earliest days of spring its leaves break through the earth and lay in rosette fashion close to the surface, leaving a circular tube through which the spike of pale unopened buds soon arises. A few premature individuals may be seen in full flower at quite an early date ; but it is not until spring is fully and fairly with us that we can look through the woods under the trees and see millions of them swaying like a blue mist; or, as Tennyson has finely and truly worded it, "that seem the heavens upbreaking through the earth." This must not be confounded with the Blue-bell of Scotland, which is Campanula rotundifolia (see page 78 ).

If we dig up an entire specimen we shall find that, like the hyacinth of the florist, its foundation is a roundish bulb, in this case somewhat less than an inch in diameter at its stoutest part. The leaves have parallel sides, or, as the botanist would say, they are linear; and before the plant has done flowering they have reached the length of a foot or more, whilst the flower-stalk is nearly as long again. Before the flowers open the buds are all erect, but these gradually assume a drooping attitude; though when the seeds are ripening the capsule again becomes erect.

The flower is an elongated bell, showing no distinction between calyx and corolla ; it is therefore called a perianth. It consists of six floral leaves, joined together at their bases, the free portions curling back and disclosing the six yellow 
anthers, which are attached to the sides of the perianth, one to each segment. The ovary is surmounted by the thread-like style, ending in a minute stigma. The capsule is three-celled, and when the seeds are ripe each cell splits down the side to release the shining black seeds.

The Genus Scilla belongs to the Natural Order Liliaceæ; its name is classical, and probably derived from the Greek Skyllo, to annoy, in allusion to the bulbs being poisonous. There are two other native species :-

The Vernal Squill (S. vernalis). Flower-scapes, one or two, not so long as leaves. Like $S$. nutans, it has a couple of long bracts at the base of the pedicels, as the short stalks are called, which connect the flowers with the tall scape. This is a rare plant, occurring only in rocky pastures near the west coast from Flint to Devon ; also Ayr and Berwick to Shetland, and in the E. and N.E. of Ireland. April and May.

The Autumnal Squill ( $S$. autumnalis) throws up several flower-scapes before the leaves. Flowers, reddish-purple, not drooping, but spreading or erect; July to September in dry pastures from Gloucester to Cornwall, from Middlesex to Kent. No bracts.

\section{The Cackoo-pint (Arum maculatum).}

Lords-and-Ladies, Cuckoo-pintle, Priest's-pintle, Calves-foot, Starchwort, Ramp, and Wake-robin are also names by which this very familiar spring-plant is known in different localities. Its appearance is remarkable, and its structure no less interesting. About a foot below the surface of woods and hedgebanks is the tuberous rootstock, from which arise above ground in March the handsome arrow-shaped leaves, more or less spotted with red or purple. From the midst of these leaves in April rises the flowerstalk, bearing an enormous pale-green rolled-up bract-leaf, of similar nature to the small thin bract we observed at the base of the pedicels in Scilla, but larger than the ordinary leaves. It 


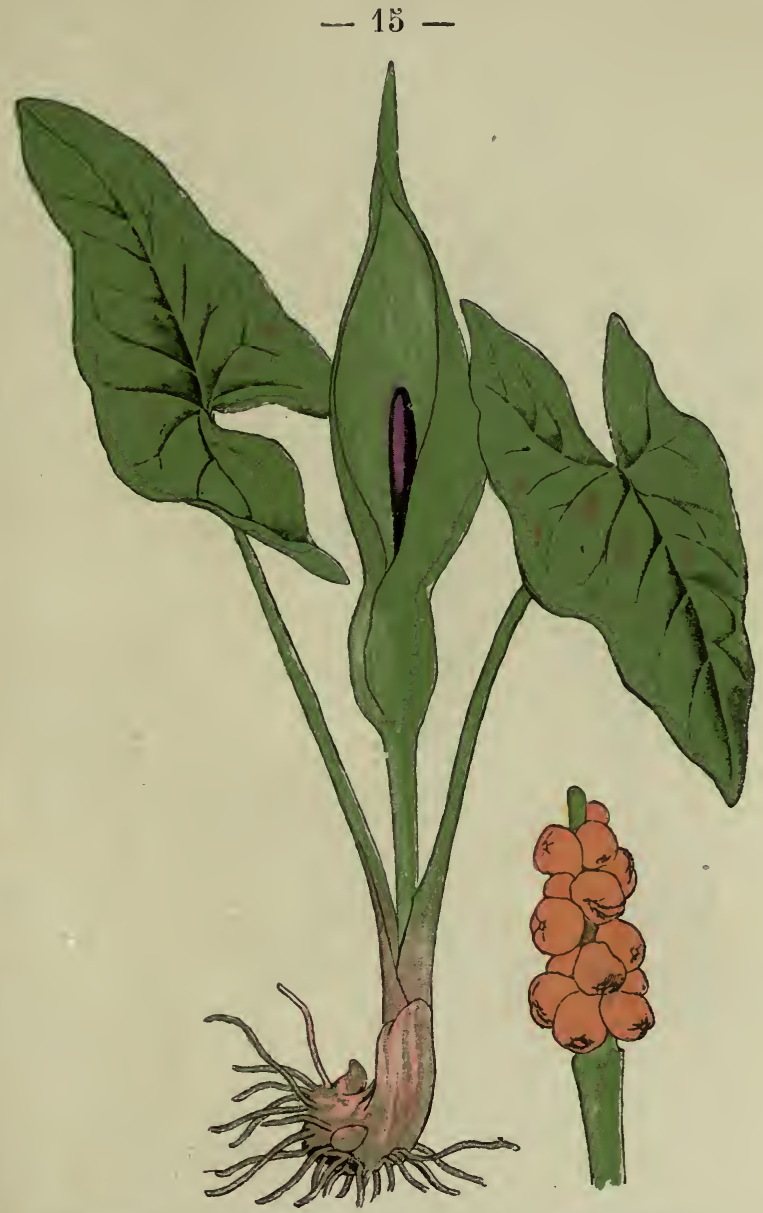

Cuckoo-pint, Lords and Ladies, Wake Robin. Arum maculatum.

- AROIDEF. - 
$-16-$

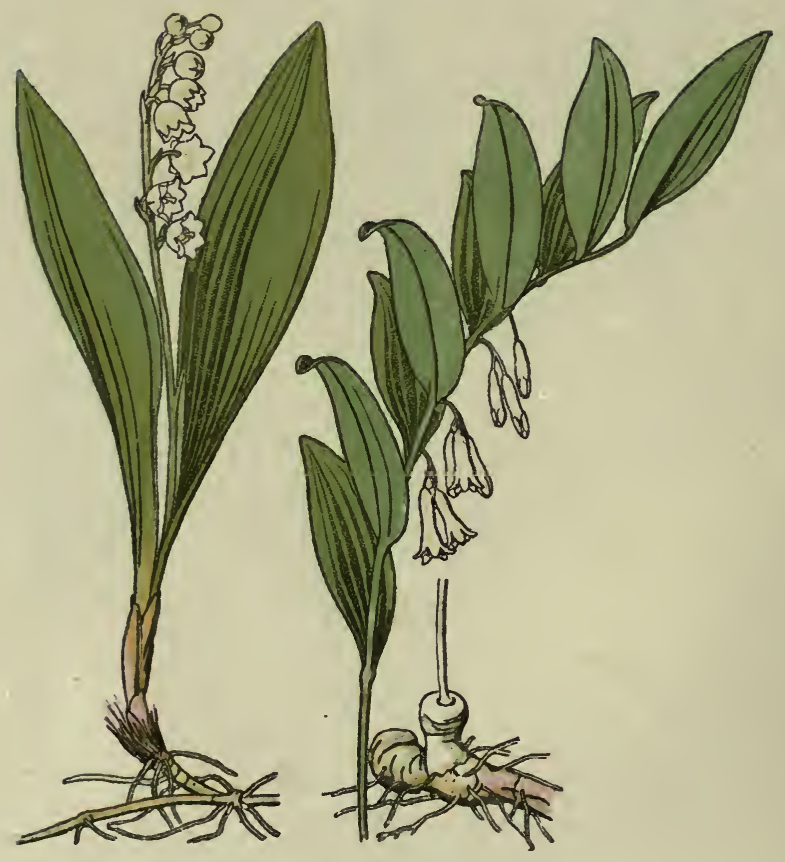

Lily of the Valley. Convallaria majalis.
Solomon's Seal.

Polygonatum multiflorum. 
unrolls and then resemb!es a monk's-cowl, and also discloses a purplish cylindric column. The green envelope is called a spathe, and must not be taken for a flower. The flowers are there in great number, but they are small and arranged round the lower part of the central column (spadix). The lower third of the spathe is marked off from the rest by a slight constriction, and if with a sharp knife we slice off the front portion of this part we shall there find the flowers in four series.

Proceeding downwards we first find a ring of abortive stamens, each ending in a long, deflexed hair. A little lower is a series of perfect anthers, and below these a similar group of pistils, the topmost row of which consists of abortive organs with hair-like processes. Small flies are attracted to the spathe by the carrion-like colour and odour of the spadix, and explore the lower premises. The hairs allow easy descent, but prevent return. If the flies have already been in an Arum flower they bring with them pollen on wings and feet, and find the stigmas ripe to receive it. When these are no longer fit for fertilization the anthers open and discharge their pollen in a shower on the insects; the stigmas secrete honey as a reward to the imprisoned flies, and the upper series of hairs shrivel up and set the insects free to carry their pollen to another Arum.

The spathe and spadix wither, but the ovaries develop into codlin-shaped pale scarlet berries. This species is plentiful throughout the country. There is one other species, Arum ilalicum, found locally from Cornwall to Sussex. It is larger and stouter in all respects; the upper part of the spathe bending over, and the spadix yellow. Flowers in June.

\section{Lily of the Yalley (Convallaria majalis). Solomon's Seal (Polygonatum multiflorum).}

These plants are very familiar as garden flowers; they are nevertheless natives, though by no means common in the wild 
state. Both are characterized by having thick creeping rootstocks. Convallaria differs from Polygonatum in having no stem ; the two or three leaves springing direct from the rootstock. The flower is a bell-shaped perianth, the mouth split into six recurved lobes. Stamens six, attached to the base of the perianth, around the ovary, which ultimately becomes a globose red berry. It is much more widely distributed than Polygonatum. In woods; flowers May and June. Name from the Latin Convallis, a valley. The only British species.

Solomon's Seal has a distinct arching stem, with alternate erect leaves. The flower-stalks spring from the axils of the leaves, and bear from two to five greenish-white flowers each. The berries that succeed the flowers are blue-black. The flowers are similarly formed to the last-mentioned, but longer, more tubular, and the lobes not turned back. The stamens are attached about half-way down the perianth. There are two other native species, both rare.

The Angular Solomon's Seal ( $P$. officinale), much smaller than the last, the flowers mostly occurring singly, larger and greener. Wooded limestone cliffs, May and June.

Narrow-leaved Solomon's Seal ( $P$. verticillatum), with leaves in whorls around the angled stem. Wooded glens, Northumberland, Perth and Forfar only. June and July ; very rare.

Name from the Greek, polys, many, and gonatos, a knee or angle, in allusion to the many nodes.

\section{Hawthorn (Cratcegus oxyacantha).}

The Hawthorn, May, or Whitethorn, is too well known to require much description. Its more familiar appearance is as a hedge-forming shrub, when it is not allowed to have any natural form, but in the woodlands it becomes a round-headed tree, and when fully in flower looks like a monstrous snow-ball on a stalk. The tyro in botany can tell almost with a glance 


\section{$-17-$}

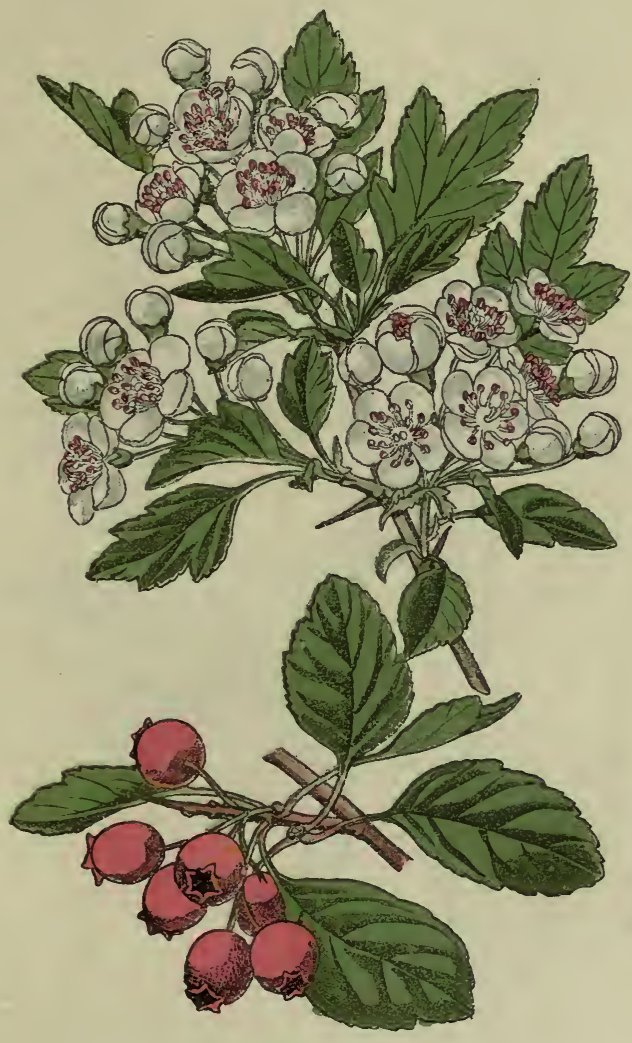

May or Hawthorn.

Cratægus oxyacantha.

- ROSACEA. - 
$-18-$

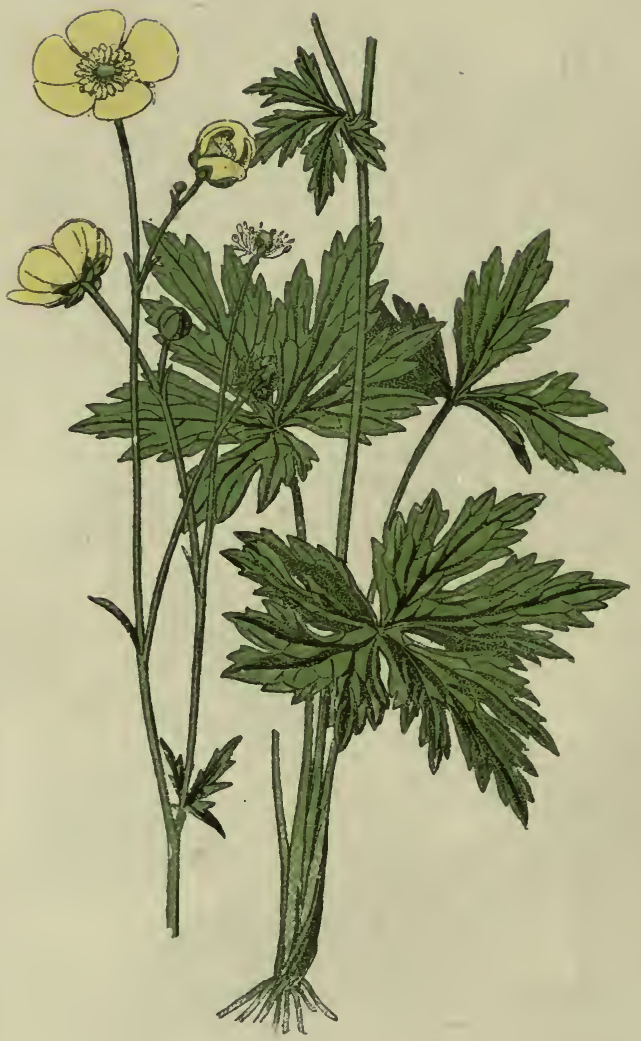

Buttercup.

Ranunculus acris.

- Ranunculaces. - 
at its beautiful flowers that it is a member of the great order of Roses, and not distantly removed from the apple section of that order. The calyx-tube adheres to the ovary, and the five petals are inserted at the mouth of the calyx. The stamens are numerous ; the styles one, two, or three, corresponding with the number of carpels. In the fruit these are covered by the red, fleshy coat in which the bony cells are enveloped, and which is valued as a food by birds in autumn and winter.

May and June are the usual months for flowering, but occasionally it is in blossom at the end of April. Though the characteristic odour from these flowers is sweet, now and then a tree will be found whose every flower gives out a distinctly fishy flavour that is far from pleasant; often, too, it may be found with pink or crimson blossoms. This is the only British species. The name is from the Greek, Kratos, strength, in allusion to the hardness of its wood.

\section{Buttercup (Ranunculus acris).}

There are three species of Ranunculus to which the name of Buttercup is applied impartially; but the one to which it most properly belongs is the Bulbous Crowfoot ( $R$. bulbosus), in which the cup-shape is more perfect than in the others. We have already dealt with the general characters of the genus in describing the Lesser Celandine : here we will glance only at the specific differences between this and the other buttercupspecies of Ranunculus or Crowfoot.

I. Ranunculus acris is the Upright Crowfoot. The rootstock is straight and erect. The lower leaves are divided into wedgeshaped segments, which are again much cut up-the upper leaves less intricately so. The petals are broader than in the Celandine, and fewer-usually five, more or less flat when fully expanded. Flower-stalk not furrowed; sepals spreading. Stem one to three feet high. Meadows and pastures everywhere, June and July. 
II. R. repens, the Creeping Crowfoot. Rootstock stout, stem declining, with long runners. Flower-stalk furrowed, sepals spreading, but petals less so than in $R$. acris. Stem one to two feet. Pastures and waste places, too frequent, May to August.

III. R. bulbosus, Bulbous Crowfoot. Stem erect, half to one foot, greatly swollen at base : no runners. Flower-stalk furrowed, sepals turned back, nearly or quite touching the stalk; petals not spreading, but cup-shaped. Meadows everywhere, April to July.

The name Ranunculus is derived from the Latin, Rana, a frog, in allusion to the damp meadows and the ponds where certain species are to be found in company with frogs.

\section{Wall Barley (Hordeum murinum).}

In all waste places on a sandy soil, near towns and villages especially, the Wall Barley, Mouse Barley, Barley-grass, or Way-bent flourishes. At the base of walls is a favourite post for it, where it collects dust, and generally contributes to an appearance of untidiness. Its bristly spike is well known to the schoolboy, who breaks it off and inserts the stem end in the cuff of his shirt-sleeve, whence it works its way automatically to the shoulder. If the spike is cut across its length, the spikelets of which it is made up mav be separated and examined with a lens. It will then be seen that the spikelets are borne in threes side by side, but that only the central one is a perfect one, the lateral ones being barren. Taking this central one from the others, we find two outer inflated scales (glumes) embracing two other scales, one of which, with the cleft tip and two keels on the back, is the pale, the other, ending in a long awn, is the flowering glume, within which is the ovary, surmounted by its two feathery stigmas. From beneath the ovary spring the three stamens and two minute scales, called 


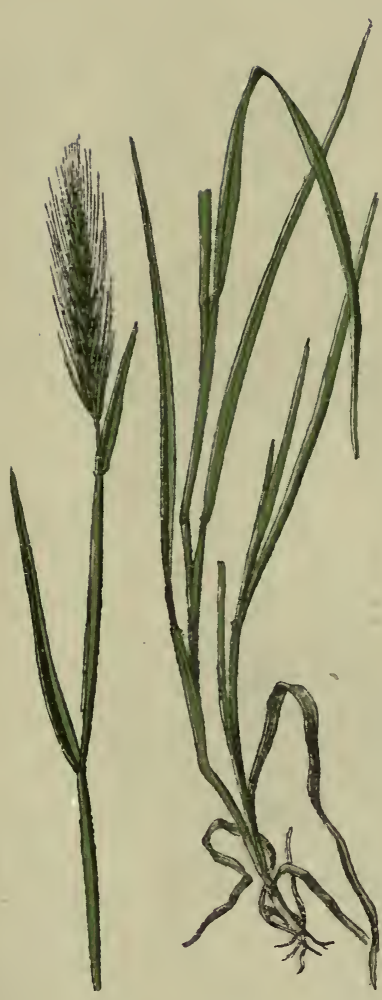

Wall Barley.

Hordeum murinum.

- Graminef. -

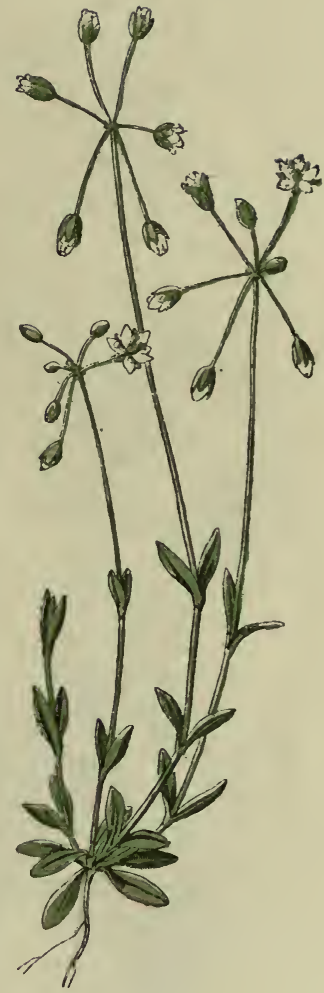

Jagged Chickweed. Holosteum umbellatum. - Caryophyllee. - 


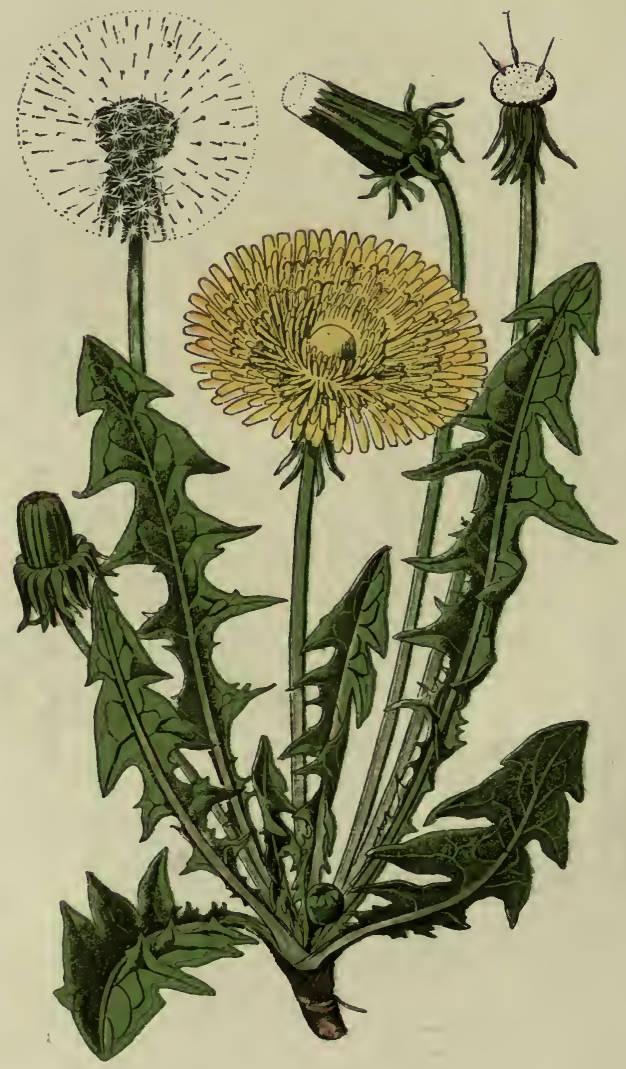

Dandelion.

Taraxacum officinale. 
lodicules, which answer to the perianth in ordinary flowers. It would be well to quite master this arrangement by dissection, for all grass flowers are built on a similar plan.

Hordeum is the old Latin name for barley. Flowers June and July.

\section{Jagged Chickweed (Holosteum umbellatum).}

This is a very rare plant, occurring only on old walls about Norwich, Bury and Eye. The rambler in those localities might pass it by as a variety of the vulgar Chickweed, to which, however, it is distantly related. The small white, flowers are arranged in an umbellate manner, though not forming a true umbel. Whilst flowering the long pedicels are erect, but after flowering they hang down; after fruiting they become erect again. Flowers April and May.

Name derived from the Greek olos, all, and osteon, bone, but Artemus Ward would have said it was "wrote sarcastick," for there is nothing suggestive of bones in so soft a plant.

\section{Dandelion (Taraxacum officinale).}

Everyone thinks he knows the Dandelion when he sees it and probably he does; but often when he sees a Hawkbit he believes it to be a Dandelion. We may not like to find the Dandelion taking possession of our lawn, but we should regret to miss it from the odd corners by the fence and the roadside. It is a flower of three seasons, for it blooms continuously from March to October, and it is no unusual thing to see its golden flower in winter.

This is a Composite flower, like the Daisy, but whereas the Daisy head was seen to be made up of a host of tubular flowers, with a single outer row of ligulate, or strap-shaped ones, those of the Dandelion are all ligulate. It therefore stands 
as a representative of the second series of Composite genera. The plant has no proper stem, the leaves springing directly from the long, thick root. From their midst arise the flowerheads on their hollow stalks. The floral envelope (involucre) consists of a double row of scales (bracts), the inner long, the outer shorter. The outer are turned back and clasp the stalk, the inner erect. Take off a single floret and examine with a lens. It will be seen that each is a perfect flower, containing both anthers and stigmas. The ovary is crowned by the corolla, which is invested by a pafpus of soft white silky hairs. Within the corolla the five anthers unite to form a tube, in which is the style, which divides above into two stigmas. After fertilization the corollas wither, the inner bracts closing over them while the fruits grow. Then the bracts open again, each pappus spreads into a parachute, and the whole of them constitute the fluffy ball by which children feign to tell the time. A light wind detaches them, and they float off to disperse the seeds far and wide. The only British species.

The name is believed to be derived from two Greek words, Taraxos, disorder, and akos, remedy: in allusion to its wellknown medicinal qualities as an alterative.

\section{The Bugle (Ajuga reptans), and}

\section{The Forget-me-not (Myosotis palustris).}

The Common Bugle meets one from April to July in wood and field, and on the waste places by the roadside. It is a creeping plant, runners being sent out from the short stout rootstock, and these rooting send up flowering stems from $\frac{1}{2}$ to I foot in height. The leaves from the root are stalked; those from the stem are not. The flowers and the upper bract are dull purple in colour. The flowers are peculiarly fashioned in what is botanically termed a labiate manner : that is to say, the 


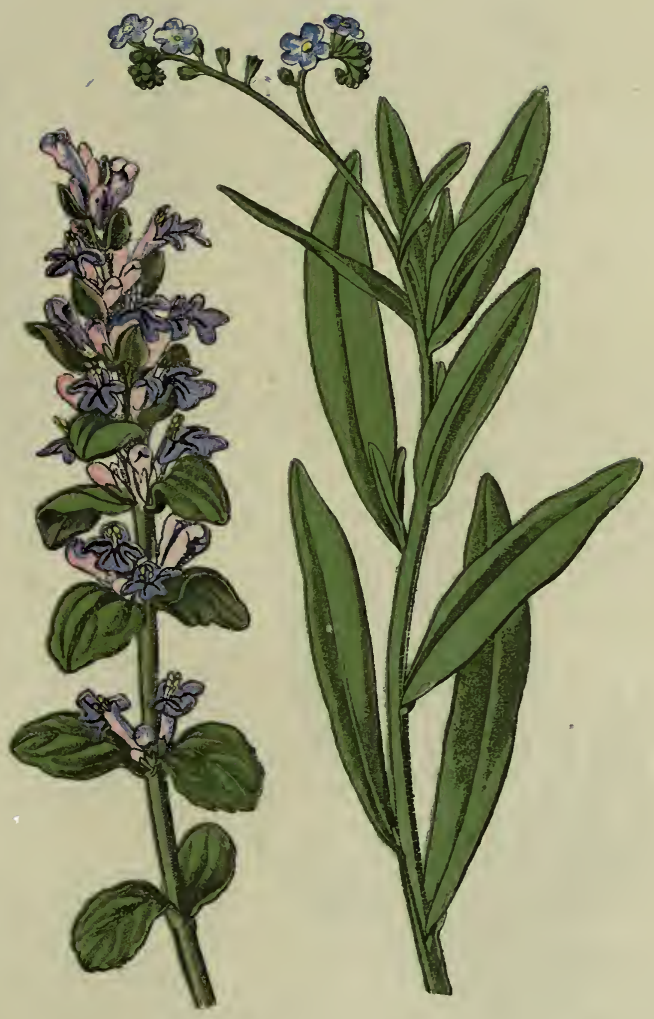

Bugle.

Ajuga reptans.

- Libiate. -
Forget-me-not. Myosotis palustris.

- Boraginea. - 

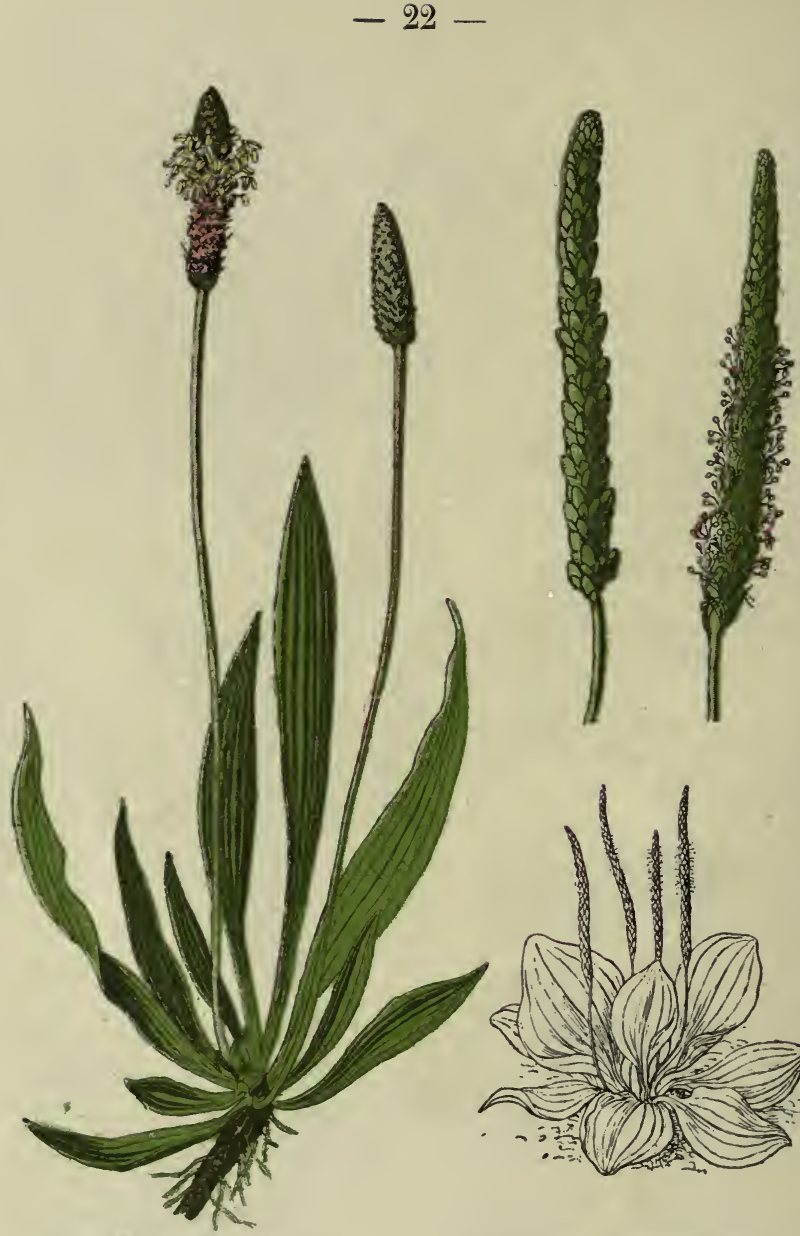

Ribwort Plantain. Plantago lanceolata.

Greater Plantain. Plantago major. 
five petals of the corolla are united to form a somewhat bellshaped flower, the mouth of which is divided into two unequal lips. The upper lip is two-lobed, the lower three-lobed. The upper usually acts as a roof to shelter the stamens and stigmas, the lower as a platform upon which insects may alight when they come to seek honey and to fertilize the flower. In the present species the anthers and stigmas project beyond the upper lip, which is very short; but they are protected by the overhanging lower bract of the flower above. There are interesting facts in connection with the fertilization of these labiate flowers, which, however, we must leave for a couple of pages. It is characteristic of the Labiatæ that the stems are square, the leaves opposite, the corolla bilabiate, the stamens less in number than the lobes of the corolla.

The Forget-me-not is so well known that with our limited space we will be content with noting that its flowers are similar in structure to those of the Lungwort (page 9), though the tube is shorter. Like Pulmonaria, it is a plant of the order Boragineæ, genus Myosotis. There are six British species. Name, from two Greak words signifying mouse-ear, in allusion to the shape of the leaves.

\section{The Greater Plantain (Plantago major), and The Ribwort Plantain ( $P$. lanceolata).}

These are among the despised of our wild-flowers, weeds among weeds. They are considered of interest only to the keeper of cage-birds, by whose pets the ripe fruit-stalks are much appreciated. But if we knew the plants better we should appreciate them more. There must be something worthy of respect in a plant that has contrived to get itself so taken throughout the world that it is known wherever Europeans have been, and is called the White-man's Foot. The leaves of the genus are characterized by having strongly developed parallel ribs on the under surface. 
There is no stem, the leaves all springing from the stout rootstock. The flowers are borne on tall spikes which spring from the axils of the leaves. Each blossom consists of four persistent sepals, a salver-shaped corolla with four lobes, between which are fixed the four stamens surrounding the long, simple and hairy style. There are five British species, of which we figure two. The name Plantago is the classic Latin one, from which the English has been evolved.

I. The Greater Plantain ( $P$. major) has very broad leaves and broad, short leafstalks. Stamens short, anthers purple. Seeds black and rough. Pastures and roadsides, May to September.

II. Hoary Plantain ( $P$. media): leaves not so broad, flower-scape shorter. Stamens long, anthers whitish. Seeds brown, rough. Pastures and waste places in a dry soil, June to October. Plant more or less covered with short hairs.

III. Ribwort Plantain ( $P$. Lanceoluta): as the scientific name implies, the leaves are lance-sliaped, long and narrow. The flower-scape is deeply furrowed, the flower-spike short. Stamens long, white. Seeds black, shining. Pastures and heaths, May to October.

IV. Seaside Plantain ( $P$. maritima). Rootstock branched, crown woolly. Leaves narrower than the last, margins more parallel, ribs weak. Stamens pale yellow. Seeds brown, slightly winged at end. Pastures, salt-marshes and rocks by the sea, June to September.

V. Buck's-horn Plantain ( $P$. coronopus). Leaves narrow, linear, divided, or deeply-toothed, suggesting the popular name; ribbed, hairy. Stamens pale yellow. Seeds pale brown. Poor gravelly soils, chiefly near coast. June to August.

\section{Meadow Sage (Salvia pratensis).}

In speaking of the Bugle on page 22 we promised to say more of Labiate flowers further on. Salvia is a labiate, and of similar construction to Ajuga. S. pratensis is a rare plant, found only in Cornwall, Kent, and Oxford, from June to August. The soft wrinkled leaves have the edges cut into convex teeth (crenate). The flowers are large and bright blue; they are borne in whorls, usually of four or five flcwers, on a tall spike. There is a more frequent species, the Wild Sage or Clary $(S$. verbenaca), found in dry pastures all over the kingdom south of Ross-shire from June to September. It is similar in habit to $S$. 

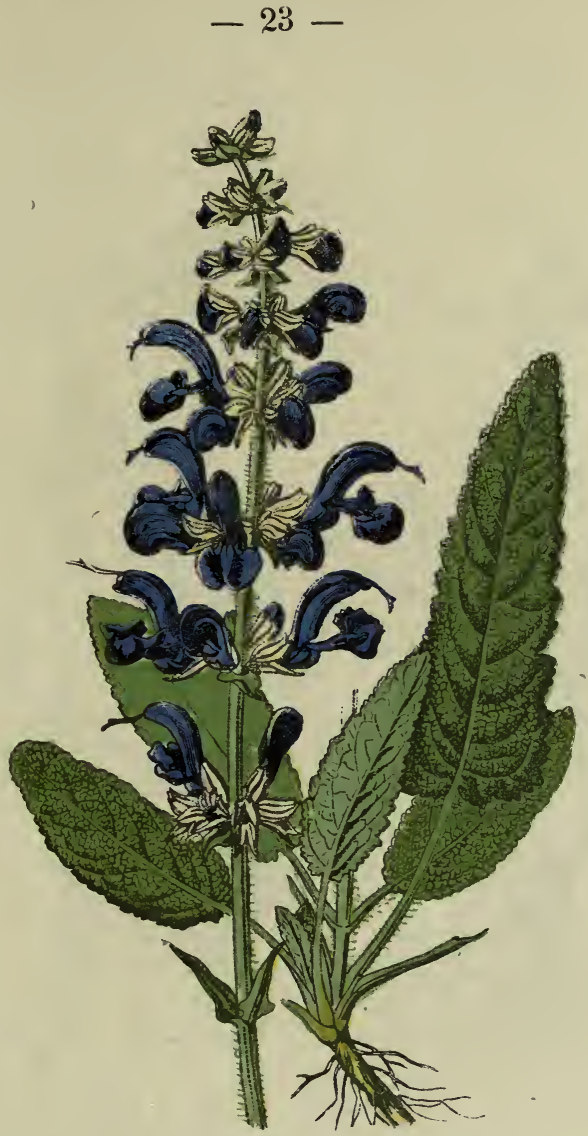

Meadow Sage.

Salvia pratensis.

- IABiAT F. - 


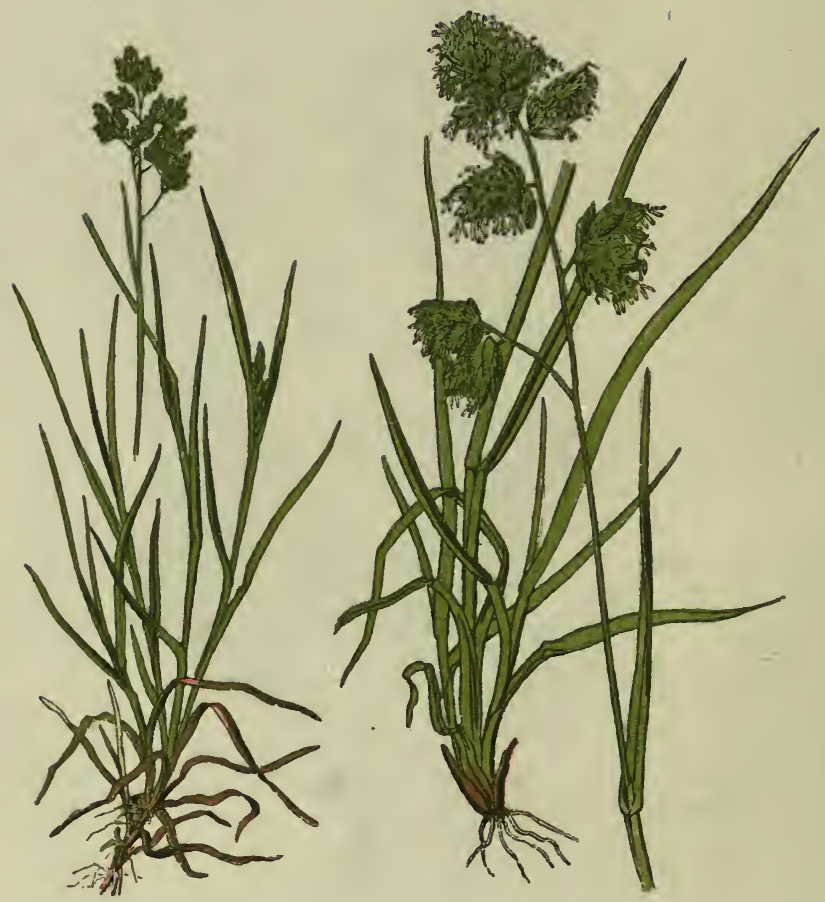

Annual Meadow-Grass. Poa annua.
Cock'sfoot-grass. Dactylis glomerata. 
pratensis, but smaller, with the flowers more inclined to purple. The Sage of the kitchen-garden is S. officinalis; not a native plant. The name Salvia is from the Latin Salvo, to save or heal, from its former great repute in medicine.

Most labiate flowers produce honey from the base of the ovary; and this, of course, is a distinct bribe to insects to visit them. It would not be an economical arrangement for a flower to provide honey for all comers without the plant getting a quid pro quo: we therefore find all sorts of "dodges" to ensure a service being done by the honey-seeker. As we have shown in the Bugle, the anther and stigma occupy the arch of the upper lip. As a rule the ripe anthers first occupy the foremost position, so that if a bee alights on the lower lip and pushes into the corolla for the honey his hairy back will brush off the pollen from the anthers. After the honey is shed the stigmas come forward and occupy the former position of the anthers. Should a bee that has got dusted with pollen at an earlier flower now pay a visit the stigmas will collect some pollen from his back and the ovules become fertilized. This is the general plan in the order Labiatæ, but there are modifications in each genus.

\section{Annual Meadow-grass (Poa annua), and Cock's-foot-grass (Dactylis glomerata).}

In describing the Wall Barley we gave a general idea of the structure of grass flowers, and those of $P o a$ are very similar to those of Hordeum; but the flower-cluster (inflorescence) is very different. In Hordeum (which see) this is a spike, bearing many three-flowered spikelets on each side. In $P o a$ it is more branched and diffuse, and is called a panicle. In $P$. anmua the branches grow two together, and are branched again. The spikelets are not awned as in Hordeum. There are eight British species of Poa, which, however, we have not space to 
describe. The name is Greek, and signifies fodder. All the species are perennial, with the exception of $P$. annua, which is an annual, as the name indicates. It flowers from April to September, and abounds in meadows, pastures and by roadsides.

The Cock's-foot-grass (Dactylis glomerata) is an ingredient of most pastures, and one of our most familiar grasses. Its long stout stem creeps for a distance, then rises very erectly and gives off horizontal flowering branches. The violet-tinted spikelets are gathered into dense one-sided clusters. Each spikelet contains three or four flowers, which are supposed to be arranged after the fashion of fingers on a hand, whence the Greek name Daktulos, fingers. Each flowering glume ends in a short awn-like point. This is the only British species. It is generally distributed, and will be found in waste places as well as pastures, flowering in June and July. The whole plant is rough to the touch. The leaves are long, flat and keeled.

\section{Cat's-tail, or Timothy-grass (Phleum pratense), and Yernal-grass (Anthoxanthum odoratum).}

Timothy is one of the most valuable of our grasses, and forms an important portion of the hay crop, from the fact that it is one of the earliest and most abundant species. The inflorescence is a crowded spike, reminding one somewhat of a miniature reproduction of the Reed-mace (Typha). The spikelets are one-flowered. The outer glumes are boat-shaped, with a stout green keel, fringed with stiff hairs. The flowering glume is glassy, and entirely included within the outer ones, from which, however, the long stamens and feathery stigmas protrude. The anthers are yellow and purple. The plant is perennial, and flowers from June to September. The name Phleum is the classic Greek one for the plant. The figure represents 


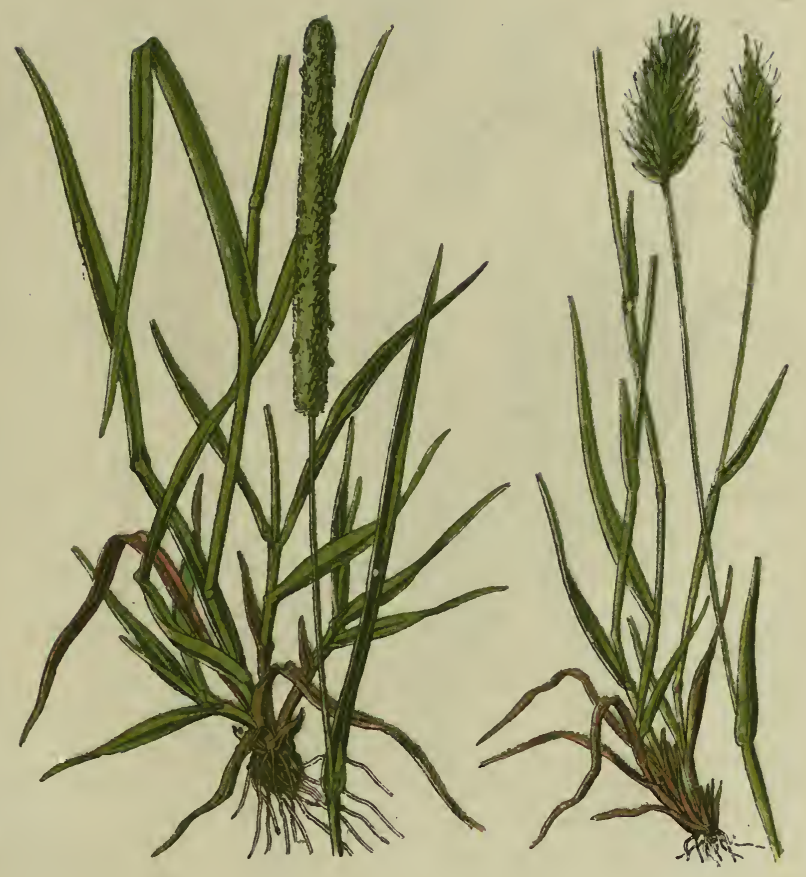

Timothy-grass.

Phleum pratense.
Vernal-grass.

Anthoxanthum odoratum. 


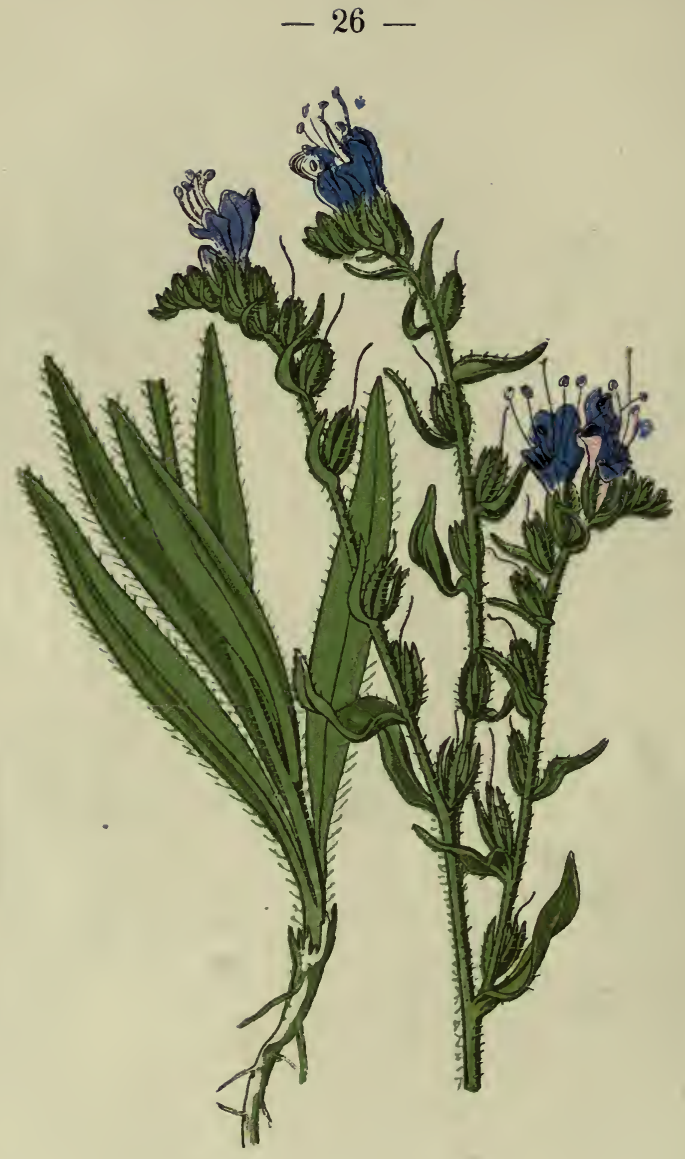

Viper's Bugloss.

Echium vulgare.

- Boraginea. - 
the spike after the anthers have passed their prime; at an earlier period these stand out well from the glumes, and give a very light appearance to the spike. There are three other native species, but they are all more or less local.

The Sweet Vernal-grass is singular among grasses in the fact that it possesses but two stamens. The panicle is spikelike, with short branches. The spikelets are one-flowered. The outer glumes are four in number, one flowering glume, a pale, but no lodicules. In the Linnæan system plants were classified according to the number of their stamens and pistils, and the artificiality of it was strikingly shown when this plant had to be widely separated from all other grasses, because it was one stamen short, though agreeing with them in all other essentials. The species is abundant in most meadows, and were it absent one of the charms of the hay harvest would be gone also; for this is the grass that gives the characteristic odour to ripe new-mown hay. It flowers in May and June. The name is from two Greek words, signifying yellow blossoms

\section{Yiper's Bugloss (Echium vulgare).}

Our artist has chosen to delineate a specimen of this striking plant that has passed its prime in a flowering sense. To our mind the Viper's Bugloss is prettiest when only one or two flowers are open on each cyme. The recurved cymes are then very short, and the unopened flowers packed closely together. As in Lungwort (p. 9), the unopened corollas are purplish-red in colour, when opened bright blue. After flowering, the cymes lengthen until they are as long as shown in our illustration. The parts of the flower, it will be seen, are in fives : calyx five-parted, tubular corolla with five-lobed "limb," as the free portion is called, stamens five, stigma two-lobed. The lobes of the corolla are unequal, and one of the stamens is shorter than the other four, which protrude from the corolla considerably; in fact, they serve as a platform upon which 
insects alight. When the flower opens the anthers are ripe and shed their pollen, so that bees or other insects alighting are sure to get their under surface dusted with it. At this period the pistil is short and immature, so that it cannot be fertilized by its own pollen; but as the pollen disappears the pistil lengthens, until its stigmas are in the position where they are bound to receive pollen brought on the under surface of a visiting insect. The leaves are strap-shaped, long, and rough with hairs.

Much fault is found with scientific names on account of their uncouthness and obscurity. But they are mostly derived from Greek and Latin roots, and reflect some peculiarity of the plant; whereas many of the English or Folk-names are most arbitrary, and require much explaining, which is sometimes not easily done. "Viper's Bugloss" is a puzzle, and authors have pretended to see likenesses to a viper in the markings of the stem, the shape of the flower and of the seeds; others have taken shelter behind Dioscorides, who said that a decoction of the plant was a protection from the effects of a viper's bite. If a man knew he was going to be bitten by a viper and took a certain dose of this plant beforehand he was all right! But the word bugloss seems a worse puzzle than the plant's connection with vipers. Most dictionaries will help to the extent of telling that bugloss is the name of a plant, and no more. The truth is, it is as Greek as any scientific name, being compounded of the words Bous, an ox, and glossa, a tongue, from its leaves being rough, like the tongue of an ox.

It is common on gravelly and chalky soils, flowering from June to August. It is rich in honey, so that it is much frequented of sweet-tongued insects. The name Echium is from the Greek Echis, a viper.

\section{Wild Strawberry (Fragaria vesca).}

Well known as the Wild Strawberry is, the Barren Strawberry (Potentilla fragariastrum) when flowering is often mis- 


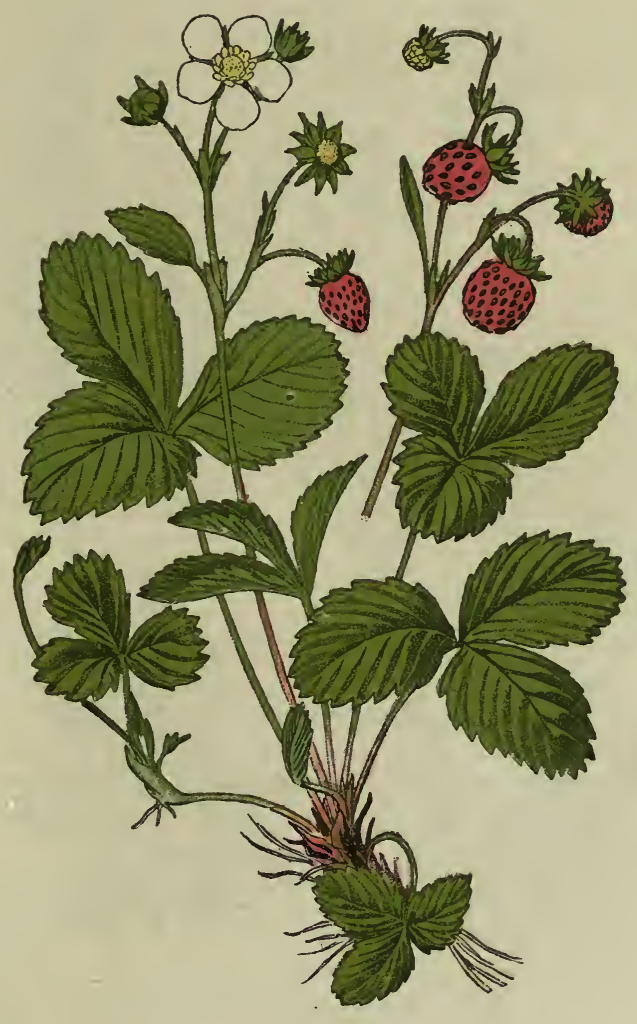

Wild Strawberry.

Fragaria vesca.

- ROSACEA. - 
$-28-$

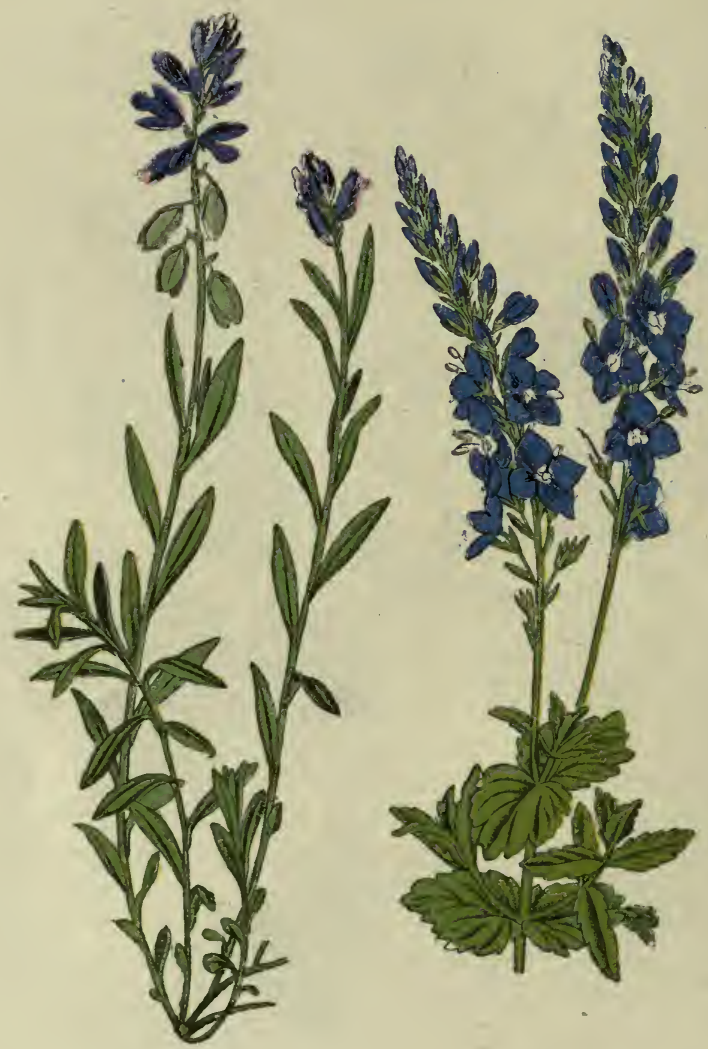

Milkwort.

Polygala vulgaris.

- Polygalex. -
Germander Speedwell.

Veronica chamædrys.

- Scrophularine 
taken for it. The general resemblance is fairly close, but a botanist can distinguish each at a glance. In each the leaves are divided into three leaflets, the flowers are white and fiveparted; but in $F$. vesca the upper side of the leaf is channelled with sunken nerve-lines, whilst in $P$. fragariastrum it is smooth. The real strawberry sends off runners with young rooting plants; the false does not. When the fruit is formed there is no longer danger of confounding the two species, for the false plant entirely lacks the fleshiness of the true. The fruit of the Strawberry is a compound one, consisting of a large number of achenes scattered over the enlarged and succulent top (receptacle) of the flower-stalk, beneath which are spread out the persistent green calyx-lobes.

It is a widely distributed species, flowering from April to June, and found on shady banks, and in woods. The name Fragaria is from the Latin fragrans, fragrant, and has reference to the perfumed fruit.

\section{Milkwort (Polygala vulgaris), and}

\section{Germander Speedwell (Veronica chamadrys).}

Nestling closely among the grass of heaths and dry pastures, the Milkwort, though commonly and profusely distributed, is not a well-known plant. It is only a few inches in height, and scarcely noticeable when not in flower. The narrow, tough leaves are scattered alternately on the stem. The broad inner two of the five sepals are coloured purple, and the corolla may be the same hue, or pink, blue, white or lilac. The structure of the flower is very curious, and should be carefully noted by aid of the pocket-lens. The stamens cohere, and the corolla is attached to the sheath thus formed. The pistil has a protecting hood over it, obviously with reference to the visits of insects ; but the flower is also self-fertile. When the fruit is formed the sepals turn green. The name of the genus is 
derived from two Greek words, polus and gala, meaning much milk, from an ancient notion that cows eating this plant were enabled to give a greatly increased supply of milk.

There are two other British species:-

I. Proliferous Milkwort ( $P$. calcarea), branches rooting, and giving rise to new plants. Inner sepals broader and longer. Dry soils in south and south-east of England.

II. Bitter Milkwort ( $P$. amara), much smaller in all respects than the others; the inner sepals are narrow, and the leaves form a rosette. Very rare. Found only on the margins of rills in Teasdale, and Wye Down, Kent. They all flower from June to August.

The Germander Speedwell (Veronica chamadrys) is the representative of a genus which includes sixteen native species, most of them with bright blue flowers of a particular form. The corolla is tubular for half its length, the upper portion divided into four spreading lobes, of which the upper and lower are usually broader than the lateral pair. The two stamens are attached within the corolla-tube just below the upper lobe, and the anthers and stigma protrude beyond the mouth of the tube. $V$. chamadrys grows to greatest advantage in a great mass on a sloping bank, where, in May and June, its intensely bright blue flowers are very attractive. It is a most disappointing flower to gather, for the corollas readily drop off, and the beauty of the "button-hole" has rapidly passed. A fine robust species, the Brooklime ( $V$. beccabunga), grows in bogs, ditches, and by the margins of streams, with stout stem and thick leaves; flowering from May to September.

\section{The Spurge Family (Euphorbia).}

The whole of the British species of Spurge have a singular character, which enables the tyro in botanical inatters to determine the genus at a glance, though he may not be so success- 

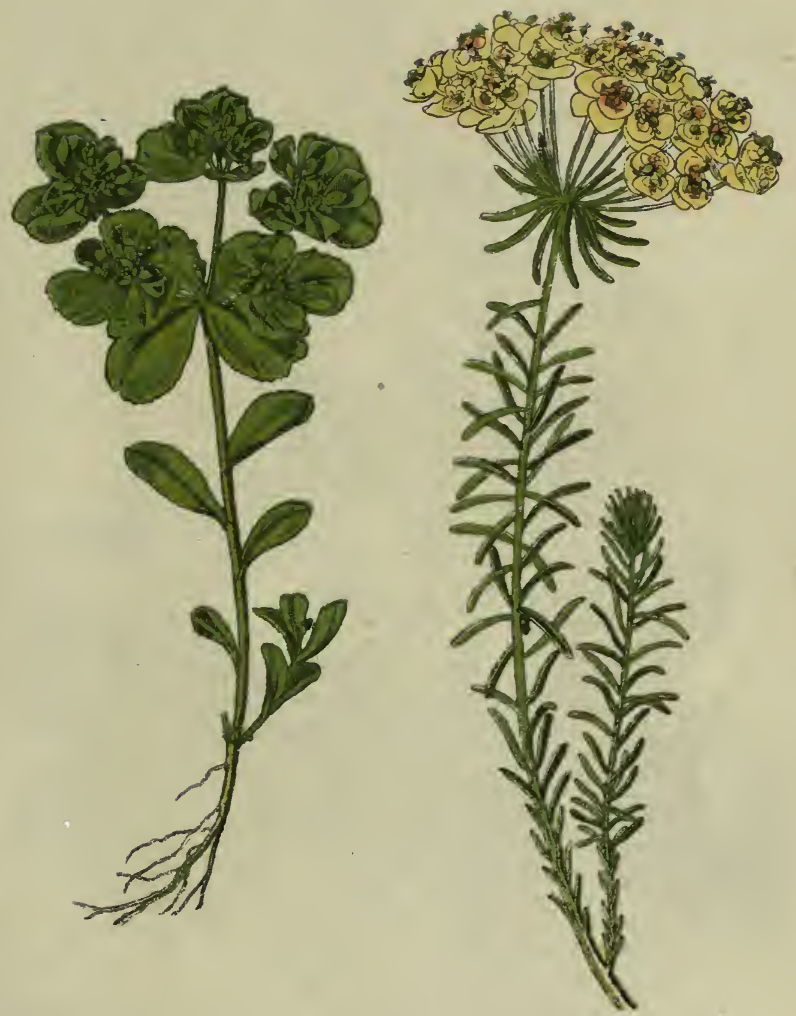

Sun Spurge.

Euphorbia helioscopia.
Cypress Spurge.

Euphorbia cyparissias. 
$-30-$

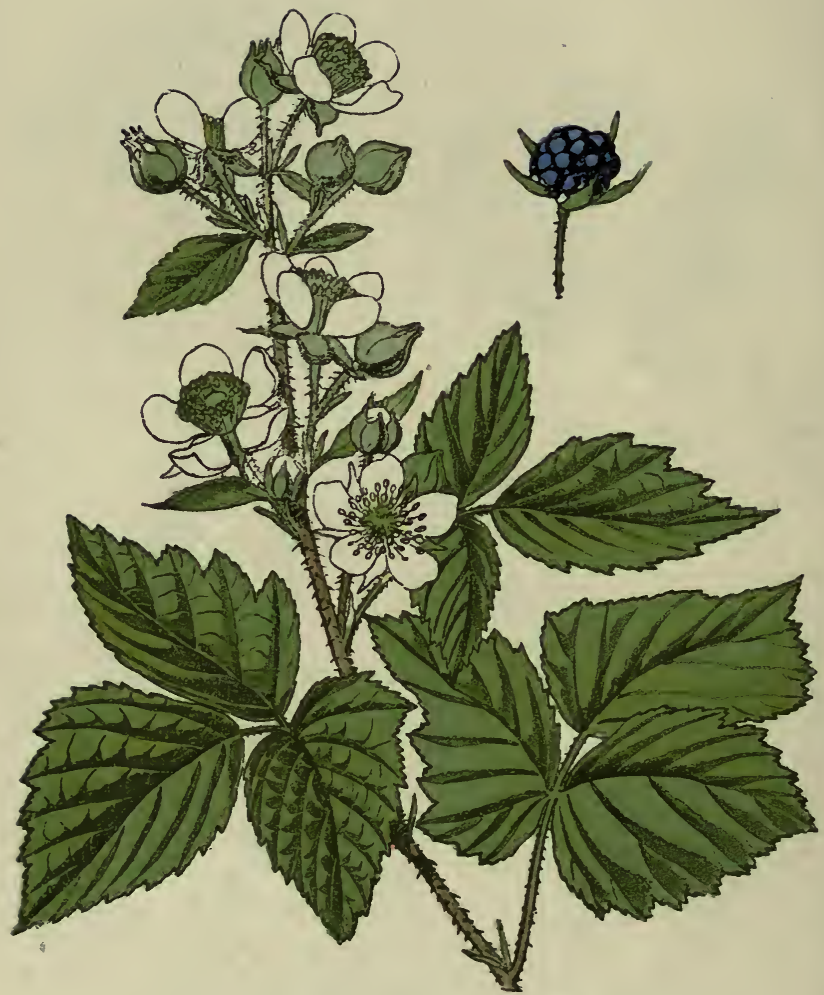

Dewberry.

Rubus cresius.

- ROSACE. E. - 
ful in distinguishing between the twelve or thirteen native species. This singularity is chiefly due to the colour and arrangement of their flowers. These possess neither sepals nor petals; instead, a number of unisexual flowers are wrapped in an involucre. An individual involucre of, say, the Sun Spurge, should be detached and examined with the aid of the pocket-lens. It will be seen to have four lobes, to each of which is attached an orbicular yellow gland. Within the involucre are several flowers, each consisting of a single stamen on a separate flower-stalk (note joint), and from the midst of these arises a single pistillate flower on a long, curved stalk. With slight variations this is the form of inflorescence which characterizes the whole genus. The British species may be briefly enumerated thus :-

I. Sun Spurge (E. helioscopia.) Annual herb with yellow green obovate leaves, the margin of upper half toothed. Milky juice used as a wart-cure. Waste places, June to October.

II. Broad-leaved Spurge (E. platyphyllos). Annual. Leaves broad, lance-shaped, sharp-pointed, toothed above middle. Fruit (capsule) warted. Fields and waste places from York southwards : rare. July to October.

III. Irish Spurge $(E$. hiberna). Perennial. Leaves thin, ovate, not toothed, tip blunt or notched; upper leaves heart-shaped. Glands of involucre purple, kidney-shaped. Hedges and thickets, rare; only in North Devon and South and West of Ireland. Flowers May and June. Juice used by salmon-poachers for poisoning rivers.

IV. Wood Spurge ( $E$. amygdaloides). Perennial, stout, red, shrubby. Leaves obovate, thick, tough, reddish, 2 to 3 inches long, hairy beneath, lower on short stalks. Involucral glands half-moon shaped, yellow. Woods and copses, chiefly on clay soils. Flowers March to May.

V. Petty Spurge (E. peplus). Annual. Leaves thin, broadly obovate, on short stalks, $\frac{3}{4}$ inch long. Involucral glands half-moon shaped (lunate), with long horns. Waste ground, market-gardens and flower-beds. July to November.

VI. Dwarf Spurge (E. exigua). Annual. Much branched. Leaves very narrow and stiff. Involucres small, almost stalkless. Involucral glands, rounded with two blunt-pointed horns. Fields, especially on light soil. July to October.

VII. Portland Spurge (E. portlandica). Perennial, tufted, many-branched stems. Leaves tough, obovate acute, spreading. Involucral glands, lunate, with two long horns. Sandy shores, on South and West coasts, and in Ireland. May to August. Rare.

VIII. Sea Spurge (E. paratias). Perennial, bushy, many-stemmed, stout, red- 
dish, woody below. Leaves narrow, concave, very thick, arranged in whorls, Points of involucral glands short. Sandy shores, July to October.

IX. Leafy-branched Spurge (E. esula). Perennial. Rootstock creeping. Stem slender. Leaves thin, narrow, sometimes toothed. Involucres small, on long stalks, glands lunate, with short straight horns. Woods and fields; Jersey, Forfar, Edinburgh, and Alnwick. July.

$\mathrm{X}$. Cypress Spurge (E. cyparissias). Perennial. Rootstock creeping. Leaves very narrow, not toothed. Woods, England, June and July.

XI. Caper Spurge (E. lathyris). Biennial. Stem short and stout, 3 to 4 feet second year. Leaves narrow, broader at base, opposite, alternate pairs placed at right angles to each other (decussate). Copses and woods, June and July. Fruit used as a condiment.

XII. Purple Spurge (E. peplis). Annual. Stems prostrate, purple, glaucous. Leaves oblong, heart-shaped, thick, on short stalks, with stipules, opposite. Glands oblong. Very rare. On sandy coasts, South Wales, Cornwall to Hants, and Waterford. July to September.

All the species have milky sap. Poisonous.

\section{Dewberry (Rubus casius). Plate 30.}

A sub-species of the Blackberry; too well known to require description.

\section{Honeysuckle (Lonicera periclymenum).}

The Woodbine or Common Honeysuckle is one of the most familiar of our wild flowers, and as great a favourite as any. It owes its popularity not only to the beauty of its flowers, but also to its strong sweet.odour, and in some measure to its graceful twining habit. The tough stem grows to a great length - ten to twenty feet in some cases-and always twines from" left to right. The egg-shaped leaves are attached in pairs, the lower ones by short stalks, but the upper ones are stalkless (sessile). The flowers are clustered, the calyces closely crowded, five-toothed. The corolla-tube may be from one to two inches long, the free end $(\lim b)$ divided into five lobes, which split irregularly into two opposite lips. It is rich in honey, the corolla being often half filled with it, and consequently it is a great favourite with bees and moths, who are 
$-31-$

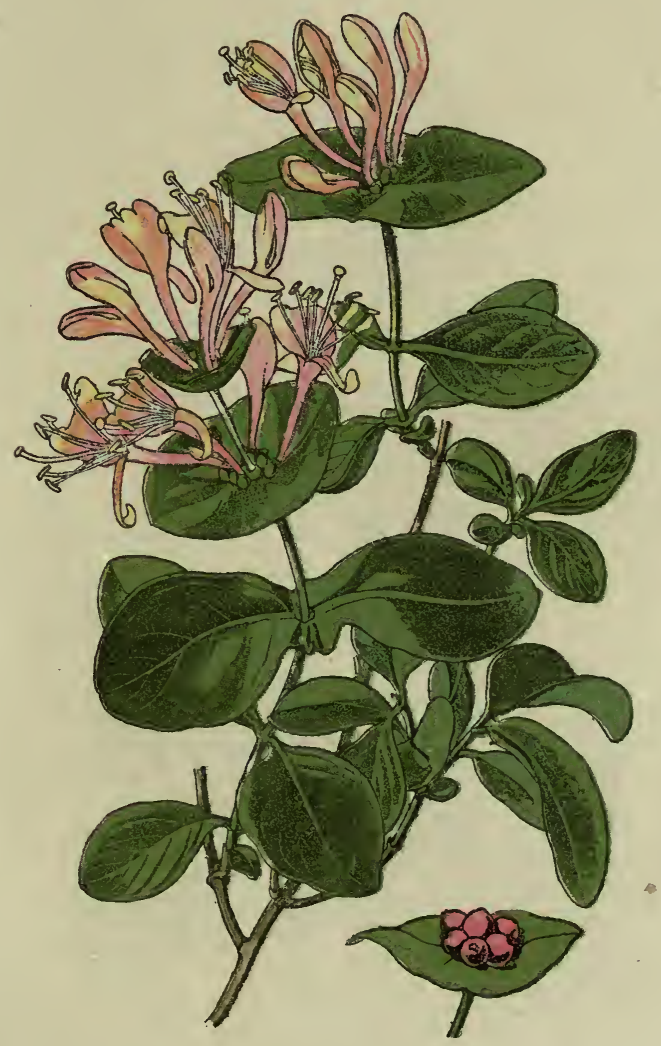

Perfoliate Honeysuckle.

Lonicera caprifolium.

- Caprifoliacez. - 
$-32-$

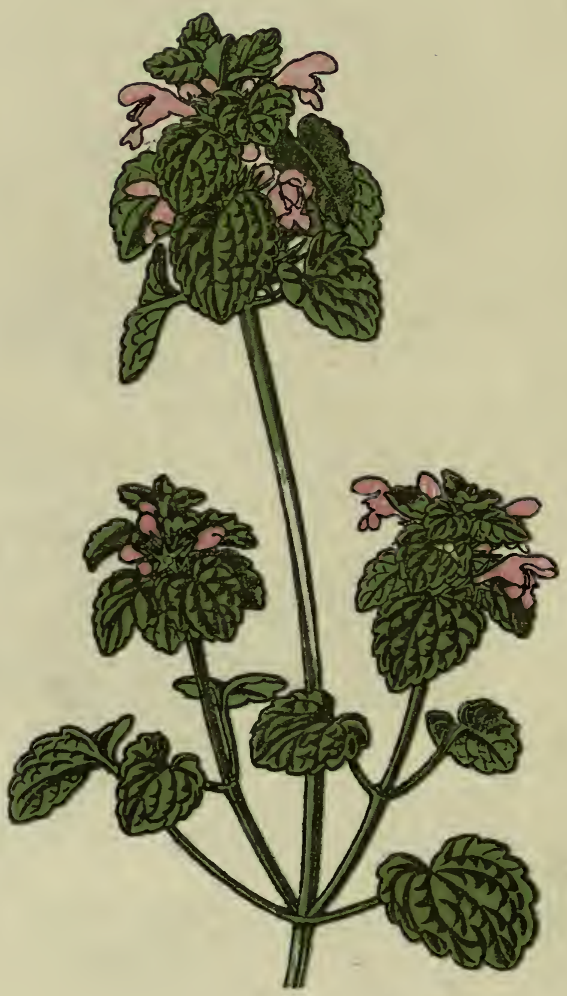

Purple Dead-nettle.

Lamium purpureum.

- Labiate. - 
bound to bring and fetch pollen from the outstanding anthers of one plant and deposit it upon the equally obtrusive stigma of another. The flowers are succeeded by a cluster of round crimson berries. Widely distributed in hedges, copses, and on heaths.

Perfoliate Honeysuckle (L. caprifolium) is similar to the last, but the upper pairs of leaves are joined together by their broad bases. The corolla-tubes are longer than in the common species, and it therefore becomes impossible for even the longest-tongued bees to carry off much of the honey. Moths with their long trunks can; and consequently they swarm upon it at night, and carry the pollen from plant to plant. This species may be found in copses in Oxfordshire and Cambridgeshire, but is believed to be only naturalized-not a true native. Flowers May and June. The name Lonicera was bestowed by Linnæus in honour of a German botanist named Adan Lonicer.

\section{Dead Nettles (Lamium).}

Our forefathers, when giving English names to plants, found it by no means easy work, and the greater number of our native species they left unnamed altogether. Many of the names they did invent were made to serve many times by the simple expedient of prefixing adjectives Thus. having decided on Nettle as the distinctive name of certain stinging herbs (Urtica), they made it available for the entirely unrelated genus Lamium by calling the species Dead (or stingless) nettles. In a similar fashion they made Hemp-nettle, and Hedge-nettle.

Apart from the resemblance in form of the leaves in certain species, there is little likeness between Lamium and Urtica, the large and graceful flowers of the former contrasting strongly with the inconspicuous green blossoms of the stinging 
nettles (see page 103). In the absence of flowers the difference may be quickly seen by cutting the stems across, when Urtica will exhibit a round solid section, whilst Lamium is square and tubular. The flowers, like those of Bugle (page 2I) and Meadow-Sage (p. 23) are labiate, and are produced in whorls. The calyx is tubular, with five teeth. The corolla tubular, with dilated throat, whence the name from Laimos (Gr.), throat. The British species are five :-

I. Red Dead Nettle (Lamium purpureum). Leaves heart-shaped, with rounded teeth, stalked. Bases of flower-bracts not overlapping. Corolla purplish-red. Whole plant often purple. Hedge-banks and waste places. April to October.

II. Intermediate Dead Nettle (L. intermedium). Intermediate between the first and the next species, but more robust. Bracts overlapping. Teeth much longer than calyx-tube, spreading. Cultivated ground, not in S. of England. June to September.

III. Henbit Deau Nettle (L. amplexicaule). Calyx more hairy than in I. and II. ; teeth equal to tube in length, converging when in fruit. Corolla slender, deep rose-colour, often deformed. Bracts broad, overlapping. Waste places. April to August. Above three species are annuals, the remainder perennials.

IV. White Dead Nettle ( $L$. album). Corolla large, creamy white, upper lip vaulted. Calyx teeth long. Waste places. March to December.

V. Yellow Archangel (L. galeobdolon). Corolla yellow, the lower lip orange, spotted with brown. Hedges and woods. May and June.

\section{Ground Ixy (Nepeta glechoma), and Iyy-leaved Toad-flax (Linaria cymbalaria).}

Trailing among the grass of the copse and hedgebank the Ground Ivy is one of the earliest of flowers to appear in spring. It has not the remotest relationship to the real ivy (Hedera helix), but, like the Dead Nettle, is a labiate plant. The slender square stem creeps along, and wherever it puts forth a pair of leaves it sends down a tuft of fibrous roots also. The leaves are roundish, kidney-shaped, deeply round-toothed on the margin. The flowers are borne in the axils of leaf-like bracts. The corolla-tube is long, slender at base, afterwards dilating. Some of the purple-blue flowers are large and perfect, others small and devoid of stamens. March to June. There is a closely allied, but rare, species called the Catmint ( $N$. cataria) 
$-33-$

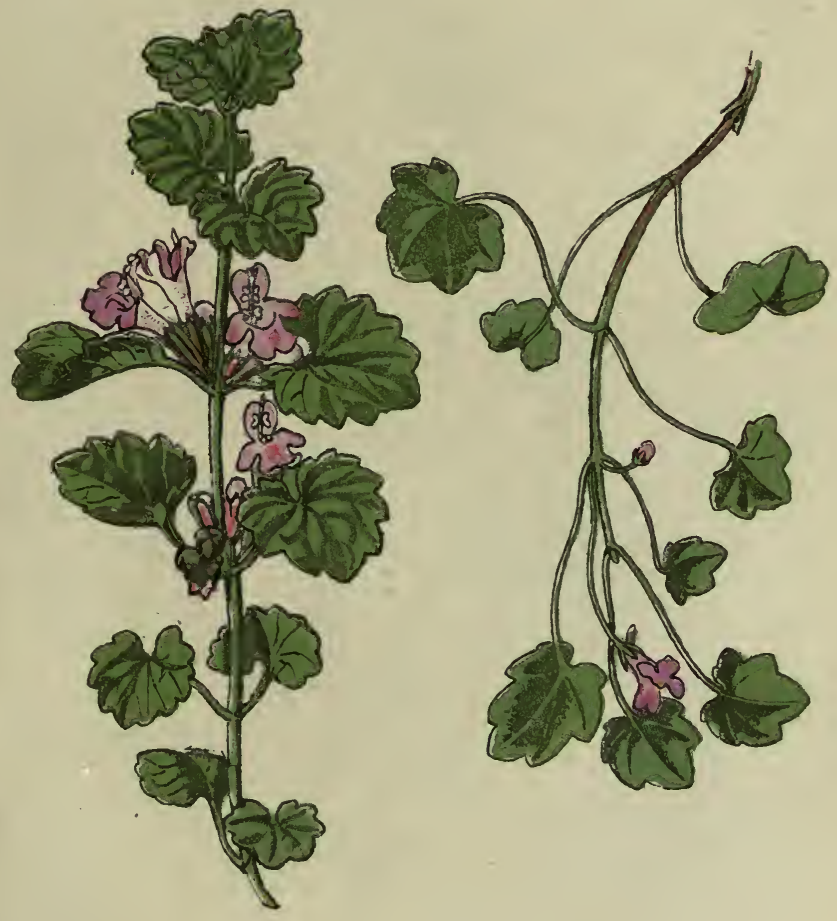

Ground Ivy.

Nepeta glechoma.

- LabiateA. -
Ivy-leaved Toadflax.

Linaria cymbalaria.

- ScRophUlarinex. - 

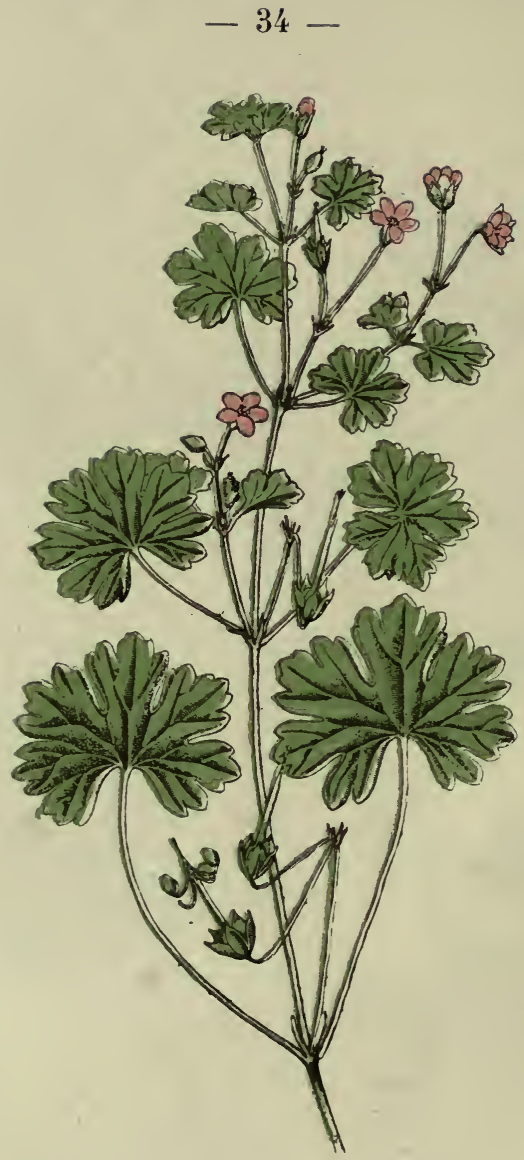

Round-leaved Grane's-bill.

Geranium rotundifolium.

- Geraniaces. - 
which flowers from July to September. This has an erect stem, with leaves approaching more to heart-shape, the teeth sharper; both stem and leaves downy and whitish. Flowers white, marked with rose-colour. The name Nepeta is the classical Latin one, and is said to have been given because the plant was common round the town of Nepet in Tuscany.

The Ivy-leaved Toad-flax (Linaria cymbalaria) will be found forming a beautiful tapestry on ruins and old walls. It is a Continental species, and those found naturalized here are believed to be the descendants of greenhouse escapes. The stems are very long and slender; the leaves lobed like certain forms of Ivy, often purple beneath, dark green above. The calyx is five-parted, and the corolla is like that of the familiar Snapdragon of our gardens. The two lips are so formed that they close the mouth of the corolla, which is hence said to be personate or masked ; the tube is spurred, in which it differs from Snapdragon. When the seed-capsule is nearly ripe it turns about on its stalk and seeks a cranny in the wall, where it can disperse its seeds. Flowers July to September. The name Linaria is derived from the Latin Linum, from the resemblance of the leaves of the common Toad-flax (see page 105) to those of the Flax (see page 96).

\section{Round-leaved Crane's-bill (Geranium rotundifolium).}

This neat member of a charming family is by no means a common plant ; in fact, northward of South Wales and Norfolk it is unknown. Southward it may be found in hedges and waste places, flowering in June and July. The stems are slight, and greatly swollen at the joints. The leaf-stalks are long, and the leaves, though their general outline is kidney-shaped, are deeply cut into about seven lobes, which are in turn lobed or toothed. Owing to the close general resemblance of this species to its immediate congeners some rather minute differences 
should be noted. The sepals end each in a hard point-in botanists' language they are mucronate-the margin of the narrow petals is entire, that is, not notched, and the narrow lower portion (claw) is not fringed with hairs. The carpels, or divisions of the seed-vessel, are keeled but not wrinkled, and the seeds are pitted. Its nearest allies are :-

I. The Dove's-foot Crane's-bill (G. molle), with similar leaves to the last, but with notched petals, the claw bearded. Flowers more rosy than rotundifolium.

II. Small-flowered Crane's-bill (G. pusillum). Leaves more deeply lohed, sepals as long as the notched petals, claw slightly hairy. Flowers, pale rose.

III. Long-stalked Crane's-bill (G. columbinum). Lobes of leaves distant from each other, the segments into which they are again cut being very narrow; sepals large, acuminate and awned, as long as the entire rose-purple petals; claws less hairy than in last. All the leaf and flower-stalks long.

IV. Cut-leaved Crane's-bill (G. dissectum). Similar to G. columbinum, but all stalks much shorter. Bright red petals, notched.

V. Herb-Robert (G. robertianum). Plant more or less red. Leaves divided into five leaflets, these again divided. Calyx angular, the sepals long-awned and hairy. Petals narrow and entire; purple streaked with red; claw smooth.

V1. Shining Crane's-bill (G. lucidum). Plant more or less crimson in summer. Leaves divided into five segments, each bluntly lobed at the top. The calyx is a wrinkled pyramid, each sepal awned. The rosy petals are much longer than the sepals; claw smooth. There are two lines of hairs on the upper branches.

All the above are annual or biennial plants. The name of the genus is from the Greek geranos, a crane, from a fancied resemblance in the fruit to a Crane's-bill.

The mechanism for the dispersal of seeds in the Crane's-bills is worthy of attention. When the petals fall off the carpels enlarge, and the outer layer of the style separates from the axis, splitting into five portions, each attached to a carpel at the bottom and to the style at top. The axis of the style further elongates, but the tails of the carpels do not, and there is, in consequence, great tension, which ends in the carpel being detached from its base. The "tail" curls up, the carpel is reversed, and the seed drops out.

\section{The Hemlock Stork's-bill (Erodium cicutarium).}

Closely related to the Crane's bills-and at one time included in the genus Geranium with them-are the Stork's-bills, of 
$-3 \check{-}$

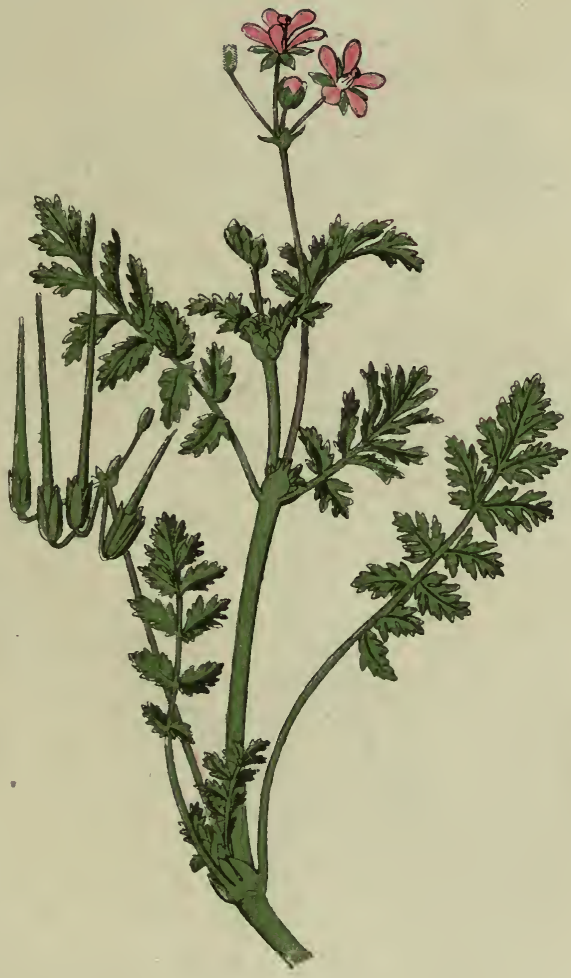

Stork's-bill.

Erodium cicutarium. 
$-36-$

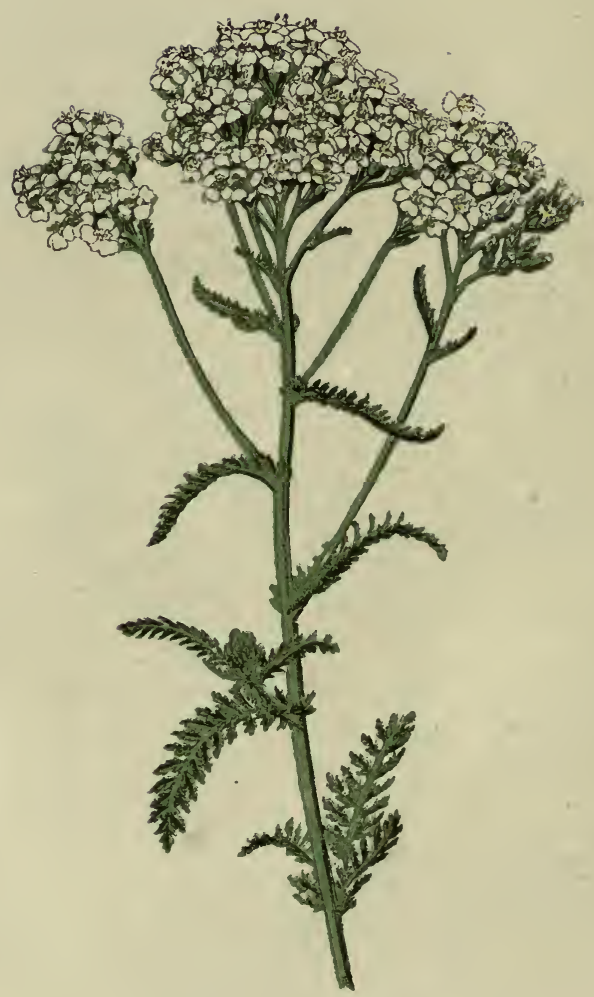

Milfoil. Yarrow.

Achillea millefolium.

- Composita. - 
which we have three British representatives. Only one of the three, however, is at all plentiful, and that is the one we have figured. It is a common species, but must be looked for on dry wastes and commons, especially near the coast. Quite apart from its umbels of pretty pink flowers it is a handsome plant. The leaves are cut up into a large number of leaflets, arranged in slightly irregular pairs on either side of the rib, and these leaflets are cut up into many irregular lobes. It is the arrangement so common in ferns : the leaf is pinnate, because it is furnished with pinnæ or wings, and as the pinnæ are themselves almost winged they are pinnatifid, or cut in a pinnate manner. The parts of the flower agree in number with Geranium, that is, sepals five, petals five, stamens ten (but five are aborted, and produce no anthers), stigmas five. The fruits agree pretty closely with those of the Crane's-bills, but in Erodium the tails of the carpels are lined on their inner face with fine silky hairs, and instead of curling simply they twist spirally, and cause the hairs to stand out at right angles. The seed remains attached to the tail, which becomes detached from the axis of the style and is blown to the ground. There the twisted tail is alternately lengthened and shortened by moisture and dryness of the atmosphere, and with assistance of the hairs this automatic movement gradually forces the pointed hairy seed into the ground. It flowers from June to September.

The Musky Stork's-bill (E. moschatum) is much larger than the last mentioned Easily identified by the strong smell of musk. Flowers June and July. Local.

The Sea Stork's-bill (E. maritimum). Leaves narrow, heart-shaped, lobed and toothed. Petals minute, pale pink, sometimes absent. Sandy and gravelly coasts : rare. May to September. Name from Greek, Erodios, a heron.

\section{Yarrow or Milfoil (Achillea millefolium).}

One of the commonest weeds in pastures, or on commons, roadside wastes, and often on lawns, is the Yarrow. Its leaves, as its second popular name indicates, are cut up into a large 
number of segments ; these are very slender and crowded, and are again cut up; so that the general aspect of the leaf is exceedingly light and feathery. This is especially the case with the leaves (radical) that spring directly from the creeping root; those given off by the flowering stem become more simple as they near the summit. Unlike as the flowers may at first sight appear to those of the Daisy and Dandelion, those of the Yarrow are also composites. The yellowish disc-florets are tubular, and contain both anthers and stigmas ; the white or pink ray-florets are pistillate only. It abounds on all commons, pastures and wastes, flowering from June till the end of the year. There is one other British species,

The Sneezewort ( $A$. ptarmica), which is almost as widely distributed. Its flower-heads are much fewer than in Yarrow, and its leaves are more simple in character, the edges being merely cut into teeth. The disc-florets are more green than yellow. It is about a month later than Yarrow in coming into flower, but thereafter the two species keep time together. The name Achillea was given to the genus in honour of Achilles, who is reputed to have used Yarrow for the purpose of staunching his wounds.

\section{Groundsel (Senecio vulgaris).}

We have selected this very vulgar plant as a familiar example of a genus that contains some very striking species. They all produce composite flowers, but in this common weed the rayflorets are usually wanting, and consequently the few cylindric flower-heads have a very singular appearance. The leaves are deeply cut, the lobes irregularly toothed. The flowers are succeeded by the well-known fluffy pappus attached to the seeds, which has enabled the plant to become one of the most widely distributed in all temperate and cold climates. It is to this hoary head of seed-bearers that the genus is indebted for its 
$-37-$

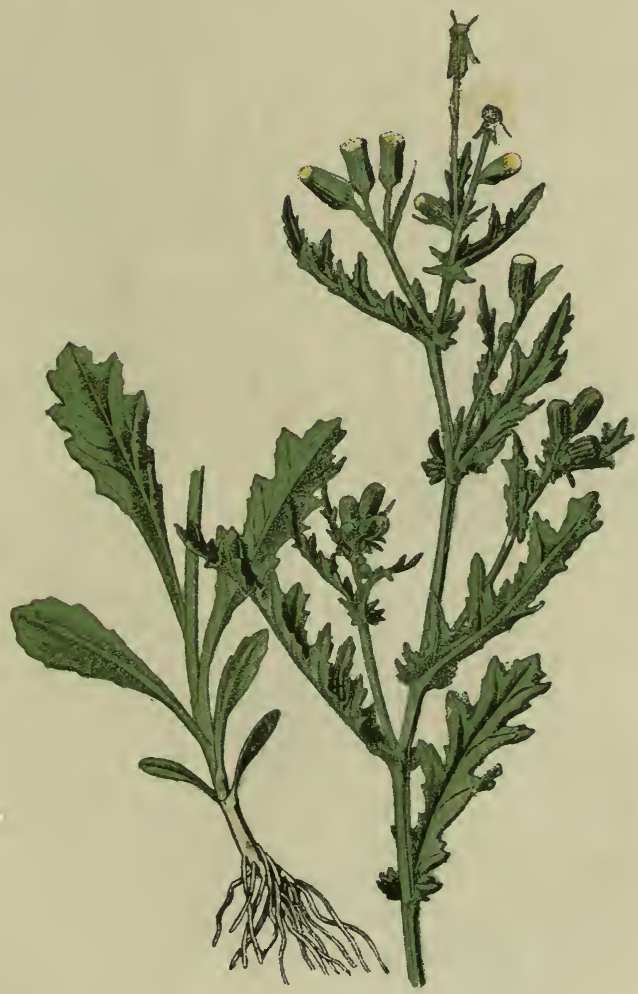

Groundsel.

Senecio vulgaris.

- Composita. - 
$-38-$

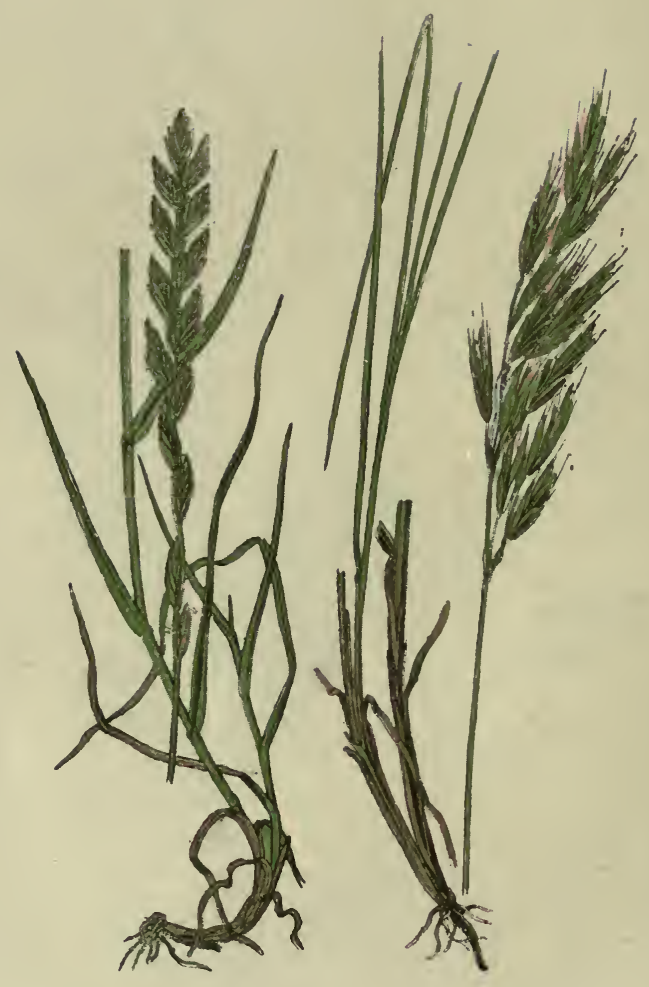

Rye-grass.

Lolium perenne.
Brome-grass.

Bromus erectus. 
name, which is derived from the Latin Senex-an old man. There are other eight British species, of which the most frequent are briefly noted below.

I. Mountain Groundsel (S. sylvaticus). Leaves similar to $S$. vulcaris, but divisions more accentuated. When the ray is present it is rolled back. The flowerheads are more numerous than in vulguris. Plant with unpleasant fotid smell. Dry upland banks and pastures. July to September.

II. Stinking Groundsel (S. viscosus). More objectionable-smelling than the last. Leaves broader, more divided, glandular, hairy and viscid. Plant much branched and spreading. Flowers larger : rays rolled back. Waste ground. Local. July and August.

III. Ragwort (S. jacobara). Stem thick and leafy, 2 to 4 feet high, somewhat cottony, with clusters of large golden yellow flower-heads with spreading rays Leaves finely lobed and toothed. Waysides, woods and pastures. June to October. Very plentiful.

IV. Hoary Ragwort ( $S$. erucifolius). Similar to the last, but the stem more loosely cottony; the segments of the leaves more regular and less divided; rootstock creeping. Hedges and roadsides. July and August.

V. Water Ragwort ( $S$. aquaticus). Like $S$. jacobaa, but of lesser growth Flowerheads larger, leaf-stalks longer. Wet places, riversides, ditches. July and August.

\section{Rye-grass (Loïum perenne), and \\ Upright Brome (Bromus erectus).}

The structure of grass-flowers has been already described, and the reader should refer back to page 19 . The inflorescence is a spike, the spikelets arranged in two rows, with their edges to the stem, which is channelled. There is only one outer glume, which is strongly ribbed, and shorter than the spikelet. The flowering glumes number from six to ten, or more.

This is one of the grasses that send forth leafy runners, which root and occupy surrounding ground. It is one of the most valuable to the farmer, on account of it early ripening, and its usefulness either for permanent pasture or for cropping. With good management as many as four crops may be obtained in one year. It grows in all waste places, and flowers in May. 
The Darnel ( $L$. temulentum) is its only native congener; an annual. It is similar to $L$. perenne, but produces no runners. Its presence among wheat is dreaded, as when ground up into flour it is believed to produce headache, vertigo, and other symptoms of poisoning. Darnel is the Tares of the New Testament, and is one of the very few grasses that are deleterious.

Upright Brome (Bromus erectus) is a perennial of strong growth, with stout creeping rootstock, sending up smooth and rigid stems 2 or 3 feet in height. The narrow leaves have their edges rolled inwards. The inflorescence is a lax panicle; the spikelets purplish in tint. The two empty glumes are unequal, and contain from five to eight flowering glumes, with awns, and hairy all over. There are seven other British species in the genus.

\section{Henbane (Hyoscyamus niger).}

At one time the Henbane was held in great esteem as a medicinal plant, and was then to be found very commonly on rubbish heaps, and the banks of ditches. Although it is still retained in the Pharmacopœia, its empirical use is not so great as formerly, neither does the plant appear to be so plentiful as of old. Its appearance and smell are somehow suggestive of its evil nature. It has a stout, branching stem, growing to a height of about two feet. The leaves are oblong, with irregular lobes, and the bases of the upper ones clasp the stem. The flowers spring from the axils of the leaves, and are almost stalkless. The calyx is pitcher-shaped, with a five-toothed mouth. The corolla is funnel-shaped, with five unequal lobes, and of a dingy yellow, streaked with purple-brown veins, though a form occurs with the corolla uniformly yellow. The five stamens are inserted at the base of the corolla-tube, and end in purple anthers, discharging their pollen by slits. The ovary is two-celled, supporting a simple style with a round head-the stigma. The whole plant is densely covered with sticky hairs.

On fertilization the ovary grows into a constricted capsule, with a distinct lid, which drops off to release the numerous seeds. It is the only British representative of the genus, which is said to get its name from two Greek words, Us, a hog, and Kuamos, a bean, but such etymology cannot be considered at all satisfactory. It flowers from June to August. 


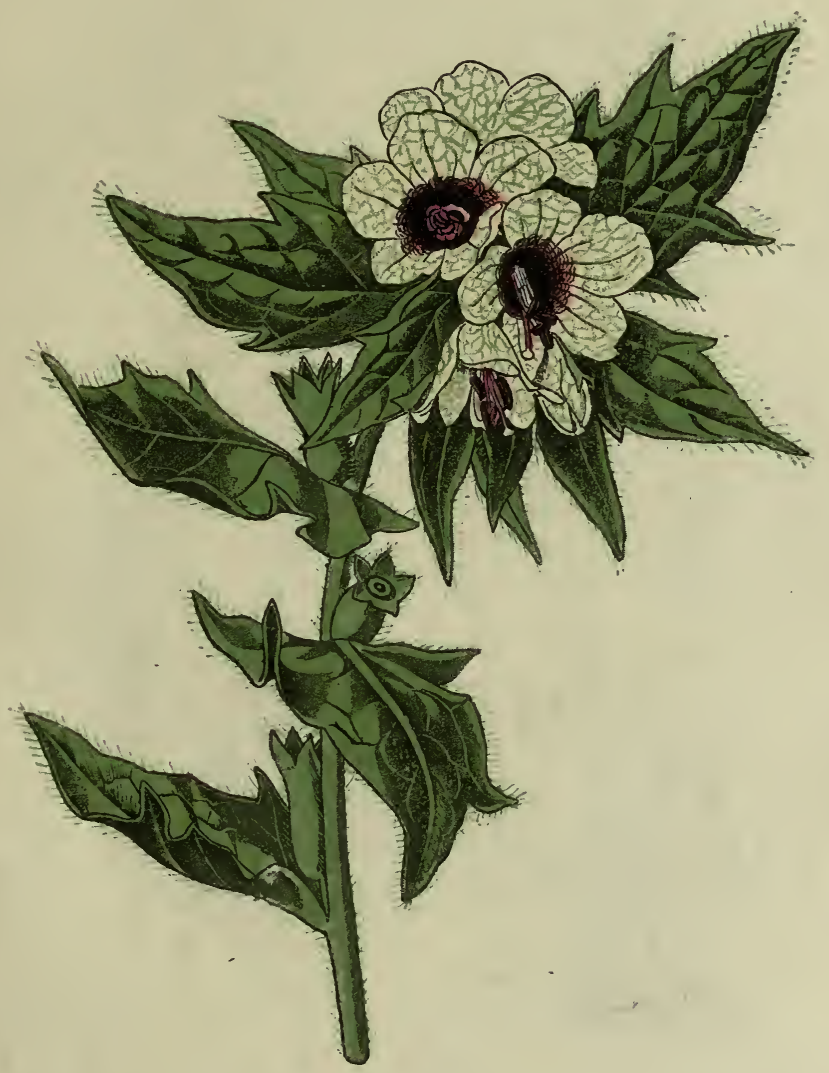

Henbane.

Hyoscyamus niger.

- Solanacez. - 


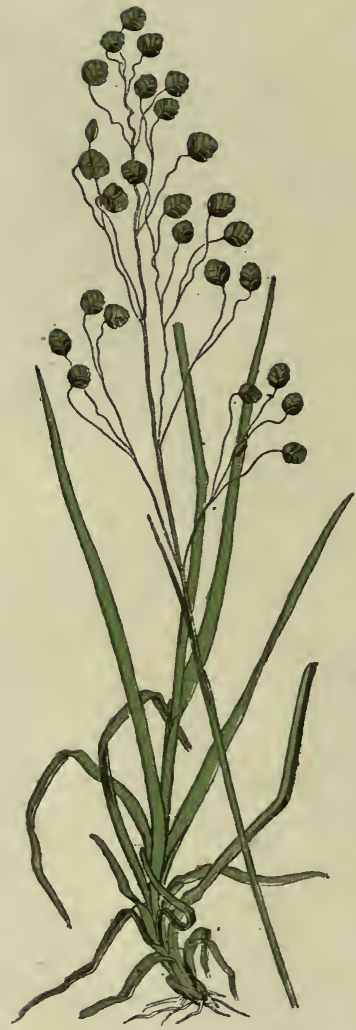

Quake-grass.

Briza media.

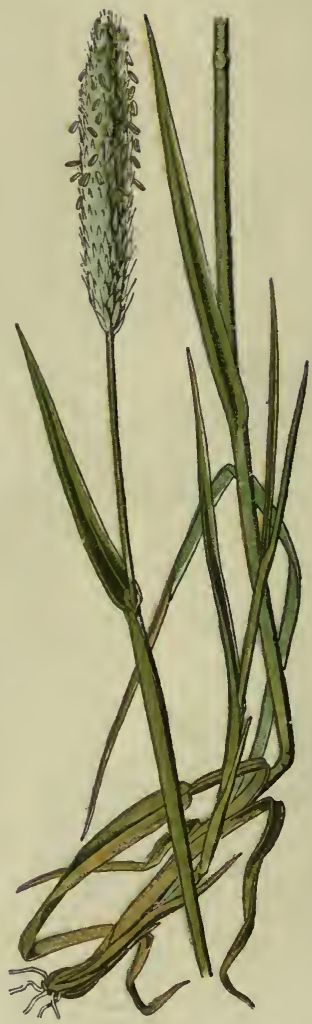

Foxtail-grass.

Alopecurus pratensis. 


\section{Quake or Totter-grass (Briza media), and Meadow Foxtail (Alopecurus pratensis).}

The Totter-grass differs so strongly in appearance from other grasses that minute description is unnecessary except as an aid in making out the structure. Every child that plays in the meadow singles this out as the most desirable acquisition among grasses, because of its constant tremblings. The inflorescence is a very loose pyramidal panicle, due to the extremely long and hair-like stalks upon which the shining purple spikelets are swung. The empty glumes are two; flowering glumes six to eight. The stem creeps below the surface, and the leaves are flat. The plant is perennial; but there is another species, the Small Quake-grass ( $B$. minor), that is annual. This is not so common a plant, and is found chiefly between Cornwall and Hampshire. It is much smaller than B. media, and has tufted stems; it flowers in July, media a month earlier. The name Briza is Greek, and was anciently applied to some kind of corn.

The Meadow Foxtail (Alopecurus pratensis) bears a general resemblance to Timothy (page 25), to which it is not distantly allied; but from which it differs in having no pale or scales. Its cylindrical panicle is yellowish-green, with silvery hairs, the branches bearing three to six spikelets. It is a perennial plant, and produces runners. It forms a valuable portion of all good pastures, the herbage being exceedingly nutritive. It flowers in May and June. The name is Greek, signifying Foxtail. There are three other native species in the genus :-

I. Slender Foxtail (A. agrestis). Annual. Panicle slender, often purplish, branches hairy, with two spikelets. A wayside weed. May to October.

II. Alpine Foxtail (A. alpinus). Perennial. Panicle ovate, short, $\frac{3}{4}$ inch, branches with four to six spikelets. Authers yellow. Rare, near alpine streams, from 2, 100 to 3,600 feet. Scrtland. July and August.

III. Floating Foxtail (A. geniculatus). Perennial. Stems, procumbent and rooting. Panicle dense, slender. Branches with one spikelet. Anthers purplish. Pools and wet places. May to August. 


\section{Dog-rose (Rosa canina).}

Probably most non-botanical ramblers feel able to distinguish at once between the Dog-rose and the Field-rose, and a few may be learned enough to separate either or both from the Burnet-rose and the Sweet-briar-and they may do it. But the scientific botanist has difficulties, and he is not quite sure where one species leaves off and another begins. Many workers have so split up our six or seven British roses into a vast multitude of species, sub-species, and varieties that it is difficult to follow them. In this work we shall not attempt it. The Dog-rose is the largest of the British roses. It forms a bush of considerable size, with long arching branches, covered with broad hooks. The leaves are broken up into five leaflets, each of which is sharply toothed. The sepals are five in number, pinnate, and turned back towards the stem when the flower is open. The petals are five, pink and notched. Stamens many. Styles free, hairy. The ovary is sunk in the calyx, which changes to the pitcher-shaped scarlet fruits-the "hips" of the schoolboy-in which are the hairy achenes. Flowers mostly solitary. Generally common in hedges and copses, flowering from June to August.

I. The Field-rose ( $R$. arvensis) is very similar to $R$. canina, but the flowers are generally in clusters, the petals white. Sepals falling off. In similar places. June and July. Easily distinguished by its trailing habit.

II. The Burnet- or Scotch-rose (G. spinosissima) is a much-branched shrub, with the leaves divided into seven or nine leaflets. Stem crowded with nearly straight prickles, showing every stage in the transition from thorns to stiff bristles and glandular hairs. Petals white or pink. Fruit nearly globular. Heaths and open places chiefly, on sand and chalk, especially near the sea. May and June.

III. Sweet Briar ( $R$. rubiginosa). A small bush with erect or arching branclies, set with hooked prickles mixed with glandular hairs and bristles. Leaflets densely glandular and aromatic. Flowers sinall, pink. Fruit globose. Bushy places, chiefly in South of England. June and July. 
$-41-$

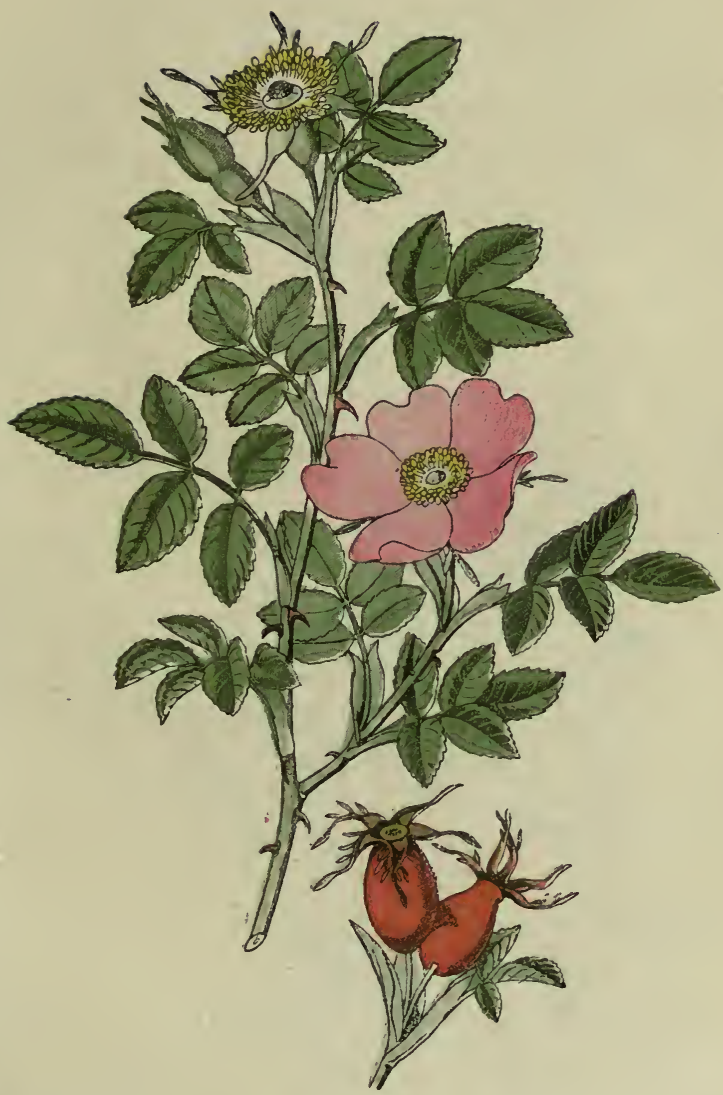

Dog-rose.

Rosa canina.

- ROSAGEe. - 


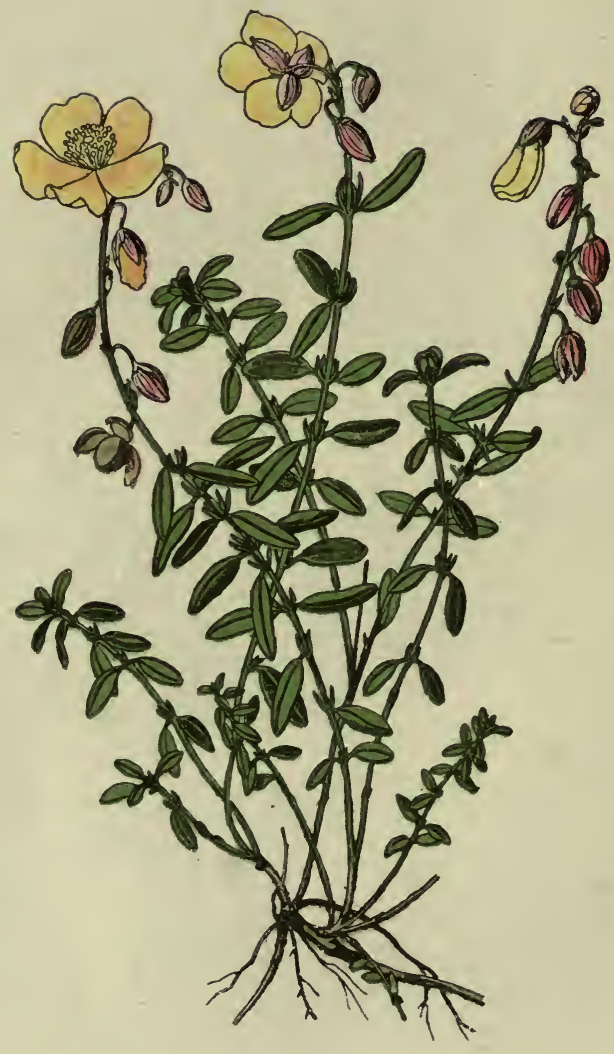

Rock-rose.

Helianthemum vulgare.

- Cistinex. - 


\section{Rock-rose (Helianthemum vulgare).}

On our chalk-downs, and on banks in gravelly soils, from June to September the pale yellow flowers of the Rock-rose are abundant. In spite of its plentifulness, however, it is not among those flowers that are generally known, except to the botanist. The rest of the world probably includes it among the buttercups, with which it has no relationship. The plant is shrubby, with a creeping rootstock; its branches trail on the ground among grass and low herbage. It is therefore by no means a conspicuous plant, though it occurs in considerable masses, and is perennial. The leaves are small, oblong, with an even margin; the upper surface hairy, the lower downy. They are arranged in pairs on the stem, and provided with stipules.

The flower-bud is protected by only three sepals, but there are two others reduced to the size and shape of stipules; and so their number really corresponds with the five somewhat flabby petals, which have the softness of the poppy rather than the stiffness of the buttercup. The stamens that surround the pistil are a multitude; they are also irritable, and on being touched fall back from the pistil. The plant is common throughout the country, except in Cornwall and West Scotland, in which districts it is rare. The name is Greek, and signifies sunflower.

There are three other British species:-

I. White Rock-rose ( $H$. polifolium). Similar, but more shrubby; margins of leaves curled back. Flowers white. Very rare. Stony places in Somerset and South Devon. May to July.

II. Spotted Annual Rock-rose (H. guttatum). An Annual, of erect habit; the lower leaves opposite, without stipules, the upper alternate, with stipules. Petals wedge-shaped, yellow, with a red spot at the base of each. Stony places, Anglesea and Holyhead; very rare. More freely near Cork and in the Channt Islands. June to August.

III. Dwarf Rock-rose (H. canum). More woody than the others; stems trailing. The whole plant hoary, and much branched. Leaves opposite, without stipules. Flowers yellow, not numerous. May to July, from Glamorgan to Westmoreland. 


\section{Bird's-foot Trefoil (Lotus corniculatus).}

From June to October our commons, pastures, downs and railway banks are bright with the flowers of Bird's-foot Trefoil, or as it is termed in some districts, Lady's Slipper, a name which properly belongs to the rare orchis Cypripedium.

The plant belongs to the same Natural Order (Leguminosa) as the Broom (see page 7 ante), and its flowers are of similar construction, though much smaller. There is a short, woody, perennial rootstock, from which originate several trailing branches, which are themselves much branched. The leaves are not trefoils, as the name would lead us to suppose, for the apparent stipules at the base of the leaf-stalk are in this genus leaflets. The flowers, which are in spreading heads of from three to ten flowers, are of a pretty yellow, tinted with red. They are succeeded by little cylindrical pods about an inch in length, which, when three or four are in a cluster, present the appearance of a bird's claws. The plant is a valued ingredient in the formation of pastures and meadows. The name was given to the genus because this was believed to be one of the plants to which the ancient Greeks applied the name Lotus.

There are three other species natives of Britain :-

I. Greater Bird's-foot Trefoil (L. uliginosus). More or less erect in habii. The calyx-teeth spreading in bud (in L.corniculatus they are erect in bud). Moist meadows and swampy places. July and August.

II. Hairy Bird's-foot Trefoil (L. hispidus). Annual, trailing stems, long and slender, covered with lax hairs. Pods twice the length of calyx. Banks near the sea from Hants to Cornwall. July and August. Rare.

III. Slender Bird's-foot Trefoil (L. angustissimus). Similar to $L$. hispidus, but stems shorter and more slender. Pod four times the length of calyx. Similar situations as last, but extending as far eastward as Kent. Very rare.

\section{Common Yetch (Vicia sativa). Plate 44.}

The Vetches are Leguminous plants, and the structure of the flowers is therefore very similar to those just described. The Vetches are chiefly climbing plants, and have pinnate 

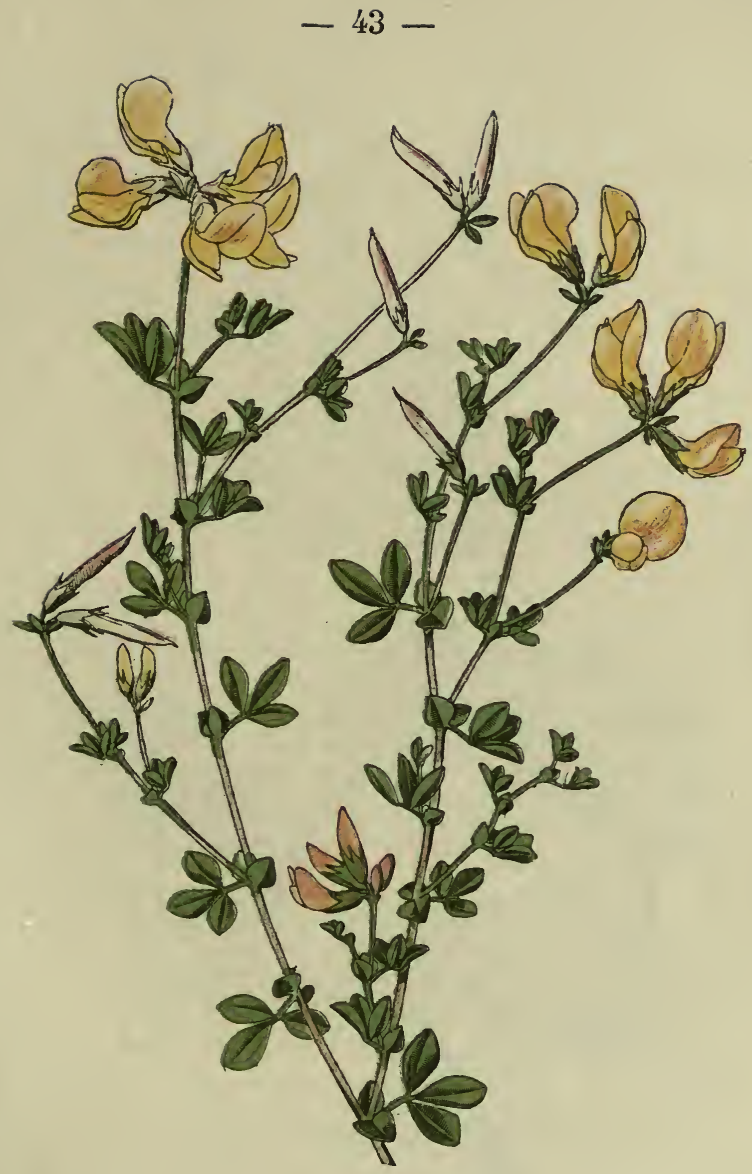

Bird's foot Trefoil. Lotus corniculatus. 


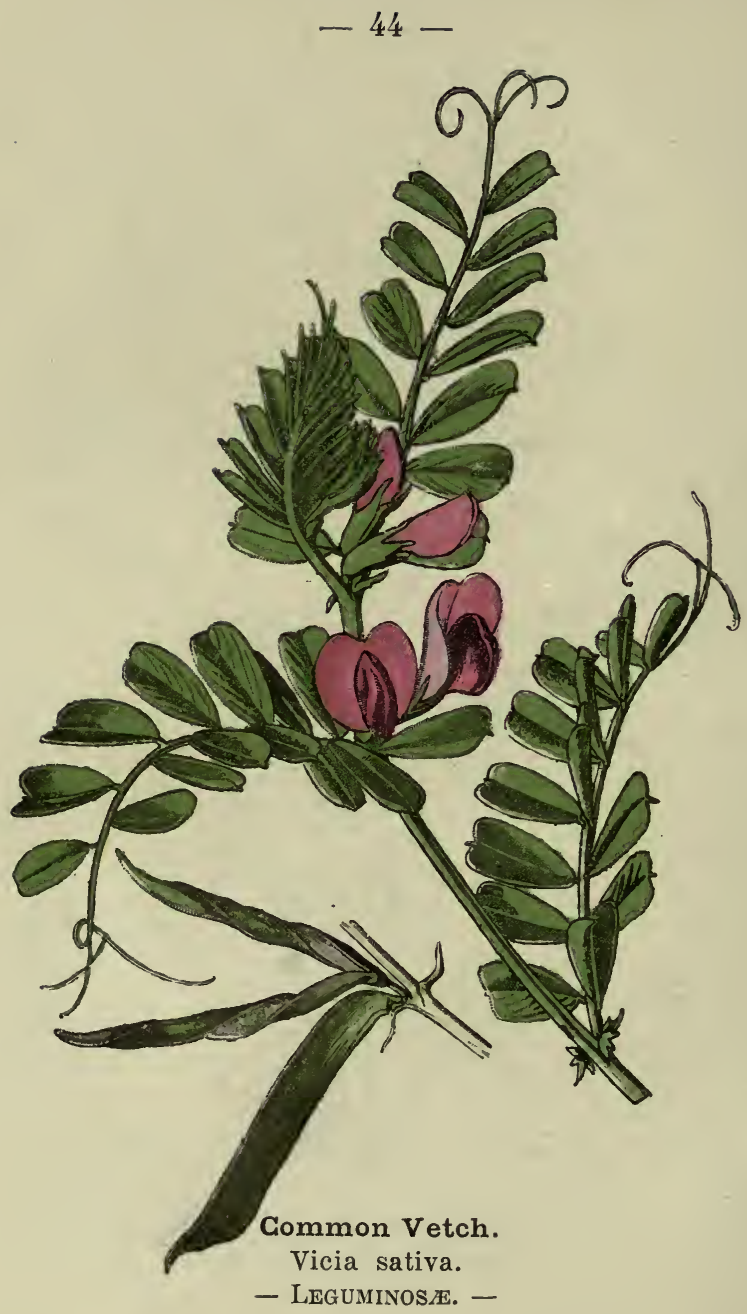


leaves. The leaflets are numerous, and the leaf-stalk is continued for some distance beyond the leafy portion, where it becomes a clasping tendril, often divided into three or four branches. The Common Vetch is to be found in hedges and roadsides near cornfields, flowering from April to June. The flowers are pale purple in colour, and are produced singly or in pairs from the axils of the leaves. By some authorities this is not considered a true species, but merely a cultivated form of the Narrow-leaved Vetch ( $V$. angustifolia). The seed-pods are slightly hairy, and from two to three inches in length. The name Vicia is the term by which the plants were known to the ancients and appears to have the same origin as Vinca (see page 5).

There are no less than ten British species of Vicia, but as some of these are very rare, we shall refer only to some of the commoner kinds.

I. Slender Tare $(V$.tetrasperma $)$. Stem very slender, about 2 feet in height. Flowers singly or in pairs, pale blue. Pods with three or four seeds. Hedges and cornfields. May to August.

II. Common Tare ( $V$. hirsuta). Similar to foregoing species, but hairy. Flowers smaller, pods shorter, hairy, and containing two seeds only. In similar situations. These are both annuals.

III. Tufted Vetch ( $V$. cracca). With creeping rootstock and angled stem, climbing or spreading; somewhat silky. The bright blue flowers are borne in a dense one-sided raceme, to the number of twenty or thirty. The pod is beaked, about an inch in length, and contains a large number of seeds. Hedges and bushy places. June to August. Perennial.

IV. Bitter Vetch ( $V$. orobus). Leaves in seven to ten pairs of leaflets, without tendrils. Stem erect, branched, hairy. The flowers purplish-white, ten to twenty, in loose one-sided racemes. Pod pointed at each end, containing four or five seeds. Rocky and mountainous woods on the western side of Britain. May to September.

V. Wood Vetch ( $V$. sylvatica). Perennial creeping rootstock. Stems, 3 to 6 feet, scrambling and trailing over bushes and undergrowth. Tencirils branched. Leaves beautifully divided into six or eight pairs of leaflets. Flowers white, streaked and veined with purple, and borne loosely in a one-sided raceme, to the number of eight to eighteen. A beautiful species, found only locally in woods at high elevation.

VI. Bush Vetch ( $V$. sepium). Creeping perennial rootstock, giving off runners. Leaflets, six to eight pairs. Flowers, dull purple, four to six in a cluster, not on a long stalk as in the Wood Vetch, but from the axils of the leaves, as in the Common Vetch. May to September. In hedges and bushy places. 


\section{The Duckweeds (Lemna).}

The Duckweeds-Shakespeare's "Green mantle of the standing pool"-are plants that are well-known to everybody, and consequently very few persons know anything of them. This is a paradox ; but they are so common and so small that the average man or woman is content to know them in the aggregate, and cannot condescend to a more intimate acquaintance with individuals, or with the different species, yet like many other small things-" unconsidered trifles"-they are very interesting to the botanist; for these are among the smallest and simplest of the flowering plants. Taking up two or three plants from one pond and comparing them with some from another piece of water, we shall probably find a difference in them; but they are all possessed of a more or less flattened green body that floats on the water, and which we shall be inclined to call a leaf. It is not a leaf, however, but a plant that produces no leaves, though it has roots and flowers. To be more accurate we will call it a frond, from whose undersurface there goes down one or more simple unbranched roots, and in clefts of whose margin are simple flowers. The flower consists of an envelope or spathe (see page 15), within which is a bottle-shaped pistil, with one or two stamens beside it. Some authorities contend that the pistil and each of the stamens is really a distinct flower similar to those in Arum. These flowers are so minute that they are rarely seen, and so are thought to flower only occasionally. The plant is chiefly multiplied by the production of new fronds from its edges. The four species figured give the whole of the genus, so far as Britain is concerned; but three others are known in foreign waters. The differences in the natives may be thus briefly enumerated :-

I. Least Duckweed (Lemna minor). The most frequent species. Frond not more than a quarter of an inch long, egg-shaped, the top flat and bright green, 

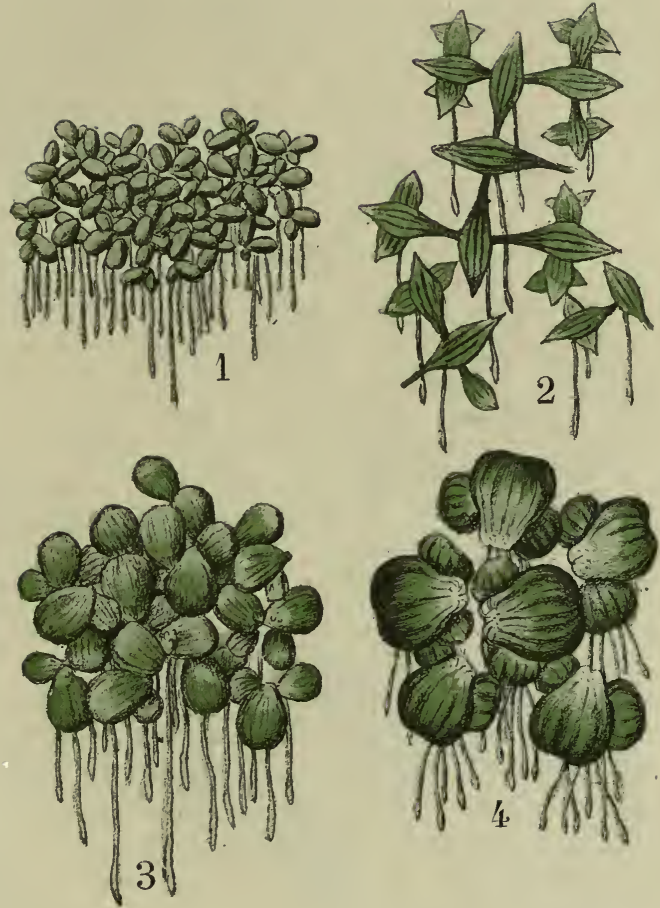

Duckneeds.

1. Lemna minor.

2. - tisulca.
3. Lemna gibba.

4. - polyrhiza. 


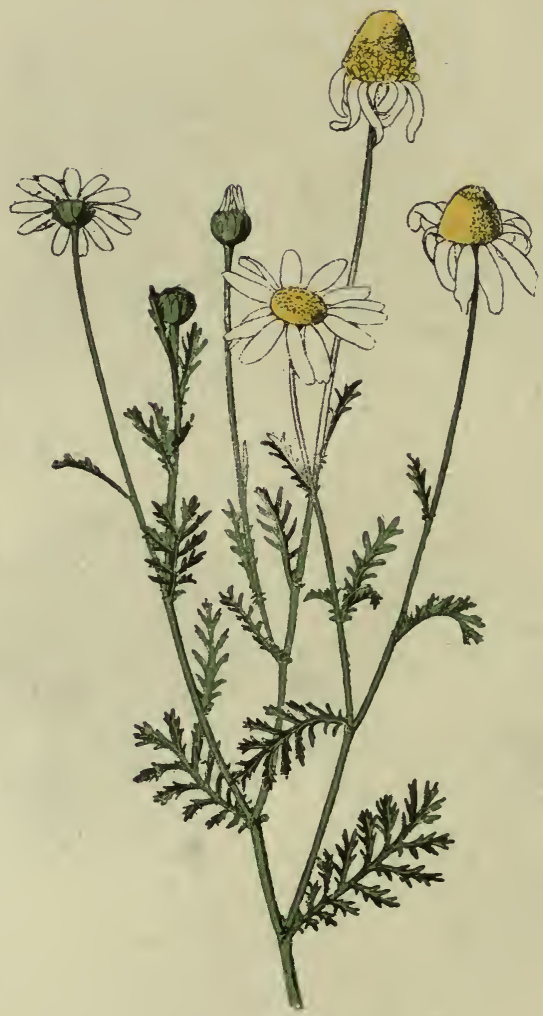

Gorn Ghamomile Anthemis arvensis. 
underside very pale green and slightly convex, with a single root. Spathe twolipped, one much larger than the other. Stamens two, one maturing before the other; style long. Flowering in July.

II. Ivy-leaved Duckweed ( $L$. trisulca). Frond thin and flat, nearly an inch long, tailed at one end, coarsely toothed at the other. New fronds emerge at right angles to the parent. Roots solitary. Stamens two; style short. June and July.

III. Thick-leaved Duckweed (L. gibba). Frond nearly round, narrowed at one end, large, almost flat, green opaque on top, greatly swollen beneath, whitish, clear, the cell-structure being very noticeable. Root solitary, stamens two. Flowers June to September.

IV. Great Duckweed (L. polyrhiza). At once distinguished from the others by its bunch of roots from each frond. Upper surface slightly convex, dark green with seven nerves. Underside purple, as also the upper margins. Stamens two. Flower has been rarely, if ever, seen in this country.

Late in Autumn the fronds sink to the bottom of the ponds and ditches, and remain there hibernating till Spring, when they arise to the surface, and again vegetate. The name of the genus is the old Greek appellation of the plant Lemna, supposed to be derived from Lepis, a scale.

\section{Corn Chamomile (Anthemis arvensis).}

We have already described several species of Compositæ, and now return to that order to describe a type of flower very similar in general appearance to the Daisy (page $\mathrm{I}$ ). The Corn Chamomile is an annual plant; the lower portion of its stem is prostrate, sending up erect branches with alternate, prettily cut leaves, twice pinnate. The flower-heads are borne singly on long stalks, and the floral envelope (involucre) consists of a number of over-lapping scales (bracts), whose margins are dry and chaffy. The base (receptacle) upon which the florets are packed is convex and covered with little chaffy scales, which stand up between the florets. The disc-florets contain both anthers and pistil; the ray-florets are pistillate only. The whole plant is downy. It occurs in fields and waste places, flowering from May to August. Though somewhat widely distributed, it is a local plant. The name is an old Greek name for the Chamomile, from anthemon, a flower, probably owing to the profusion of its blossoms.

The other British species of the genus are two only :- 
I. The Stinking May Weed (A. cotula). Ray-florets usually without pistils. The plant is smooth or hairy, not downy, but the leaves are quite smooth, and covered with minute glands, which secrete a fotid-smelling and acrid juice, causing swelling of the hands in persons clearing fields of this weed. The flower-stalks are more slender than in arvensis, and the involucral bracts are narrower at their tips. Fields, wastes and roadsides; very common in South of England, rare in the North. Flowers June to September.

II. The Chamomile (A. nobilis.) Perennial. Branches spreading from the root, leafy and furrowed, hollow. Leaves woolly, aromatic. Flower-stalk long and slender; involucre downy and chaffy. The ray-florets are sometimes wanting. In great favour as a remedy for indigestion. Gravelly pastures and dry wastes in England and Ireland. Rare. It is not a native of Scotland. Flowers July to September.

\section{St. John's Wort (Hypericum perforatum).}

There are no less than eleven native species of St. John's Wort, all characterized by a neat habit, clean-cut leaves without stalks, yellow flowers in cymose clusters, and a multitude • of stamens, which are more or less joined in several bundles.

The species represented on our plate is one of the commonest, and occurs in copses and hedgebanks throughout the kingdom, as far north as Sutherland, flowering from July to September. It is very erect in habit, the stems two-edged, pale brown and smooth, two or three feet high. If the leaves are held up to the light it will be found that the veins (but not the reticulations) are pellucid, and that the leaf is thickly dotted with pellucid glands. The flowers are $\mathrm{I}$ to $\mathrm{I} \frac{1}{4}$ inch in diameter. The calyx, corolla, and sometimes leaves are more or less marked with black dots and lines. The sepals and petals are each five in number; the ovary large, pear-shaped, surmounted by three long styles, which are longer than the ovary. The stamens joined in three bundles by their bases only. Sepals glandular.

Among the other British species are :-

I. Square-stalked St. John's Wort (H. tetrapterim). Stem with four narrow wings, I to 2 feet, leaves broader than in perforatum, but the glands, veins and reticulations are pellucid. Styles shorter than the ovary. Flowers dense, $\frac{1}{2}$ to $\frac{s}{4}$ inch. across. Moist places, July and August. 


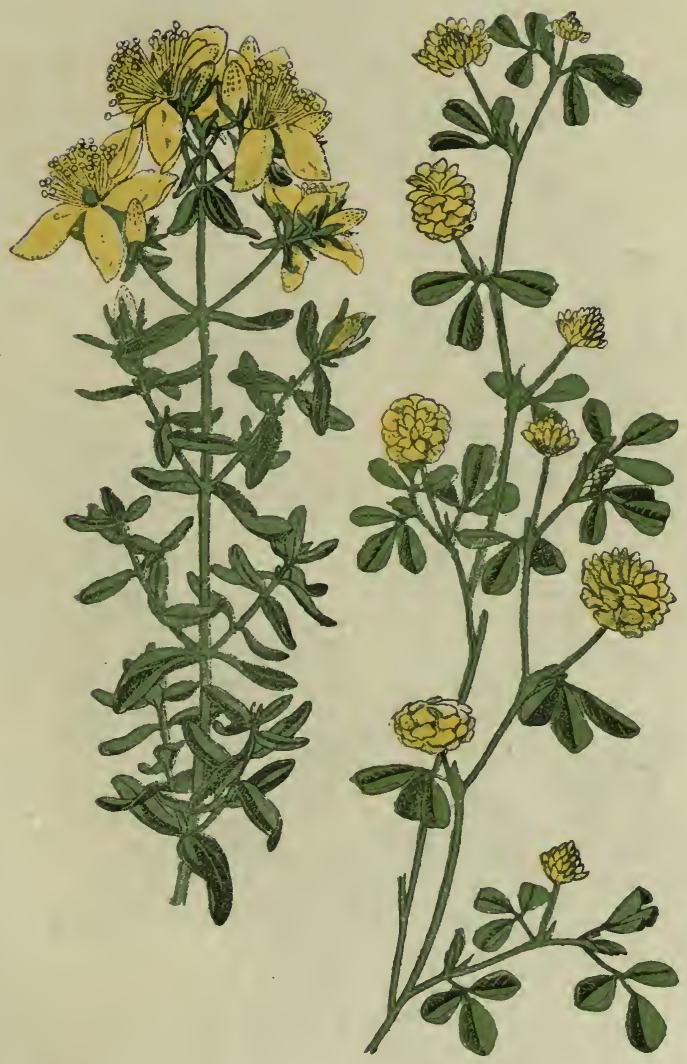

St John's Wort.

Hypericum perforatum. - Hypericinea. -
Hop Trefoil.

Trifolium procumbens.

- Leguminos.e. - 


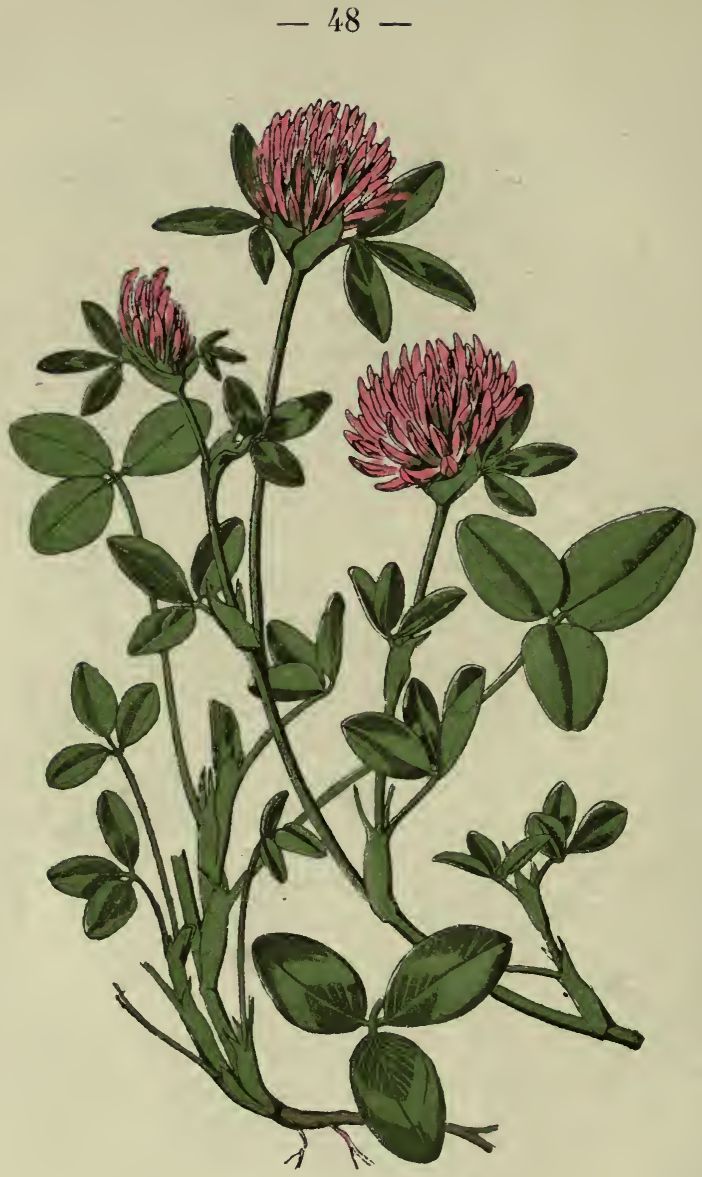

Red Clover.

Trifolium pratense.

- Leguminose. - 
II. Trailing St. John's Wort (H. humifusum). Stems slender, compressed, prostrate, not exceeding a foot. Leaves small, oblong; glands pellucid; the margins are often marked with black glands, and are sometimes rolled back. Flowers, $\frac{1}{b}$ inch across. Sepals unequal. Styles very short. Commons and wastes. July and August.

III. Small Upright St. John's Wort (H. pulchrum). Stems slender, round, smooth, erect. Leaves heart-shaped, with pellucid glands. Sepals small, oblong, with black glandular teeth. Petals yellow, tinged with red, and edged with black glands. Styles short ; anthers red. Flowers $\frac{8}{4}$ inch, loose panicles. Dry woods and heaths. June and July.

IV. Hairy St. John's Wort (H: hirsutum). Stem erect, round, downy. Leaves large, with short stalks. downy beneath, pellucid glands. Sepals very narrow, half length of petals, with black glandular teeth. Woods and thickets, especially on chalk. July and August.

V. Tutsan $(H$. androsamum). Stem shrubby, compressed, 2 feet high. Flowers few, $\frac{3}{4}$ inch across. Sepals unequal, glandular, except margin. Petals and stamens not permanent. Stamens in five bundles. Styles shorter than stamens. Hedges and thickets. July to September.

\section{Clovers (Trifolium).}

Everybody knows a Clover when he sees it ; it is therefore unnecessary to take up our space with a general description. Their great value as pasture plants has caused their typical forms of flower and leaf to be well known; but we have so many native species, to say nothing of the introduced kinds, that few besides botanists and agriculturists are acquainted with their specific characters.

All the Clovers or Trefoils are Leguminous plants, and the structure of the individual flower is very similar to that of Lotus and Vicia; but the flowers are much smaller, and are gathered into a conspicuous head. In certain species there are floral bracts, and in some these form an involucre. It is characteristic of most of the clovers that when the seed is set the petals do not fall off, but simply dry up and wrap round the pod. The name of the genus is Latin, and signifies threeleaved. The principal British species are :-

I. Subterranean Trefoil ( $T$. subterraneum), so called from its singular habit of 
bu:ying its pods in the earth when they are ripening. The plant has many creeping stems, covered with soft hairs. The heads of flowers are cream-coloured, and are produced in the axils. The individual flowers are long and slender; only a few in each head are fertile, and in this species the petals fall off early. The pod is a compressed orb. Dry, gravelly pastures. May and June.

II. Hare's-foot Trefoil ( $T$. arvense). Stems almost erect. Flower-heads numerous, dense, cylindric, softly hairy; flowers pinky-white, minute; teeth of the calyx longer than the corolla. Corn-fields and dry pastures. July to September.

III. Common Purple or Red Clover ( $T$. pratense). (See figure.) This is the clover so commonly grown in meadows as an important ingredient in the hay-crop. Its large oval leaflets are frequently marked with a whitish band that takes more or less of a quarter-moon shape. Its-flower-heads are round, afterwards becoming longer than broad, purplish red in colour. Calyx-teeth slender, bristly, not longer than corolla. Top of pod dropping off when ripe. This is the clover Darwin made famous by showing that the cultivated forms must die out but for the humble-bees, whose tongues alone are long enough to fertilize its long flowers. Meadows, pastures and roadsides. May to September.

IV. Zigzag or Meadow Clover ( $T$. medium). Leaflets more pointed than in pratense, and spotless. Stem branched in such a manner as to give it a peculiarly zigzag appearance. Heads larger, and of a deeper purple than pratense. Calyxteeth half the length of corolla. Pod splitting lengthwise. Pastures, flourishing in lighter soils than pratense. June to September.

V. Soft Knotted Trefoil ( $T$. striatum). Stem more or less reclining, downy or silky. Flower-heads both terminal and axillary, small, rosy-red, broader at the base. Calyx-tube swollen, ribbed, contracted at mouth, teeth not so long as corolla. Dry pastures. June and July.

VI. Rough Rigid Trefoil ( $T$. scabrum). Stems rigid, prostrate. Leaflets rigid, toothed, the veins thickened. Flower-heads hroadest in middle. Flowers small, the corolla white, calyx purple; calyx-teeth as long as corolla. Chalky and sandy pastures near sea. May to July.

VII. Dutch Clover ( $T$. repens). Stems smooth, creeping, but not rooting. Leaflets often with a dark spot at the base, below a whitish band. Heads of flowers globose, all produced from the axils, on long stalks. The flowers white or pinkish, attached by short stalks, which are recurved after flowering, so that the pods are all drooping. Meadows and pastures. May to October.

VIII. Strawberry-headed Clover ( $T$. fragiferum). Similar in habit to the last. Flower-head globose, of small purple-red flowers, much larger after flowering, when the calyces swell and take on a red colour, which increases size of head to an inch in diameter, and gives it a strawberry-like aspect. Meadows and pastures. July and August.

IX. Hop Trefoil ( $T$. procumbens.) (See Figure on p. 47.) This must not be confounded with the Hop Trefoil of the farmer (Medicago lupulina), in which the flowers are borne in spikes (see p. 73). The stems are downy, one growing erect, others all round it creeping. The flowers are pale yellow, crowded in the heads, the upper petal (standard) broad, and arched over the straight pod, turning bright brown, which gives the head the appearance of a hop strobile. The pods are 


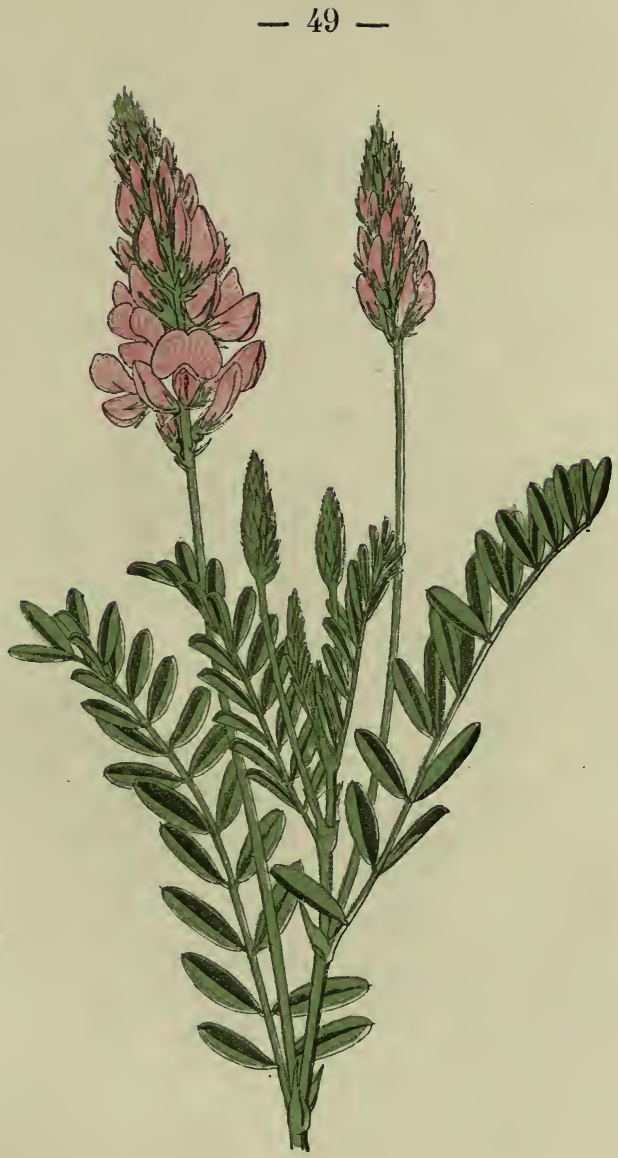

Sainfoin.

Onobrychis sativa.

- Leguminose. - 


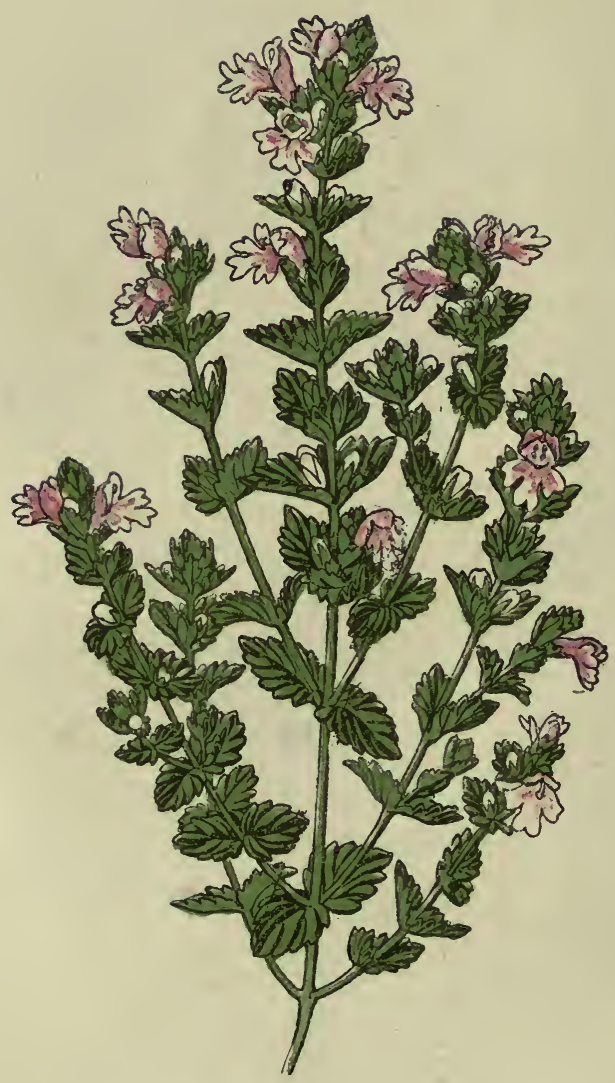

Eyebright.

Euphrasia officinalis.

- SCRophularinez. - 
alway's so covered in this species, whereas, in Medicago lupulina they are naked. Dry pastures and roadsides. June to August.

X. Small Yellow Trefoil (T. dubium). Stems slight, creeping, nearly smooth. Heads smaller, on long slender stalk. Flowers yellow, the standard narrow, keeled, turning dark brown after flowering and wrapped round the pod. Similar situations and date to last.

\section{Sain Foin (Onobrychis sativa). Plate 49.}

Still keeping to the Leguminous plants, we have here a handsome herb of aspect very diffierent from that of the Trefoils. It is much cultivated as a fodder plant in dry fields, but will also be found growing wild on chalk-hills and downs. It is, however, suspected of being an escape from cultivation that has taken to an independent life. The plant springs from a perennial woody rootstock, and its stout downy stems are more or less erect. The leaves are pinnate, the leaflets in about twelve pairs and a terminal one. The flowers are in spikes, the standard broad; bright clear pink, veined with a deeper rosy tint. The pod is semicircular, wrinkled, and contains but one seed. Flowers June to August. The name is derived from two Greek words, signifying the braying of an ass, because that animal is fabled to bray after it when he sees but cannot reach it.

\section{Eyebright (Euphrasia officinalis).}

From the close-cropped turf of our commons and in meadows the bright eyes of this plant peep out through the summer. In such situations it is a very lowly herb, only an inch or so in height, but in some places, as in the pastures of the Highlands, it grows erect to a height of nearly a foot, with many opposite branches. The leaves are ovate, opposite, without stalks, and of a dark-green hue. The flowers are borne near the extremities of the branches. Some of the flowers are much larger than others, and in the larger the 
stigmas ripen before the anthers; in the smaller the anthers mature before the stigmas. The tubular calyx is divided into four sharp lobes. The corolla is white, streaked with purple, except the central lobe of the lower lip, which is yellow. This is the only native species of the genus-which is comprised in the order Scrophularineæ-though there are several varietal forms. Flowers from May to September. The name is from the Greek, Euphraino, to delight or gladden, in allusion to the pleasing contrast of its bright flowers with the dark foliage, or from its supposed efficacy for complaints affecting the eyes-its removal of these giving gladness.

The plant is - at least partially - a parasite, and preys upon the roots of other plants, which it robs. Probably the lowly forms to which we have referred may be less parasitic than those of greater stature; for if the seeds are sown in pots by themselves they will germinate and grow, but will never get large robust plants.

\section{Great Reed Mace (Typha latifolia).}

Of late years it has become the general error to call this plant Bulrush, a name which belongs by right to Scirpus lacustris. Every autumn the hawkers in London and other cities offer the cylindrical spikes of Typha for sale as æsthetic decorations, and call them bulrushes; but they are not the originators of the blunder. It is the artists who have done this thing, especially one Delaroche, whose picture of "The Finding of Moses" is of world-wide popularity. In that painting he depicted the future leader of his people rocking in his ark amid a forest of Typha. What more was needed to associate the word bulrush of the Bible (itself a blunder of the learned translators) with this plant?

There are two British species, perennial plants with long, narrow, grass-like leaves, the bases of which sheath the stem. 
$-51-$

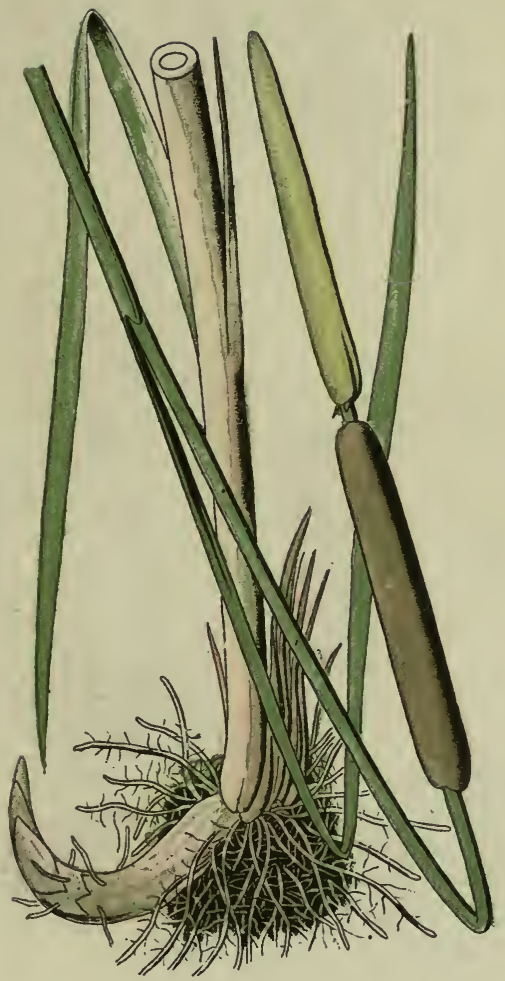

Reed mace.

Typha latifolia.

- TYPHACEE. - 
$-52-$

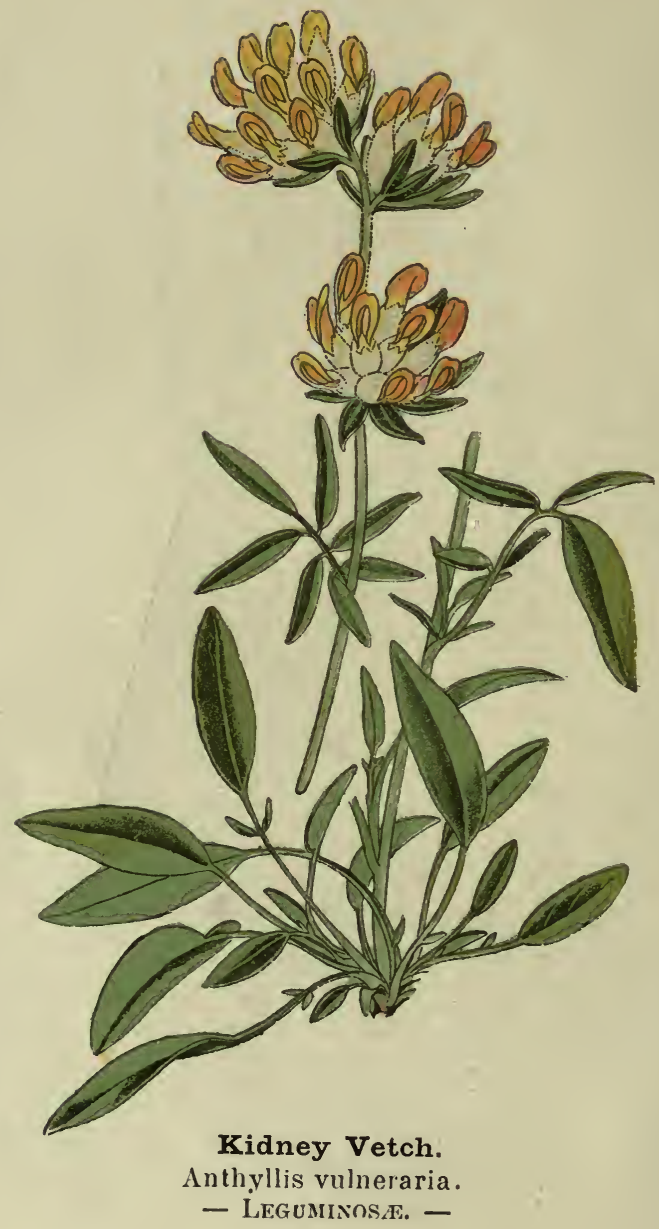


The stamens and pistils are produced in separate flowers, but upon the same plant. The flowers have no perianth other than a few slender hairs. The staminate flowers occupy the upper portion of the well-known spike or "mace," and consist simply of several stamens joined together, the anthers opening along their sides. The pistillate flowers consist of a stalked ovary with a slender style and a one-sided narrow stigma. The specific differences are as follows :-

I. Great Reed Mace ( $T$. latifolia). Leaves as much as an inch and a half broad, in two rows, bluish-green. Flowering stem naked, 6 or 7 feet high. Staminate and pistillate spikes continuous, or but slightly interrupted. Growing in lakes and on the banks of rivers. Flowering in July and August.

II. Lesser Reed Mace ( $T$. angustifolia). Whole plant smaller. Leaves half the width, dark green, grooved at lower end. Staminate and pistillate spikes separated by an interval. Stigmas broader. Ditches and pools. Less common than latifolia. Flowering July.

Name from Greek, Tiphos, a fen or marsh, from the habitat.

\section{Kidney Vetch (Anthyllis vulneraria).}

The Kidney-vetch or Lady's fingers was celebrated from early times as a plant that was efficacious in the cure of wounds, and hence its specific name vulneraria. There is no doubt that this reputation was well-founded, for its bluish leaves are covered with silky hairs and its calyces downy. It is a perennial herb that affects dry pastures and rocky banks. From a woody rootstock arise several stems and a large number of radical leaves ; these consist of a long terminal leaflet and two disproportionately small lateral leaflets. The leaves from the stems (caudal leaves) have a larger number of leaflets in pairs, as well as a terminal one. The flowers are borne in heads, with an involucre of leaflets, and the heads are chiefly in pairs. The calyx is membranous, and therefore permanent, the mouth oblique, with fine teeth. The petals are nearly equal in length, and typically yellow, but subject to considerable variation. After flowering the straw-coloured calyx becomes inflated, and the 
roundish smooth and veined pod with its solitary seed is hidden within. In some of the coast localities for this plant it will be found with flowers white, cream-coloured, crimson, and purple; this has been especially noted at the Lizard in Cornwall. It is ordinarily in flower from June to August. This is the only British species.

The name is the one in use among the ancient Greeks, and signifies bearded flower, which is obviously a reference to the woolly calyces.

\section{Ox-eye Daisy (Chrysanthemum leucanthemum).}

We have already given several examples of Composite flowers, and an examination of the Ox-eye Daisy would quickly convince the reader that he has another Composite under consideration. The popular eye noted long ago its similarity to a big daisy, and named it accordingly. In Scotland, too, where the daisy is known as a "gowan," the resemblance has been recorded by calling the Ox-eye a "horse gowan." If reference be made back to the Daisy (page I), it will be seen that the involucre consists of a single series of green scales, whilst in the Ox-eye this part of the flower consists of three or four series of scales with thin brown or purple edges, overlapping each other after the manner of the tiles on a roof. The white ray-florets are notched at the ends, unlike those of the Daisy. The Ox-eye, too, it will be noted, has a distinct stem, the leaves of which differ from those produced directly from the rootstock, being narrower, deeply toothed and stalkless. It is but too abundant in pastures and hay fields, which are effectively whitened by its flowers from May to August. The name is from two Greek words, Chrysos, golden, and anthemon, flowers, from the golden discs of the flower-heads.

There are two other British species :-

I. Corn Marigold (C. segetum). A troublesome annual weed in cornfields, but 
$-53-$

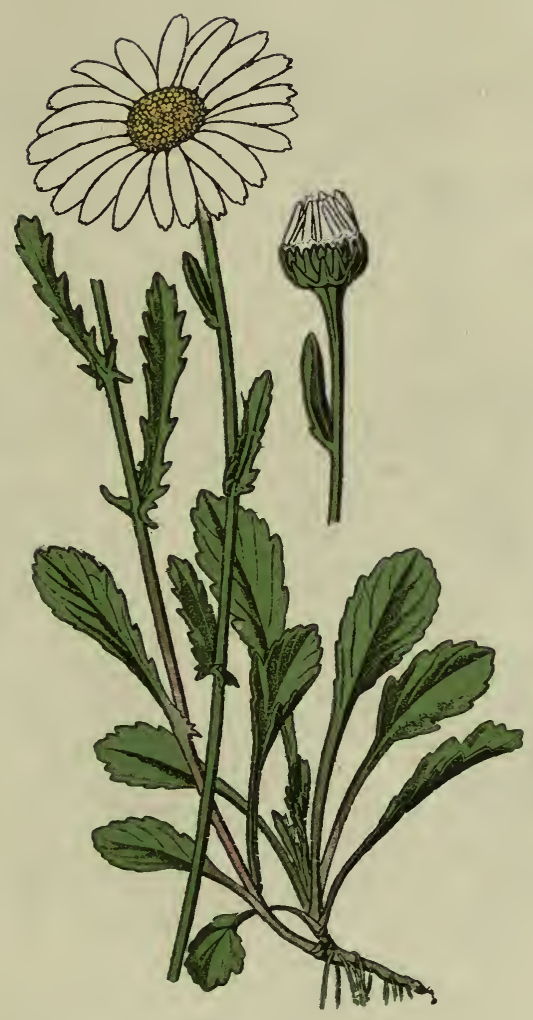

Ox-eye Daisy.

Chrysanthemum leucanthemum.

- Composite. - 
$-54-$
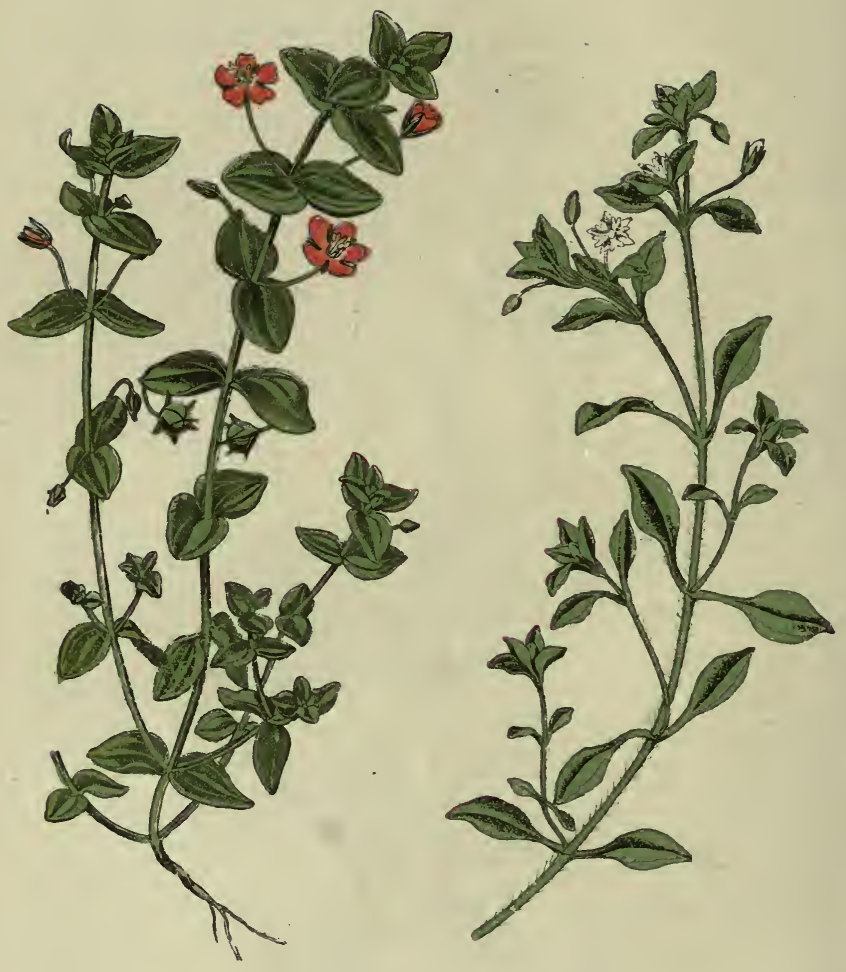

Pimpernel.

Anagallis arvensis.

- Primulaces. -

Chickweed.

Stellaria media.

- Cisryophylle.e. - 
as handsome as it is mischievous. Its ray-florets are of a deep yellow hue, their tips not notched but divided into two lobes by a central indentation. The involucral bracts are broad, with wide margins. Flowers June to September.

II. Fever Few (C. parthenium). I.ike the Ox-eye, this is a perennial plant with a much-branched erect stem, broad pinnate leaves, downy and aromatic. The flower-heads are small, and are clustered in many-headed flat-topped bouquets (corymbs). The white rays are short and broad. Whole plant bitter and tonic. Waste places and hedgebanks. July to September.

\section{Pimpernel (Anagallis arvensis).}

The Scarlet Pimpernel, or Poor Man's Weather-glass, is one of those wild flowers with which every country-dweller is acquainted, for it has long enjoyed a reputation as a cheap barometer, in consequence of its habit of closing the petals over the essential organs on the approach of rain. The genus Anagallis belongs to the order Primulaceæ, at whose characteristics we have already glanced (see page 2 ). It has a square stem, which lies along the ground and sends up many erect branches. The leaves are ovate, the margins entire, stalkless, usually borne in pairs, but occasionally in threes or fours. The flowers are produced singly, on very long and slender stalks, from the axils of the leaves. The sepals are narrow, sharp-pointed, almost as long as the corolla. When the flower has passed, their long stalks curve downwards with the globose seed-vessel. When these are ripe they open by a clean fissure all round, so that the upper half falls off and discloses the numerous seeds. There is a variety often found with blue flowers, which was formerly regarded as a distinct species, but experiments with the seeds have proved it to be a mere variety. One or other of these forms is common in all fields and wastes from May till November.

The Bog Pimpernel ( $A$. tenella) is a distinct and very beautiful species. It has a creeping and rooting stem, with small broadly-ovate leaves on short stalks. The flower-stalks are shorter and stouter than in arvensis, and the sepals much shorter than the graceful pale-rosy funnel-shaped corolla, which is very large in proportion to the leaves and stem. It may be found in boggy places growing amid sphagnummoss, and flowering in July and August. The name Anagallis is the old Greek name, and is made up of ana, again, and agallo, to adorn. 


\section{Chickweed (Stellaria media). Plate 54 .}

To utilize a blank space we have printed the portrait of the lowly and ubiquitous Chickweed, a plant that has followed English pioneers wherever they have gone about the world. It is thoroughly known to all, but for particulars concerning it and the genus the reader is referred to page 62 .

\section{Fennel (Faniculum officinale).}

To see the Fennel in its native haunts we must seek the coast where there are cliffs, up whose face we shall find its tall, stout, jointed stems and umbellate flowers. In this plant we make acquaintance with an important Natural Order, the Umbelliferæ, which includes such useful plants as Celery, Parsley, Carrot, Parsnip, Asafoetida, Anise, Dill, Hemlock, etc. The prevailing characteristics of this order are: The stems are hollow ; the leaves, with few exceptions, are divided ; the leafstalk at its base expands and forms a sheath to the stem; the flowers borne on long stalks arranged like the ribs of an umbrella; the flowers five-parted, the ovary below the petals and stamens, and the fruit what is known as a cremocarp.

Fennel grows to a height of three or four feet, with a round and tubular, but almost solid stem, quite solid at the joints, and grooved. The leaves are so much divided that the divisions are merely many green threads. The flowers are individually minute, the petals yellow, but to give them greater prominence they are gathered into umbels, and these are arranged in umbels of umbels, or what botanists would term compound umbels.

The ovary consists of two carpels placed face to face, in each of which is a single seed suspended like a nut in its shell (pericarp). Each of the carpels with its ripe seed is termed a mericarp, and the entire fruit is a cremocarp. It is hard on the 


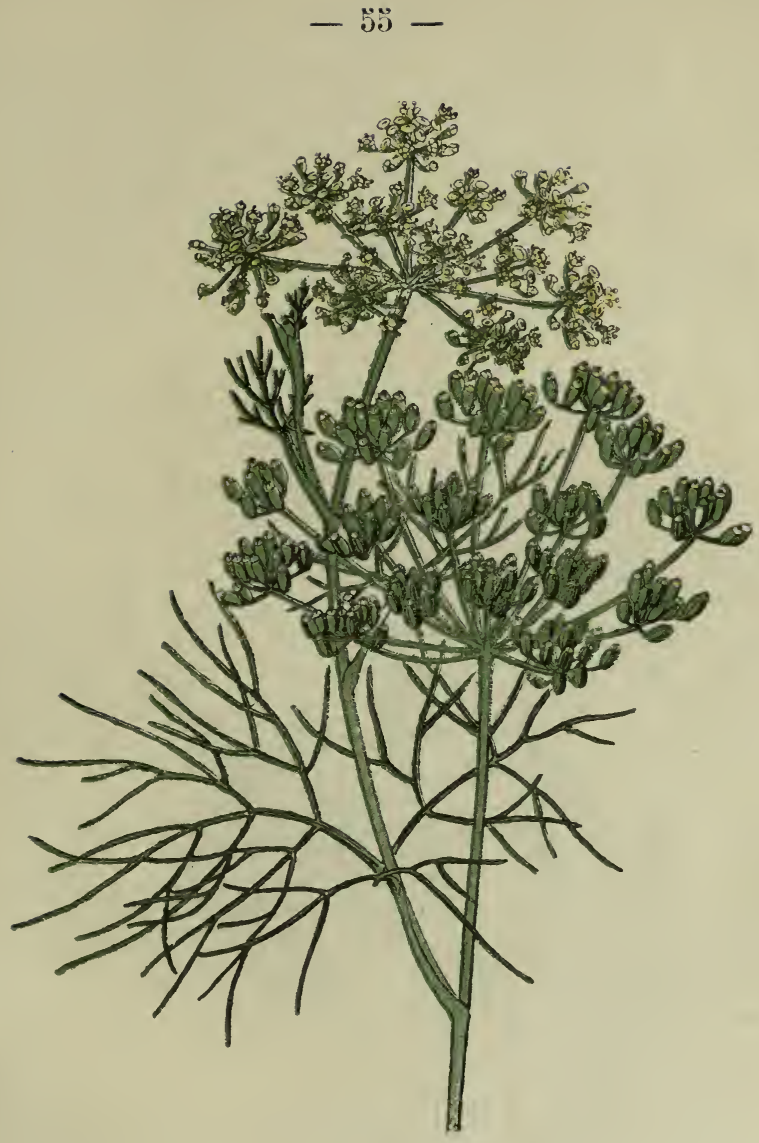

Fennel.

Fœniculum officinale.

- UMBellifer E. - 
$-56-$

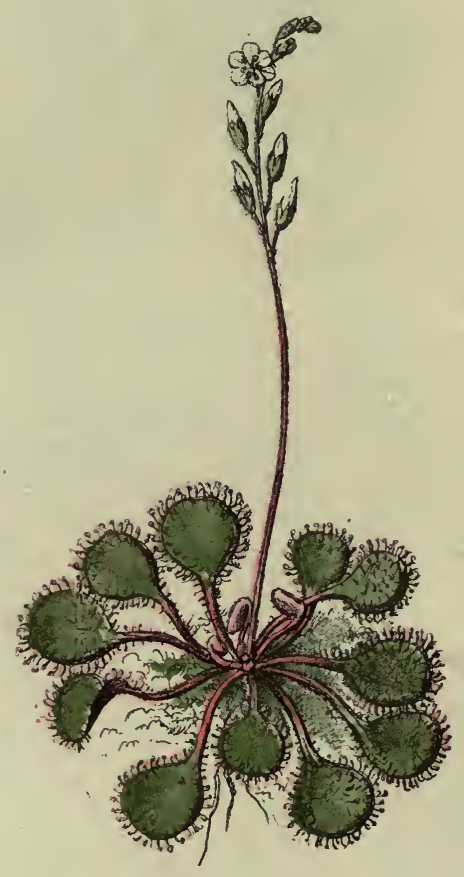

Round leaved Sundew.

Drosera rotundifolia.

- Droseracee. - 
reader to fling all these technical terms at him at once, but in truth there is no help for it. If he wishes to become acquainted with the extensive order of Umbelliferous plants he must constantly use these terms, for the fruits play an important part in distinguishing umbellifers of various genera.

The mericarps in Fennel are half-round, and marked on the outside with five ridges, which mark the lines of union of the sepals (which are adherent to the carpels) and the central keels of the sepals. Between these ridges are tubes (vitta) containing essential-oil, and it is to their presence that fruits of this order owe their aromatic qualities.

\section{The Round-leaved Sundew (Drosera rotundifolia).}

The Sundews, of which we have three native species, must be sought out, for they seldom obtrude themselves on the attention of those whose eyes have not been trained to see them. They must be looked for in peat bogs, and in hollows on sandy heaths, where they grow in crowds. The leaves of $D$. rotundifolia arise from a slender rootstock, and lie on the ground in the form of a rosette, from the centre of which the tall slender flower-stalks appear in July and August. Each leaf bears near the upper margins several rows of long crimson glands, terminating in rounded heads, and reminding one of a sea-anemone's tentacles ; indeed, they serve a similar purpose. These glands secrete a clear sticky fluid, which serves to detain small insects that crawl over the leaf. Their efforts to free themselves irritate the glands, which all bend over to the insect ; at the same time the margins of the leaf-blade begin to become incurved, and the insect is effectually secured in the hollow, ultimately being digested and the soft parts assimilated by the plant. Readers desiring to learn more of these curious habits of the plant are advised to grow it in a saucer of peat, and to read Mr. Darwin's celebrated work on "Insectivorous Plants." 
The leaf in this species, as its name signifies, has a round blade, and this is attached to a long hairy leaf-stalk. In the Narrow-leaved Sundew (D. intermedia) the blade is spoonshaped, and merges insensibly into the smooth leaf-stalk. In the third species, or Long-leaved Sundew (D. anglica) the entire leaf is similar to that of intermedia, but twice the length. In neither of the long-leaved species are the leaves laid flat as in rotundifolia; those of intermedia are erect, whilst those of anglica are borne half-erect. D. anglica is rare in the South of England; the others are well distributed. The name is derived from the Greek, Drosera, dewy, in allusion to the bedewed appearance of the leaves.

\section{Barberry (Berberis vulgaris).}

The Common Barberry is a spiny shrub, growing in hedge and copse, and brightening the spot from April to June with its strings of yellow flowers, and later in the year with its oblong red berries. Its shoots attain a height of from six to eight feet, and are clothed in a whitish bark, the wood being yellow. The flowers include eight or nine sepals and six petals : the outer sepals are very small and liable to be overlooked. The petals are in two series, and at the base of each petal are two honeysecreting glands, which induce the visits of honey-loving insects. There are six stamens, which ordinarily lie along the centre of the petals, their bases highly irritable. In an open flower like this any insect can get at the honey, but it is not easy to do so without touching the base of one of the stamens; on this being done the stamen springs forward, and the anthers strike the insect, dusting it with pollen, and in some cases driving it away. This mechanism may be tested by touching the base of a stamen with the point of a pin.

The Barberry is very liable to the attacks of a minute fungus, a stage in the development of wheat-rust (Uredo graminis). The name Berberis is the Arabic title of the plant. 


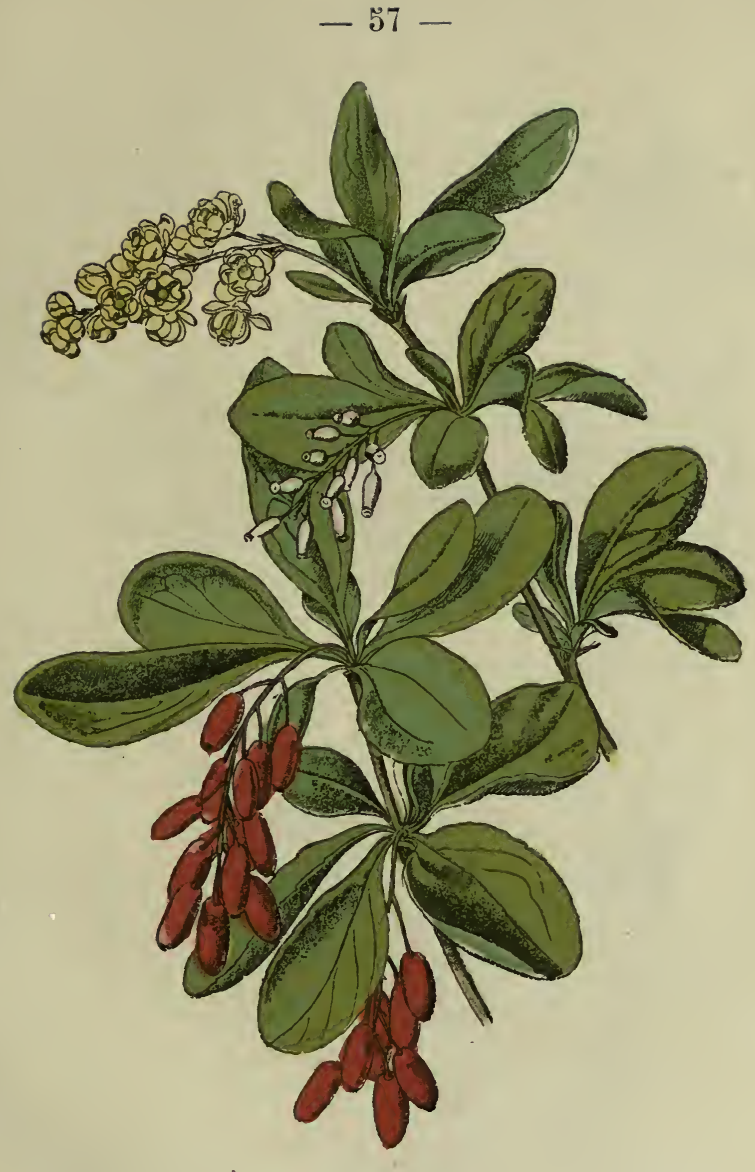

Barberry.

Berberis vulgaris.

- Berberine A. - 

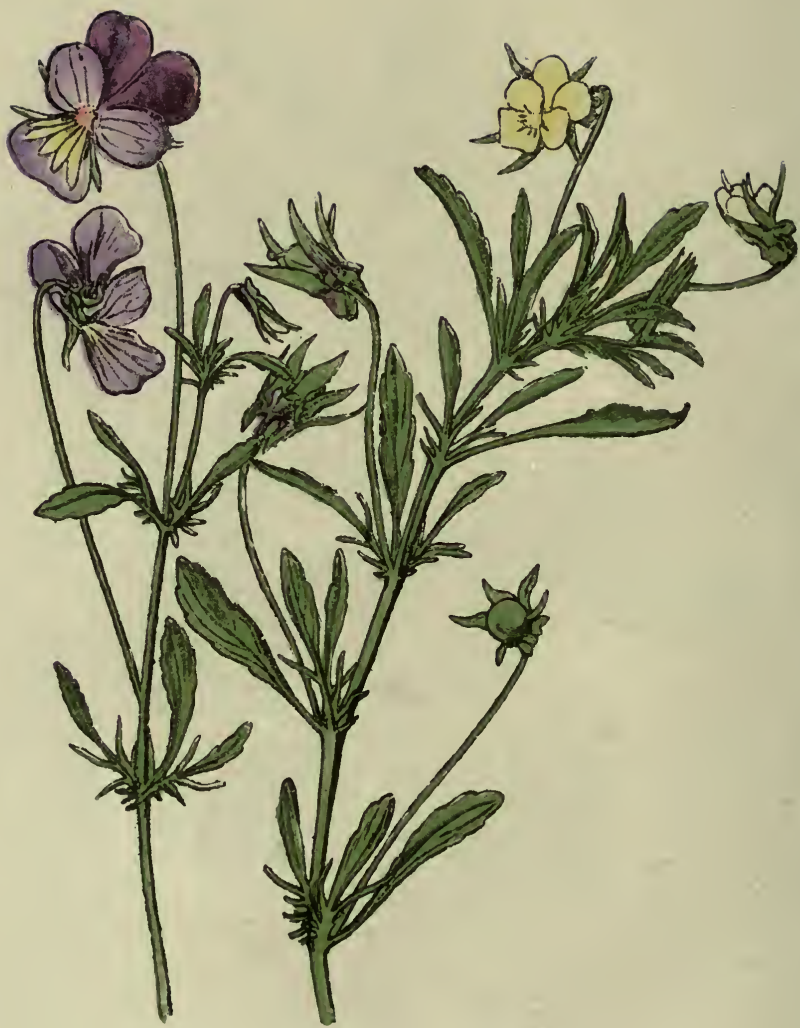

Wild Pansy.

Viola tricolor.

- Violacez. - 


\section{Wild Pansy (Viola tricolor).}

We have already given the general characters of the Violet family on page 4 , where the reader was referred to this page for a notice of the British species other than $V$. odorata. The present species, $V$. tricolor, differs from all the others in the fact that the two upper petals are very erect instead of leaning forward, and in the stipules being developed into large leaf-like organs. In addition, this species produces none of the cleistogamous flowers. The leaves, too, assume forms very different from those of the typical species. The flowers vary from white, through yellow to purple, or there may be a mixture of two or more of these tints. They grow in pastures and the waste corners of various fields, flowering from May to September, and are geherally distributed. The other species are :-

I. Marsh Violet (V.palustris). Growing among Sphagnum in bogs. Flowers lilac or white, scentless, and with short blunt spur. April to July.

II. Hairy Violet $(V$. hirta). Similar to $V$. odorata, but more compact, more hairy, the leaves narrower and more deeply toothed; spur long, hooked. Odour slight or wholly wanting. A local species occurring in dry soils. April to June.

III. Dog Violet ( $V$. canina). Rootstock produced into a distinct stem, bearing flowers. Sepals narrow, pointed. Leaves not enlarging after flowering, as do thuse of $V$. odorata, palustris, and hirta; on long fout-stalks. Plant more or less smooth. Flowers from April to August, on banks everywhere.

IV. Wood Violet (V. sylvatica). Plant smooth. Central rootstock short, with a rosette of leaves, from which branches are given off all round. From these branches only are flowers produced. Spur short and broad. Leaves broad. Copses and woods. March to July. Often closely resembling $V$. canina, of which it may be only a variety.

V. Sand Violet ( $V$. arenaria). A very rare, compact, hairy plant. Leaves much rounder than the preceding. Petals broad, pale blue. Spur short. Recorded from Upper Teasdale and Westmoreland only; flowering in May and June.

\section{Round-leaved Mint (Mentha rotundifolia).}

Everybody knows a Mint when he comes upon it, by reason of its pungent odour, well represented by Spear-mint (Mentha 
viridis), the cultivated herb of kitchen gardens. Spear-mint is held to be only a naturalized, not a native species, unless it be in one corner of our country-West Yorks. We have, however, seven species that may be set down as natives, but they are a rather troublesome group for the botanical student; there are so many varieties, hybrids, and sub-species, which tend to connect the species and make it difficult to determine the identity of some specimens. With the exception of the Cornmint ( $M$. arvensis), they are all inhabitants of wet and marshy wastes, flowering in August and September. They are Labiate plants, and therefore the reader will know what type of flower to expect (see pages $2 \mathrm{I}$ and 23 ante). These flowers are individually small, but rendered more conspicuous by being borne in dense whorls, the whorls being often so many and so close together as to form long spikes of bloom. They are all perennial herbs, with square stems and rootstocks, the latter creeping on or just below the surface of the ground, and giving off runners freely. Mentha rotundifolia has broadly ovate, wrinkled, stalkless leaves, the edges indented with rounded teeth, and woolly on the underside. Flower-spikes dense, though with slight intervals between the whorls. The colour of the flowers varies from pink to white. The other species are :-

I. Horse-Mint (M. sylvestris). 'Leaves stalkless, more tapering to a point than in $M$. rotundifolia, smooth above, sharply toothed, whitish beneath. Stem covered with white woolly hairs. Flowers lilac, spike continuous. Rare.

II. Peppermint (M. piperata). Leaves stalked, margins with large teeth, smooth above, a few hairs along the nervures underneath. Flowers purplish in spikes.

III. Water-Mint (M. aquatica). A very common form in marshes and by riversides, covered with soft hairs. Stout spikes, lilac or purple. Leaves stalked.

IV. Marsh-mint ( $M$. sativa). In this and the two following species the whorls are produced from the axils of the leaves instead of as a terminal spike. The leaves are stalked, with sharp teeth. Flowers purplish. The throat of calyx smooth, calyx-teeth lance-shaped, ending in a fine point.

V. Corn-mint (M. arrensis). Leaves with blunt teeth. Calyx very hairy, teeth shorter than in last, triangular. Corolla hairy, purplish. Cornfields and waste places. 
$-59-$

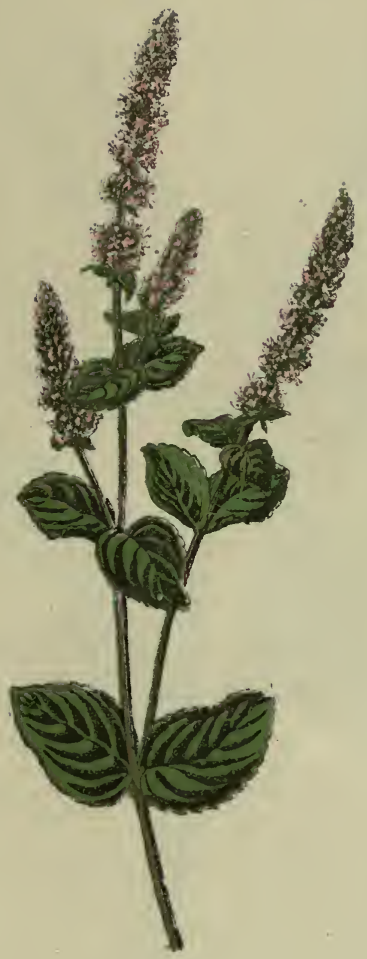

Round leaved Mint.

Mentha rotundifolia.

- LabiaTæ. - 
$-60-$

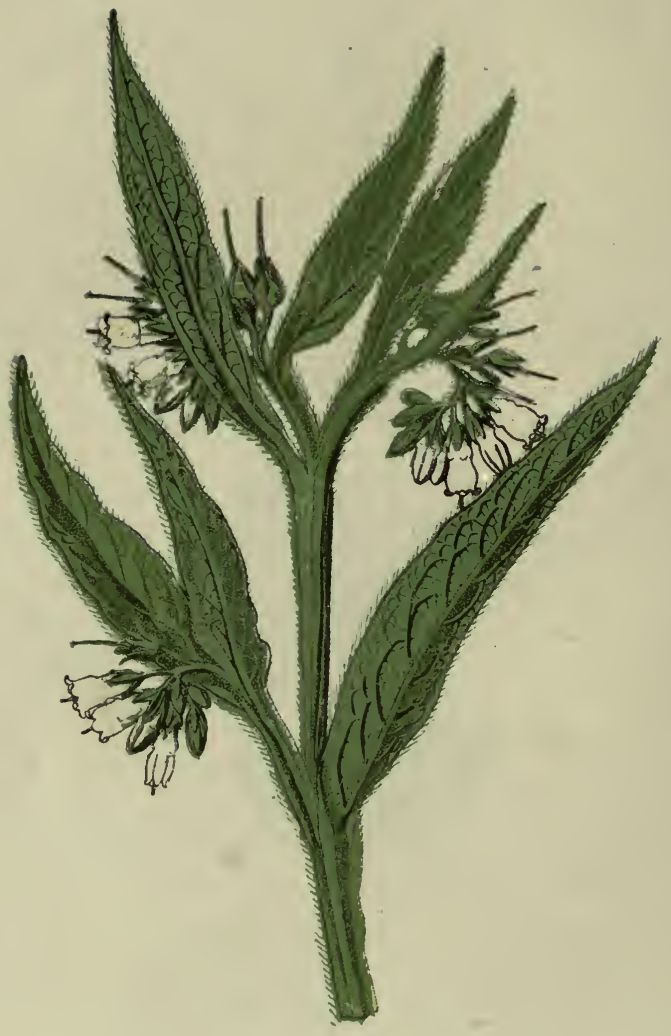

Common Comfrey.

Symphytum officinale.

- BoragineA. - 
VI. Pennyroyal (M. pulegium). Calyx two-lipped, downy or hairy, with hairy throat. Leaves small, with short stalks, slightly toothed, recurved. Stem muchbranched. Odour powerful.

\section{Common Comfrey (Symphytum officinale).}

Often in May and June, as we wander by the riverbank or brookside, we shall happen upon this very coarse but striking plant, though its flowers may not be of the hue depicted here ; its colour varies from pale yellow to red and purple. It is one of those plants whose individuality is so strong that, once seen, it will not be forgotten or confused with any other species. It has a branched rootstock, giving off stalked leaves, and an erect angular stem. The stem-leaves are all but stalkless, their bases running down the stem in such a manner as to give it a winged character. The whole plant is rough with bristles. The genus belongs to the order Boraginex, whose floral structure has been already described (see pages 9 and 26 ante), but the present inflorescence may be noted as a capital example of the "scorpioid cyme," so called from its curve resembling the curl in a scorpion's tail!

There is another British species, the Tuberous Comfrey (S. tuberosum), which is usually found in wet copses, but not south of Bedford. It is not nearly so rough as its congener, although distinctly hairy. Rootstock thickened, radical leaves with longer stalks than in S. officinale. The stem-leaves do not run far down the stem, so that it is not so obviously winged, and the flowers are smaller. Pale yellow. June and July.

The name is derived from the Greek sumphuo, to unite, it having great reputation formerly as a woundwort.

\section{Common Red Poppy (Papaver rhaas).}

The Poppy is another of those plants concerning which it may be thought that neither illustration nor description is necessary ; but there are poppies and poppies ; and though the rambler may gather a bunch of flowers from various situations and consider them all the same, a few words of description may serve to point out considerable differences. 
Through the Poppy we make acquaintance with another Natural Order, the Papaveraceæ, and its typical genus, Papaver. The plants comprised in the genus are annual herbs, with milky juice of a narcotic nature. The flowers are borne on very long slender stalks, and consist of two concave sepals, which are thrown off by the expanding of the four crumpled petals. The pistil, which afterwards develops into the familiar "poppy-head," is surmounted by the many stigmas which form a rayed disk.

I. The Common Poppy ( $P$, rhoeas), which is so unpleasantly abundant in cornfields south of the Tay, has branched bristly stems and pinnate leaves, the points of the lobes directed upward and ending each in a bristle. The bristles on the flowerstalks stand out at right angles, or nearly so. This is an important character. The scarlet flowers are large ( 3 or 4 inches in diameter), the petals in two unequal pairs. Rays of stigma eight to twelve. Capsule smooth and short, slightly stalked above the receptacle. Flowers June to September.

II. Round Rough-headed Poppy ( $P$. hybridum). Leaves only slightly bristly. Flower small (I to 2 inches), scarlet, with a black patch at the base of each petal. Stigmatic rays, four to eight. Capsule more globose than the preceding species. Dry sandy and chalky fields south of Durham and Carnarvon. May to July.

III. Long Prickly-headed Poppy ( $P$. argemone). Similar to last, but smaller and weaker in all respects-in fact, our smallest species. Petals narrow and paler in colour. Capsule bristly, club-shaped. Stigmatic rays, four to six. Cornfields. May to August.

IV. Long Smooth-headed Poppy $(P$. dubium). Similar to $P$. rhoeas, but the bristles are pressed against the stalk upwards. Flowers large, petals broad, but in unequal pairs, light scarlet. Stigmatic rays, six to twelve. Capsule slender, smooth, tapering downwards, not stalked above receptacle. Cornfields. May to August.

\section{The Greater Stitchwort (Stellaria holostea)}

One of the prettiest and most characteristic sights of Spring is the mass of brittle, grass-like stems and leaves of the Greater Stitchwort, crowned by the numerous flowers of gleaming white clear-cut stars. It starts life as an erect-growing plant, but is soon fain to lean against the other constituents of the hedgerow as its stems elongate but grow no stouter. It is a perennial plant, and its four-angled stems make their appear- 
$-61-$

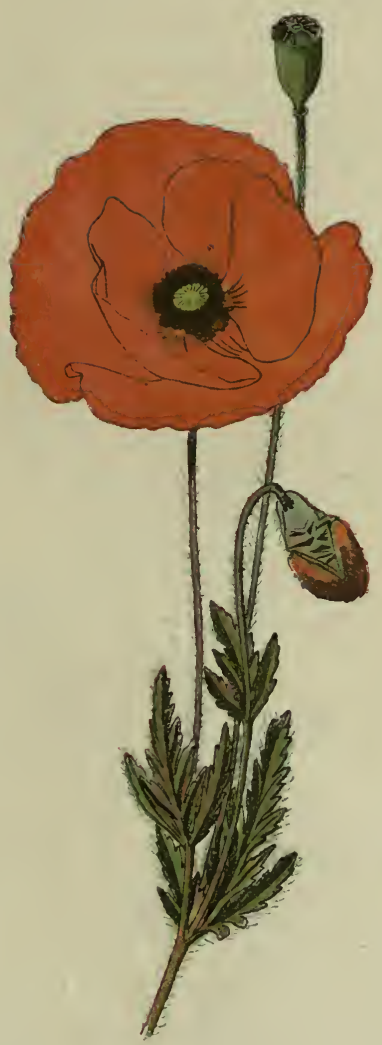

Red Poppy.

Papaver rhœas.

- Papaveraceze. - 
$-62-$

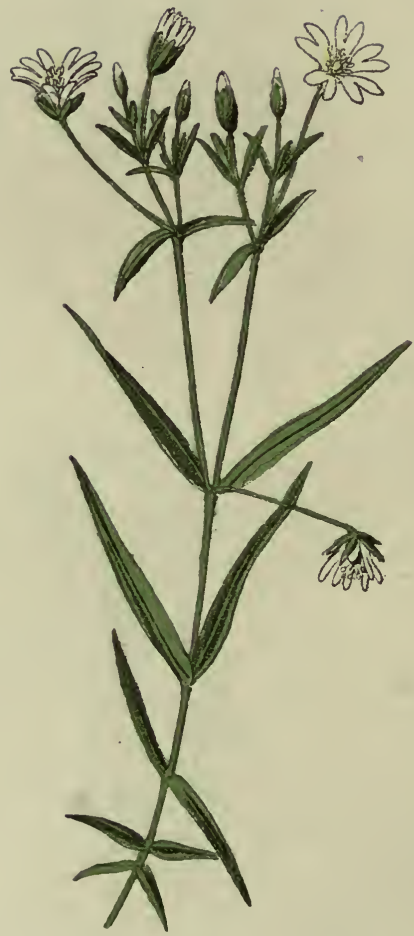

Greater Stitchwort. Stellaria holostea.

- Caryophyllez. - 
ance very early in the year. The long, narrow, rigid, sharppointed leaves are arranged in pairs, which are more or less connected at their bases. The flowers are produced in a panicle of a few flowers only, which consist of five almost nerveless sepals, five petals which are as long again as the sepals and cleft almost to the middle. They are succeeded by a globose capsule containing many seeds. There are ten stamens and three styles. Flowers April to June.

The genus Stellaria is included in the Natural Order Caryophylleæ, or the Pink tribe, of which we shall have further examples.

I. The Lesser Stitchwort (S. graminea) is a similar, but much more slender plant, with exceedingly narrow leaves, smaller flowers arranged in a much-branched panicle, and with red anthers. After flowering the flower-stalks hang downwards, but afterwards rise to a horizontal position. The sepals are as long as the narrow petals, united at their bases, and have three nerves. Capsule nodding. Flowers May to July.

II. The Marsh Stitchwort (S. palustris). Smooth, with a fine bloom (glaucous). Sepals united at base, three-nerved, not so long as the petals. Flowers solitary on long stalks. Marshes and wet places. May to July.

III. The Common Chickweed (S. media), which we have already figured (plate 54 ante), is also a member of this genus. The stem trails along the ground, is very brittle and marked with a line of fine hairs up one side. The flowers are inconspicuous, on account of the sepals being longer than the petals, which are, in fact, often absent altogether. It grows everywhere, and may be found flowering throughout the year. It has followed the Englishman wherever he has gone about the earth.

The name of the genus is from the Latin, Stella, a star, in reference to the starlike character of the blossoms.

\section{Silverweed (Potentilla anserina).}

The beautiful but too common Silverweed may be taken as a good representative of a genus of Rose-worts that may be conveniently called Cinquefoils, although the leaf of this species has many instead of five divisions. This is the plant that grows in dense patches by the roadside, erecting its long pinnate silky leaves and showing the silvery-greyness of the underside. Its rootstock is the centre from which many rooting runners radiate. The toothed leaflets are not opposite, 
as may appear at first sight, but alternate ; and there is the very peculiar arrangement of two minute leaflets being placed between each two large ones. The flowers are large in proportion to the plant, of one uniform yellow, and borne singly on a long stalk. The calyx is cleft into ten lobes, the petals are five, stamens and carpels many. Although it is a common roadside weed, it may also be met growing abundantly and much more luxuriantly in wet pastures. It flowers chiefly from June to August, and sparingly much later in the year.

Among its more immediate congeners may be noted :-

I. The Tormentil $\left(P_{0}\right.$ tormentilla $)$, a tiny plant that is abundant on heaths and dry pastures. It has a thick rootstock, and slender, hairy, creeping stems. The leaves are cut into three, sometimes five, fingers, which are more or less wedgeshaped, the free end lobed or toothed. Flowers yellow, and similar to those of $P$. anserina, but smaller, and usually with only four petals. June to September.

II. Creeping Cinquefoil ( $P$. reptans). Similar to $P$. tormentilla but larger. Leaflets five, sometimes three, petals five. Meadows and waysides. June to September.

III. Barren Strawberry ( $P$. fragariastrum). Flowers white. March to June. The general characters of this impostor have been given on page 27, when describing the Wild Strawberry. The plant has a general silkiness which is foreign to the strawberry.

The name of the genus is from the Latin, potens, powerful, some of the species having formerly considerable reputation as medicines.

\section{Small Bindweed (Convolvulus arvensis).}

With the appearance of the delicately fragrant Bindweed in our fields the season for summer flowers may be said to have fairly set in. Its grace of form and colour makes it a general favourite, but it resents being plucked, and closes its pink cups almost immediately. It has a perennial rootstock, which creeps and branches underground, taking possession of much soil, and sending up many slender twining stems clothed with spearshaped leaves. The sepals are five in number, but the petals are entirely united to form a funnel-shaped corolla; though the five folds and lobes indicate the origin of the funnel. The flowers 


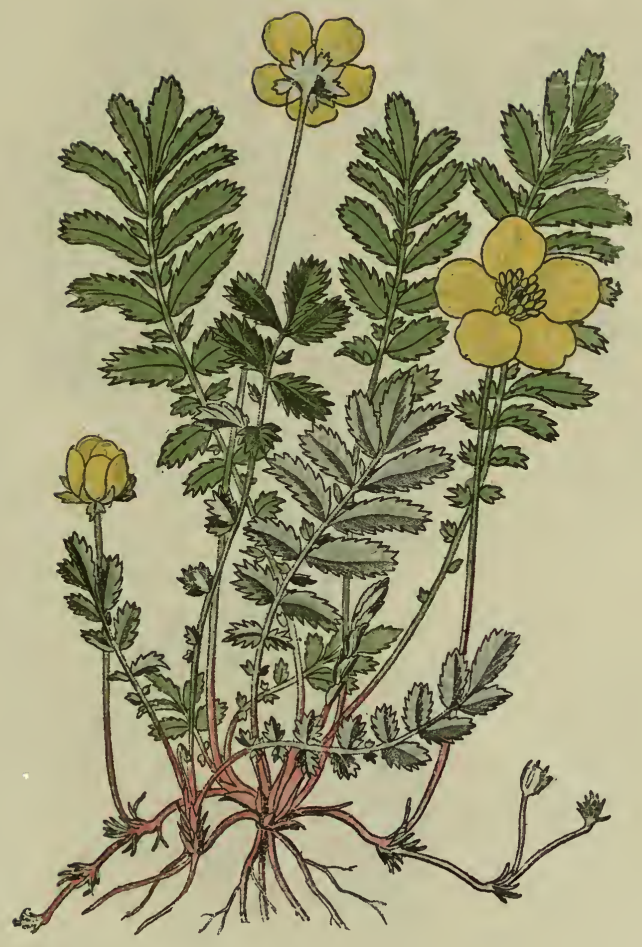

Silverweed.

Potentilla anserina.

- ROSACEA. - 
$-64-$

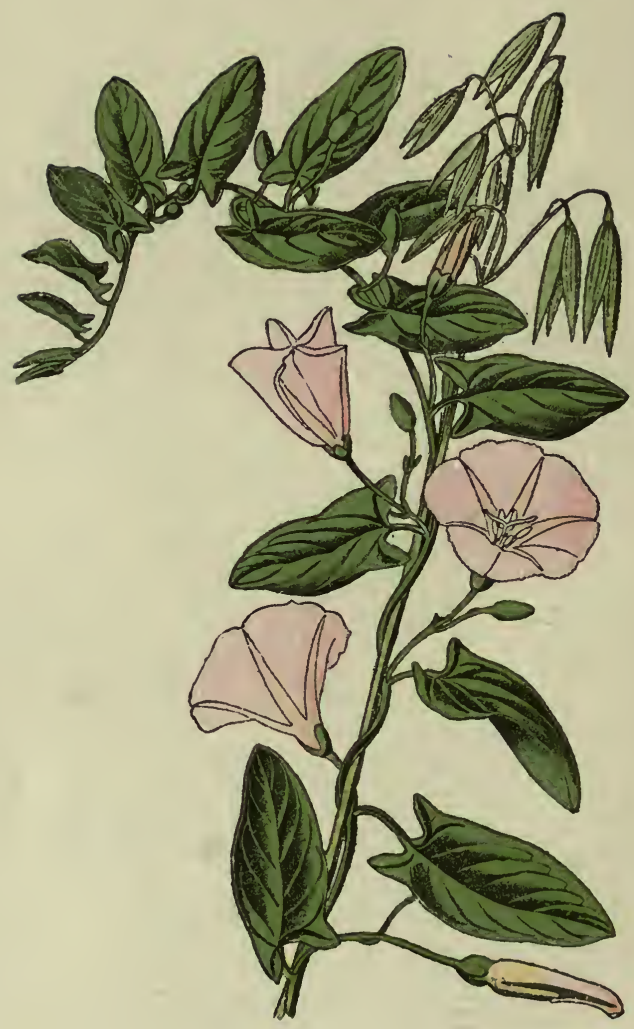

Small Bindweed.

Convolvulus arvensis.

- Convolvulace e. - 
are honeyed, and are much frequented by long-tongued insects, which have to push against the anthers in order to reach the honey, carrying away pollen with which to fertilize another flower. Like a careful, thrifty plant the Bindweed closes in wet weather, and at night, that its honey may not be reduced in quality. It flowers from June to September.

The Hooded Bindweed ( $C$. sepium) is one of the most distinguished of our wild flowers, and it is almost impossible to see its large, pure white flowers ornamenting the hedge without desiring to acquire them. In general form it is like $C$. arvensis, but very much larger. Instead of being content to twine among low-growing herbs as that species, it climbs up the thickets to a height of 6 or 7 feet. In addition to the calyx this species has an enveloping pair of large inflated heart-shaped bracts -the "hood" of its popular name. The rootstock is thick and tuberous. Though it possesses honey it is not odorous, and appears to be, in consequence, but little visited by insects ; it is, therefore, careless of the quality of its honey, and does not close its flowers in the rain, nor on moonlight nights, though it does so on dark nights. Sometimes the flowers are tinged or streaked with pink. Flowers June to August.

There is a third native species, the Seaside Convolvulus (C. soldanella), which does not twine, or but rarely. It has a long creeping rhizome, slender stems, and fleshy, kidney-shaped leaves. Its large rosy flowers are not numerous. There are two bracts, as in $C$. sepizm, but they are smaller than the unequal sepals. It may frequently te found on sandy shores, and flowers from June to August.

\section{The Greater Celandine (Chelidonium majus).}

We have already described (page 6 ante) a plant bearing the name of Lesser Celandine, and we would at once warn the reader that the Greater Celandine is not even distantly related to the Lesser. Here is an illustration of the dangers that arise from dependence upon the folk-names of plants and animals. The novice would reasonably assume that the Lesser and the Greater Celandines differed only in point of size, whereas the resemblance that struck our forefathers appears to have consisted merely in both plants being in flower what time the swallow (Chelidon) returns to our shores. Chelidonium majus is really a kind of poppy, whilst Ranunculus ficaria is a buttercup.

There is only one British species of Chelidonium, a perennial 
plant, with erect branching stems. The true poppies have a milky juice: this plant, like the Welsh-poppy (Meconopsis), and the Horned-poppy (Glaucium) has a yellow juice. The leaf is much divided, the leaflets deeply lobed, with somewhat of a resemblance to an oak-leaf. The rather small yellow flowers are combined in umbels, borne on a long stalk, to be out of the way of the somewhat erect leaves. There are two sepals and four petals, as in Papaver, but the fruit, instead of being an urn-like capsule as in that genus, is a long pod with two valves, which separate from the base upwards.

It is a plant of the hedgerow and waste ground, where it may be found in flower from May to August. The yellow juice, which is very acrid and poisonous, had formerly a reputation as an eye medicine, and as a caustic for the burning away of warts.

\section{Ragged Robin (Lychnis flos-cuculi).}

Like the Celandines, this plant was known to our fathers as a Cuckoo-flower; in fact, in many parts of the country its name is still "Cuckoo-flower," but as that title is also given to the Ladies'-smock confusion is caused by its use. It is one of the Campions, a genus of graceful plants that, is included in the Natural Order of the Pinks (Caryophylleæ).

The habit of the plant will suggest the Stitchwort, to which it is not very distantly related. It is a perennial plant, delighting in moist places, whether wet meadows, ditch banks or bogs. The leaves that spring directly from the slender rootstock are stalked; those on the reddish stem are not. The calyx is dark red, with purple veins; tha rosy petals cut into four eccentric narrow segments. The flowers produce honey, and the stamens come to maturity before the stigmas, thus favouring cross-fertilization. Flowers May to August.

There is another common rosy-flowered Lychnis that occurs in somewhat similar situations. This is :- 
$-6 \Xi-$

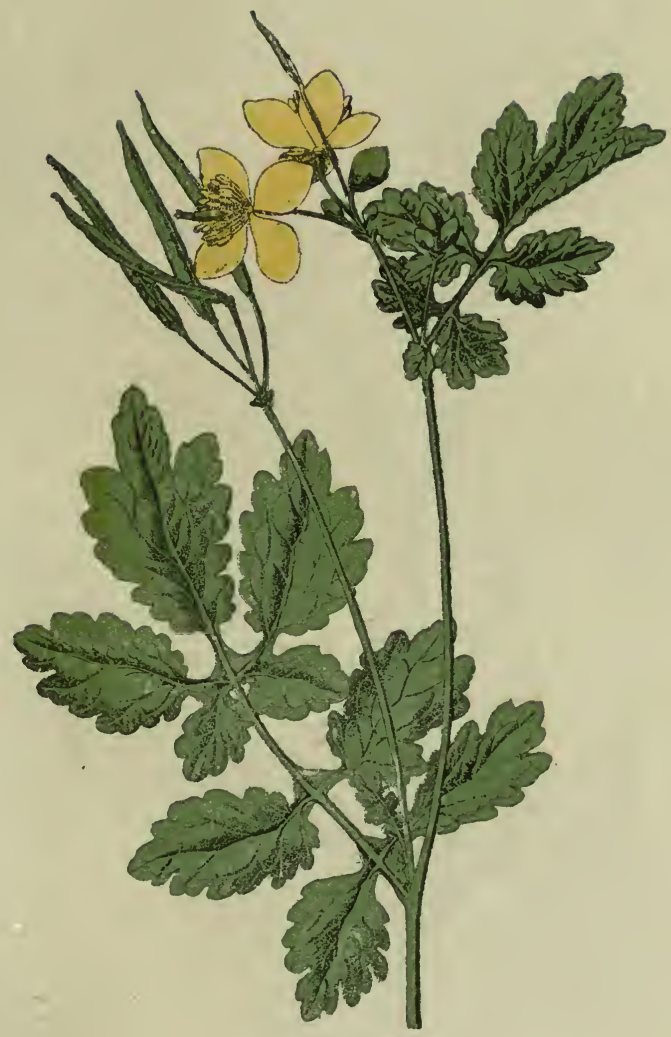

Celandine.

Chelidonium majus.

- Papaverace天. - 
$-66-$

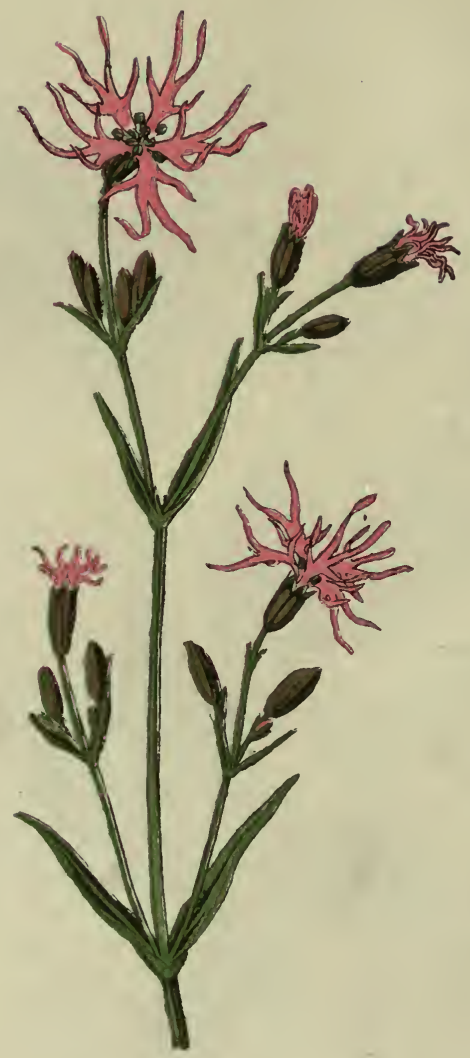

Rugged Robin.

Lychnis flos-cuculi.

- Caryophylle.z. - 
The Red Campion (Lychnis diurna), with stem covered with soft hairs, which are sticky near the upper part of the plant. The flower has a singularly neat appearance, altogether lacking the ragged character of flos-cuculi. The petals, instead of being deeply cut, as in that species, are merely divided into two lobes. The calyx is reddish, with triangular teeth. The anthers and stigmas are produced in separate flowers; occasionally flowers may be found with both organs, but one or the other will be undeveloped.

The Red Campion is a plant of the hedge-bank and the copse, where it may be found in flower from June to September. In Cornwall it keeps fully in flower till the end of the year. This page was written there a few days before Christmas, when the fern-clad rocky hedgerows were lit up with great numbers of the flowers of Red Campion and Herb-Robert.

The name Lychnis is from the Greek, Luchnos, a lamp or torch, the application of which is obscure.

\section{Bluebottle or Cornflower (Centaurea cyanus).}

The Centaureas are closely allied to the thistles, and share with them that hard-headedness which makes the thistle so good a type of the canny Scot. The Bluebottle must not be sought in the company of the thistles on wastes and in neglected corners of pasture, but, as one of its folk-names indicates, in the cornfield. Beginning to flower in June, it keeps up the display of bright blue until the reapers cut it down.

Bluebottle is a composite flower, and it should afford interest to the reader, when he finds the blossoms, to institute a comparison between it and that of the Daisy or other of the Composites we have already described.

The thin stem is but slightly branched, and the long lower ieaves are much cut up and very attenuated. Nearer the summit of the stems the leaves are simpler, and reduced to a very slight width. The stems and the under sides of the leaves are covered with loose cottony fibres. The flower-heads have for involucre a number of greenish scales, with toothed brown margins. The ray-florets are bright blue, their free ends divided into five teeth; the inner or disc-florets are much darker. The stamens are irritable, and if touched withdraw into the tube. 
There are five other British species of Centaurea, of which several are rare or extremely local in their distribution. The more frequent species are :-

I. Black Knapweed ( $C$. nigra). Leaves rough, entire or lobed, the lower ones with stalks. The heads large and globose, as much as an inch and a half in diameter. Involucral scales circular, brown, toothed. Florets purple. Common in meadows and pastures. June to September.

II. Greater Knapweed, or Hard Heads (C. scabiosa). The leaves are deeply pinnate, like the lower ones of Bluebottle. Heads as much as two inches diameter. Involucral scales cottony, with dark brown, almost black, margin, and paler fringe. Florets rich purple. Waste places. July to September.

\section{Round-leaved Mallow (Malva rotundifolia).}

The Round-leaved or Dwarf Mallow is not so well known as the Common Mallow ( $M$. sylvestris), though it is nearly as common. Its flowers are small, and not nearly so conspicuous as those of sylvestris. Like that plant it is found growing by the wayside and on waste places where garden refuse, etc., is dumped. Our three species of Malva are all perennials, and all possess tough fibrous stems. Those of rotundifolia are downy, and lie along the ground and bear many lobed, often toothed, leaves, whose general outline is circular. The flowers are clustered in the axils, and consist of a five-parted calyx, to which is attached a kind of involucre of three bracts, and five distant petals, their tips with a central notch. There are ten styles, the inner surfaces of which are stigmatic ; they curl about in various directions, mingling with the numerous anthers, and so ensuring self-fertilization. The fruit consists of a large number of one-seeded carpels arranged in a circle, but easily becoming detached after ripening. Flowers June to September.

The other species are :-

I. Common Mallow (M. sylvestris). Its stems are erect, somewhat hairy. Leaves more distinctly lobed. Flowers large, the petals heart-shaped, pale purple (mauve). The anthers mature before the stigmas, unlike $M$. rotundifolia, where both organs 


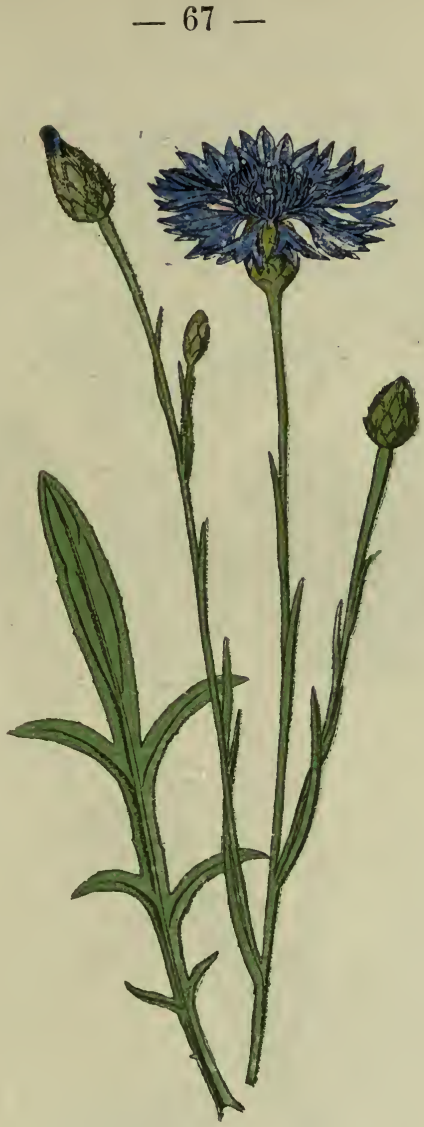

Cornflower. Blue-bottle.

Centaurea cyanus.

- Composite. - 
$-68$

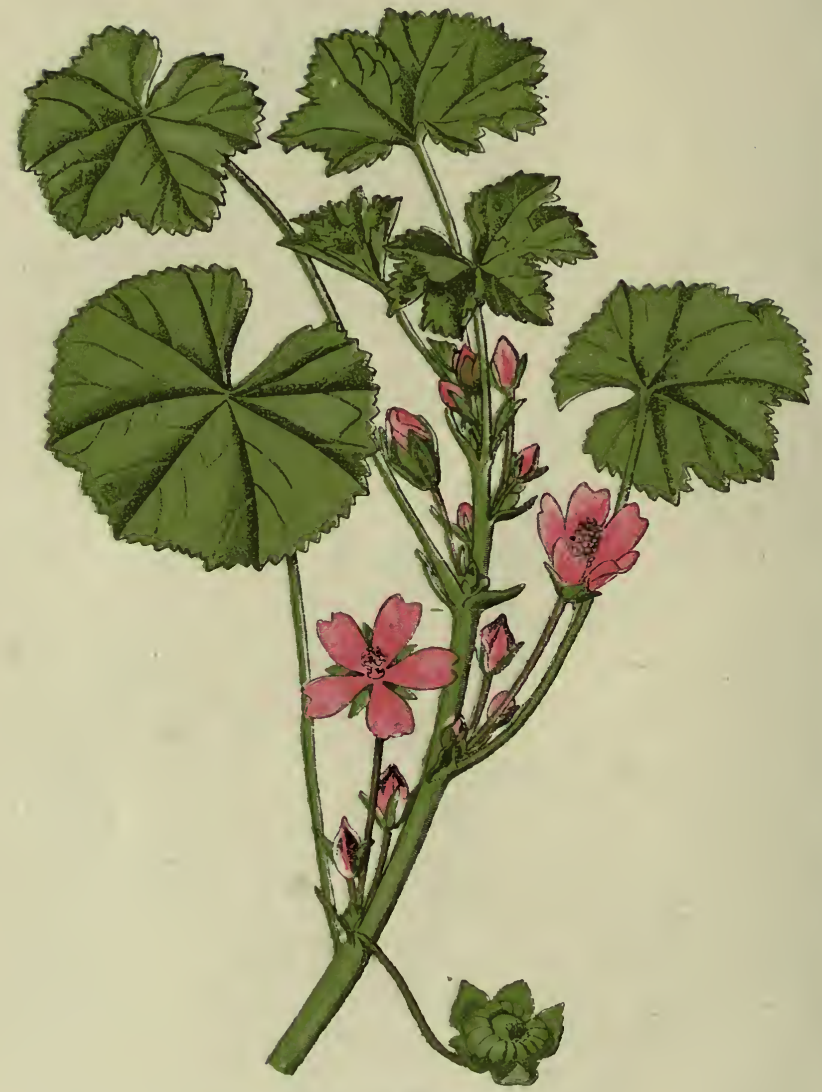

Dwarf Mallow.

Malva rotundifolia.

- Malvace.e. - 
mature at the same time. This brings out an interesting point in their relations to insects, as shown by H. Müller. The styles, instead of mingling with the anthers, hold themselves strictly above the drooping stamens, and self-fertilization is impossible. To secure cross-fertilization the flowers are large, and more showy than in rotundifolia, and attract many insects, which bring and carry pollen. June to September.

II. Musk Mallow ( $M$. moschatus). Flowers not quite so large as the last, rosy, clustered at end of erect stems. Leaves divided into five to seven segments, which are nearly pinnate. Very slight odour of musk when the leaves are passed through the hands. Dry meadows and hedgerows. July and August. The Marsh-mallow belongs to another genus (Althaa).

\section{Chicory or Succory (Cichorium intybus). Plate 69.}

The Wild Chicory is peculiarly a plant of the dry roadside, especially in chalky districts, where it is a striking feature. The rigid erectness of its stems is not pleasing, but the bright, paleblue flowers, attached to the stem without the intervention of flower-stalks, arrest attention. Its thick, fleshy tap-root is the substance that, when roasted and ground, bulks so largely in "The finest French Coffees, as sold in Paris," of our grocers. For this purpose it is cultivated on a large scale in Germany and Belgium:

If reference be made to the figure of the Dandelion on page 20 it will be seen that there is considerable resemblance between the leaves of the two. The radical leaves of Chicory spread themselves out, rosette fashion, upon the ground; the few that are scattered alternately up the somewhat hairy stem clasp the latter with the two lobes at their base. The flowers are usually in pairs. The involucre consists of two series of bracts, the outer row being reflexed, and shorter than the inner. The tubes of the ray-florets are split open, so that the rays are broad and strap-shaped, with a straight end notched into five teeth. It flowers from July to October.

The generic name is from an old Greek name for the plant, and a similar word is in use in nearly all the languages of civilization. 


\section{Yernal Wood-rush (Luzula vernalis).}

The Rushes as a whole (Juncus and Luzula) form a group of plants that is generally despised, except for weaving into mats, and, in other days, for providing wicks for rush-lights. We have in the one genus cylindric, in the other flattened grass-like, leaves, and inconspicuous flowers of green or brown; and yet the evolutionists tell us on the evidence of those flowers that the rushes are descendants of a noble family-the lilies-who have in the struggle for existence taken to a less showy rôle in life, in order that that they might be included in the list of the surviving "fittest." The truth of this will be apparent if we take the flower of a present-day lily-a tulip or a tiger-lily will do-and compare it with this Vernal Woodrush. We shall find every part of the lily reproduced in the rushflower on a small scale, with the greatest economy of materials.

The Wood-rushes (Luzula) are all perennial plants. Their leaves are like the blades of soft grass, the edges fringed with long white silky hairs. The floral leaves (perianth) are six in number, in two series, and are chaffy in texture. Stamens six. The ovary is broad, narrowing to the summit, upon which is the style, ending in three long stigmas covered with minute raised points. The fruit is a one-celled, three-valved capsule, containing three seeds at the bottom. In $L$. vernalis the flowers are chestnut brown, with the perianth-segments shorter than the blunt-topped capsule, and pointed at the tips; clustered in twos and threes and grouped in lax cymes. The radical leaves are broad ( $\frac{1}{4}$ inch), soft and sparingly hairy. Woods and shady places, flowering March to May. Other members of the genus are :-

I. The Great Hairy Wood-rush (L. maxima) is much larger, the leaves sometimes half an inch broad and a foot long, sparsely hairy. Flowers paler, three or four clustered; cymes large, compound. Woods and heaths. May and June.

II. Narrow-leaved Wood-rush (L. forsteri). Similar to L. vernalis, but more 
$-69-$

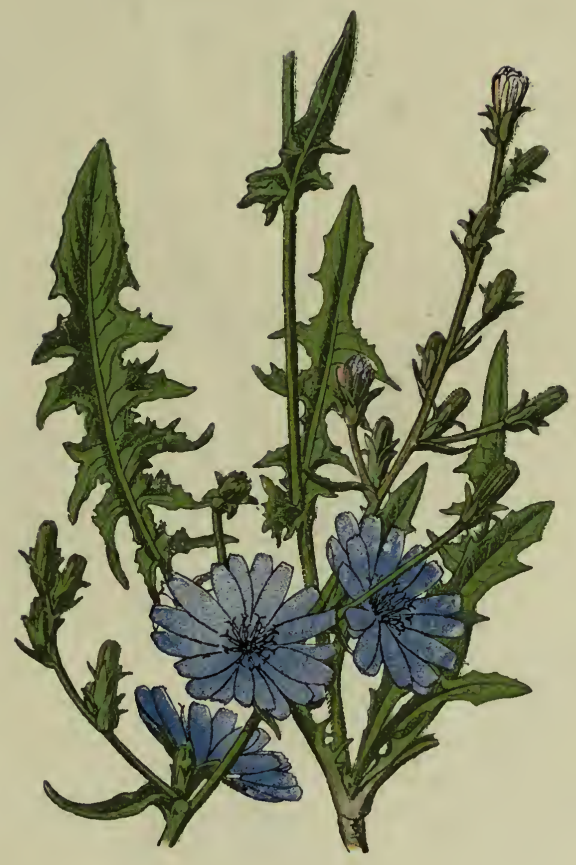

Chicory.

Cichorium intybus.

- Composita. - 


\section{$-70-$}

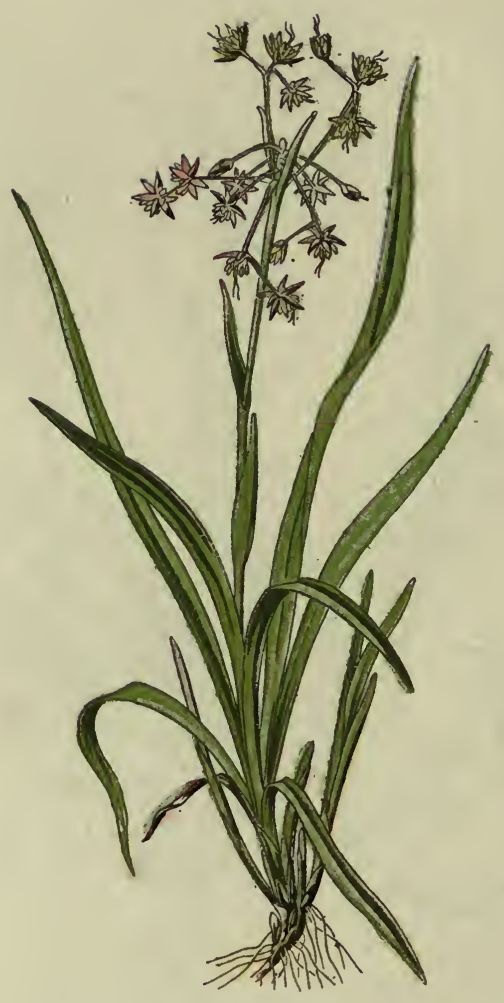

Broad-leaved Woodrush.

Luzula vernalis.

- JUNCE E. - 
slender and taller. Capsule pointed. Shady places on chalk or gravel, not farther north than South Wales and Oxford. April to June.

III. Field Wood-rush (L.campestris). Rootstock creeping. Leaves very hairy. Perianth segments longer than the broad rounded and spiked capsule. Flowers in dense clusters of three or four, in short cymes. Heaths and pastures. April to June.

IV. Spiked Mountain Wood-rush (L. spicata). This and the next are purely mountain species, restricted to an altitude of one to over four thousand feet for spicata, and from three to over four thousand for arcuata. The leaves are narrow, leathery, and the hairiness is confined to the lower end. Flowers smaller than the silvery, chaffy, awned scales (bracteoles) below them. The perianth segments end in awns, and are longer than the abruptly-pointed capsule. The cymes are densely flowered, drooping and spike-like. Flowers in July.

V. Curved Mountain Wood-rush ( $L$. arcuata). The smallest, rarest, and most distinct of our native species. The stems do not exceed about 4 inches, and are proportionately stout. Rootstock creeping. Leaves short, narrow, leathery, slightly hairy. Flowers dark brown, three to five in a cluster, in lax cymes; the perianth segments extended into a point. Bracteoles pointed, not awned, not silvery. Mountains in Scotland only. July.

\section{The Greater Dodder (Cuscuta europaca).}

There are two Dodders indigenous to this country, and we have the misfortune to have introduced a third with flax-seed from abroad. The one figured is the Greater Dodder, which is usually found clinging in a tangle round the stems of nettles, oats, thistles, vetches, etc. This close embrace is sinister in character, for, as may be guessed from the entire absence of leaves and green-colouring matter, the plant is a parasite. Its stem is a mere thread, varying from red to yellow in hue, and having at frequent intervals bunches of reddish flowers. These are very small, but if separated will be found to consist of a four- or five-parted calyx, a persistent pitcher-shaped corolla of similar parts, and stamens to match. Styles two, entirely within the flower. This species is not found north of Yorkshire, and is everywhere rare. It flowers from July to September. The common species, to be found growing on thyme, heather, and furze, is,-

The Lesser Dodder (C. epithymum), with finer stems of a more crimson tint, and 
the styles protruding. There is a variety of this which confines its attention to the clover plant, and has, in consequence, been raised to the dignity of a separate species by some authors ( $C$. trifolii). In addition there is the Flax-dodder ( $C$. epilinum), previously alluded to as having been introduced from the Continent with flax-seed.

Owing to the serious nature of the attacks of this foreign invader upon our flaxcrops Professor Buckman was induced years ago to experiment, with the object of elucidating its mode of growth. He found that seeds of Dodder sown strictly apart from any host-plants germinated in four days, and on the sixth a thread-like plant was seeking a foster-parent, but by the eighth, not having succeeded in its object, it died. Others were sown in company with flax-seed, and in a few days the young dodders attached themselves to the young flax-plants, made one or two tight coils round the victims, whose growth soon lifted the dodders right out of the soil, and thereupon the parasites sent aerial roots into the flax, and their natural roots dwindled and perished. Thereafter its true parasitical growth is most rapid, to the detriment of the foster plant.

The genus is included in the Natural Order Convolvulacex.

\section{Corn Cockle (Githago segetum). Plate 72.}

Wandering through or round the cornfields any time from June to September we are almost sure to find this beautiful flower. It is first cousin to the Lychnis, already described, and in general structure agrees with it, only differing from it in having a leathery calyx, and in the absence of the crown of little scales which surround the mouth of the corolla-tube in Lychnis. They produce honey, but owing to the length of the tube it is only accessible to the long tongues of butterflies and moths, who are instrumental in effecting its cross-fertilization. The plant is an annual, with erect branching stem, clothed with white hairs. The leaves are long and narrow, four or five inches long. The woolly calyx is in one, strongly ribbed, with five very long leaf-like teeth, that considerably exceed the petals in length. The flowers are purple, and measure nearly two inches across.

This is the only native species; indeed, some writers consider it to be only an introduced plant-a form of Agrostemma gracilis that has been altered by its continuous growth in our cultivated fields. 
$-71-$

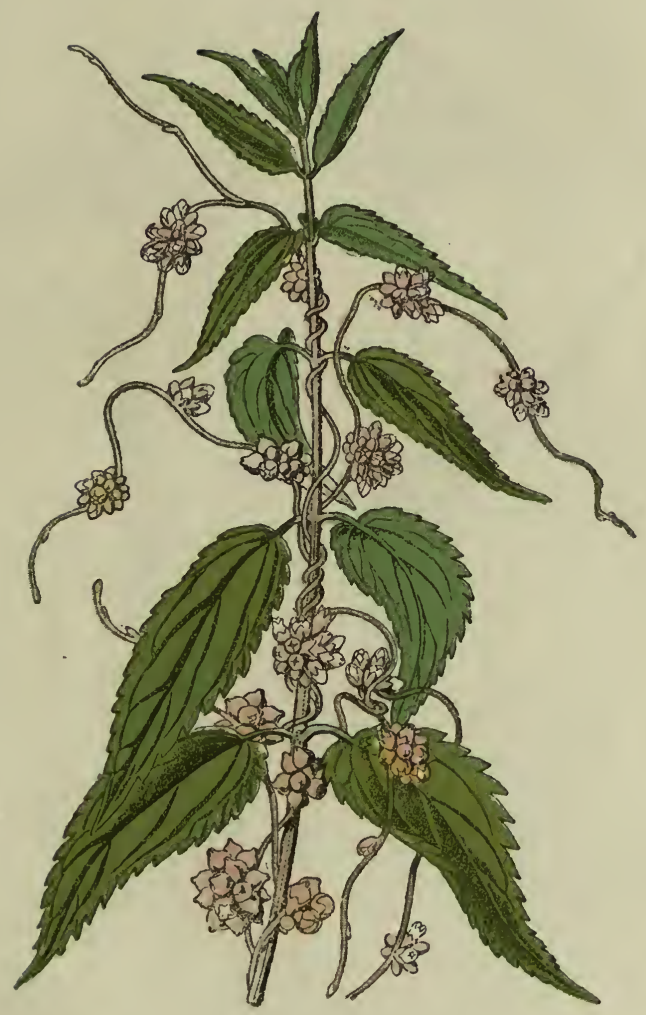

Greater Dodder.

Cuscuta europæa.

- Convolvulaceas. - 
$-72-$

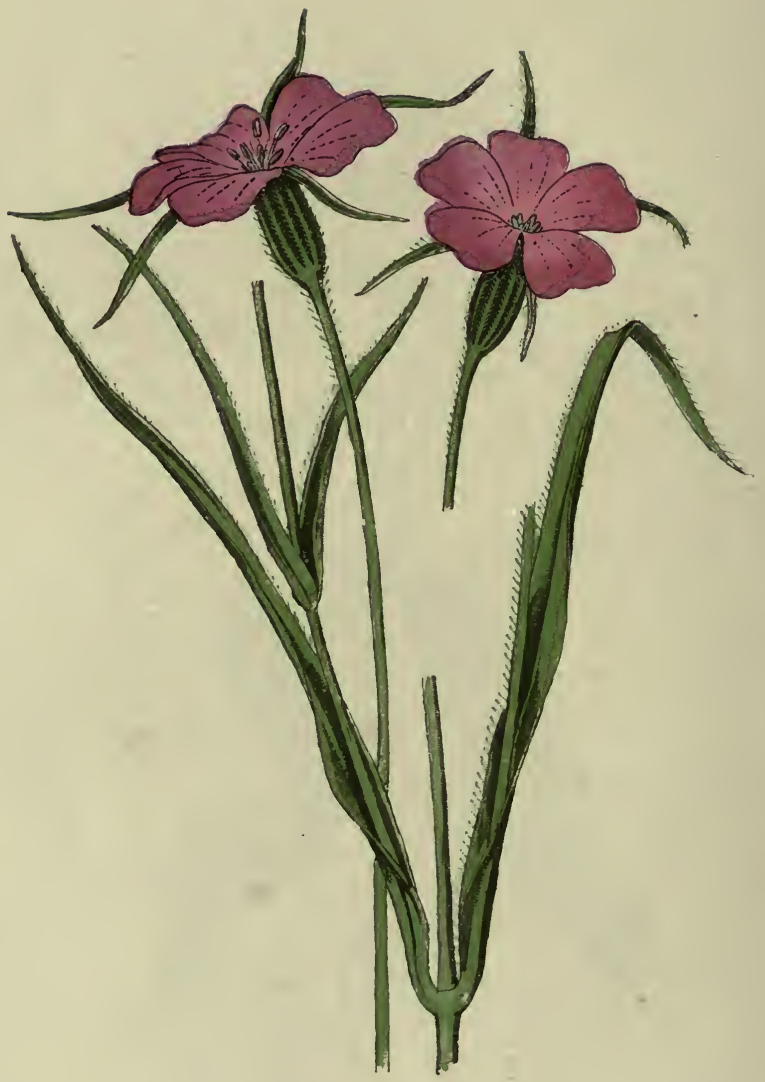

Corn Gockle.

Githago segetum. 


\section{Purple Medick or Lucerne (Medicago sativa.) Plate 73.}

Though the rambler will find this handsome plant growing apparently wild in the hedgerow and on the borders of fields, he must not too hastily conclude it is a native. The species has been largely grown here as a green fodder plant, for which it is highly esteemed, and it has escaped from the fields and reproduced itself without man's aid. A glance at its flowers will show it is a leguminous plant. Its stems are hollow, branched; its leaves trifoliate, with long-pointed stipules at the base of the leaf-stalk. From the axils of the leaves arise long.stalks, whose free ends are crowded with the deep purple (sometimes yellow) flowers. A peculiarity of this genus consists in the seed pod being more or less spirally twisted. In the present species it is downy and has two or three coils. It flowers from May to July.

It has been thought to be a cultivated variety of the next species, M. falcata. The name Medicago is from the old Greek medike, so-called because it was introduced into Greece by the Medes. The following species also occur in this country :-

I. Yellow Sickle Medick ( $M$. falcata), with yellow (sometimes violet) flowers, and a flat downy pod coiled in the shape of a sickle or a ring. Dry gravelly banks, old walls and sandy wastes in the Eastern Counties. June and July. This and $M$. sativa are perennials ; the following are annuals :-

II. Black Medick or Nonsuch (M. Inpulina). So much like Trifolium procumbens, described on p. 49, that farmers have given it the name of Hop-Trefoil, which properly belongs to the latter species, from which this may be easily separated by noting that the black kidney-shaped pods are naked, that is, not wrapped in the dried flower. It should also be observed that the pods are marked by prominent veins running throughout their length. Flowers small, crowded, yellow. Waste grounds and cultivated fields. May to August.

III. Reticulated Medick (M. denticulata). Stems creeping. Leaflets heartshaped, toothed. Flowers yellow, in umbels. Pod beautifully covered with network of veins; broad, flat, and coiled into a spiral; edges with double row of spines. South and Eastern Counties, and Ireland. May to August.

IV. Spotted Medick (M. maculata). .Similar to last, but pod more globose, network faint, the spines long and curved. Leaflets often with black spot in centre. Leaf-stalk hairy. Gravelly pastures and hedgebanks in England and South Ireland. May to August. 


\section{Yellow Iris or Flag (Iris pseudacorus). Plate 74.}

Fringing our rivers, ditches and lakes, the Yellow Iris appears to be defending them with drawn sword. Everybody knows the sharp-edged leaves of this species, that may cut the hands of the gatherer if he be not careful. Equally wellknown are the bright blossoms that begin to appear in May and keep up a succession until late in July; but probably most of the unscientific readers who have honoured me with their company thus far-and who have learned, I trust, to know the parts of a flower at sight-would be incorrect in their description of this common flower. Anyway, it will be worth their while dissecting a flower. The parts of the flower are in threes, but the sepals are more petal-like than the petals, and so are the styles. The sepals are in fact the most striking organs ; they are broad, and reflexed to form convenient alighting platforms for a heavy humble-bee. The petals are narrow, erect, or curved towards the centre of the flower, to be out of the way of the broader, arching style, which is spread out and coloured like a petal, with the stigmatic surface near the upturned tips. Beneath this arching style lies the anther, similarly curved, and opening away from the stigma.

Note the why and wherefore of this departure from orthodox arrangements of floral organs. At the bottom of the flowertube honey is secreted, and to obtain this the flower is visited by humble-bees. In order that his long tongue may reach the honey, the bee has to push his head and back against the stigma and the anther. If he has previously visited a flagflower his back will be covered with pollen, some of which will adhere to the stigma. He will also take away on his head and back some of the pollen from the flower he is now visiting, and will fertilize other flags with it.

There is another British species,-

The Stinking Iris, Gladdon, or Roast-beef plant (Iris 


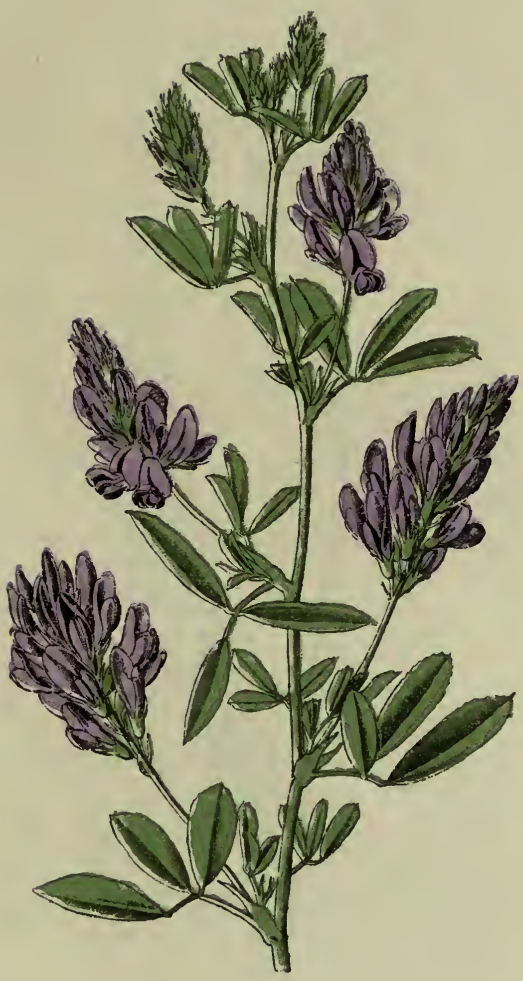

Lucerne, Purple Medick.

Medicago sativa.

- Leguminos和. - 
$-74-$

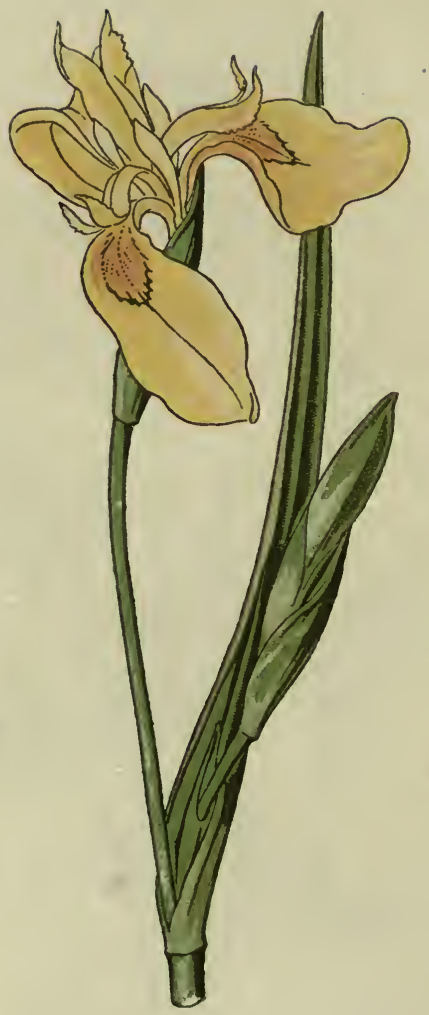

Yellow Iris. Flag.

Iris pseudacorus.

- IRIDEE. - 
fotidissima), with purple sepals, yellow petals and stigmas. Flowers not quite so large as the last. Woods and copses. May to July.

\section{Marsh Orchis (Orchis latifolia).}

There are nearly forty British species of Orchideæ, divided into sixteen genera; and in the space at our disposal it is impossible to give anything like an adequate account of the group or of the specific characters. An attempt will be made, however, to make the reader acquainted with the general structure by means of three figures. The first of these represents the Marsh Orchis (O. latifolia), a species commonly to be met in wet meadows and marshy places, flowering from May to July. The two tubers are palmate, that is, more or less flattened like a hand, and terminating in finger-like processes. The leaves chiefly spring from the summit of one of these tubers, the lowest acting as sheath for the next, and so on, the tubular flower-stem rising through all the sheaths. The leaves are oblong, and spotted with purple. The inflorescence is a spike, the flowers crowded upon it, but separated by the long three-nerved green bracts. The structure of these flowers will be found to differ widely from all we have considered in these pages. The perianth is placed above the (consequently inferior) ovary, which is twisted. This twist, it will be well to bear in mind, brings the flower "upside down." The three sepals and the three petals are equally coloured, and it is therefore convenient to speak of them as the perianth. There is only one stamen, which is supported by the pistil. Two of the perianth leaves combine to form a hood over the stamen, and a third is greatly larger than the others, divided into three lobes and hanging down like the lip of a labiate flower. This is known as the labellum, and it is continued backwards and downwards as a hollow spur, in which, however, honey is not 
secreted. At the top of this spur, at the back, is the stigmatic surface, and above it protrudes a fleshy knob, called the rostellum, which supports the anther. This organ consists of two lobes, side by side, which open in front, and reveal in each a mass of pollen grains tied together by elastic threads and attached to a slender foot-stalk with a sticky base. This is a tedious description, though we have made it as brief as possible. The reader shall see the reason for it if he will conduct a little experiment. We may premise that these orchids are fertilized by long-tongued insects, who suck the juice through the tender skin lining the spur.

Now for the experiment. Take a finely-pointed pencil, which we will pretend is the head and tongue of a humble-bee in search of this sweet juice. We push the point gently down the spur, when a part of the pencil touches against the rostellum and presses it down, touches lightly the viscid feet of the pollen masses (pollinia), and as the pencil is withdrawn both come with it, and stick out from it like a pair of horns. Be careful to hold the pencil in the exact position it now occupies, and watch. The heavy heads of the pollinia are drooping forward, but after a few minutes they cease to fall lower. Now push the pencil into this other flower. The pollen-masses go directly to the stigma, and some of the pollen is detached. If you are watching where orchids grow it is no uncommon thing to see insects flying around with these pollinia attached to their heads or tongues like a pair of horns.

It will be seen to be impossible for the pollen to fall upon the stigma of the same flower, and from its elastic attachments it is impossible that it should be carried by the wind to another flower, so that insect agency is here an absolute necessity. 


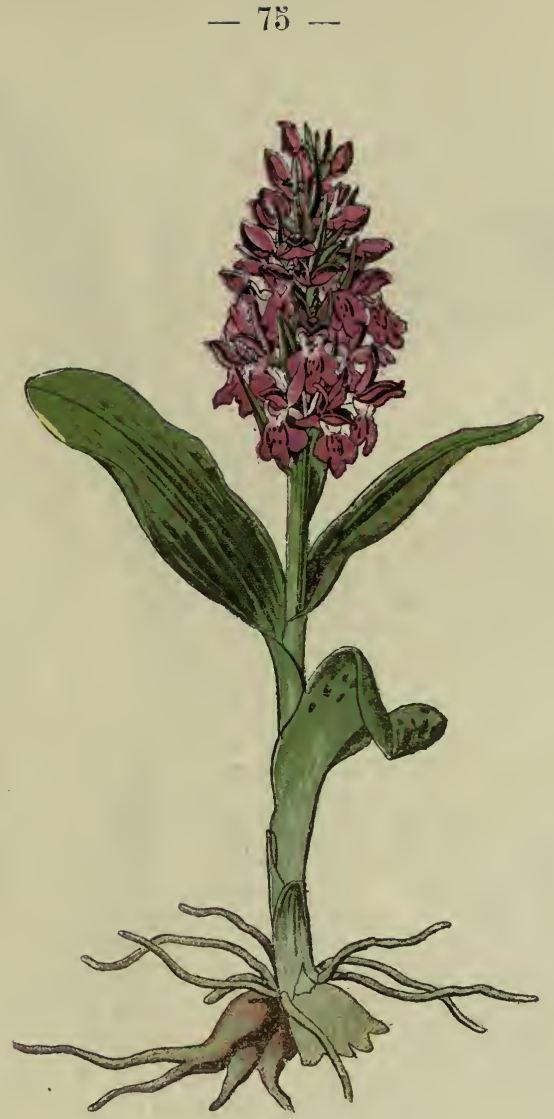

Marsh Orchis.

Orchis latifolia.

- ORGHIDACE E. 
$-76-$

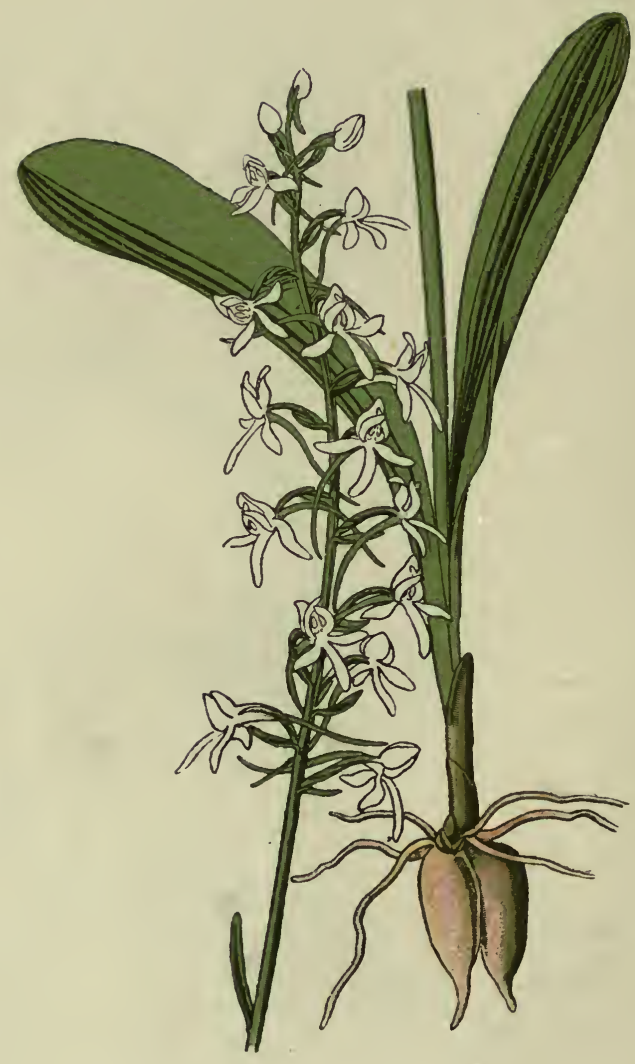

Butterfly Orchis.

Habenaria bifolia.

- ORChide天. - 


\section{The Butterfly Orchis (Habenaria bifolia).}

This species is very similar in structure and habit to the Marsh Orchis, but the tubers are more cylindrical in shape, the radical leaves almost always restricted to two, the flower-spike lax. Flowers white with a greenish tinge, the labellum and spur very long: fragrant. The stigma two-lobed. Fertilized by moths. Occurs in meadows, hill-sides and woods, flowering from June to August.

\section{The Bee Orchis (Ophrys apifera).}

In the genus Ophrys we have three species whose flowers bear quite startling likeness to a bee, spider and fly respectively. What is the purpose of this counterfeit presentment it is difficult to conjecture. It has been suggested that it might be to warn off or deceive insects, as the flowers are selffertilized, but Charles Darwin did not think this was the probable reason. There is no spur in this group, there is no rostellum, and the ovary is not twisted. The stalks (caudicles) of the pollinia are so long and thin that the weight of the pollen masses causes them to bend over and touch against the stigma, fertilizing it.

I. Bee Orchis (O. apifera). The labellum is very convex and broad, three-lobed, of a rich velvety-brown colour, with a tail. The sepals are pinkish. The spike has only about about half a dozen flowers upon it, with a large leafy bract under each. Hillsides, fields and copses on chalk and limestone, chiefly in the South of England and Ireland. June and July. (Plate 77.)

II. Spider Orchis $(O$. aranifera). Similar to the last, but the sepals greenish, labellum differently marked, and without a tail. Similar situations to apifera, but much more rare. April and May.

III. Fly Orchis $(O$. muscifera $)$. Sepals greenish, labellum narrow, flat, brown, with a yellow-edged, squarish blue patch. Strikingly like a fly. May to July.

The name of the genus is from the Greek, ophrus, an eyebrow, said to refer to the markings on the labellum.

Several other British species in different genera from those named bear similarly strange likenesses, such as the extremely rare Lizard Orchis (Orchis hircina), but some of the foreign forms are more remarkable still. 
In addition to the species figured and those briefly described, we would call attention to a few others that may come under the rambler's notice. In boggy ground and sphagnum beds he may be so fortunate as to find the rare Bog Orchis (Malaxis paludosa), a small plant with tiny yellow-green flowers (July to September), and the scanty leaves producing bulbils from their edges which grow into new plants. In similar situations in the eastern counties he may even find the larger but much rarer Fen Orchis (Liparis loeselii).

A singular species, to be found chiefly in beechwoods throughout the country, is the Birds'-nest Orchis (Neottia nidus-avis), so called from the peculiar character of its roots, which are stout and juicy, and woven into a resemblance to a nest. The whole plant is of a pretty uniform brown tint-both stem and flowers. There are no leaves, for the plant lives upon decaying vegetable matter, and has no necessity to bother about chlorophyll. It is botanically known as a saprophyte. Flowers June and July.

The very distinct Twayblade (Listera ovata) is sure to be encountered in woods and pastures. Its two leaves are very broad, and appear to be opposite, but are not really so. The flowers are small and greenish ; they appear in May. There is a singular fact in connection with the fertilization of this plant that should be noted. The pollen-masses are dry and friable, and would not be likely to adhere to insects. But if the rostellum be touched ever so lightly, it instantly exudes a gummy fluid, which enables the pollen to stick tightly to the insect causing the irritation. Examine the flower with your lens, irritate the rostellum by prodding it with the point of a hair from your own head, and note what you observe.

At the end of Summer in dry pastures there may be found a slender plant with a twisted spike of fragrant white flowers. These flowers are very small, enclosed each in a hood-like bract. It is the Autumnal Lady's-tresses (Spiranthes autum- 


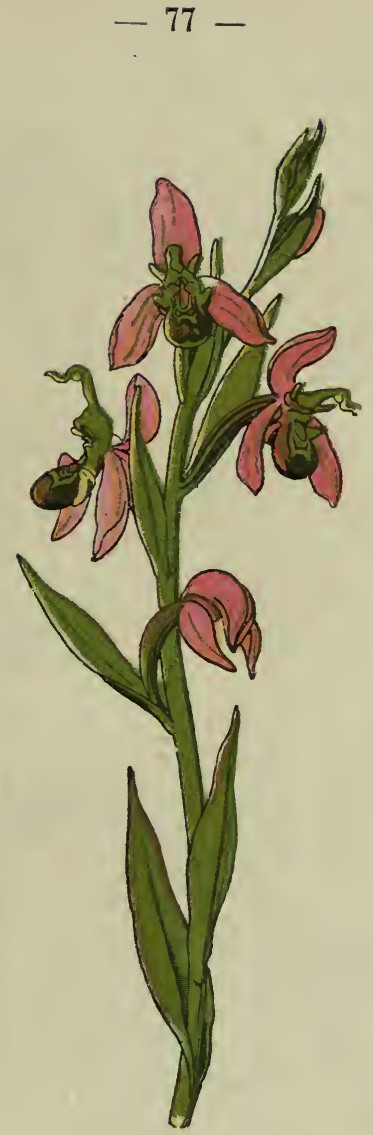

Bee Orchis.

Ophrys apifera.

- ORGHIDEA. - 


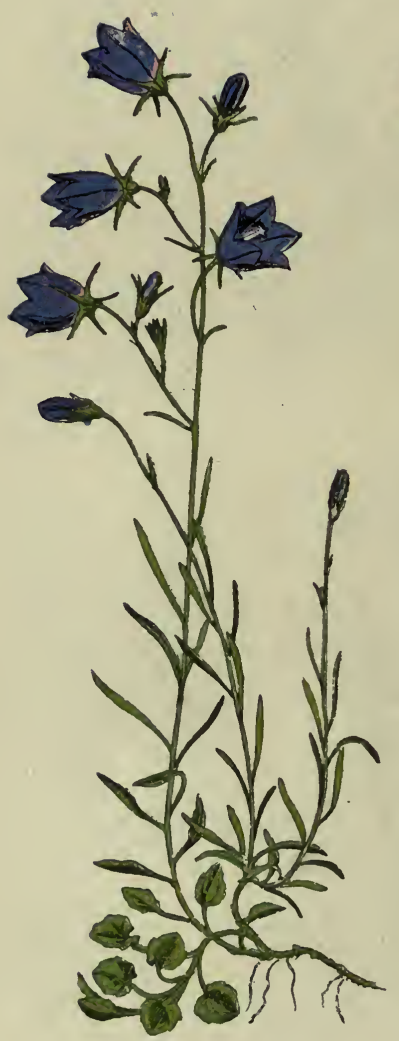

Harebell.

Campanula rotundifolia.

- Campanula Ge玉. -

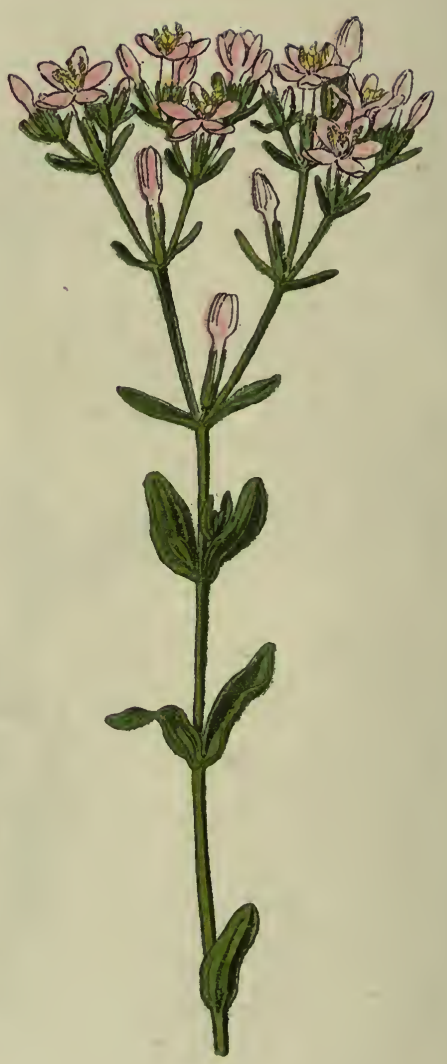

Gommon Centaury. Erythræa centaurium. - Gentianeж. - 
nalis). The rosette of leaves from the root does not appear until after the flowers.

\section{Hairbell or Blue-bell (Campanula rotundifolia).}

This is the true Blue-bell of Scotland. As we have indicated (page I4), the Blue-bell of the Southron is the Wild Hyacinth. Scotsmen are very sensitive upon the point of the Hyacinth having so dear a name bestowed upon it, when it has already a sufficiently good and classical one, and there are few, if any, more certain ways of rousing a Scot than by exhibiting Scilla as the true Blue-bell, or by describing Campanula as the Hairbell. Others have found the plant a fruitful source of controversy on a philological point-should it be spelled Hairbell or Harebell?-does its name refer to the slender hair-like stems, or to its habit of growing where hares delight to revel? As against Hairbell, which is descriptive of the plant, Harebell has no chance of retention among botanists, whatever philologists may say.

There are six species of Campanula included in the British flora, of which two are rare, and one of these is probably only an escape from cultivation. The characteristic of them all is a beautiful bell-shaped corolla with five lobes, five stamens, and the style with three to five stigmas. They are mostly perennial, and the flowers most frequently blue. C. rotundifolia has a creeping rootstock, and several slender-angled stems. The first formed leaves, near the ground, are more or less rotund in shape, and stalked, but as they occur higher up the stem they are more and more linear. The flowers are nodding or drooping, and swayed by the breeze. Heaths and pastures. July to September.

The Nettle-leaved Bell-flower (C. trachelium) is an erect tallstemmed (3 feet or more) hairy species, with leaves like nettles, with large purple flowers in a terminal panicle. Woody lanes and copses. August to October. 


\section{The Centaury (Erythrcea centaurium).}

A very neat and beautiful plant, not nearly so well-known as it should be. It is an annual plant, with erect stem, less than a foot in height, the leaves in pairs growing together at their bases, and funnel-shaped pink flowers produced in terminal cymes. It grows in woods and sandy or chalky pastures, flowering from June till September.

The name is from the Greek, Eruthros, red, in allusion to the pink flowers.

\section{Wild Mignonette (Reseda lutea), and Weld or Dyer's-weed (Reseda luteola).}

So familiar is the Sweet Mignonette of our gardens, and so like and yet unlike are these wild species, that whilst no one would take them for the garden plant one need not be a botanist to see their natural affinities at a glance. Like their garden relative these are annual herbs, becoming biennial when we have mild winters; with flowers that are individually inconspicuous, but which gain sufficient prominence by being associated in racemes. In colour they are a yellow-green. The calyx is irregular, and divided into from four to seven narrow segments ; there is a similar number of unequal petals, each deeply cleft into two lobes, and a multitude of stamens. The stigmas are lobes at the mouth of the open ovary.

I. Wild Mignonette ( $R$. lutea) grows in dry waste places, especially in chalky districts. Its leaves vary a great deal, but are either pinnate or deeply lobed in a somewhat irregular manner. Flowers, pale-yellow in a tolerably dense raceme. Very similar to the Sweet Mignonette, but stiffer, more erect, and scentless. Flowers June to September.

II. W'eld (R. luteola). This is a much taller plant than R. lutea, with longer racemes and denser; the flowers more green than 


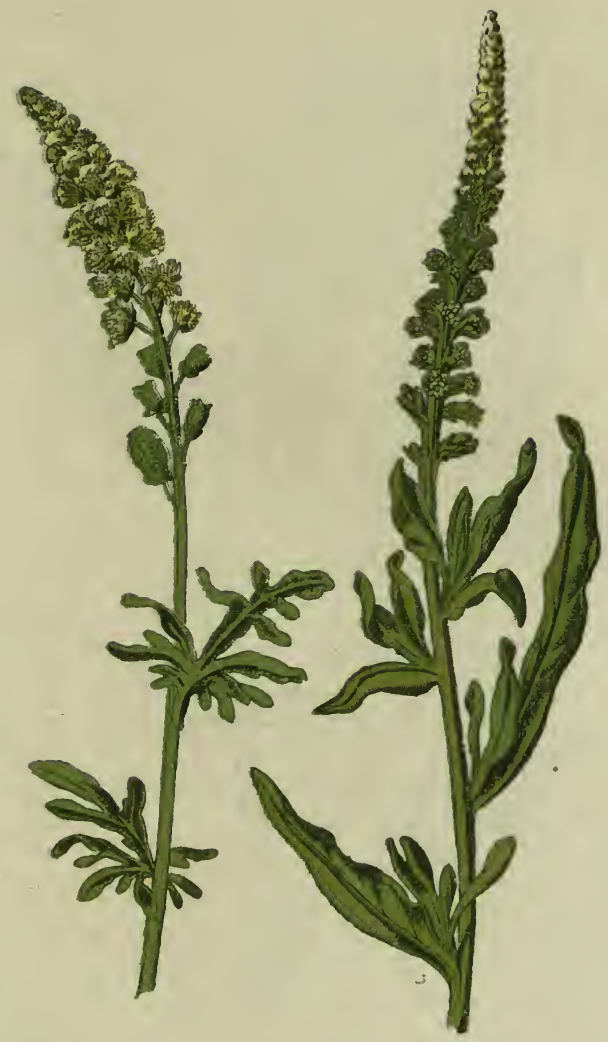

Wild Mignonette. Reseda lutea. Weld. Dyer's Weed. Reseda luteola. 
$-80-$

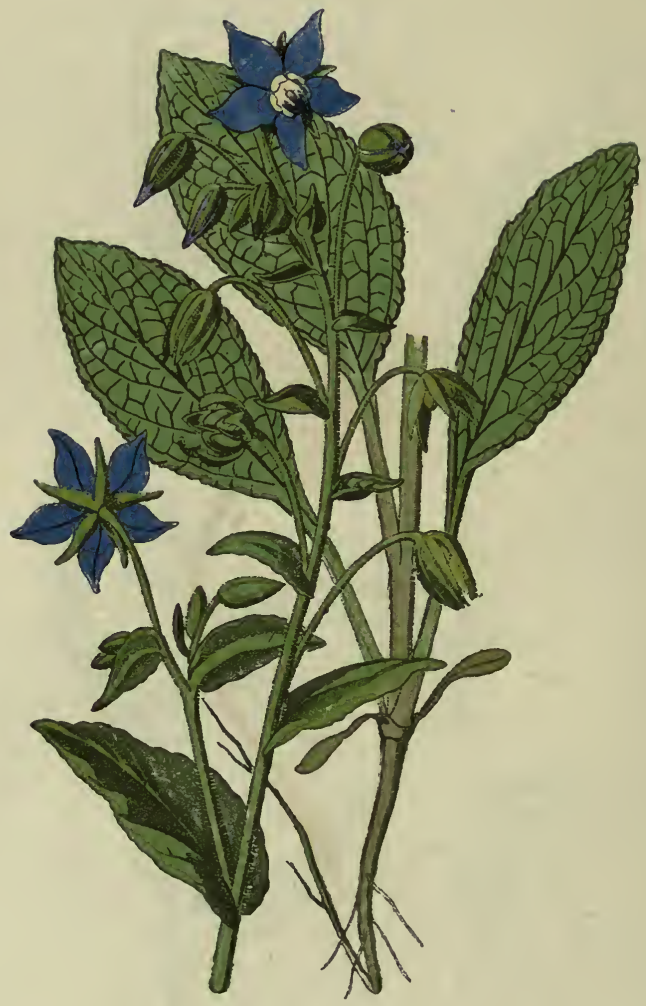

Borage.

Borago officinalis.

- Boraginez. - 
yellow, and with undivided glossy leaves. Petals, three, four, or five. In the days before aniline colours this plant was much used by dyers, and cultivated for their purposes. It yields a beautiful yellow dye, and its juice is also used in the preparation of the artist's colour called Dutch pink. It is a common wayside plant in England and in Ireland, more rare in Scotland, and flowers from June to September.

The name is from the Latin, Resedo, to appease, from these plants being formerly considered as sedatives.

\section{Borage (Borago officinalis).}

This is a plant one may find on rubbish heaps and waste ground anywhere near the habitations of man, for it is not, strictly speaking, a native, though thoroughly well-established here. An old adage runs : "I, Borage, always bring courage," and it was supposed to brace up the heart for great enterprises. It was therefore widely cultivated in old gardens, and has survived to this day in the grounds of old houses, where it has frequently made its escape, or surplus plants have been thrown out upon the rubbish heaps. Instead of allowing itself to go the way of garden refuse, it has taken hold of the ground there, multiplied and brightened the place with its beauty.

Every part of the plant, except the corolla, bristles with short stiff hairs. It has an erect juicy stem, and rough, lanceshaped leaves, the radical ones on long footstalks, those on the stem stalkless and clasping their support. The sepals are five in number, long and narrow, cohering by their bases. The corolla is of the form technically known as rotate, that is, with the petals joined at their lower parts to a short tube, from the top of which five pointed lobes radiate. It is coloured a most brilliant and beautiful blue, such as is rarely seen in flowers. There is a pale yellow ovary that secretes honey, and around it, attached to the throat of the corolla-tube, are the five united 
stamens. The anthers are dark purple, and open in such manner that the pollen falls between them and the pistil, somewhat as in Viola. By this arrangement both honey and pollen are protected from the depredations of insects who have no right to it. Bees, however, in forcing their tongues down to the honeyed ovary, separate the anthers and let loose the pollen, which falls upon their heads and will be brought into contact with the stigma of another flower at their next visit. Cross-fertilization is further helped by the stigmas of a flower not becoming ripe until its anthers have shed their pollen. Flowers June and July.

Name probably from the Latin Bourra, a flock of wool, in allusion to its hairy character.

\section{Oblong Pond-weed (Potamogeton polygonifolius).}

We have pond-weeds in abundance, but the Potamogetons are the pond-weeds par excellence. There is scarcely a piece of water in this country, be it river, lake, pond, canal, or intermittently dry ditch, but has one or more species growing there. The genus is a very difficult one, such as it is impossible to do more than show the general characters of here. Hooker and Bennett, in their revision of the genus, give twenty-one British species with a number of connecting sub-species and varieties. The one figured here is the Oblong Pond-weed ( $P$. polygonifolius), with narrowly egg-shaped floating leaves, and narrower submerged leaves. All have long leaf-stalks. The floating leaves always present the upper side to the air, and are always perfectly dry. The flowers are greenish and unattractive, collected into a slender spike. Individually they consist of a four-parted perianth, four stamens, four carpels. There is a species ( $P$. natans) with broader floating leaves and narrow submerged leaves. A broader still is $P$. plantagineus, with clearer leaves and more slender leaf-stalks. $P$. crispus, $P$. densus, $P$. perfoliatus, $P$. 
$-81-$

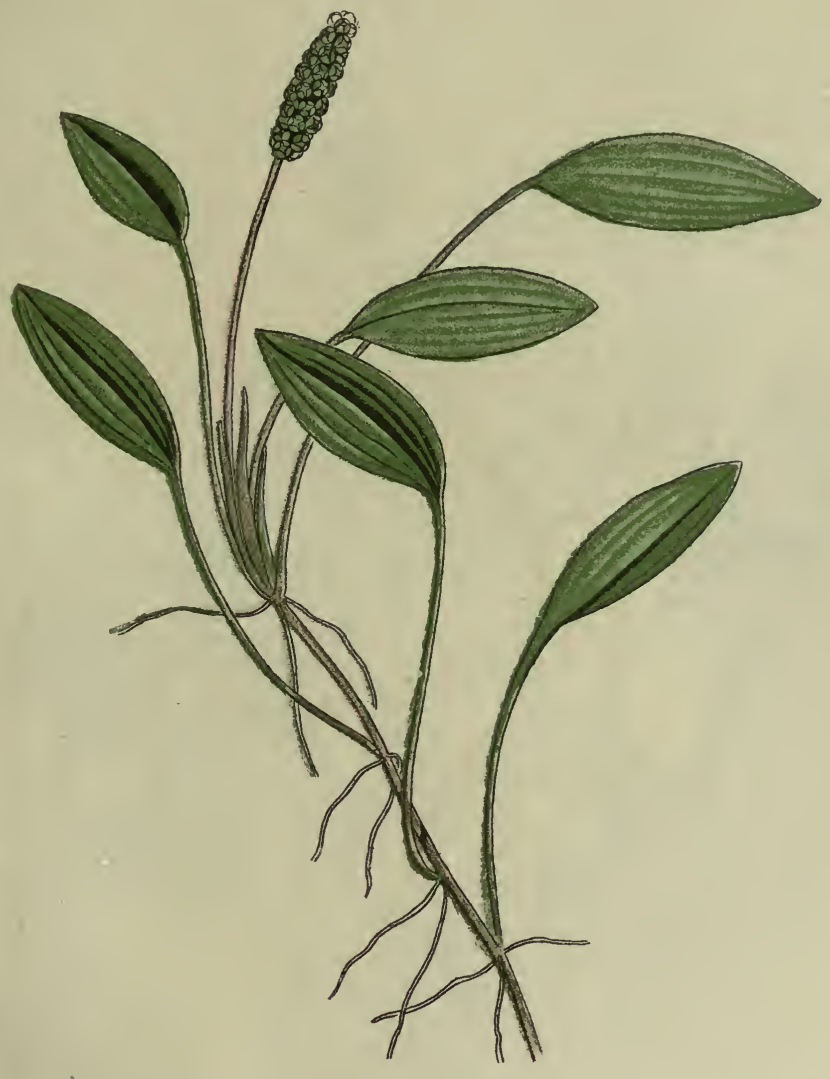

Oblong-leaved Pond-weed.

Potamogeton polygonifolius.

- NAIAdEA. - 


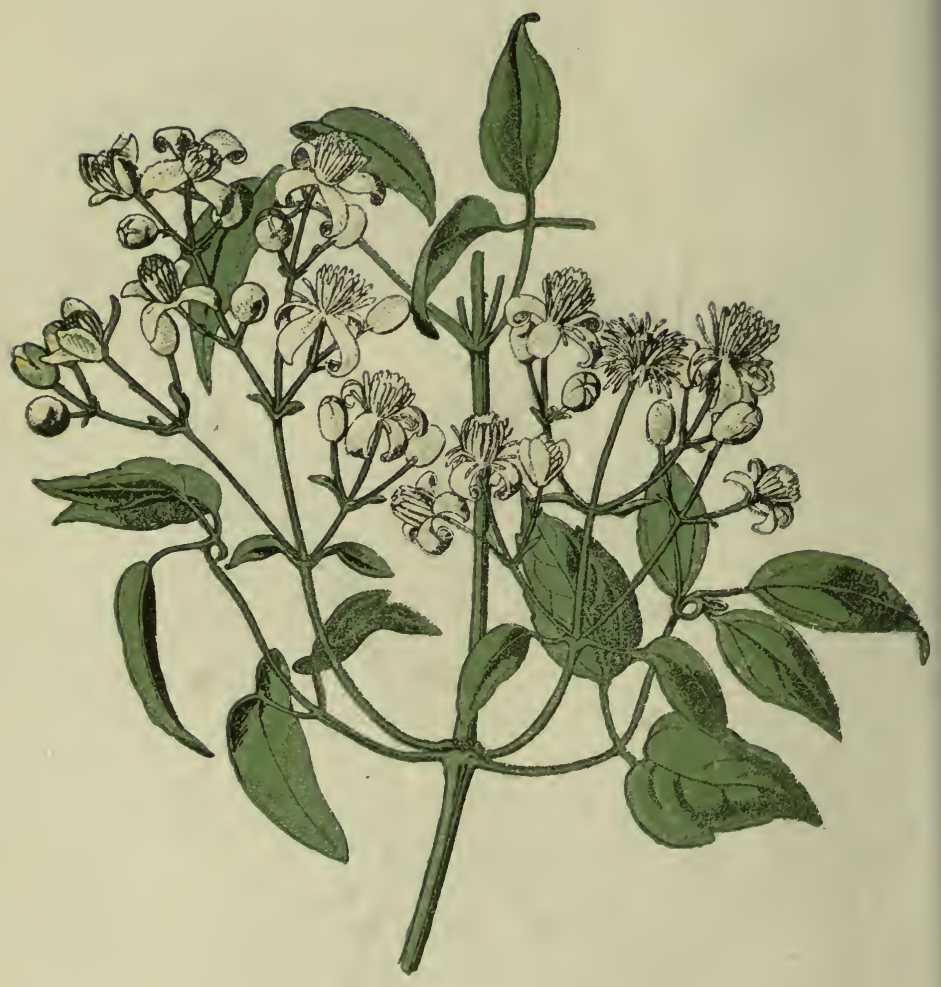

Traveller's Joy.

Clematis vitalba.

- Ranunculaceas. - 
pralongus, etc., have only submerged leaves, which are more or less oblong.

The species with floating leaves form refuges for many interesting low forms of life, and the microscopist will find them very fruitful in specimens for him.

The name is from the Greek words, potamos, a river, and geiton, a neighbour.

\section{Trareller's Joy (Clematis vitalba).}

When rambling, in chalky districts especially, our readers will meet this climbing shrub at every turn, scrambling over all the hedges, flinging its arms out over the way, and clinging persistently to any branch or shoot it touches. It has a variety of names, some of which may be applied at different seasons by persons who think they are speaking of different plants. In the early summer it may be the White Vine, or the Virgin's Bower ; in autumn, when the feathery awns are lengthening on its seed-vessels, it may fitly be called the Old Man's Beard, and when winter has cleared most things away from the hedges, but left these gleaming feathers in abundance, it may give the Traveller Joy to see them as he passes.

It is a perennial plant, with a tough stem, climbing by means of its leaf-stalks, which curl round any likely support, and become hard as wire. The leaves are opposite and compound, the leaflets usually five, the stalks of these also acting as tendrils. The flower has no corolla, but the four thick sepals are coloured geenish-white to serve instead. The stamens are a crowd round the central cluster of many-bearded styles, which afterwards elongate and become the "old men's beards." The flowers, which are slightly fragrant, may be found from July to September.

The Traveller's Joy is peculiarly English, so far as its distribution in the United Kingdom is concerned. It is found only to the south of Denbigh and Stafford. This, too, is the 
only British member of the genus; but a very large number of foreign species are cultivated in our gardens, where they are quite hardy.

The name is from the Greek Klema, a vine-twig.

\section{The Self-Heal (Brunella vulgaris).}

A perennial herb of the wayside and the damp pasture, that has fallen upon evil days, so far as reputation is concerned. Time was when it was considered one of the most useful medicines for inward and outward wounds. Culpepper says " he needeth neither physician nor surgeon that hath Self-heal and Sanicle to help himself," and he prints that sentence in italics, to impress it more firmly upon his readers. On this account it was called Carpenter's Herb, Hook-heal, Sickle-wort, and Prunella. The last is a softened form of Brunella, from the German Bräune (quinsy), because it was believed to cure that complaint. Its reputation has passed, but the names remain, and one has been adopted as its scientific appellation.

There is a suggestion of the Bugle in its general appearance, but seen together (see page $2 \mathrm{I}$ ) there is no danger of mistaking them. In Ajuga the whorls are far apart, in Brunella they are contracted into a dense head. The corolla here is broader, the upper lip erect and vaulted, whilst in Ajuga it is short and notched.

The plant has the square stem, lipped flowers, and four stamens, characteristic of the Labiate order, a creeping rootstock, and stalked leaves; these are long, oval, toothed, or with entire margins. The bracts of the flower-spike have purple edges. Leaves and stem more or less hairy; flowers purple, sometimes white or crimson. July to September. Occasionally small flowers are produced later, in which the anthers are suppressed, but the pistil is perfect.

This is the only British member of the genus, whose name has been explained above. 


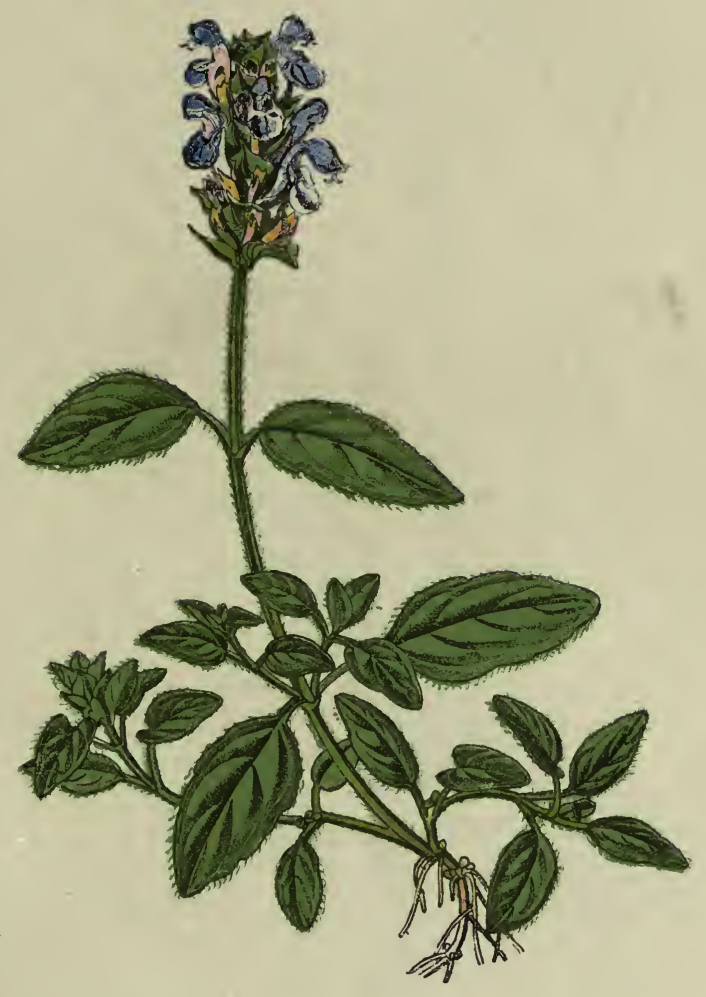

Self-heal.

Brunella vulgaris.

- Labiatæ. - 
$-84-$

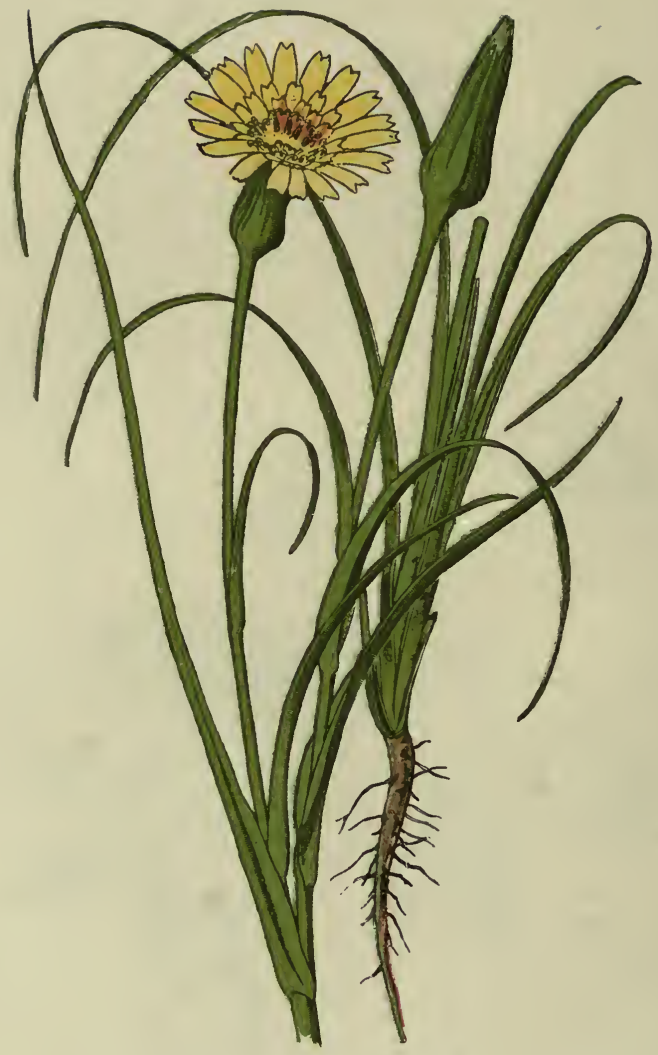

Goat's Beard.

Tragopogon pratensis.

- CoMposite. - 


\section{Goat's Beard (Tragopogon pratensis).}

One of the folk-names of this plant is "John-go-to-bed-atNoon," and I think it is the only example of a British plant name that is a sentence of six words. "Three-faces-under-ahood" runs it pretty closely, but the few names we have of this order do not usually exceed four words ; such as Queen-of-theMeadows, Jack-by-the-hedge, and Poor-man's-weatherglass. John-go-to-bed, etc., is a nice expressive name, and is due to the fact that the flower is an early-closer with a vengeance. It is probably the originator of the eight-hours day, for it opens at four in the morning and closes by twelve. Farmers' boys were said of old to consult its flowers with reference to dinnertime, but probably in these days of machine-made watches the practice is obsolete.

Goat's-beard has a tap-root, somewhat like a parsnip, and long curling grass-like, stalkless leaves that clasp the stem by their bases. The flower-heads are solitary, yellow, and the eight involucral bracts are united at the base. All the florets (like those of Dandelion, Sowthistle and Chicory) are rayed, and contain both stamens and pistil. They are invested with pappus hairs (see page 20), which are stiff and feathered. It is from these beards the plant gets its English name, which is reproduced in the Greek words from which the name of the genus is composed, tragos, a goat, and fogon, a beard. It flowers during June and July, and is fairly conmon in meadows and wastes in England; much more rarely in Scotland and Ireland.

There is an introduced species with larger purple or rose-coloured flowers, found occasionally in damp meadows. This is the Salsify (Tragopogon porrifolizs). It is occasionally grown for the sake of its roots, which have a medicinal value, but inferior to those of Scorzonera, which it somewhat resembles. 


\section{Wild Thyme (Thymus serpyllum).}

The Wild Thyme grows on the hills and the high heath lands, usually among fine grasses that are close-cropped by sheep and rabbits; or if on lower ground it will probably be found upon the light and well-drained soil of a mole-hill among mosses. In spite of its diminutive stature it is a shrub, with a woody rootstock and a creeping stem, from which arise the flowering stems. The leaves, which are very small and stalked, are egg-shaped, with even margins, often turned under. The rosy-purple flowers are prorluced in spikes. They are of the usual labiate type, and both the calyx and the corolla are two-lipped. The upper lip of the calyx is three-toothed, the lower cleft in two, the whole of a purplish hue. The upper lip of the corolla is straight and notched, the lower cut into three lobes. There are two forms of flower-smaller and larger ; the small are perfect, the larger bearing developed anthers only. It should be noted also that in the complete flowers the anthers shed their pollen before the stigmas are ripe ; selffertilization is therefore impossible. The flower produces much honey, the whole plant is highly fragrant, and in consequence is very much visited by insects who carry the pollen. While the stamens are ripe the pistil is short and almost hidden within the corolla-tube; when the pollen has been shed the style elongates, the two arms of the stigma diverge and occupy a prominent position far outside the lips. Under this arrangement insects alighting on the younger flowers dust themselves with pollen, and upon visiting those a day or two older could scarcely fail to deposit some of it upon the ripe stigmas.

This is the only native species of a genus named from the ancient Greek name for the plant. 


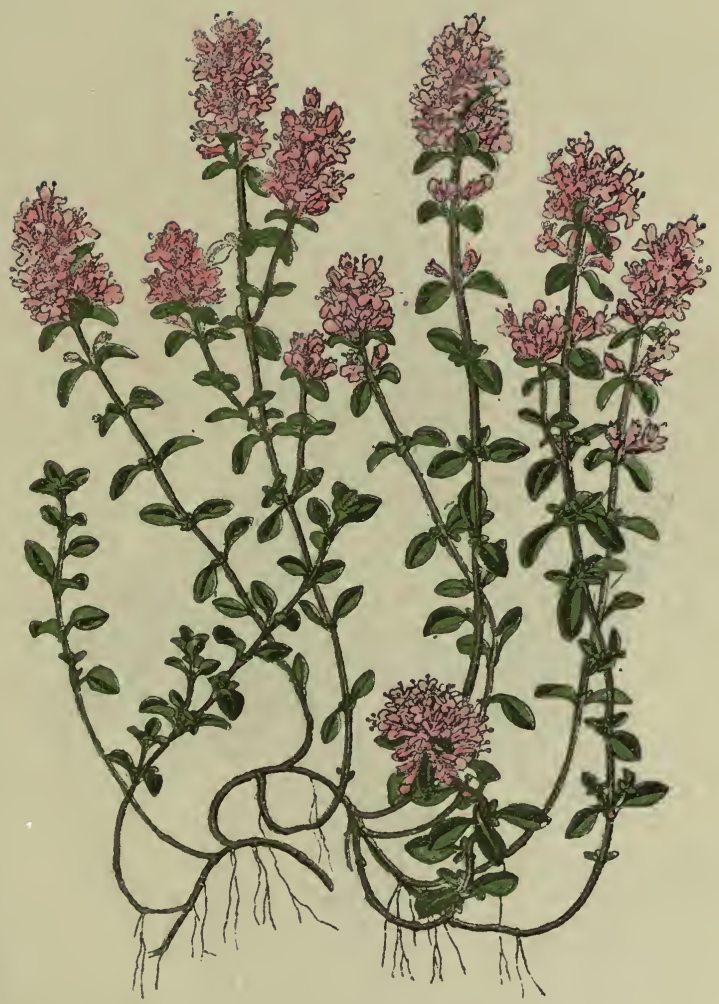

Wild Thyme.

Thymus serpyllum. 
$-86-$

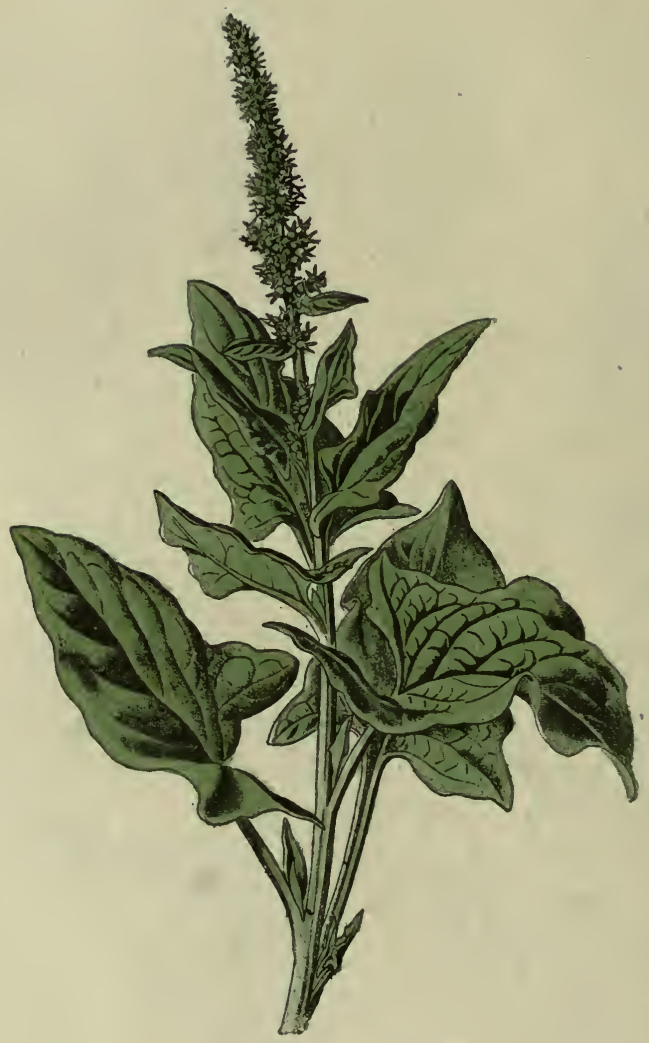

All-Good. Goose-foot.

Chenopodium bonus-henricus.

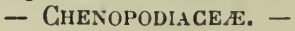




\section{Mercury Goosefoot (Chenopodium bonus-henricus).}

The genus to which this plant belongs consists of thorough weeds. Their habitat is waste places, usually where the soil is made up of man's refuse. The plants are fairly uniform in colour, from stem to leaf and flower. They are fertilized by the wind, so they have no need to put on showy colours to attract insects. The flowers are small, and the petals are entirely wanting; they consist of from three to five sepals, from two to five stamens ranged around the ovary, which is surmounted by the two or three spreading stigmas. Some are distinguished by unpleasant odours, and they have little to attract popular attention, although some have been used as potherbs-notably the species figured, and which rejoices in the alternative titles of "Good King Henry" and "All-good."

Mercury Goosefoot (C. bonus-henricus) is a perennial with a thick fleshy rootstock, and erect channelled stems from one to three feet in height. The leaves are large, dark green, and of the shape that botanists describe as "hastate," that is, like the head of an ancient halberd. These leaves are somewhat succulent, and in some places are used as a substitute for spinach. The ovary when ripe becomes what is technically known as a utricle, a thin loose case containing a single seed. In this species the seed is black, marked with small punctures. Flowers May to August.

All the other British species are annuals, and among them may be noted the Stinking Goosefoot (C. vulvaria), with spreading stems, small, greasy, mealy leaves, grey-green, and with an odour like rotten fish. Many-seeded Goosefoot (C. polyspermum), with several spreading branches, ovate leaves and many minute, rough, dark-brown seeds. White Goosefoot $(C$. album), leaves ovate, covered with a white mealy substance, upper portions toothed, sepals keeled, seed dark, shining, very minutely dotted. Red Goosefoot $(C$. nubrum), with erect, frequently red, stems, smooth and shining, leaves variable in form, and the character of the margin, sometimes toothed, sometimes entire, sepals not keeled. The name is from two Greek words, signifying Goosefoot, in reference to the shape of the leaves in some species. 


\section{Burdock (Arctium lappa).}

The Burdock is a plant well-known to artists and boys; the former being interested in it as a fine foreground plant, the latter on account of its hooked bracts, which make the fruithead an admirable instrument of torture, or an ornament for decorating some other person's clothes. In its young state the plant is suggestive of the Butterbur, the fine bold lower leaves having a densely cottony underside as in that plant. But there the similarity ends, for in Butterbur there is no rising stem, whereas in Burdock this ordinarily reaches a stature of three or four feet. We encountered a fine specimen near Chessington, Surrey, in June, I 894, that had reached the height of seven feet three inches, and as it had only just commenced flowering it would probably put on a few additional inches before its growth ceased. The stem is stout, the leaves alternate, heart-shaped, thick. The flowers are in dense heads, like a thistle, but without any spreading rays. The involucre globose, of many leathery bracts ending in long stiff hooks, by means of which the ripe heads become firmly attached to the coats of animals, and the seeds are thus carried far and wide. Corollas, five-lobed, purple. Common in all waste places. Flowering from June to September. According to Hooker this is the only British species, but the "splitters" have made four or more species out of it.

The name is from the Greek, Arktos, a bear, from its rough appearance.

\section{Goosegrass or Cleavers (Galium aparine).}

Although Goosegrass has nothing else in common with Burdock it resembles it in the fact that its fruit "sticketh closer than a brother." It is a plant of the hedge, where it forms dense masses, the whole plant-stem, leaves and fruits 

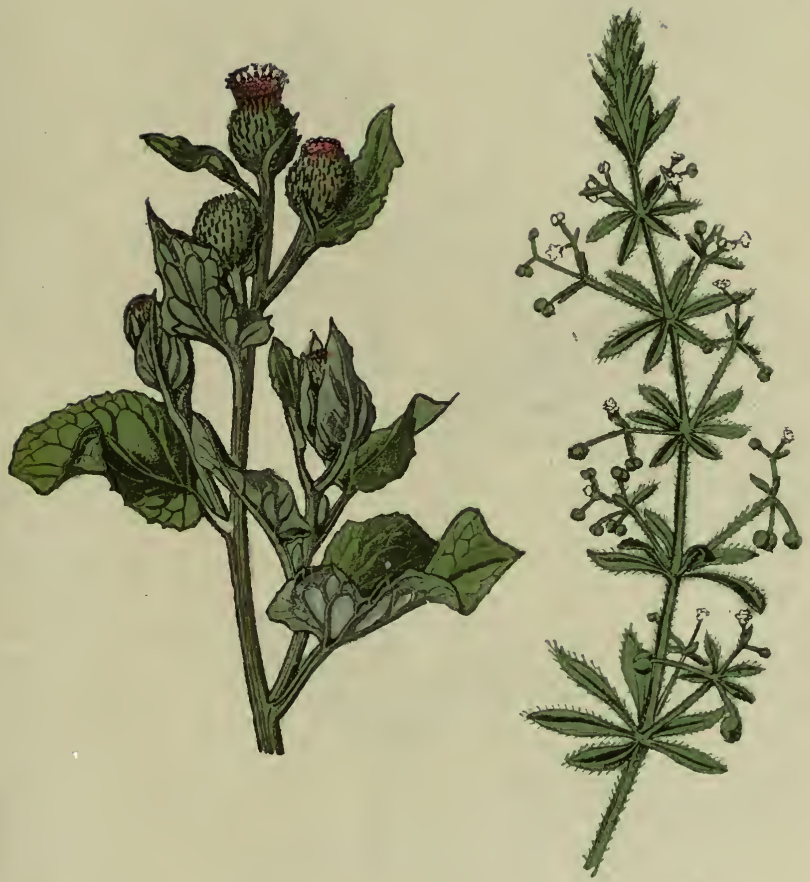

Burdock.

Arctium lappa.

- Composite. -
Goose-grass. Gleavers. Galium aparine. - Rubiace.e. - 


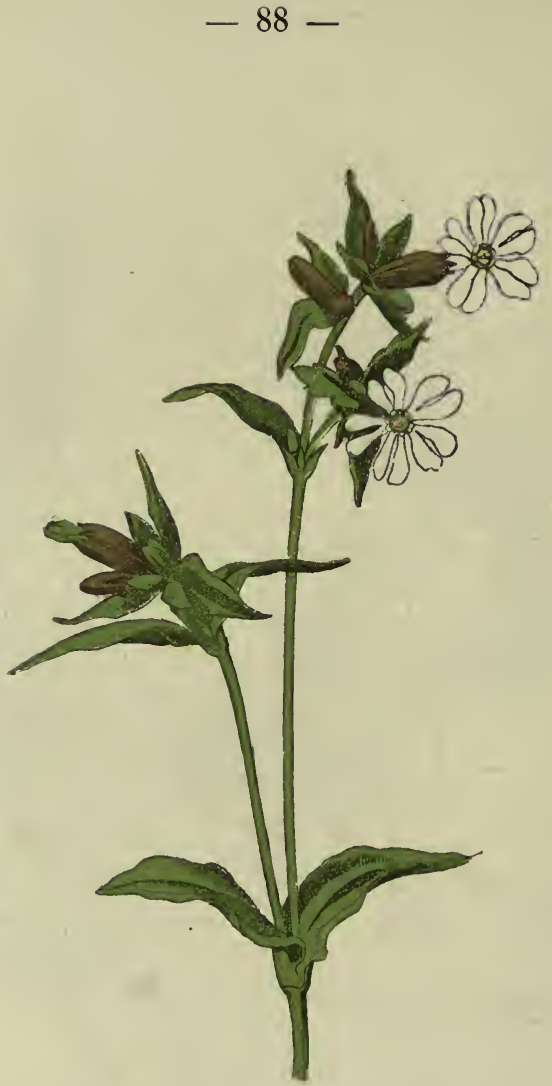

White Gampion.

Lychnis vespertina.

- Caryophyllees. - 
-being covered with flinty hooks. The rambling botanist, when playfully inclined, detaches a yard-length from the hedge and deftly throwing it against his unconscious companion's back, causes a hundred hooks to catch in the warp or weft of his coat. It belongs to the Bedstraws, a genus comprising nearly a dozen British species, and distinguished by having minute flowers, yellow, white or greenish, calyx minute, a mere ring, the corolla four or five-lobed, honeyed. Stamens four, styles two, united at their bases. The leaves are borne in whorls of from four to ten, at distant intervals on the square stem. In $G$. aparine the leaves vary from six to eight, the flower-cymes arise from their axils, the flowers are white, the fruit first green then becoming purplish. Flowers June and July.

\section{White Campion (Lychnis vespertina).}

On page 66 we gave a figure of Lychnisfos-cuculi, and descriptions of that species and $L$. diurna, the Red Campion. The present species was classed by Linnæus as a mere variety of $L$. diurna, the two being combined under the name of L. dioica. In general characters the White Campion agrees with the Red, but the calyx is more greenish, and the petals are entirely white (occasionally reddish). The plant is larger and more coarse than its diurnal relative-for, as its name signifies, $L$. vespertina opens in the evening and is fertilized by night-flying moths. It is a fragrant plant, but its fragrance is reserved for its flowering time-not that its nocturnal visitors require the scent to direct them to the flowers, for they glow and gleam in the dark field and hedgerow from May to September. 


\section{The Holly (Ilex aquifolium).}

The popular knowledge of the Holly has been gained chiefly about Christmas-tide, when its brightly varnished yet repellent leaves and its brilliant berries are much sought for household decoration. To most persons the flower is unknown; yet if they sought the holly in the woods or hedges any time from May to August they would probably find the white flowers produced in "umbellate cymes" from the axils of the leaves. The calyx is slightly downy, with four or five divisions. The petals are four in number, white, conjoined at their bases, or entirely separate. The stamens are four, one attached to the base of each petal ; stigmas also four, attached to the ovary, without intervening styles. The fruit, with which we are all so familiar by sight, is technically a drupe, in which category are also placed the cherry and the plum, fruits which have the seed enclosed in a hard "stone" (or endocarp), surrounded by a fleshy pericarp. The holly-berries, as the fruits are called (though they in no wise resemble the gooseberry, which is a true berry), contain four of such stones. This is the only British species.

The name Ilex is said to be of Celtic origin, and derived from $e c$ or $a c$, a sharp point, but this appears to us very unsatisfactory. Its old English name was holm, a word that has become fixed in some of our place-names for localities where holly is still abundant : such as Holmesdale, Holmwood, and Holmbury, all in Surrey.

If the smooth grey bark of old hollies be scrutinized closely one may find upon it a number of raised black cuneiform marks, not unlike the characters of the Chinese alphabet. They are really the fruits of a lichen, Graphis elegans. With care the piece of bark containing these curious marks may be cut out without defacing or injuring them. 
$-89-$

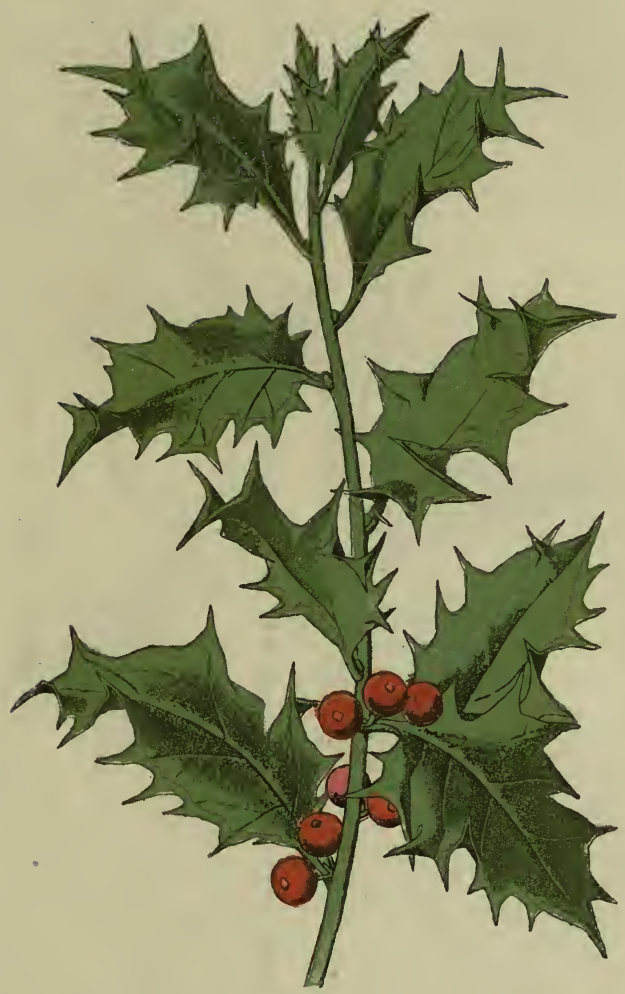

Holly.

Ilex aquifolium.

- ILIGINE 
$-90-$

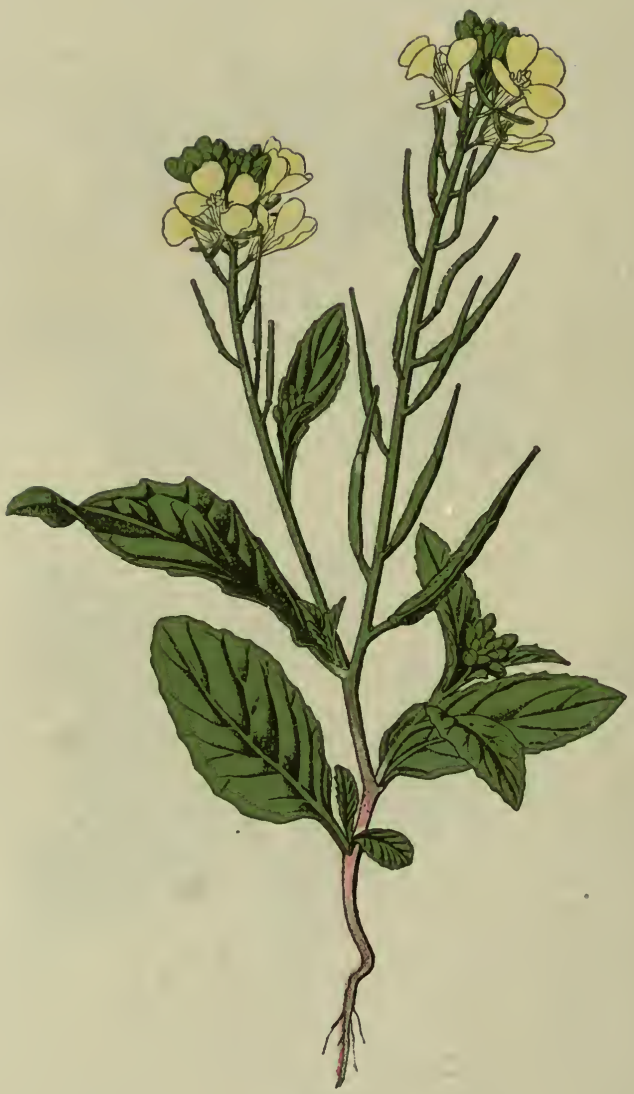

Gharlock.

Brassica sinapis.

- Cruciferæ. - 


\section{Charlock or Wild Mustard (Brassica sinapis).}

An upland cornfield in June with Charlock between the short corn-plants is a beautiful sight for the rambler, but the farmer may be pardoned if he fails to take the æsthetic view ; for all that vegetable gold must be laboriously hand-picked, or "cleaned," as he would probably express it. Charlock is a weed that keeps close to the farmer; that likes the comparatively light and dry soil of the ploughed field.

It is a hairy annual belonging to the cabbage tribe, which is a branch of the Cruciferce or Cross-worts, so-called from the four petals being arranged cross-wise. In this and the two following species the petals are bright yellow. To make the flower symmetrical there should be four or eight stamens; there are six, and it has been suggested that there were eight, but two have been suppressed. The fruit is an angular pod, with a straight beak, not persistent, and two hairy valves, but containing only one row of dark-brown seeds. Flowers from May to August.

There are many species of Brassica, two of which may be confounded with $B$. sinapis; they are :-

I. Black Mustard (B. nignum). Stem bristly, upper leaves very narrow, lanceshaped, smooth, with entire or toothed margins. Pods awl-shaped, quadrangular. Beak short and slender, containing no seeds. Valves keeled. Seeds reddish-brown, oblong. Flowers June to September in hedges and wastes.

II. White Mustard ( $B$. alba). Hairy, like $B$. sinapis, but the hairs pointing downwards. The upper leaves deeply lobed, lyre-shaped, the lobes being again cut and lobed. Stem marked with longitudinal incised lines. Pod short, no longer than the flat thin, or sword-shaped, ribbed beak. Seeds larger than the last, more globose, yellow. Flowers June and July in cultivated ground.

The genus bears the Latin name for the Cabbage, the wild form of which is B. oleracea, a wild plant on the sea-cliffs of South-west England and Wales, from which have arisen the cultivated varieties known as Scotch-kail, cow-cabbage, savoys, brussels sprouts, red cabbage, white cabbage, cauliflower and broccoli. 


\section{Common Cow-wheat (Melampyrum pratense).}

Quite a number of our common plants have been distinguished in popular nomenclature by the prefix "cow," and as a general rule it would appear to have been applied in depreciation, as in the parallel cases of "dog," "horse," and "hog," to signify coarseness or worthlessness. In the case of the Cow-wheat our forefathers had a notion that if its seeds were ground up with wheat the bread made from the flour would be black. One of the species ( $M$. arvense) affects cornfields, and its seeds are like black grains of wheat, and from this fact the genus gets its scientific appellation from the Greek, melas, black, and puros, wheat. In addition the plants themselves turn black when dead and dry.

I. Common Yellow Cow-wheat (M. pratense) is an annual, partially parasitic upon roots, like Eyebright. The leaves are almost stalkless, very narrow, with even margins, and produced in pairs. The flower follows the general structure of the Scruphulariner (see pp. 33 and 50 ante). The calyx is five-toothed, the corolla tubular, straight, dilated at the mouth and two-lipped, the upper with the edges turned back, the lower three-lobed. The four stamens will be found close under the upper lip, with the small stigma. It should be noticed that in this species, which is common in dry woods and on heaths, the pale yellow flowers assume a horizontal position, whilst the capsule is more deflexed. May to September.

II. Small-flowered Yellow Cow-wheat (M. sylvaticum) is a rare species, found in alpine woods from Yorkshire northwards. It has a small deep yellow corolla, which is borne more erectly than in pratense. Other points of difference will be found in the curved corolla-tube, and in the position of the capsule, which is not deflexed. Flowers July and August.

III. Purple Field Cow-wheat (M. arvense). This is a local species whose distribution in this country is restricted to Norfolk, Suffolk, Essex, Herts, and the Isle of Wight. Where it occurs it is a conspicuous item in the cornfield flora, by reason of its large spikes of flowers with their many colours. The bracts are reddish-purple, the corolla rosy, with yellow throat, and the lips a full pink. Flowers July and August.

IV. Crested Cow wheat ( $M$. cristatum). This also is a rare plant, confined to the Eastern counties of England, and affecting woods, copses, and cornfields. It has broad, heart-shaped, purple bracts, with long fine teeth. The flowers in a dense spike (not so large as in arvense); corolla-tube curved, yellow, the upper lip purple within. Flowers September and October. 
$-91-$

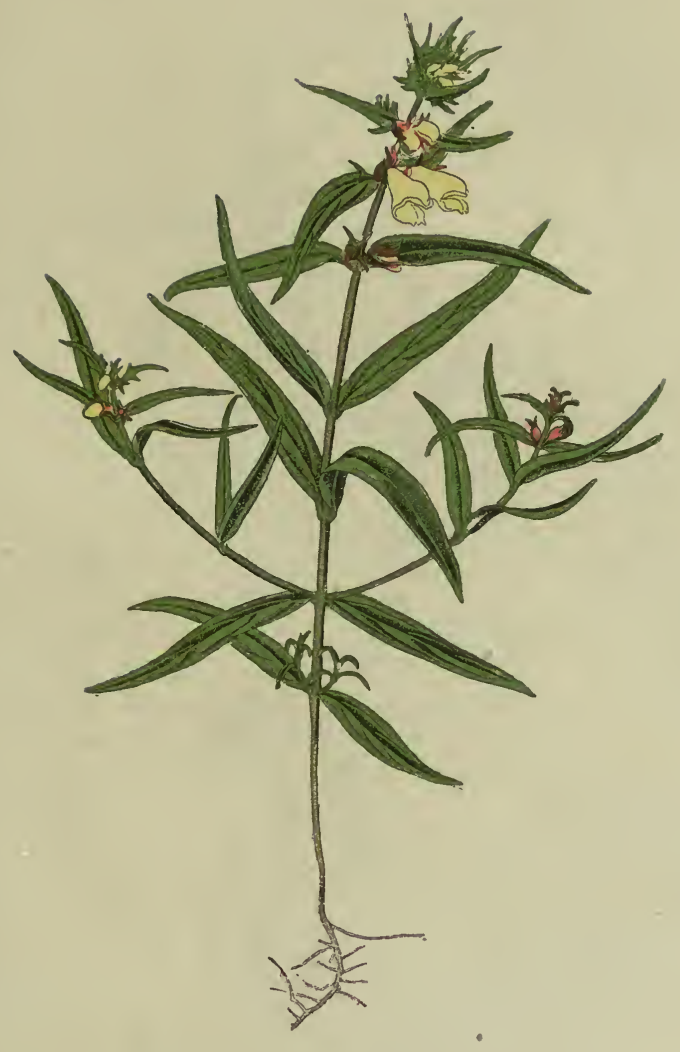

Cow-wheat.

Melampyrum pratense.

- ScrophularineÆ. - 


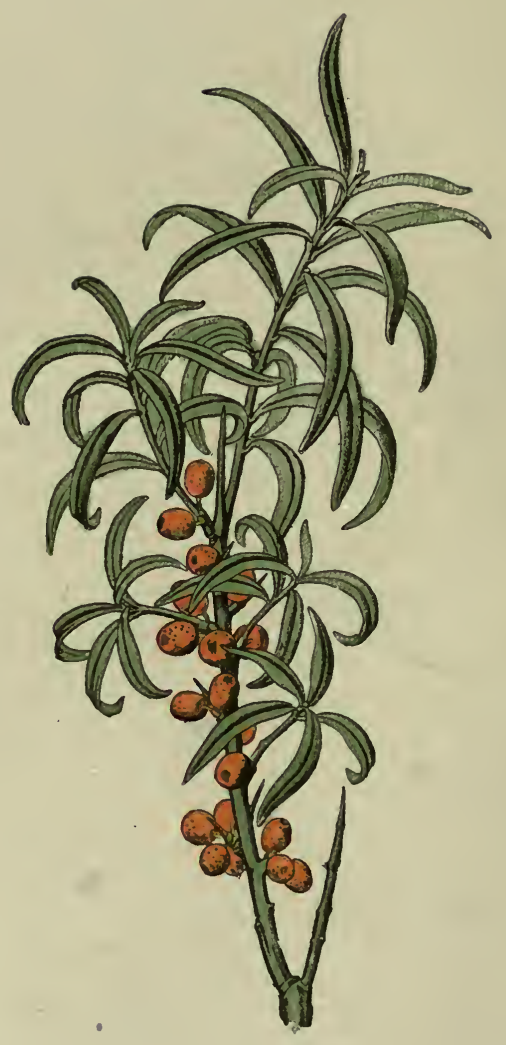

Sea Buckthorn.

Hippophae rhamnoides.

- ELAEAGNACEF. - 


\section{Sea Buckthorn (Hippophe rhamnoides).}

Let us say at once that this plant is in no way related to the Buckthorns, properly so called. It is another example of the readiness with which our fathers seized upon a mere superficial resemblance as justification for the partial repetition of a name, and to save them the trouble of finding a new one.

Sea Buckthorn is the sole representative in this country of the Natural Order Elæagnaceæ, and is a low shrubby tree, growing on sand-hills and cliffs on the East and South-east coasts from York to Sussex. The branches commonly end in a spine, which has brought the plant its alternative name of Sallow-thorn. The alternate leaves are a dull leaden green above, but the underside is covered with silvery scales. At first they are egg-shaped, but lengthen after the plant has flowered. The flowers are of two kinds, borne on separate plants (dicecious), one kind containing stamens only, the other a pistil alone. The staminate flowers are produced in clusters from the axils, and consist of two sepals with four stamens. The pistillate flowers are produced singly. The ovary is enclosed in the calyx-tube, and develops into the globose orange-yellow fruits. Flowers from May to July.

The fruits do not appear to be used in this country ; though in Tartary they are said to be made into a pleasant jelly, and in the Gulf of Bothnia they are used in the concoction of a fish-sauce. Their flavour is decidedly acid.

The name has been derived from the Greek hippos, a horse, and phao, to give light, from a supposed power of curing equine blindness; also from hippos, and phao, to destroy, from its fatal effects when eaten by horses; and from hypo, under, and phao, to shine, in allusion to the silvery underside of the leaf. The reader will kindly select that which seems the most reasonable-or reject them all. 


\section{Meadow-sweet (Spirca ulmaria).}

Our first encounter with the Queen of the Meadows, or Meadow-sweet, is an event to be remembered. It will probably be beside a shallow stream, and for a long distance we shall see the continuous line of thick clumps, with the handsome, much-divided radical leaves standing erect around the taller furrowed stems. Individually the creamy-white flowers are minute, but combined in large dense cymes they are very conspicuous. There is an airy grace about the plant that is particularly charming, quite apart from the attraction of its powerful fragrance.

Meadow-sweet has a short perennial rootstock, the leaves are interruptedly pinnate (see p. 63), the terminal leaflet threelobed. The undersides are downy and white. The stemleaves are provided with broad-toothed stipules. In spite of their fragrance the flowers produce no honey, but, attracted by the sweet odour, insects visit them in great numbers, and from the closeness of the flowers cannot help fertilizing them. The calyx has four or five lobes, turned back; the petals are four or five, the carpels vary from five to nine, curiously twisted, and surrounded by a large number of stamens. It flowers from June to August, and may be found beside watercourses and in wet meadows, as well as by the sides of streams and rivers.

There is one other British species :-

The Dropwort (Spircea filipendula), which grows far away from the haunts of the Meadow-sweet, delighting in high dry pastures, chalk downs, and gravelly heaths. He that has seen ulmaria will not fail to identify filipendula as the sister of the meadow queen, for though much smaller it is in general appearance very similar. The unopened flowers are rosy, but the inside of the petals is of the same creamywhite as in Meadow-sweet. It is not fragrant. Flowers June and July.

A third species, the Willow-leaved Spiræa ( $S$. salicifolia), may occasionally be met in plantations ; but it is not a native. 


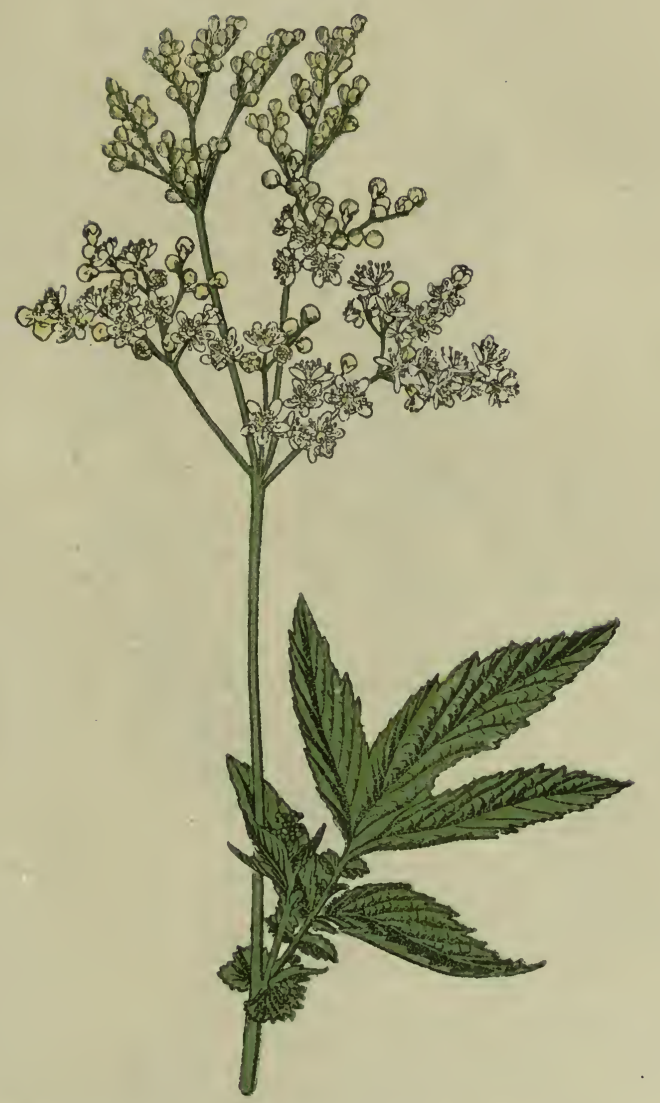

Meadow-Sweet. Queen of the Meadows. Spiræa ulmaria. 


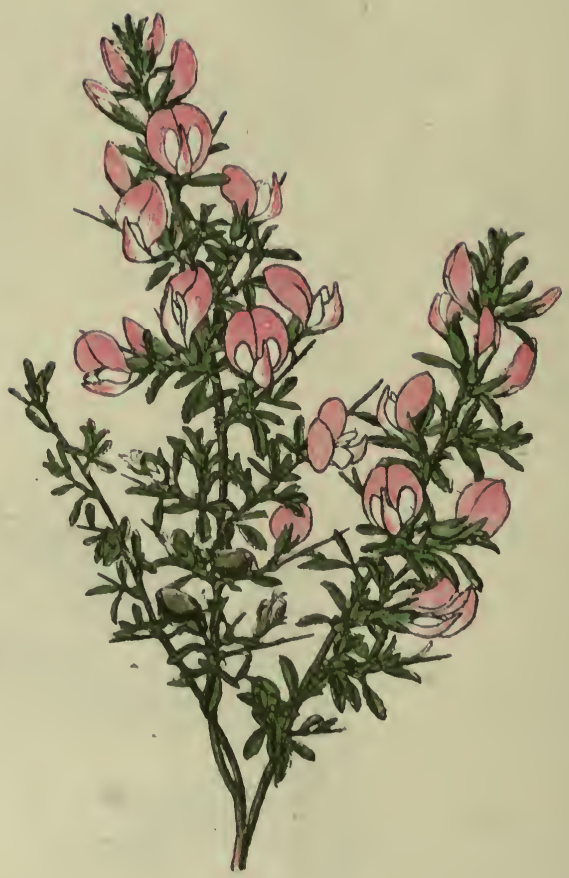

Rest Harrow.

Ononis Spinosa.

- Leguminosa. - 


\section{Rest-Harrow (Ononis spinosa).}

The Rest-Harrow or Wrest-Harrow is one of those plants whose presence in the pasture is said to indicate its poverty or the neglect of the cultivator. In Sussex and Hampshire it is known as the Cammock. It is a perennial low shrub, sometimes crceping near the ground, and at others growing more erect. The rootstock often creeps underground, a habit to which the plant owes its popular name, as it is said to bc so tough as to zurest the harrow from the even tenor of its way. The more prostrate form is covered with viscid hairs; the more erect-growing plants are spiny. In the latter condition it is said that only donkeys will eat it, and hence its scicntific name ononis, from onos, an ass, but it is open to question whether the ass has any fondness for it if he can get other food. The flowers are of the usual papilionaceous structure already described (see pp. 7, 43, 48, 50, 52, 72), and may be borne either singly or in racemes. They are pink in colour; the petal known as the standard is very large in this species, and streaked with a fuller red. The pod is very small, and in the hairy form is not so long as the calyx. The flower does not secrete honey, but in spite of this fact, it seems to be chicfly if not exclusively fertilized by bees, who are evidently fooled by its resemblance to other flowers of the same form that do offer refreshment to insect visitors. The worker-bees, however, get pollen for their pains, but the males are sadly disappointed. Rest-Harrow will be found flowering in dry wastes from June to September.

There is another species, the Small Rest-Harrow (O. reclinata), an annual with spreading hairy, viscid stems, only a few inches in length, stalked rosy flowers not half the size of spinosa, and a hairy pod as long as the calyx, or longer. It is exceedingly local, and has only been reported as occurring on sandy cliffs ir Devon, Wigton and Alderney. Flowering in June and July. 


\section{Agrimony (Agrimonia eupatoria).}

One of the prettiest of wayside plants is the golden-starred Agrimony, growing on the waste green flanks of the road and making it beautiful. It is a perennial plant, with a short woody rootstock, and "interruptedly pinnate" leaves, somewhat resembling those of the Silver-weed, the leaflets increasing in size as they near the terminal leaflet. The flowers are borne on that kind of inflorescence called a raceme, in which each flower is attached to the central stem by a stalk of its own. Were these stalks suppressed the inflorescence would be termed a spike, and indeed some authors have so described the flower-clustering of Agrimony. The flowers are little roses, and consist of a top-shaped spiny calyx, tubular, with contracted mouth and five overlapping lobes; five golden petals, ten or more stamens, and two carpels sunk in the calyxtube, their styles and two-lobed stigmas protruding. They do not secrete honey, and are seldom visited by insects.

As the lower fruits ripen the raceme lengthens, and concurrently the calyx-tubes harden and assume a drooping position, owing to the downward curving of their little footstalks.

There is a variety with resinous-scented, larger, more crowded flowers, of local occurrence. Agrimony was formerly held in some repute as a medicinal plant, and from this circumstance it gets its name. The ancient Greeks had a word argema signifying the affection of the eyes to which we apply the term cataract, and a plant which was reputed to cure argema they called argemone, a word which has since been corrupted into agrimony. "Yarb doctors" still give it a place in their pharmacopœia.

Agrimony flowers from June to September. 
$-95-$

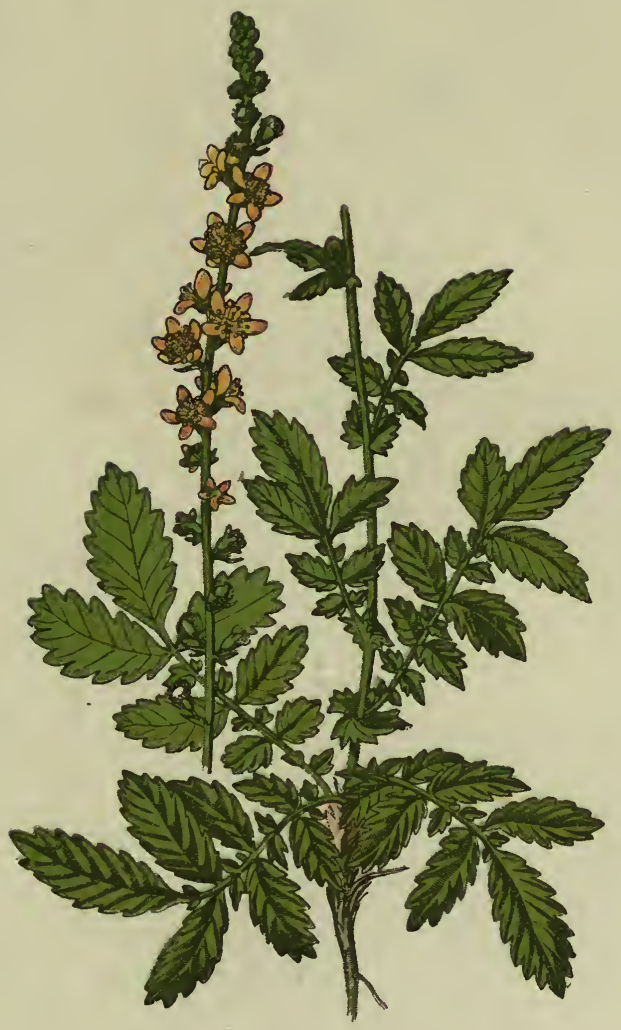

Agrimony.

Agrimonia eupatoria.

- ROSACEA. - 
$-96-$

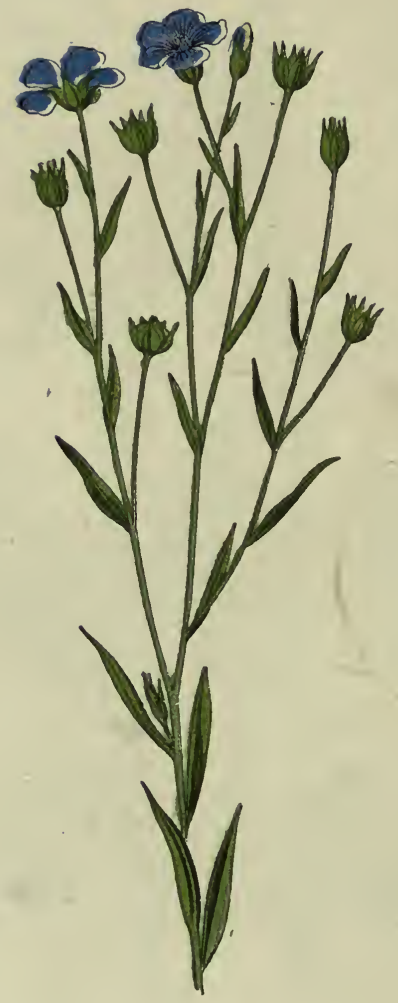

Common Flax.

Linum usitatissimum.

- LINEAE. - 


\section{Common Flax (Linum usitatissimum).}

Occasionally the rambler will find the Flax in cornfields and wastes, by oil-mills and in the neighbourhood of railway stations. Wherever it may be found it is an escape from cultivation. As a truly wild plant the "most used" flax is not known : in cultivation, as the parent of linen garments, it has been known from the infancy of the human race. To-day the exports of flax and linen from the United Kingdom are worth about $£ 5,500,000$ per annum. It is therefore a plant that would be entitled to respectful consideration when we meet it, even if it had no grace or beauty to commend it to us.

Common Flax is an annual plant, with erect slender stems about a foot and a half high. Its narrow lance-shaped leaves are arranged alternately and at a distance from each other. The flowers are large, and purplish-blue in colour. Five is the number dominating the structure of the flower : sepals, petals, stamens, glands, ovary ( 5 cells), styles-all in fives. It flowers in June and July.

There are three other species that are truly wild in Britain :-

I. Purging Flax (L. catharticum). A smaller species, half a foot high, with white flowers, affecting heaths and pastures. It has opposite, very narrow leaves, and the unopened buds nod. Flowers June to September.

II. Perennial Flax (L. perenne). A very rare perennial plant with exceedingly narrow leaves, alternate on the numerous wiry stems. Plant about 2 feet high. The large bright-blue flowers, which may be found from June to September, are of two forms, long-styled and short-styled, like the Primroses (see p. 2), and for a similar purpose. On chalky soils from Durham to Essex.

III. Narrow-leaved Flax ( $L$. angustifolium). Leaves alternate, as narrow as in the last species, but smaller and not so plentiful. Flowers smaller and paler, petals smaller in proportion to the calyx. Flowers May to September. Sandy and chalky pastures, not farther north than Lancashire. 


\section{Long-rooted Cat's-ear (Hypocheris radicata).}

Cat's-ear is one of those plants that are passed by the rambler as being "perplexing hawkweeds which no one but a German botanist understands." It is not exactly a hawkweed, though it comes pretty close to that family, and roughly may be said to resemble them. Of the Composite flowers we have already dealt with, it will be seen that the Cat's-ear has a blossom similar in structure to Sonchus (page I 14), Taraxacum (page 20) and Tragopogon (page 84). It has a perennial tap-root, from which arises and spreads a circlet of many rough hairy leaves, their edges scalloped; there are no stem leaves. The flower-stem is branched, each branch bearing but one flowerhead. The involucral bracts are in several series, laid one over the other like tiles. All the corollas are strap-shaped, toothed at the free end, yellow. The pappus or down that surrounds the fruit consists of a row of feathery hairs, surrounded by an outer row of shorter bristles. The flowers are longer than the involucre. Flowers June to September. There are two other British species :-

I. Smooth Cat's-ear ( $H$. glabra). An annual plant, found chiefly in dry fields on gravelly soil, but not nearly so commonly as radicata. Its leaves are broader, eggshaped, and smooth. It has several branched flower-stems. The involucre as long as the florets, the bracts few and unequal. Flowers June to September.

II. Spotted Cat's-ear ( $H$. maculata). A rare perennial, confined to chalky and limestone pastures in several counties, i.e., the Lizard, Cornwall ; Orme's head, North Wales; Westmoreland, Cambridgeshire, Suffolk, Essex. Leaves rough, with hairs, stalkless, egg-shaped, often spotted. Flower-stems seldom branched, usually with several small leaves and one large flower-hend (sometimes several). Involucre shorter than the florets; outer row of pappus absent. Flowers July and August. 

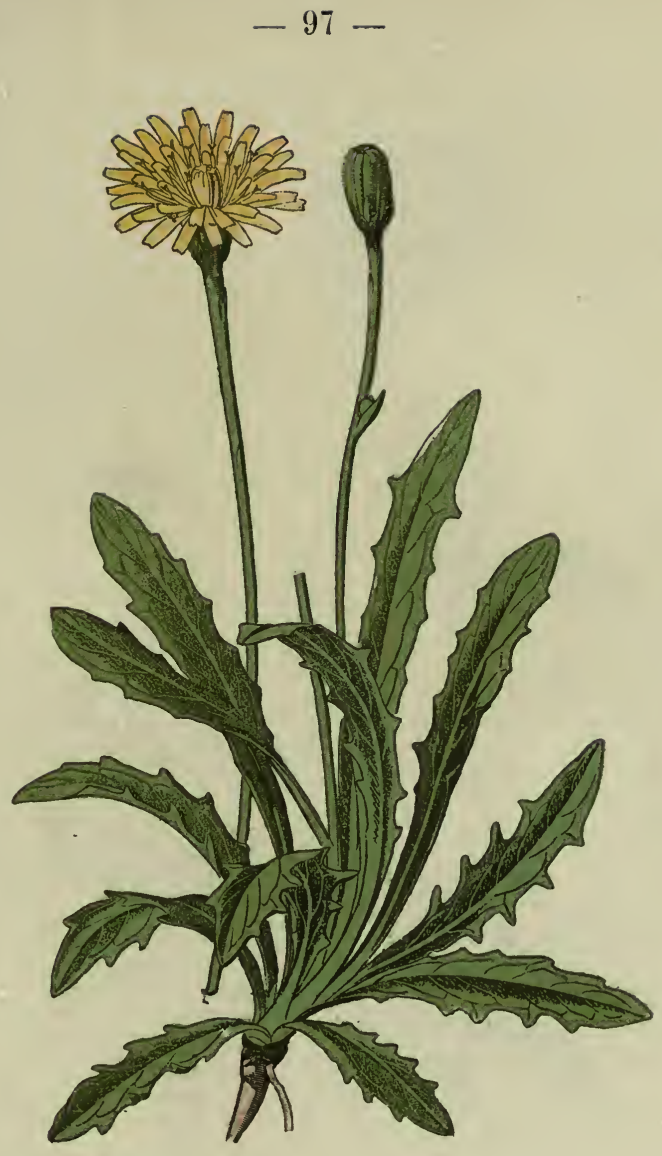

Cat's-Ear.

Hypochæris radicata.

- Composite. - 


\section{$-98-$}

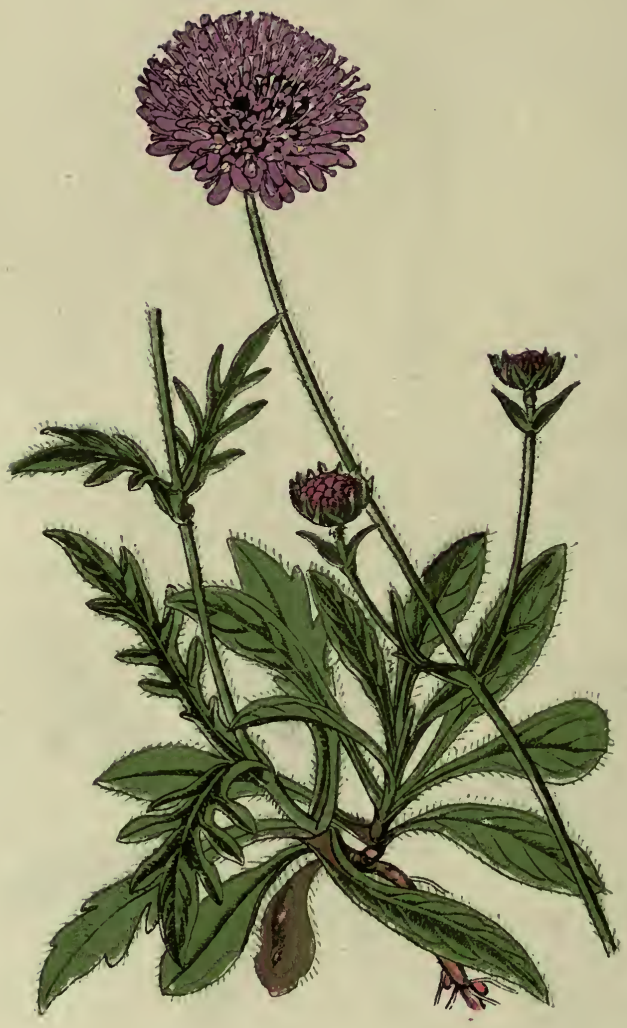

Field Scabious.

Scabiosa arvensis.

- Dipsace A. - 


\section{The Field Scabious (Scabiosa arvensis).}

Should any reader who has not previously made a study of botany, but who has followed us thus far, be asked to name the order to which the Scabious belongs, he would almost certainly say the Compositæ. He would be wrong, but almost right. Scabious is certainly a Composite flower, though not one of the Compositæ; it is, instead, included in the order Dipsaceæ. We have already made the acquaintance of so many composite flowers that our readers may be presumed to be fairly familiar with their general structure. It will be remembered, then, that the anthers of Composites are all joined together to form a tube : in Dipsaceæ they are free. Again, the calyx in Compositæ is reduced to a series of hairs ( $p a p p u s$ ), whilst in Dipsacer there is a distinct tubular calyx invested in a separate involucel (or little involucre) of tiny bracts, quite independent of the common involucre that invests the whole head of florets.

I. The Field Scabious (S. arvensis), is a perennial with a stout rootstock, and a hairy stem. The leaves vary considerably in different specimens, but usually those from the root are entire, of an oblong lance-shape, with toothed margins. The stem leaves are lobed, sometimes almost pinnate. The flower-heads are borne on a long stout stalk, and consist of about fifty florets, increasing in size from the centre to the outer margin, and of a pale blue or lilac colour, the central ones more inclined to red; anthers yellow. Involucral bracts broad and leaf-like, in two rows. Dry fields and downs. June to September.

II. Devil's-bit Scabious (S. succisa). Rootstock short, coming to an abrupt conclusion, as though bitten off. Culpepper accounts for this and the name by saying : "This root was longer, until the Devil (as the friars say), bit away the rest from spite, envying its usefulness to mankind; for sure he was not troubled with any disease for which it is proper." Leaves all entire. Involucral bracts lance-shaped. shorter than the corollas, in two or three rows. Anthers reddish-brown. Florets nearly equal in size. Flowers purplish-blue, sometimes white. July to October, in meadows and pastures.

III. Small Scabious (S. columbaria). Rootstuck thick and woody. Root leaves entire, narrow ; stem leaves deeply cut, almost pinnate. Involucral bracts longer than the corollas, in one row. Corollas five-lobed (in the other species four-lobed), the outer row considerably larger than the inner ones, and of irregular form. Anthers yellow, corollas purplish-blue. July to September, in pastures and wastes.

The name is derived from the Latin, scabies, the itch, it heing formerly used in curing this and other cutaneous disorders. 


\section{Bitter Sweet (Solanum dulcamara).}

One of the most familiar objects in the hedge is the trailing stem and variously-shaped leaves of the Bitter Sweet or Woody Nightshade; the singular flowers or the red berries attract our attention at once. This and the Common or Black Nightshade are the sole British representatives of a genus that includes the Potato among other valuable exotic species.

Bitter Sweet is a perennial, with a creeping rootstock, from which arise the long trailing stems that have no means of climbing in the shape of tendrils, hooks, prickles, or the power of twining, but yet by leaning against the stouter hedge plants manage to attain a height of four or five feet. The leaves vary much, the lowest being heart-shaped, the upper more or less spear-shaped, with gradations between these forms. They are very dark green in colour, and all stalked. The calyx is fiveparted; the purple corolla with five lobes, each having at its base two small green tubercles. The five yellow anthers have their edges united, so that they form a pyramidal tube, through which the style protrudes. The anthers discharge their pollen by terminal pores. The succeeding berries are egg-shaped, and go through a series of colour-changes from green through yellow and orange to a fine red. The popular name is founded upon a peculiarity which we have never tested: it is said the stems when tasted are first bitter, then the sensation changes to one of pleasant sweetness. Flowers June to September.

The Common or Black Nightshade (S. nigrum) is an annual with an erect stem, about 2 feet in height. Its leaves are egg-shaped, the blade gradually narrowing to the stalk, with a waved or toothed margin. The corolla is white, the berries rounder, usualiy black, but sometimes yellow or red. Fields and waste places. From July to October. 
$-99-$

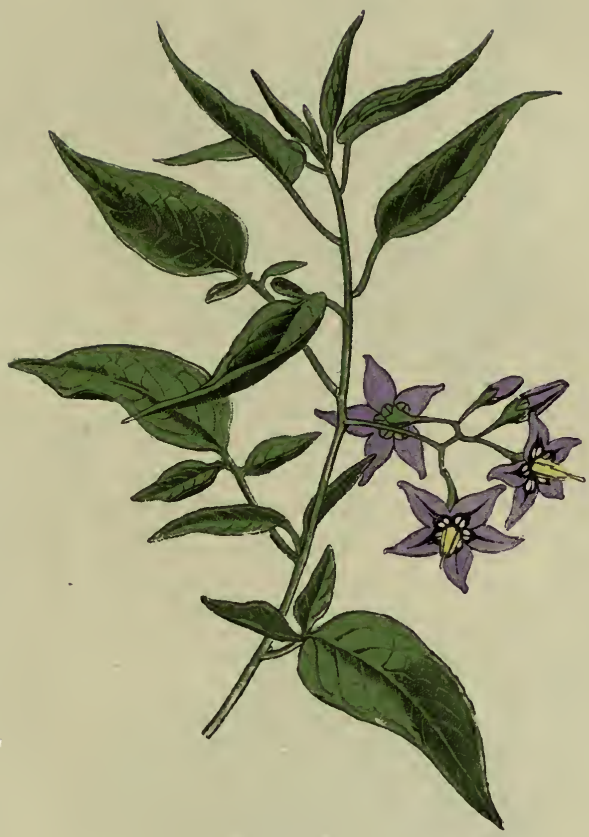

Bitter-Sweet.

Solanum dulcamara.

- SolanAceA. - 


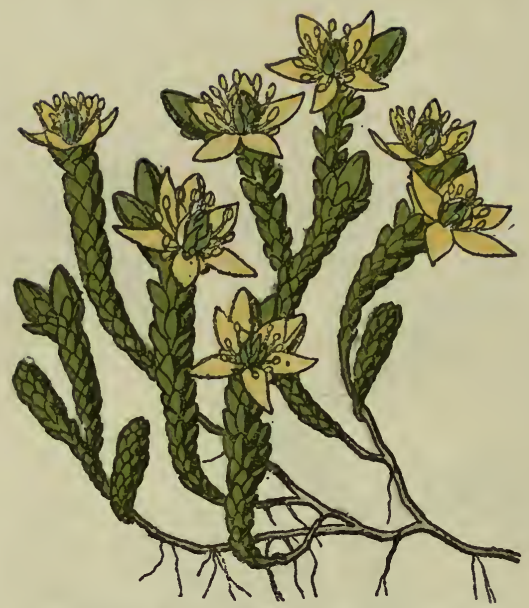

A. - Biting Stonecrop. Wall pepper. Sedum acre.

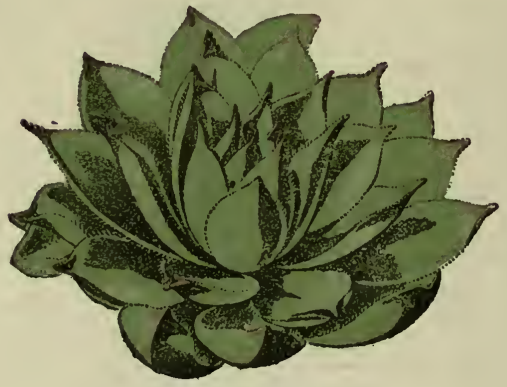

I3. - House-leek.

Sempervivum tectorum.

- Crassulace. 


\section{Biting Stonecrop (Sedum acre).}

Of the eight British species of Sedum, and the two or three additional kinds that have escaped from gardens and become locally naturalized, this is the best known. Rocks and old walls are its favourite resorts, the stems growing downwards and curving outwards. The leaves are small, thick, produced into a kind of spur at the base, and closely pressing the older on the newer. The calyx is in one with five lobes, the corolla consists of five distinct golden yellow petals: stamens ten, with yellow anthers; carpels five, united at their bases. Flowers June and July. Another popular name for it is Wall Pepper, both names being due to the acrid taste.

The scientific name is from the Latin sedeo, to sit, from the peculiar habit of the plant.

\section{Houseleek (Sempervivum tectorum).}

Although the Houseleek is not a true native of Britain it has been so long established on old walls and the roofs of out-houses that it is quite a familiar object in a country ramble. As its scientific name (from semper, always, and vivum, fresh, green) indicates, it dies hard, and alike endures frost and drought. The story is told of one that a botanist tried hard for eighteen months to dry for his herbarium, but failing in his object planted it again, and it grew as though nothing had occurred to interfere with its ordinary life. The leaves are borne on the flowerless stems in the form of a rosette, the oldest flat, the youngest erect; thick, fleshy, the edges purple, tips sharply pointed. Flowering stems with alternate leaves; flowers dull purple in cymes. Sepals twelve, petals twelve, stamens twenty-four, but twelve of these are imperfect or aborted. Flowers June and July. 


\section{Yellow Melilot (Melilotus officinalis).}

Occasionally on roadside wastes, railway banks and similar refuges for the vagabonds of plant-life, especially if it be in the Eastern counties, the rambler comes across a slender plant with loosely trifoliate leaves on long stalks, and long narrow racemes of pale yellow flowers. These flowers, considered individually, are seen to be shaped like several we have already considered (see page 43), with a certain amount of variation, of course. This is the Common Yellow Melilot, a plant that is not truly indigenous, but one that has been cultivated in this country for a great number of years, and of which some escapes from the meadows have settled like gipsy squatters on the unenclosed wastes. But the field-path rambler is sure to come across it in the meadows, so it is as well that he should know it. It will be at once noted that the flowers are all drooping from the flower-stem, and that when the petals drop off they reveal a similarly drooping olive-coloured pod, which is small, eggshaped and rough, with transverse ribs. In the process of drying Melilot develops an odour similar to that of the Sweet Vernal-grass that gives the pleasant scent to new-mown hay. Flowers June to August.

There are two truly indigenous species :-

I. Tall Melilot (M. altissima), with deep yellow flowers. Pod compressed, covered with net-like markings, hairy, black when ripe. Fields. June to August.

II. White Melilot (M. alba). More slender than the last, with smaller white flowers. Pod stouter, smooth, black. Waste places. July and August.

The name of the genus is compounded of mel, honey, and lotus, the name of another genus $=$ the lotus with the sweet or honeyed smell. 


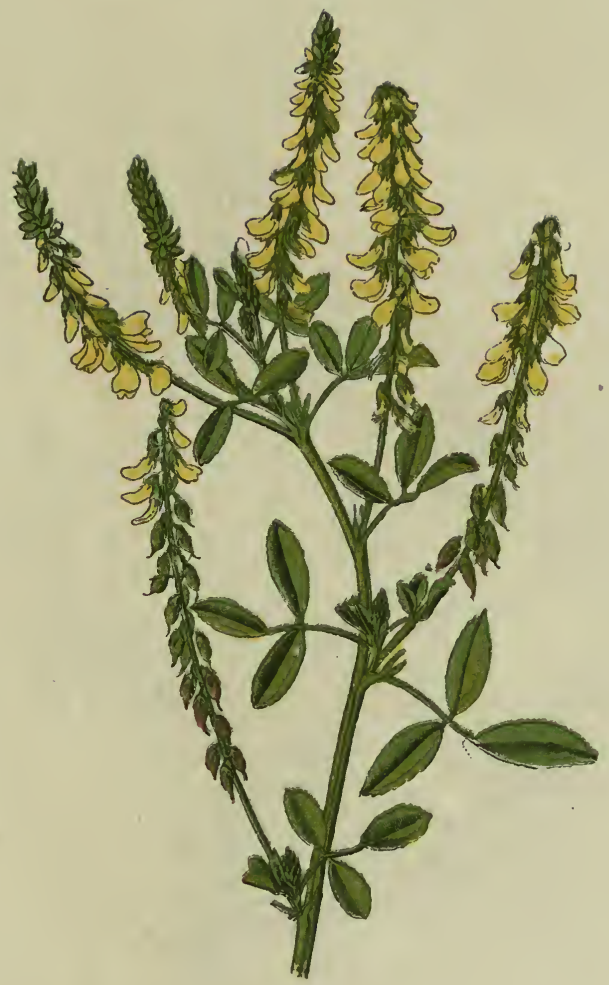

Field Melilot.

Melilotus officinalis.

- Leguminos E. - 


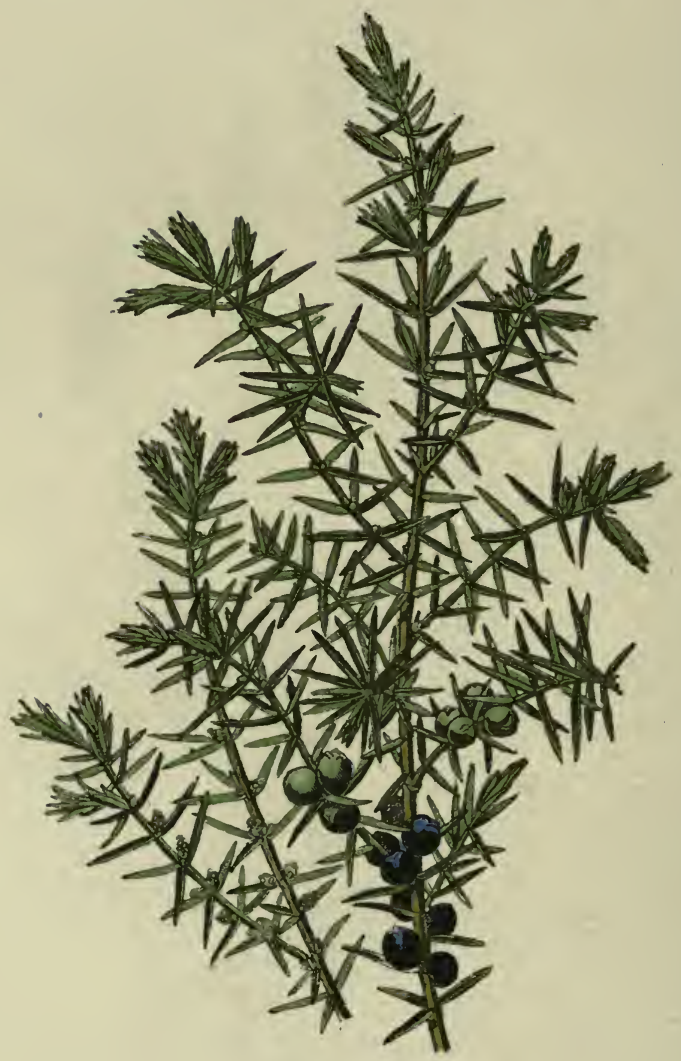

Juniper.

Juniperus communis.

- Conifera. - 


\section{Juniper (Juniperus communis).}

Hitherto we have been considering plants that have stigmas and ovaries, whether they had or had not a calyx or a corolla ; but we must now introduce our patient readers to a cohort of plants which contrive to make an important figure in the world without either calyx, corolla, stigma, or ovary. These plants are generally forest trees, most important as timber producers, but their flowers consist solely of anthers and open carpels containing the ovules, which are fertilized by actual contact with the pollen-grains, instead of through the medium of a stigma and style which have to be pierced by the pollen-tube. This cohort. contains the pines and firs; also the Juniper and the Yew.

Juniper is a dark foliaged evergreen shrub or small tree, usually four or five feet in height, but occasionally attaining a stature of ten, fifteen, or even twenty feet. It occurs on heaths and open hillsides, sometimes in great profusion, as on parts of the North Downs in Surrey and Kent. Its leaves are very narrow, pointed, and borne in threes. Their midribs and margins are thicker than the intermediate portions, and they have a pungent resinous odour. Each anther is borne on a scale, a number of which are formed into a cone, and is fourcelled. The female flower consists of five or six scales united at their bases to form a kind of involucre, within which are three naked ovules. The pale yellow pollen is blown into this by the wind, and falls directly upon the ovules. Having become fertile the seeds mature, and the scales develop into a fleshy cone, outwardly resembling a berry, of a blue-black hue with a glaucous bloom upon it. The pollen is shed in May and June, but the fruit is not ripe until the following spring. This is the only British species ; its essential oil has long been used as a diuretic and flavouring substance, notably for giving its distinctive flavour to Gin, whose name is derived from Genevrier, the French for Juniper. 


\section{Stinging Nettles (Urtica).}

Surely, the reader says, we know a nettle when we see it, and certainly know it when we touch it, without needing description or figure. Perhaps so, but the average rambler, for whom this book is primarily intended, would certainly pass Campanula trachelium as a nettle if he encountered it before it flowered; and though he may know a nettle by being stung, he cannot in that simple manner determine the species, for there are three kinds occurring in England. We will, however, meet the objection so far that we will not waste many words in a general description, but deal more with the points of difference between the species. All have a liberal supply of the stinging hairs, and green flowers of two kinds. The staminate flowers consist of a four-parted perianth enclosing four stamens with kidney-shaped anthers. Pistillate flowers consist of a perianth and a single carpel, surmounted by a brush-like stigma. The name of the genus is from the Latin uro, to burn, in reference to the sensation produced by the stings.

I. The Great Nettle (Urtica dioica), is the species figured. It is our largest native nettle, and attains the height of 4 or 5 feet, the stem rising from a branching perennial rootstock which throws out runners, The large leaves are saw-edged, and apart from the stinging hairs are downy. Flower spikes given off in pairs, each spike consisting of either staminate or pistillate flowers only; the pistillate more dense than the others. Hedgebanks chiefly. Flowering from June to September.

II. Roman Nettle ( $U$. pilulifera). Not so large. An annual; leaves smooth but for the stinging hairs, margin entire or toothed. Male flowers in panicles, $f$ emale gathered in heads. Flowers larger than in dioica. Under walls and among rubbish, near habitations, chiefly in the Eastern counties, and near the sea. June to August.

III. Small Nettle (U. urens). The familiar annual plant of fields and wastes. Leaves cuarsely toothed, smooth but for stinging hairs. Panicles containing flowers of both sexes; few flowered. Flowers June to September. 
$-103-$

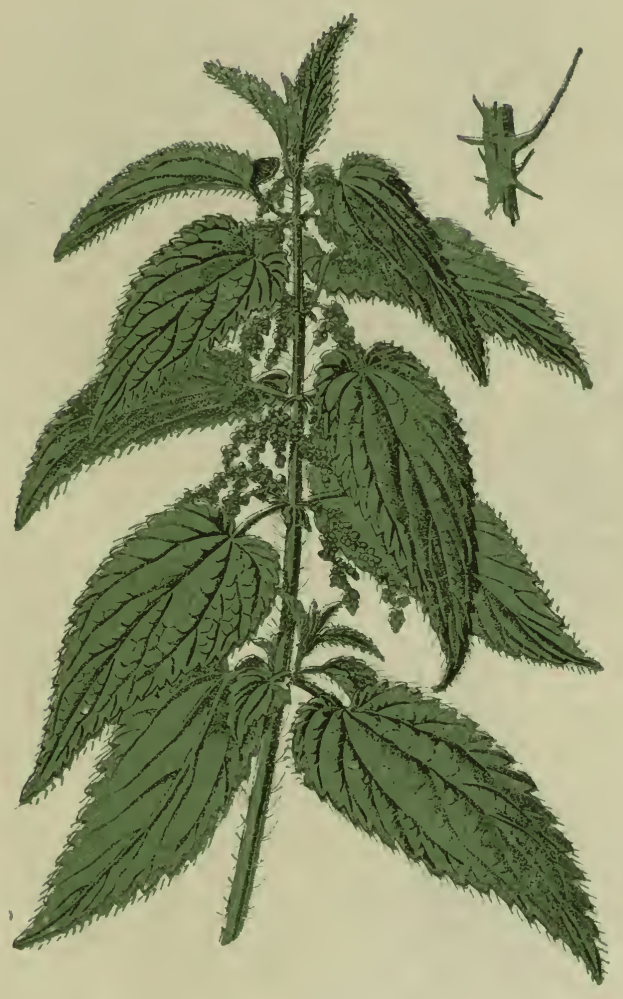

Great Stinging Nettle.

Urtica dioica.

- URticace $A$. - 
$-104-$

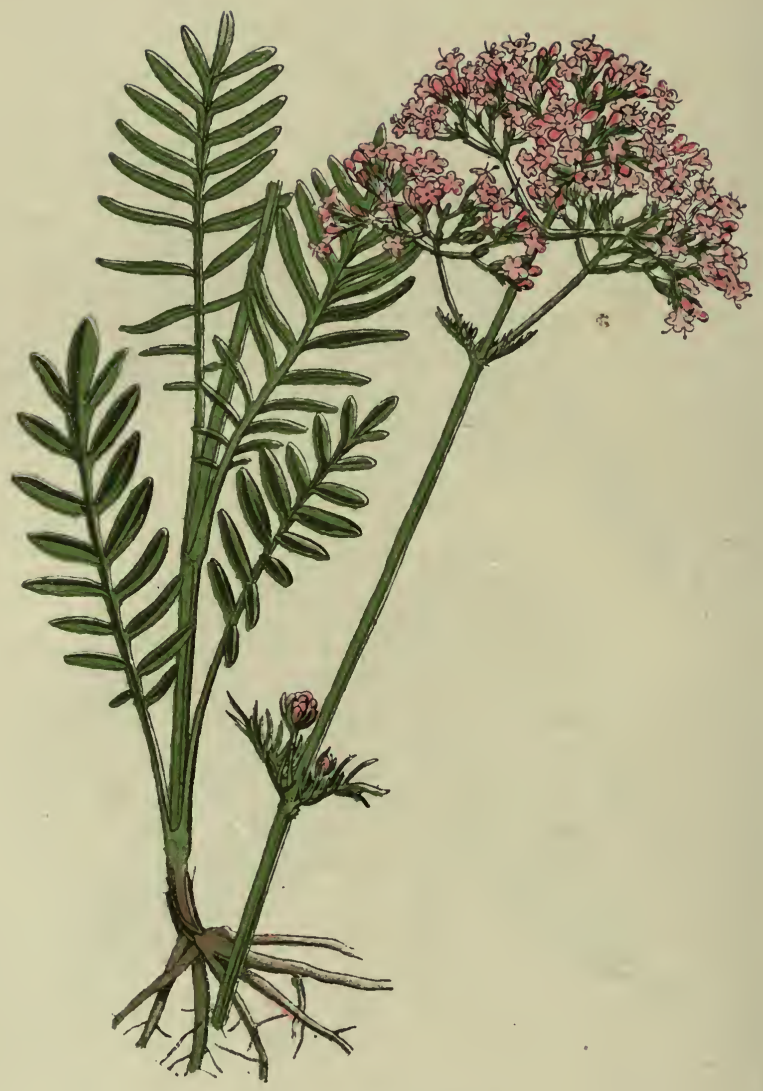

Cat's Valerian.

Valeriana officinalis.

- VAleriaNAE. - 


\section{Cat's Yalerian (Valeriana officinalis).}

The Great or Cat's Valerian will come under the notice of the rambler whose way lies by the stream-side, through wet meadows or swampy woods. Where it is found it occurs in abundance, and its pretty flowers massed together in great heads will attract attention at once. It has a short perennial rootstock, increasing by suckers, and narrow pinnate leaves, those from the root soon withering. The stems are from two to four feet high, bearing the broad corymbs of pink or fleshcoloured flowers. The calyx is five-parted, and the lobes are at first rolled inward, but as the fruit matures these lobes expand and assume the form of a circlet of finely branched feathery hairs (pappus). The corolla is shortly tubular, with five lobes. The stamens three, and the stigma two-lobed. It flowers from June to August.

The roots have long been held in high esteem as a medicinal agent in certain nervous affections; and in some places the plant is known as All-heal, owing to its virtues. It has a warm aromatic taste, but when drying it develops a foetid odour, which acts as a charm upon cats. If the reader would have cheerful nights let him plant Valerian in his garden, and every cat in the neighbourhood will call to enjoy it. Strange to say, rats are equally delighted with its fragrance, and rat-catchers are said to use Valerian to assist them in attracting their victims. Query : Had the Pied-piper a root of Valerian in his poke?

There is one other native species, the Small Marsh Valerian ( $V$. dioica), chiefly affecting boggy places. It has a creeping rootstock, and the root leaves are eggshaped, with a long footstalk, whilst those of the stem are deeply lobed in pinnate fashion, with a large leaflet at the tip. The flowers, which are pink, are minute, and of four distinct kinds, which may be thus enumerated according to the size of the corolla. I. Large, with anthers, but no pistil. 2. Small, with anthers and rudimentary pistil. 3. Smaller, with pistil and rudimentary anthers. 4. Smallest, with pistil, but no anthers. Flowers May and June.

The name is from the Latin, valere, to be in health. 


\section{Yellow Toadflax (Linaria vulgaris).}

We have already dealt with one species of Toadflax (see page 33), and although in habit the Ivy-leaved is altogether unlike the Yellow Toadflax, their flowers will be found to have the same structure, and we must ask the reader to refer back for the description. The Yellow Toadflax (L. viilgaris) immediately reminds one of the Snapdragon (Anterrhinum), to which its raceme of flowers. bears close resemblance; but the flowers themselves will be found to differ from Snapdragon in having a long tail or spur. This spur is a hollow tube in which honey is secreted to attract long-tongued bees, in order that they may fertilize the ovules. The plant has a slender rootstock, which creeps extensively underground, branching and sending up many stems. If these get into a garden the owner is at first delighted with the neat, bright appearance of the tufts of linear leaves; but by-and-by he finds it has taken entire possession of the bed, and become extremely difficult to extirpate. It is abundant in hedges and waste places, flowering from June till October. Other species are :-

I. Round-leaved Toadflax (L. spuria) with egg-shaped or round leaves and trailing branches: hairy. Corolla yellow, with purple throat and spur greatly curved. Annual. Sandy cornfields. July to October.

II. Sharp-pointed Toadflax (L. elatine), with spear-shaped leaves and trailing hairy branches. Corolla yellow, upper lip purple beneath. Spur straight. Annual. Dry, chalky and gravelly cornfields. July to October.

III. Pale-blue Toadflax (L. repens). Perennial. Smooth. Rootstock creeping. Leaves narrowly lance-shaped. Corolla violet, with darker lines and yellow palate : spur blunt. Waste places, rare. July to September.

IV. Small Toadflax (L. minor). Annual. Downy. Leaves narrowly oblong. Corolla but slightly larger than the calyx, 


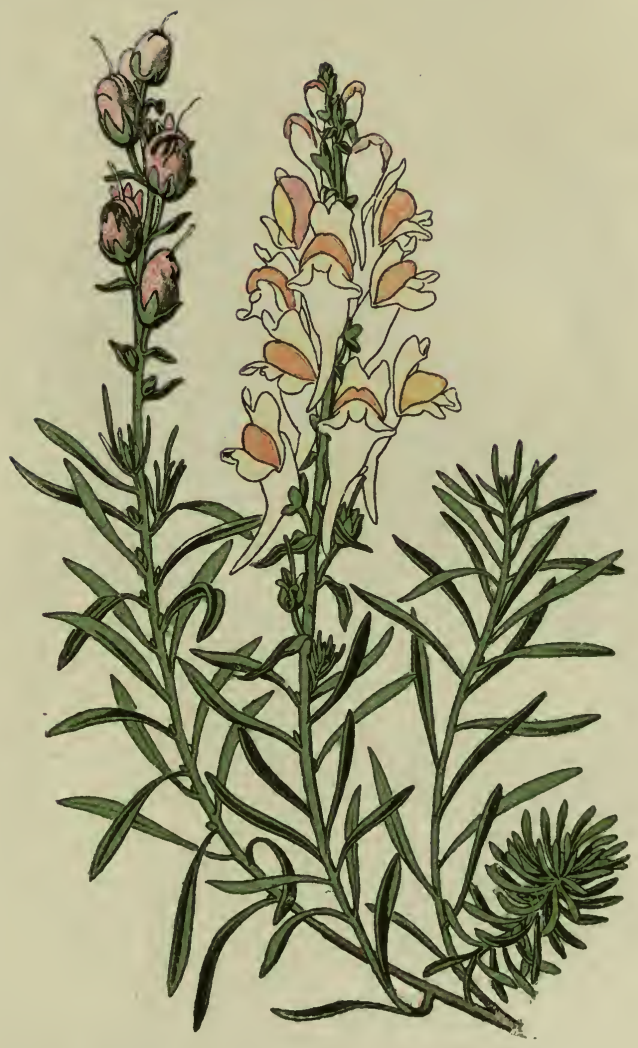

Common Toadflax.

Linaria vulgaris.

- SGrophUlarineæ. - 
$-106-$

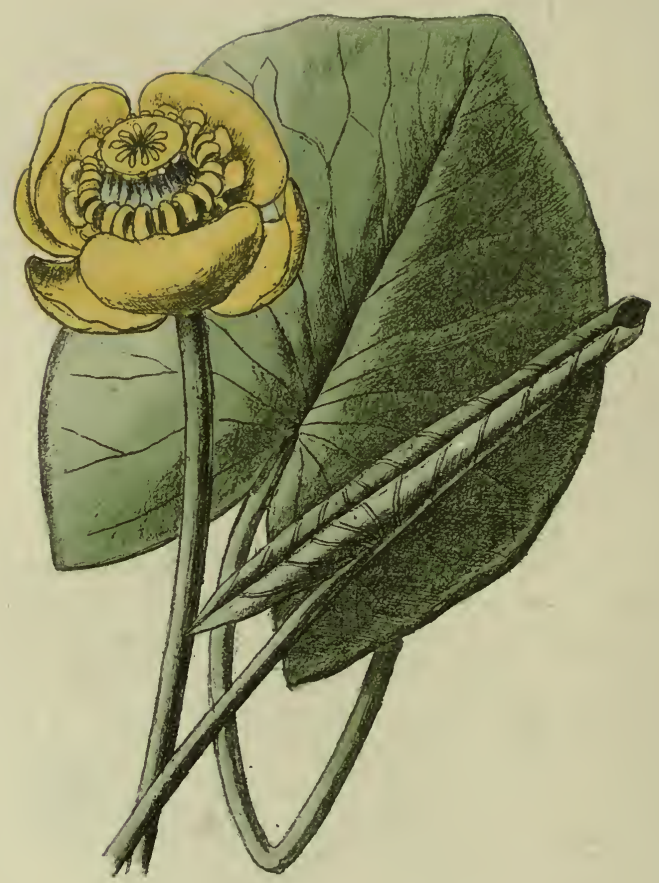

Yellow Waterlily.

Nuphar luteum.

- NympheaceA. - 
purple, the lower lip white, and the palate yellow. Local, in sandy and chalky cornfields. From May to October.

\section{Yellow Water-lily (Nuphar luteun).}

In some districts, where the Yellow Water-lily floats on the bosom of ponds and sluggish streams, it is known as the Brandy-bottle, partly by reason of its unpleasant odour and partly on account of its flagon-like seed-vessel.

It has a thick fleshy rootstock, which creeps in the mud, and is rich in tannic acid; it is said to be a fatal lure to cockroaches if bruised and soaked in milk. Some of the leaves are submerged, and these are thin, but the floating ones are thick and leathery. The leaves are heart-shaped, the lobes not far apart ; the stalks somewhat triangular in section, and traversed by a great number of fine air-canals, as are the flower-stalks also. The most conspicuous portion of the flower is the sepals, five or six in number, which are very large and concave. The petals are much smaller, and number about twenty ; they produce honey at their base. The stamens are even more numerous than the petals, in several rows, their blunt tips bent over away from the many-celled ovary. The stigma is rayed. The fruit ripens above water, and is, as we have indicated, flagon-shaped; the seeds are imbedded in pulp. Flowers from June till August.

There is another species :-

The Lesser Yellow Water-lily $(N \cdot$ pumilum), which occurs in Shropshire and in Scotland, from Elgin to Argyll, but it is rare. Its oblong leaves are divided at the base, the lobes becoming distant from each other. The petals are rounder than in luteum, the anthers shorter, and the rays of the stigma reach to the margin, which is lobed.

The name is from the Arabic for this or a similar plant, naufar.

The White Water-lily (Nymphaca alba), though constituting the British representative of a distinct genus, is closely allied, as, indeed, is the magnificent Victoria regia of South American rivers, with leaves 1o or 12 feet across, and fowers 15 inches and more in diameter. 


\section{Wild Teasel (Dipsacus sylvestris).}

We have explained (page 98) in what respect the Scabious differs from the somewhat similar flowers of Compositæ, and to a considerable extent that explanation will hold good for the genus Dipsacus, which is united to Scabiosa in the Natural Order Dipsaceæ. There is this difference, however: in Dipsacus the flower-bracts end in long, straight, sharp points, and the involucel is four-angled. There are two British species :-

I. Wild Teasel ( $D$. sylvestris). A striking object in copse or hedgerow ; its stout, angular and spiny stems rising to a height of 4 or 5 feet, and crowned by the prickly-cylindrical heads of flowers. These heads have an involucre, consisting of from eight to twelve slender rigid bracts, spiny, longer than the flower-head, curved upward and ending in a fine point. The corolla is purple, tubular; with four short unequal lobes. It is a biennial plant, and only has radical leaves during its first year, sending up the flowering stem the second season. These are stalked, lance-shaped, with a stout mid-rib, which is armed with short curved spines. 'The stem-leaves are opposite, not stalked, the lower couples joined together by their bases, thus forming a large cup, in which rain collects and drowns many insects that attempt to ascend the tall stem. Flowers August and September. The Fuller's Teasel (D. fullonum), of so great importance to the cloth manufacturer, is believed to be a cultivated variety of sylvestris, having the involucral bracts shorter and spreading, and the scales of the flower-heads hooked.

II. Small Teasel ( $D$. pilosus). This is a more slender plant, the stem not so tall or stout, and the prickles ending in soft hair-points. Leaves stalked, hairy. Flowerheads at first drooping, then erect; smaller, rounder, hairy, the involucral bracts shorter than the head. Flowers white. August and September, in moist hedges; not so generally distributed as sjlvestris. 
$-107-$

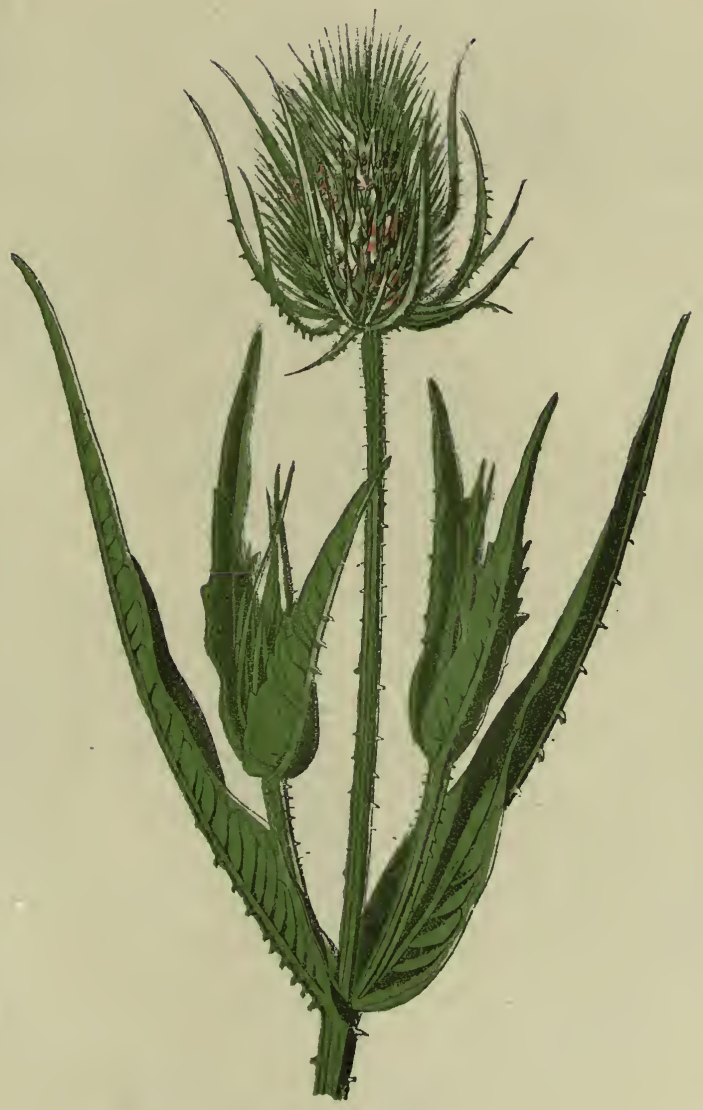

Wild Teasel.

Dipsacus Sylvestris.

- DiPsacez. - 


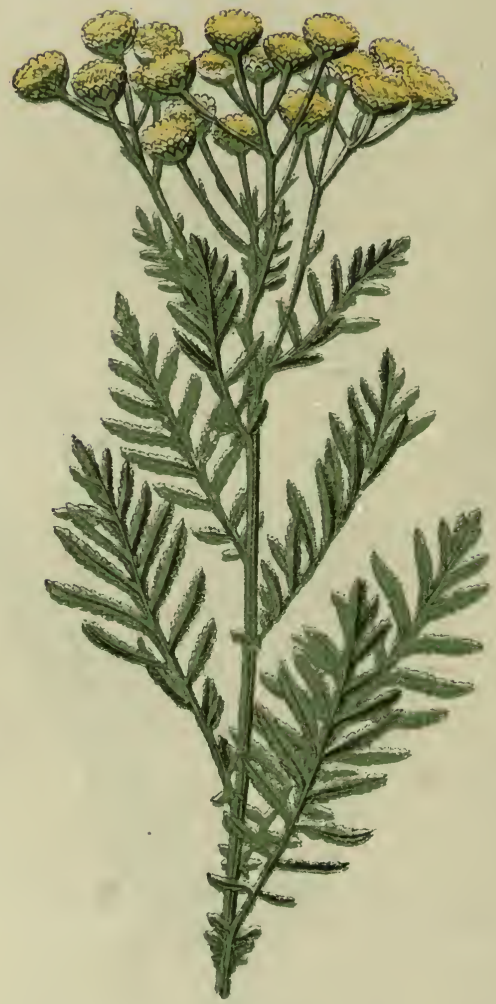

Tansy.

Tanacetum vulgare.

- Composite. - 


\section{Common Tansy (Trnacetum vulgare).}

Time was when every cottage garden and every kitchen garden had its clump of Tansy, for it was a valued item in the housewife's pharmacopœia, and was all but invaluable in cookery. A belief is entertained by some botanists that the Tansy-plants growing wild in waste places by field and roadside throughout the country are garden escapes, or their descendants, that have become naturalized.

The Tansy is a perennial, with creeping rootstock, from which arise beautiful broad feathery radical leaves and flowering stems. The leaves are very deeply divided in a pinnate or bi-pinnate manner, the segments toothed. The angled stem reaches a height of about two feet, and then branches off into a corymb of flower-heads. Each flower-head is enclosed in a half-rounded involucre of leathery bracts. There is an outer row of ray-florets, but they are very short, and of the same dull yellow colour as the disk-florets; they are pistillate only, whilst the disk-florets are all staninate. Flowers during August and September.

All parts of the plant give off a strong aromatic scent when touched or handled, and the taste is exceedingly bitter, a quality which caused it to be used as a stomachic tonic and a vermifuge.

This is the only British species of the genus, whose name is said to be a corruption of Athanasia deathless; but probably it is not so derived. 


\section{Blackthorn, or Sloe (Prunus communis).}

It seems quite natural to use the two common names of this beautiful shrub at different times. In the spring, before a leat has unrolled upon the spine-tipped spurs of its soot-coloured branches, we call it the Blackthorn, for by contrast with its pure white stars its thorns are black indeed. In the autumn, when we search the common, the copse-side and the thick hedgerow for ripe bramble fruit, we only know it as the Sloe. Then the plant is again in full beauty with its groups of round plums, each finely coated with the purple bloom that is ruined by a touch. Like the Whitethorn (page 17) and the Bramble (plate 30), the Blackthorn is a rose, with the floral organs in fives. The fruit is botanically a drupe: it is the result of a swelling up of the ovary, the outer walls of which become succulent and pulpy, the inner hardened into the "stone" inclosing the "kernel" or seed. The leaves are small, elliptical, finely toothed, and in a young state the underside is downy, but in the adult condition smooth. All the branches are spiny.

There are two forms with brown bark which have been at various times regarded as separate species, or as mere varieties, but which Sir J. D. Hooker ranks as sub-species, marking a stage in which varietal characters have become permanent, but not sufficiently strong to hide their connection with the parent form. These are :-

I. The Bullace ' $P$. insititia), with larger and broader leaves, underside downy in the adult condition; branches straight, only a few with spines; the petals broader ; the fruit more drooping, black or yellow, larger, and less rough to the taste.

II. Wild Plum ( $P$. domestica). Branches straight without spines. Fruit larger, black. Leaves downy on the ribs of the underside. The plums of the fruiterer and the "prunes" of the grocer are cultivated forms of this species.

They all flower in March and April. The name is the old Latin appellation for the fruit. 
$-109-$

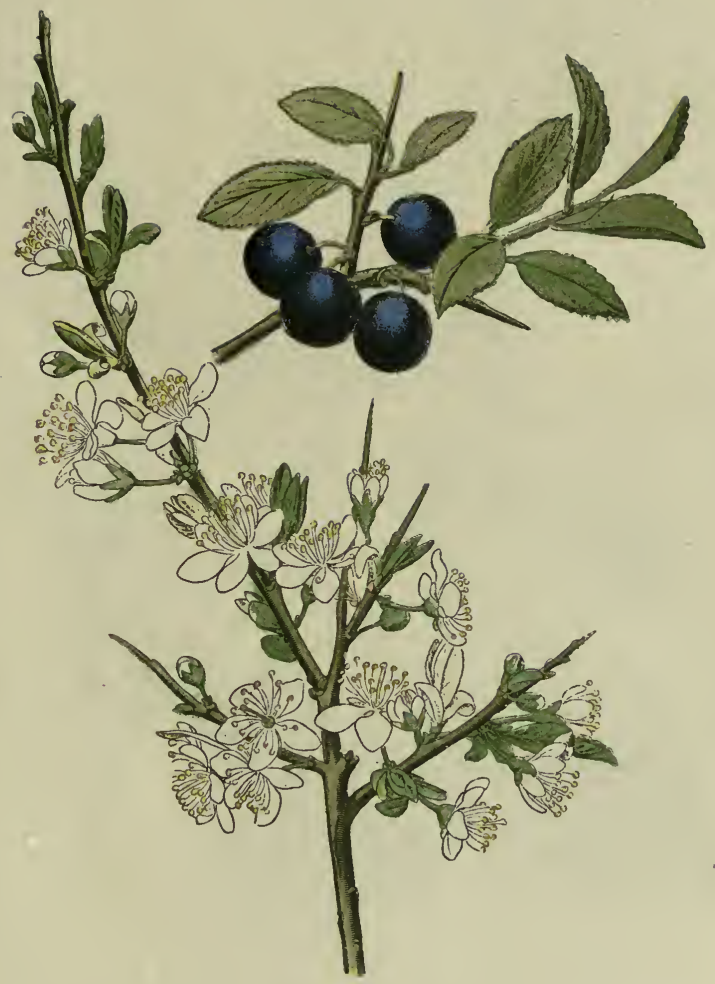

Sloe. Blackthorn.

Prunus communis.

- ROSACEA, - 


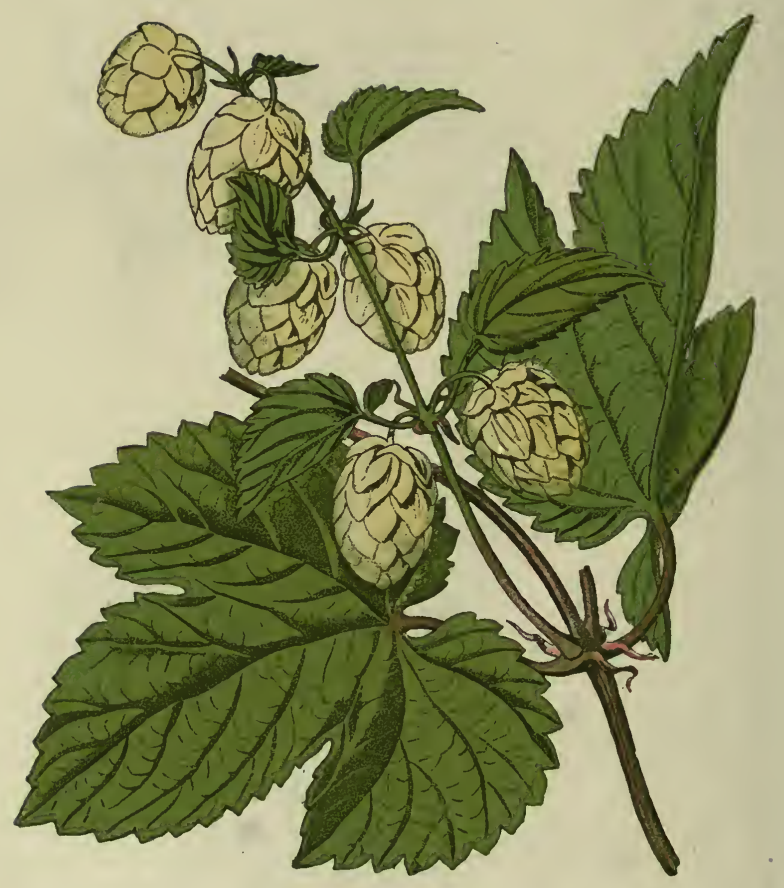

Wild Hop.

Humulus Iupulus.

- URticacex. - 


\section{Wild Hop (Humulus lupulus).}

The Wild Hop may not unfrequently be seen in the copse and hedgerow, especially in the South of England. It has a thick branching perennial rootstock-in the cultivated plant called a."set"-from which are produced several long, thin, but tough twining stems that turn with the sun, and tightly clasp the nearest small tree or shrub. It has no tendrils like the vine, but climbs like the convolvulus by simply twining with the sun as it grows. Its lobed and coarsely toothed leaves are very similar to those of the grape-vine, but very rough. The leaves are in pairs, and at the base of the leafstalk is a pair of long curved stipules. The Hop is what botanists term a dicecious plant, because staminate flowers only are produced by one individual, and pistillate only by another, making cross-fertilization imperative. It is not the insects, however, that effect this crossing in the Hop, but the wind. The flowers are all small; the staminate produced from the axils of the leaves in long drooping panicles. They have no petals, but there are five sepals and five anthers attached to their bases. Each pistillate Hower has a membranous sepal, an ovary, and two long tapering purple stigmas. Two of these pistillate flowers are produced in the axil of a green, broad, concave bract or scale. A number of these twin-flowered bracts are united into a dense spike, and after fertilization this develops into a large cone-like head of yellow scales with resinous glands at their base, which yield a resinous substance called lupuline. The true fruit is a little nut, which is enclosed in the sepal under the bracts. It flowers in July and August. It is the only British species. Beside their extensive use in brewing, the flowers are frequently used to stuff pillows, their narcotic odour inducing sleep. 


\section{The Salad Burnet (Poterium sanguisorba).}

When "cool tankards" were more generally compounded than they are to-day, Salad Burnet was a better-known plant, for, like Borage, it formed one of the ingredients. It was used also in the salad bowl, its leaves having a flavour very similar to that of cucumber. It is a perennial, the rosette of radical leaves springing from a stout rootstock. The leaves are all pinnate ; the leaflets in pairs, coarsely toothed, and a terminal leaflet. The stems are slender, branched, and the flowers are gathered into a purplish head. They have no petals, and are of two kinds : the upper ones have a four-lobed calyx with a narrow mouth, from which two styles with brush-like stigmas are exserted; the lower bear both stamens and stigmas, or stamens only. The stamens are four in number, attached to the mouth of the calyx, and the anthers hang out. The plant may be found abundantly in dry pastures, especially in a chalk district, flowering from June till August.

The Rough Burnet ( $P$. muricatum), found in cultivated fields in the Midlands and South of England, is probably only a variety of sanguisorba, owing its large size and roughness to the richer soil it finds in the fields.

The Great Burnet ( $P$. officinale), was formerly regarded as constituting a separate genus, Sanguisorba, but it is very similar to the Salad Burnet. Its flowers, however, are all alike, and contain both stamens and pistils. It is much larger than Salad Burnet, and its flower-heads more cylindric, longer, and of a darker purple hue. The stamens, too, instead of hanging far outside the calyx, are no longer than the lobes of that organ. The flowers produce honey, and are fertilized by insects. The leaflets are fewer and longer in this species. Its habitat is damp meadows, and its flowering time the same as Salad Burnet.

The name Poterium is the Latin term for a drinking-cup, in allusion to its use indicated above. 


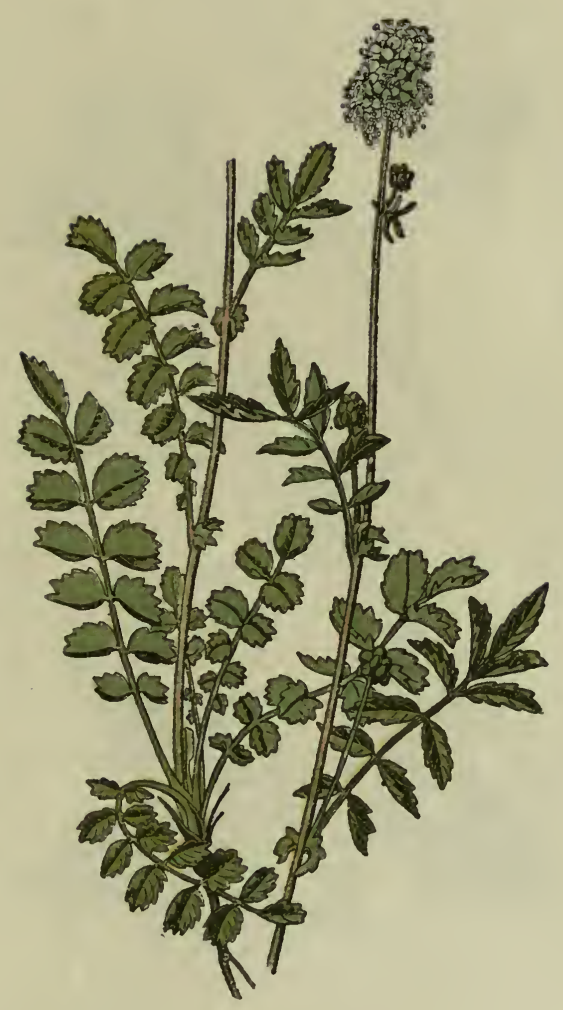

Salad Burnet.

Poterium sanguisorba.

- ROSACEA. - 
$-112-$

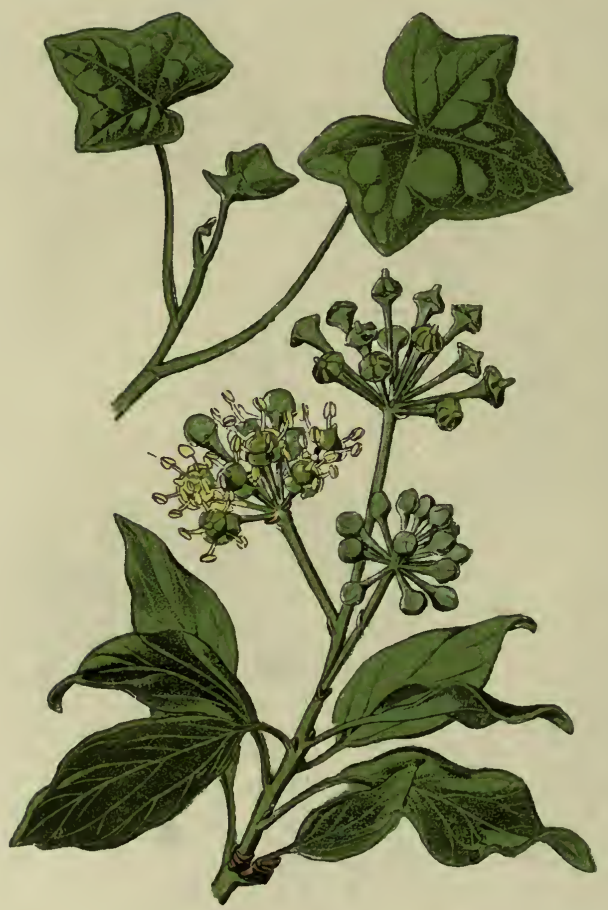

Ivy.

Hedera helix.

- ARAliaces. - 


\section{Ivy (Hedera helix).}

How common is Ivy, whether wild or cultivated! Yet how few are acquainted with its flowers!

There is no occasion to say that the Ivy is an evergreen perennial climbing shrub, nor to describe the form of the beautiful leathery leaf. If there is one leaf that may be said to be thoroughly well known to every British man, woman, and child, it must be the Ivy, for it thrives in dark corners of towns as well as on the hedge-banks of the country, and its foliage has been so well used in all classes of ornamental work. And yet there are few leaves that are subject to such great variation of form, though, with all its changes, one dominant character runs through them all, except its upper leaves, which are totally unlike. The Holly has prickly leaves for its lower branches, but those that are above the heads of browsing cattle have "entire" margins. So with the Ivy ; its five-lobed leaves are for its trailing and climbing branches, but when it has reached the top of the wall or the tree it puts on simple lance-shaped leaves, and in September or October crowns these shoots with its umbels of yellow-green flowers.

The flower consists of a calyx with five triangular teeth, petals and stamens five each, style one, with five obscure stigmas. The flowers are succeeded by blackish berries, sometimes yellow. There is a common woodland variety, with smaller, narrower leaves, that never flowers ; neither do those forms that persistently trail along the hedge bottom instead of climbing. Ivy has been at various times condemned as causing dampness in the walls it covers; the exact converse is the truth. It is the only British species; the genus contains but two for the whole world. 


\section{Arrowhead (Sagittaria sagittifolia).}

One of the most striking among the many forms of leaves that go to make up the vegetation of the sluggish stream or the canal is the aptly-named plant here figured.

It is a perennial, the leaves are radical, and from the base of the plant runners are thrown out, each ultimately terminating in a globose tuber. The leaves are typical of what botanists describe as a "sagittate" leaf, and their long stalks are threeedged. The stem is leafless, but bears a number of flowers in series of threes. These flowers are of two kinds, staminate and pistillate, and because, like those of Poterium, they are borne upon the same plant, botanists describe Sagittaria as moncecious, just as they describe the Hop as dicecious, because its two sexes are on different plants. There are three sepals, and three large white petals with purplish spots at their base. The lower flowers contain carpels only, which are many in number, and which develop into a compact head of nut-like fruits. The stalks of these pistillate flowers are shorter than those of the staminate flowers above them, which contain purple anthers. It flowers from July to September, and is frequent in England as far north as Cumberland, as an indigenous plant; in Scotland it has become naturalized, and in Ireland it is of local occurrence. It is the only British species.

The name is from the Latin sagitta, an arrow. 

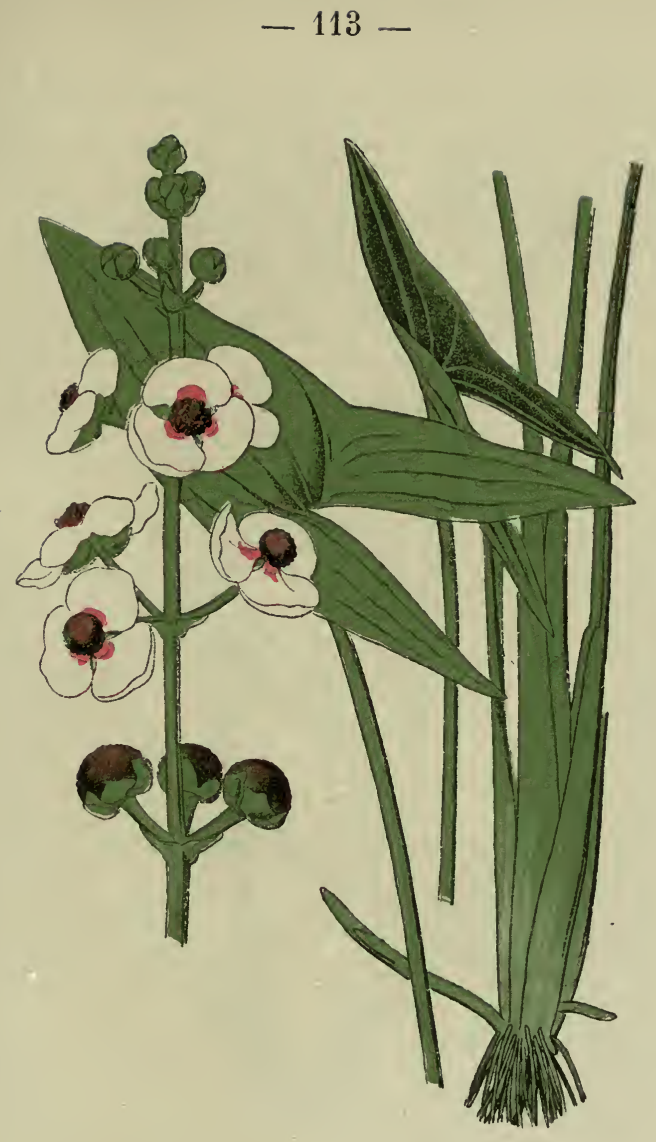

Arrowhead.

Sagittaria sagittifolia.

- Alismacez. - 


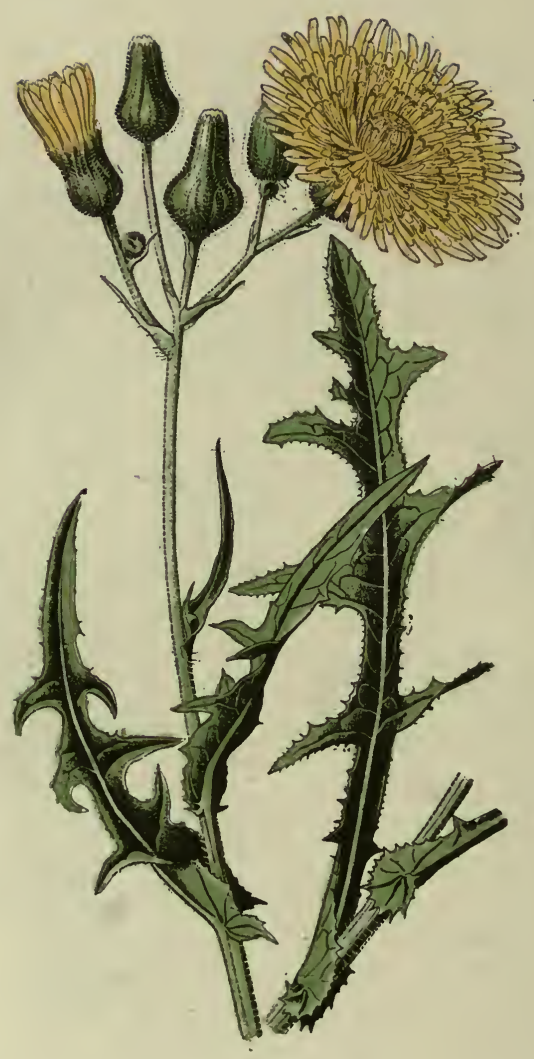

Sow - thistle.

Sonchus arvensis. 


\section{The Corn Sow-thistle (Sonchus arvensis).}

We were nearly remarking that the Sow-thistle is one of the most beautiful of our native flowers, but remembering that we have already applied that observation to several species, we will alter the formula and say it is among the most handsome. Certainly no one who sees it growing is likely to pass it by without plucking some of the flowers, though they will be disappointed in these flagging and losing their beauty before home is reached. We have three native species, of which this is undoubtedly the finest, the stem growing to a height of three or four (or, as we have found it in Surrey, over five) feet. It is a perennial, with a large creeping rootstock, which sends off runners. The stem is hollow, milky, and clasped by the bases of the finely cut leaves. These are deeply lobed, and edged with sharp teeth; the lower leaves have stalks, the upper have not. The unopened involucre-for this again is a Composite-will strike the finder as being singularly square ; it is covered all over-as are the stems also-with short hairs with glandular tops of a golden yellow. The expanded flower-head is about two inches across, and is composed entirely of rayflorets. The plant will be found flowering in or around cultivated fields in August and September. The other British species are :-

I. Marsh Sow-thistle (S. palustris), now all but extinct, and found only rarely in the Eastern counties of England and Kent. It is taller-growing than arvensis, the stem sometimes reaching nine feet, but the flowers are only half the size of that species.

II Common Sow-thistle (S. oleraceus). A common annual in every field and waste. General character of plant very similar to arvensis, but smaller. Stem, two to three feet in height, without (or rarely with) the glandular hairs. Flowerheads many, not exceeding an inch in diameter. June to September.

Name supposed to be derived from the Greek, sonthos, hollow, in reference to the fistular stems. 


\section{Grass of Parnassus (Purnassia palustris).}

It is a singular thing that some of our most beautiful plants grow in the most unpleasant places. We remember a backwater of the River Thames that used to receive the waste waters from a large soap-works, and in the evening, when this waste was poured out, the stench arising from the ditch was unbearable. Yet, with its feet in this vile liquid, the Meadowsweet grew luxuriantly, but truth compels us to add that its sweetness was thrown away; it could not overcome the other smell. Black bogs and mossy swamps are the particular haunts of floral beauties, such as the marsh violet, the bog buckbean, the marsh marigold, the bog pimpernel, the sundew, the bog asphodel ; and it is in such resorts we must look for the Grass of Parnassus, a plant so pretty and elegant of form that it must first have grown upon Mount Parnassus. At any rate, the English name is a mere translation of that given to it by Dioscorides, among the six or seven hundred plants mentioned by him.

It is a perennial, with a stout rootstock. With few exceptions the leaves are radical; they are heart-shaped, smooth, with untoothed edges, and on long stalks. The flowering stems are long, angular, with a stalkless leaf nearly half-way up. At the summit is the solitary large flower. The fine thick sepals are slightly conjoined at their bases, the petals white, veined and leathery. The ovary is large, and on its summit, without the intervention of a style, are the four rayed stigmas. Around the ovary are five stamens-there should be ten, but five have been transformed into scales, which alternate with the perfect stamens, and are fringed with white hairs, each ending in a yellow knob; on the face nearest the ovary each scale bears two small honey-secreting glands. The perfect stamens ripen in succession, and as each becomes mature, it raises itself until the anther comes on top of the stigma, but with its back to it. 
$-115-$

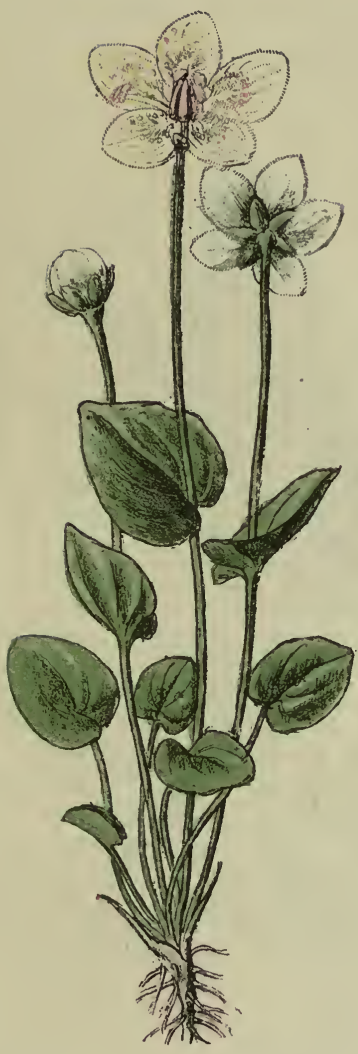

Grass of Parnassus.

Parnassia palustris.

- Saxifrage. - 
$-116-$

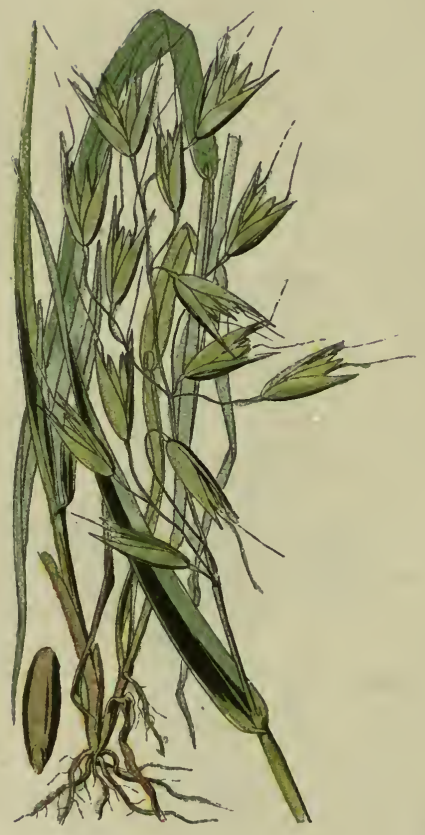

Oat.

Avena sativa.

- Gramineж. - 
The front opens and discharges the pollen away from the stigma; but it falls where insects seeking the honeyed glands (using the ovary as a perch) will get it upon their forelegs, and so attach it to the stigmas of the next flower they visit.

It flowers in August and September. This is the only British species.

\section{Oat-grass (Avena sativa).}

We have three British species of Wild Oat, but a knowiedge of their structure and differences may be best obtained perhaps by a consideration of the cultivated Oat of our fields. It is indeed probable that the cereal oat is but a cultivated form of our Common Wild Oat (A. fatua), for Professor Buckman succeeded years ago in obtaining as the ninth generation from seeds of $A$. fatua good crops of the farmers' varieties called White Tartarian and Potato Oats. It is known that oats shed in harvesting often degenerate into the wild forms. As a cereal the Oat does not appear to be nearly so ancient as wheat and barley, for it was not cultivated by the Hebrews, the Egyptians, Greeks or Romans.

The genus is distinguished by having its flowers in a laxpanicle, the spikelets borne principally upon long, slender stalks. Each spikelet contains two or more flowers, of which the upper one is usually imperfect, and each is armed with a long twisted and bent awn. 'There are two outer glumes, each flowering glume deeply notched, the awn arising from the bottom of the notch. The pale is two-nerved, the scales twotoothed, the stamens three. The ovary has a hairy top and two short styles with feathery stigmas. The fruit adheres to the glume.

I. Wild Oat (Avera fatuc). An annual with two- or three-flowered spikelets which droop at length. The empty glumes with nine nerves, flowering glumes covered with stiff hairs. Brown awn much bent, the lower half twisted. Leaves flat and roughish; sheaths smooth. Cornfields. June to August.

II. Narrow-leaved Oat (A.pratensis). Perennial; not to be sought in the place 
indicated by pratensis, as it is a plant of the moor and dry pasture. Spikelets half erect, six flowered. Leaves flat, or edges rolled inwards, smooth, hard and rigid. Lower sheaths rough. Flowering glume, rough. Awn only slightly bent. June and July.

III. Downy Oat (A. pubescens). Perennial. Spikelets half erect, two-flowered. Leaves flatter than $A$. pratensis, downy; sheaths very downy. Awns wider apart. Dry pastures. June and July.

The name is the old Latin term for oats and reeds.

\section{Mountain Ash or Rowan (Pyrus aucuparia).}

We have considered many members of the beautiful Rose family already, but we have now a representative of another branch of it-the Wild-Apple section. The fruit of the Mountain Ash is really a little apple. It has no relationship with the Ash (Fraxinus, see page 135), but the mere resemblance of its pinnate leaves has won the name. It is a low tree, growing from twenty to forty feet in height. It flowers in May, the creamy white blossoms being grouped in a cyme. The leaf is divided pinnately into six, seven, or eight pairs of leaflets and a terminal odd one ; each leaflet toothed, the mid-rib and nerves hairy. The calyx also is hairy. The flowers are succeeded by a cluster of bright scarlet tiny apples, with yellow flesh and a three-celled hard "core" or endocarp. These are ripe in September, and are eagerly sought after by birds-a fact of which advantage has been taken by bird-catchers of all times and places where the tree grows. It is used for the purpose of baiting their horse-hair springes, whence it has got the name of Fowler's Service-tree, and in the principal European countries it bears a name of like import. Its folk-names in this country alone make a long list :-Quicken-tree, Quick-Beam, Wiggen, Whichen, or Witcher, Wild Ash, Wild Service, Rowan, Roan, or Roddan, Mountain Service, and other variations. Some of these names are reminders of its supposed protective powers against the machinations of witches and warlocks. "Witches have no power where there is Rowan-tree wood."

Pyrus is the old Latin name for a pear-tree. 

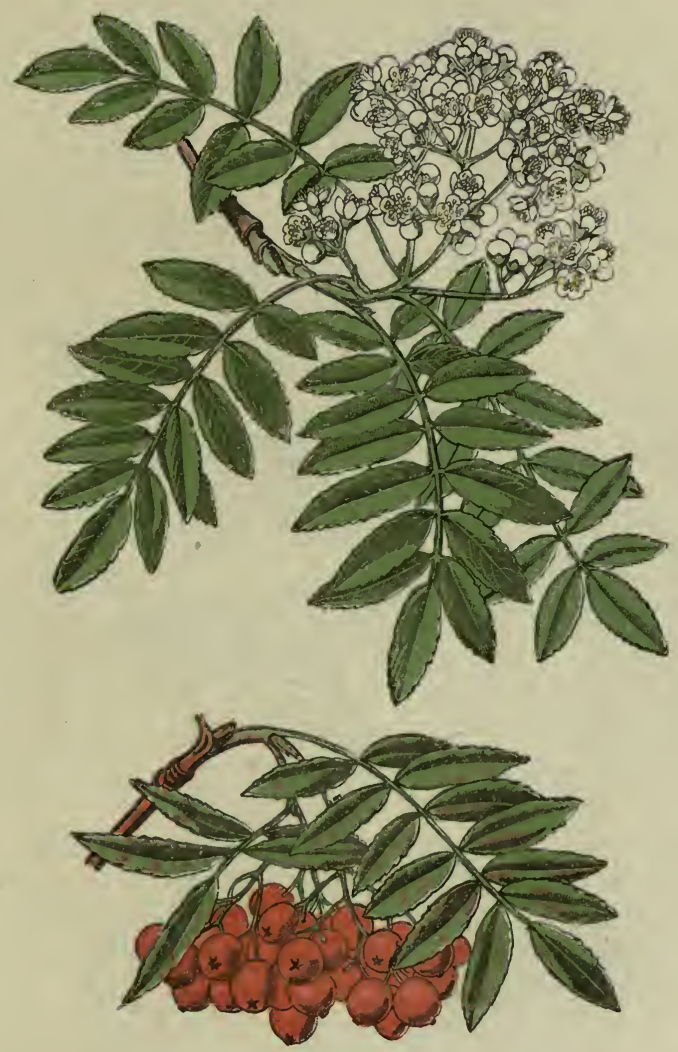

Mountain Ash. Rowan-tree. Pyrus aucuparia. 


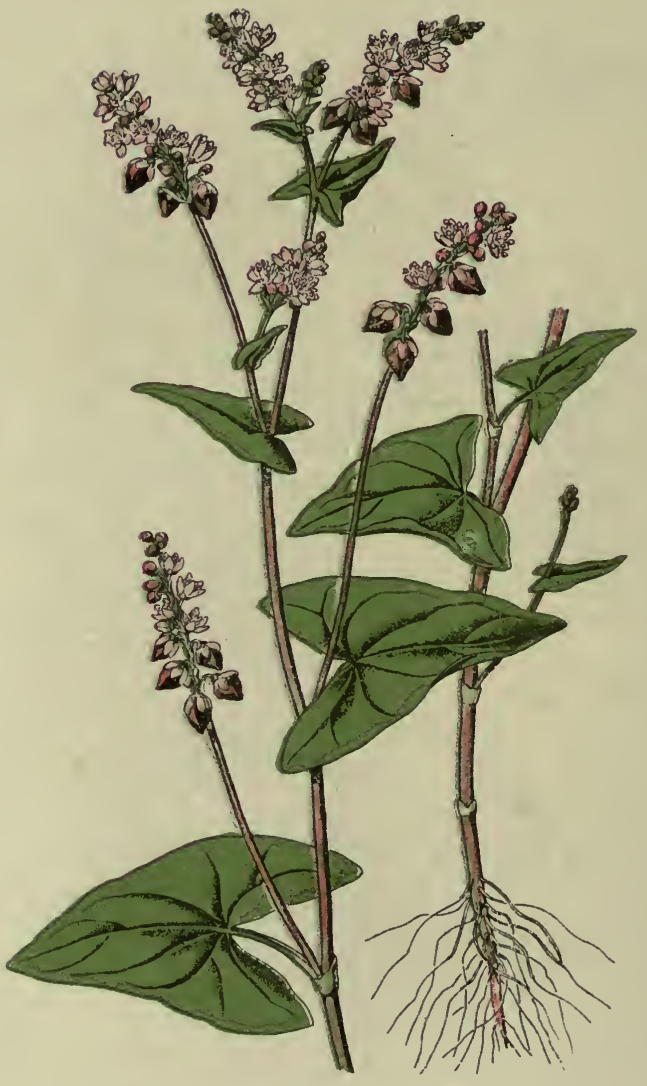

Buckwheat.

Polygonum fagopyrum.

- POLygonefe. 


\section{Buckwheat (Polygonum fagopyrum).}

In the neighbourhood of manure-heaps and on the borders of cultivated ground one may come across this plant, which was formerly included in the British Flora, but is now known to be a mere waif of cultivation. Its home is in Central Asia, but it has been so long cultivated as a food-plant in Europe and in the United States that it has become naturalized in most places. In this country it is chiefly grown as a food for pheasants. It is an annual, with a tall, slender, branched, reddish stem, and heart-shaped, almost arrow-headed leaves with entire margins. Flowers in panicles. The individual blossoms consist of five pale reddish sepals, no petals, eight stamens, and three styles. The flowers are of two forms, one with long stamens and short styles; the other with short stamens and long styles. The fruit is large, three-sided, solitary in a nut, very like beechmast, whence its folk-name buch- or buck-wheat. It will be noted that at the base of the leaf-stalk is a pair of thin stipules, which sheathe the stem and mark the swollen nodes that give the knotted appearance so characteristic of the genus, and which has given it the name of many knees or joints (Greek polus and gonu). Buckwheat flowers during July and August. It is a valuable honey-plant, esteemed of bee-masters. There are a dozen British species; among them:-

I. Bistort or Snake-root (P. bistorta). Perennial, with large twisted rootstock, Radical leaves long, egg-shaped, the upper part of the leaf-stalk winged. Stemleaves almost stalkless, broader near the stem. Flowers pink or white, producing honey ; moist meadows. June to September.

II. Amphibious Buckwheat ( $P$. amphibium). Perennial, rootstock sometimes creeping in the ground, at others floating in the water. If the plant is floating the leaves have long stalks; if growing on land they are almost stalkless. Stipules tubular, large, smoxth in water, bristly on land. Stamens five, styles two. Flowers, rosy-red. July and August ; margins of pools and in other wet places.

III. Spotted Knotweed ( $P$. persicaria). Annual. Stem erect; leaves long, narrowly lance-shaped, with a black heart-shaped patch in the centre, downy beneath; the stıpules fringed with a few long hairs. Flowers flesh-coloured; stamens six, styles two. July to October, in moist places. 
IV. Kuotgrass ( $P$. aviculare). Annual. Stems branching from the root, very slender and straggling, smooth. The leaves small and grassy, stipules small, white, torn-looking, red at the base. Flowers very small in the axils, pink. Stamens eight, styles three. Waste places and neglected gardens. May till October. The seeds are much esteemed by birds, and to the entomologist the fresh plant is invaluable as an almost universal food for the caterpillars of geometers.

V. Black Bindweed ( $P$. convolvulus). Annual, with twining stems. The leaves are very similar to those of the true Convolvulus, the lobes more pointed ; stipules short. Sepals green, with paler margins. Fields and wastes. July to September.

\section{Fool's Parsley (AEthusa cynapium).}

Fool's Parsley is fond of cultivated ground, and it is no unusual thing for it to make its appearance in the very garden beds that have been set apart for rearing that pot-herb for which fools are said to mistake it. It is an annual, with a spindleshaped, fleshy root, round, hollow stem, branched, and marked with fine longitudinal lines. The leaves are smooth, compound, and bluish green in tint. The wedge-shaped leaflets are themselves pinnate, and the pinnæ are lobed. The flowers are small and irregular, white, grouped in small umbels, which are again gathered into large umbels of umbels.

The reader is invited to turn back to page 55, where the structure of umbelliferous flowers and fruits is more intimately described. The small umbels in $A$ thus $a$ are provided with an involucre consisting of three or five little bracts, very narrow and hanging vertically. This feature will serve to distinguish $\not E t h u s a$ from all other umbellifers. The entire plant is evil-smelling, and said to be poisonous. It flowers during July and August, and is the only species. It gets its generic name from the Greek aitho, to burn, from its acrid character, and its specific name is a combination of Kynos, dog, and apion, parsley, which is a further note of its worthless character. 


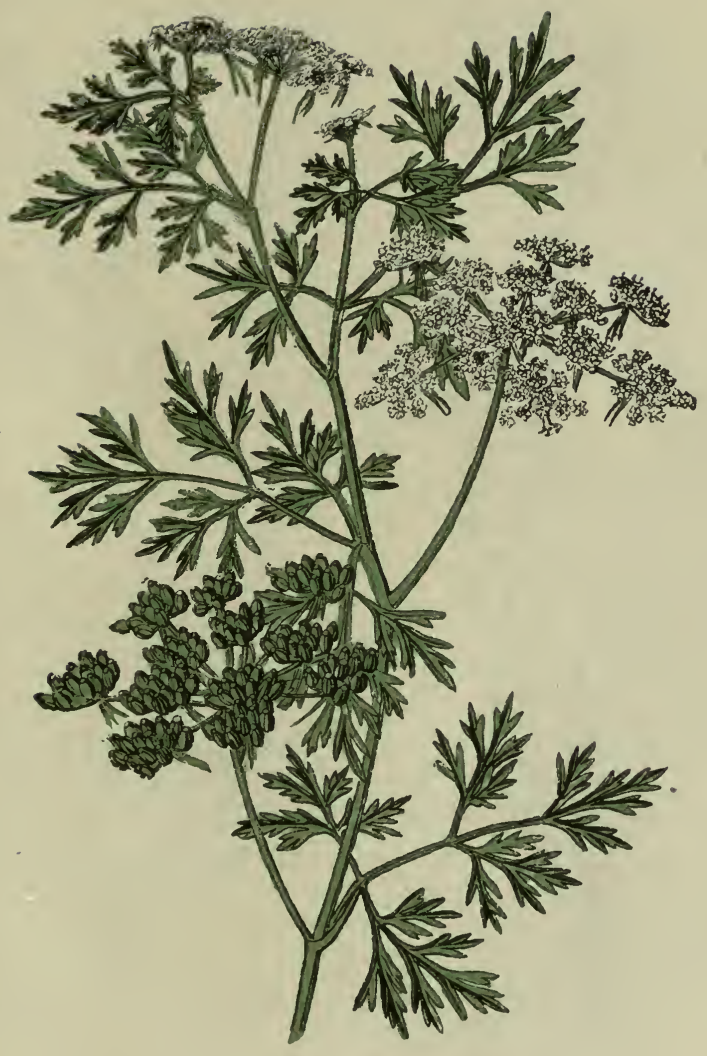

Fool's Parsley.

Ethusa cynapium.

- UMBellifer A. - 


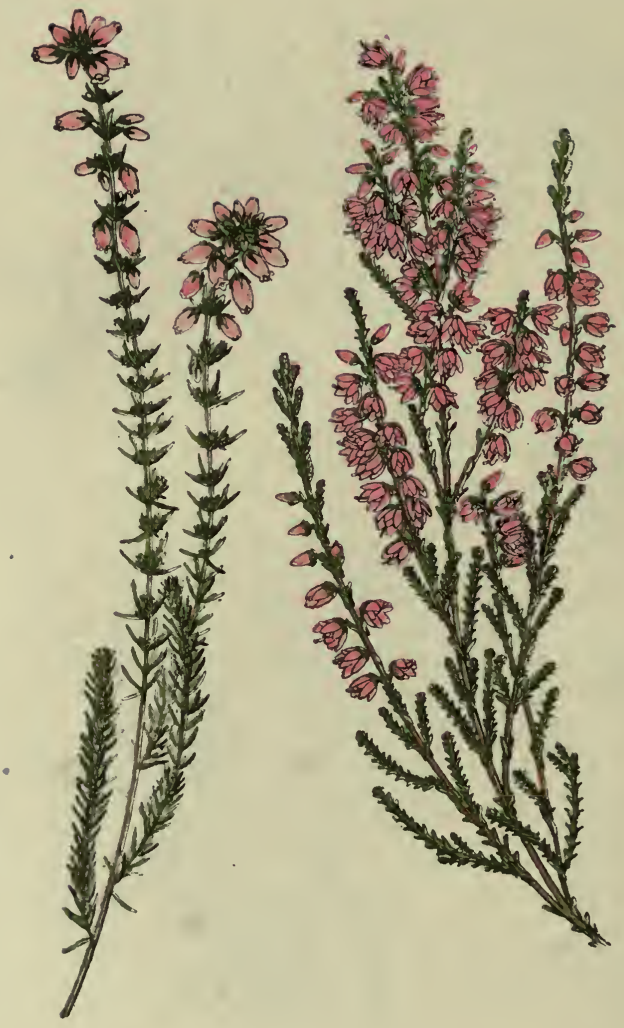

Fine-leaved Heath.

Heather-Ling.

Erica cinerea.

Calluna vulgaris. 


\section{Fine-leaxed Heath (Erica cinerea).}

This is the common Purple Heath of our elevated heaths and commons, distinguished from its relatives by its smooth stems and leaves; the latter exceedingly narrow, their edges curled under, and arranged around the stems in whorls of three leaves, with clusters of minute leaves in their axils. The flowers also are in whorls, and either horizontal or drooping. The sepals are four in number, green; the corolla in one, egg-shaped, with four short lobes around the mouth. The stamens are eight, bearing two-celled crested anthers, each cell opening at the side to discharge its pollen, and having a toothed process at its base ; the cell-openings of one anther being pressed against those of neighbouring anthers. The style is dilated at the top, and its surface is the stigma. Flowers July to September.

\section{Another common species is}

The Cross-leaved Heath ( $E$. tetralix), with downy stems and leaves; the leaves in whorls of four, and fringed with hairs, margins rolled under as in cinerea. Flowers pale-rosy, drooping, gathered into a dense head at the summit of the stem. The corollas are pale, almost white, on their under-sides. The anthers like those of cinerea, but with two longer processes from the base of each. Bees visit the Heath plants for their plentiful honey, and in pushing their long tongues into the flower in search of it touch their heads against the stigma, which partially blocks the mouth of the corolla. The tongue has to press against one or more of the anther processes, which has the effect of dislocating the series of anther-cells, and allowing the pollen to fall through the opening upon the bee's head, which is thus ready to fertilize the next flower it visits. This species may be found growing with $E$. cinerea, but usually selects the dampest, boggy spots on the heath. Flowers July to September.

There are two other species, $E$. vagans and $E$. ciliaris, but they are confined almost entirely to the county of Cornwall; the former distinguished by its bellshaped, not egg-shaped, corolla, and anthers and pistil hanging outside; ciliaris marked by its leaves being fringed with hairs, each hair tipped with a gland.

The name is from Ereikh, the ancient Greek name for heath or heather. 


\section{Heather or Ling (Calluna vulgaris).}

The Ling is distinguished from the Heaths by the botanist because its bell-shaped corolla is concealed by the longer, equally coloured calyx leaves, and below these are four bracts which resemble a calyx. Its leaves are triangular, very minute and densely packed, overlapping each other. Like the Heaths its flowers are persistent, and are to be found bleached but preserving much of their original form, nine or ten months after they opened. The anthers are short, and contained within the corolla, but the style is long, and protrudes. The tough wiry stems attain considerable size in the highlands of Scotland, where they serve many useful purposes. It flowers from July till September. C. vulgaris is the only species. The genus gets its name from the Greek Kalluno, to beautify or adorn, an epithet which all who have visited the moorlands in its flowering season will admit is well-bestowed.

\section{Mistleto (Viscum album).}

Is there a person in these islands above the age of infancy who does not know the Mistleto by sight? Why, then, let it occupy space here? Because it is one of those very wellknown things that we only partially know. What percentage of those who took advantage last Yule-tide of the mystic sanctions of the plant, and who consequently think they know it so well, have seen its flowers? or know that it has flowers? True, those of our British Mistleto are not very striking in point of size or showiness ; but there are tropical species with flowers both large and brilliant.

In $V$. album the flowers are of two kinds, male and female, each (with rare exceptions) being borne on separate plants, so that cross-fertilization is imperative. They are both green, and consist of a four-lobed perianth, the male with four anthers 
$-121-$

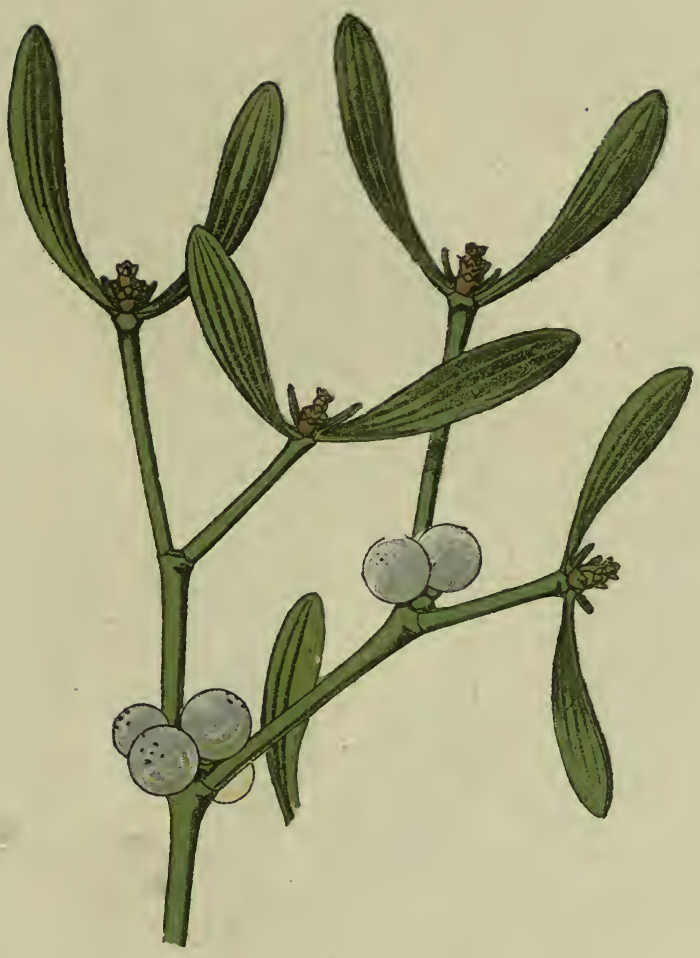

Mistletoe.

Viscum album.

- LORanthaceE. - 
$-122$

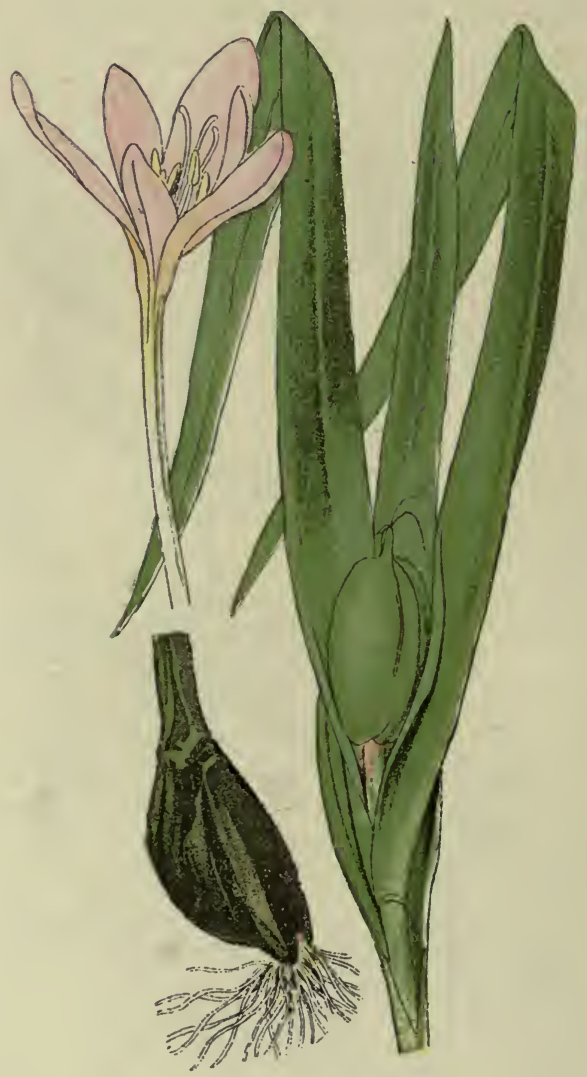

Meadow Saffron.

Colchicum autumnale. 
attached to the perianth, such anthers opening by a large number of pores. The female flower has the perianth adhering to the ovary, to which the stigma is directly attached, there being no style. The ovary, as all know, develops into the globose white berry, containing the large seed with its viscid coat. These occur usually in twos or threes. The flowers may be found any time between March and May.

This leathery parasite is not very particular as to its host. Quite a large number of trees of different species harbour it, notably the apple ; next in favour are poplars, hawthorns, lime, maple, mountain-ash, and very rarely the oak. It has been suggested that the very fact of its extreme rarity upon oak gave oak-grown mistleto its sacred character among the ancient Britons.

\section{Meadow-Saffron (Colchicum autumnale).}

The Meadow-Saffron is more frequently known as the Autumnal Crocus, but we object to the name as conveying a wrong idea of the botanical characters of two distinct genera. Further, there is a true autumnal crocus (Crocus mudiflorns), though its claim to be considered British is open to doubt. Like Crocus, Meadow-Saffron has an underground solid stem $(\mathrm{corm})$, resembling a bulb, and from this arise the flowers in succession from August to October. These flowers are of a pale purplish colour, and consist of a long slender tubular perianth, enlarging at its upper part into a bell-shape, and this portion is divided into six segments, to each of which a stamen is attached (Crocus has but three). The ovary lies deep within the calyx-tube, and from it arise three long threadlike styles, which are bent over near the tip, the inner side of which is the stigma.

The fruit develops during the winter, and by the spring is ripe. Then when the long, flat leaves make their appearance, the flower-stalk lengthens and brings the ripe capsule above 
the ground. Sometimes the flowers mistake the seasons and put in an appearance with the leaves in spring, but they are imperfect, and the perianth is greenish-white.

The name is from Colchis, where it is said to have grown abundantly.

\section{Hart's-tongue Fern (Scolopendrium vulgare).}

Hitherto we have dealt only with flowering plants. In these sexual organs are borne in more or less conspicuous blosscms, and, as the result of fertilization of the ovules by the pollen, seeds are produced which give rise to plants exactly like that which bore them. Ferns produce an enormous number of minute bodies, called spores, which are incapable of developing directly into a plant similar to that by which they were produced; but on germination they give rise to a minute green scale, like a liverwort, upon the under surface of which sexual organs appear, and by the mingling of their cell-contents a true bud is formed, from which a true fern-plant is evolved. There are other important points upon which ferns differ from flowering plants, but it is not within the author's province to deal with them here. Let it suffice to add that as a fruitbearing organ the leafy portion of a fern differs greatly from the leaves of other plants. To prevent confusion it is termed a frond.

The Hart's-tongue has a frond of very simple characterstrap-shaped-consisting of a stout mid-rib (rachis), with a leathery green expansion on either side, the upper end tapering off to a point, the lower divided into two lobes. A large number of thick red-brown parallel ridges on the under surface will attract immediate attention. These are heaps of delicate capsules (sporangia), which contain the spores. The Hart'stongue is a plant of sandy or rocky hedgerows. 


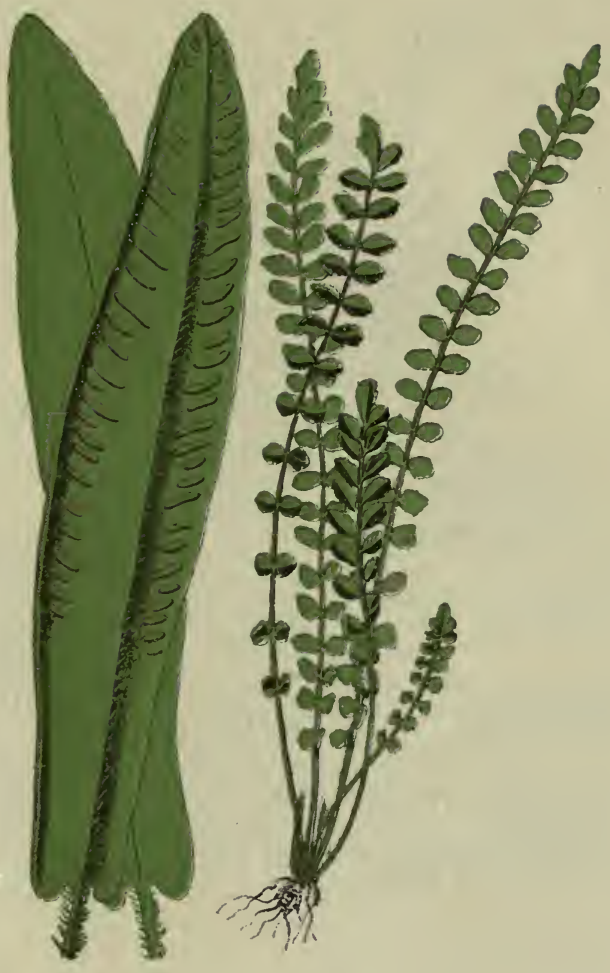

Hart's-tongue Fern. Maidenhair Spleenwort. Scolopendrium officinale. Asplenium Trichomanes. 
$-124-$

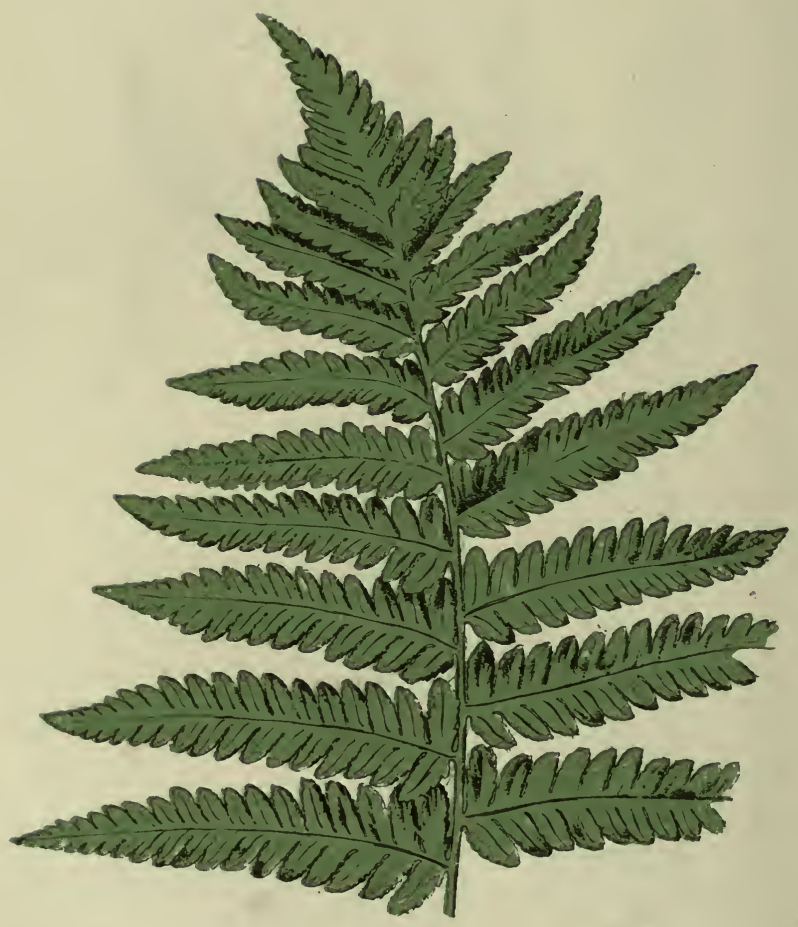

Male Fern.

Nephrodium filix-mas.

- Filices. - 


\section{Maidenhair Spleenwort (Asplenium trichomanes).}

A common plant locally on rocks and walls, having a slender dark-brown polished rachis and a large number of roundishoblong leaflets (pinna), arranged pinnately on each side. The capsules will be found in short thick lines on the under surface. There is a similar species, the Green Spleenwort (A. viride), with a green, softer rachis and the pinnæ distinctly stalked, shorter and paler; growing on wet rocks in mountainous districts.

\section{Male Fern (Nephrodium filix-mas).}

In the Male-fern-so-called by our fathers owing to its robust habit as compared with the tender grace of one they called Lady-fern (Asplenium filix-femina)-we have an advance in the intricacy of frond-division. Our page is not sufficiently large to represent the whole of the frond, but the portion we give shows that the pinnæe are themselves again divided into pinnules. This fern grows to a great size, its rootstock very thick and wcody, its fronds erect and three or four feet high. As a rule the rachis and its continuation below the leafy portion (stipes) are shargy with loose goldenbrown scales. The spore-capsules are in little round heaps in rows along the pinnæ, and each heap is covered by a thin kidneyshaped involucre. Note in the unrolling of a young frond how beautifully the whole is packed up. The lateral divisions of the pinnæ are rolled each on itself, then the pinnæ are rolled up from their tips toward the rachis, and finally the whole frond is coiled up from the tip downwards. This is the characteristic vernation of ferns, and differs greatly from the packing of undeveloped leaves in the leaf-buds of floweringplants. 
The genus Nephrodium (named from nephros, the kidnejs, in allusion to the involucre) contains half-a-dozen other British species, of which the most frequent is the Broad Buckler Fern (N. spinulosum), with arching fronds, broad at the base, the stipes sparingly clothed with dark-brown scales. Pinnules toothed, the teeth ending in long soft points. Damp woods.

Mountain fern ( $N$. oreopteris), with habit of Male fern, but stiffer, and of a yellow-green hue. Spore-heaps near the margins of the pinnæ. High hills and mountain pastures.

\section{Field Horsetail (Equisetum arvense).}

The Horsetails are a small group of flowerless plants, quite distinct from the ferns, though there are certain points in which some resemblance may be traced. We have eight British species out of twenty-five that are known to inhabit the earth. The most widely distributed of these is the Field Horsetail (E. arvense), which farmers regard as a pest. In common with the whole tribe it has a creeping underground rootstock, from which more or less erect jointed stems arise. If we break off one of these joints at its natural articulation we shall observe that the ends are solid, and that the upper extremity is crowned by a sheath ending in long pointed teeth, into which the lower end of the next joint fitted. This leafsheath, as it is called, is composed of a number of aborted leaves - the only vestiges of leaves the plant possesses. Just below the leaf-sheath a whorl of jointed branches is given off, each constructed in a manner similar to the upright stem. If now we cut our main joint across its middle with a sharp knife we shall find that it is tubular, a central cavity occupying about one-third of its diameter. Between this cavity and the exterior wall is a series of small tubes, somewhat egg-shaped in outline, the smaller end towards the central cavity; alternating with these and nearer the centre are a number of smaller circular tubes. This section should always be made when in doubt as to the species, for the shape and arrangement of these cavities differs in each, as do the external 

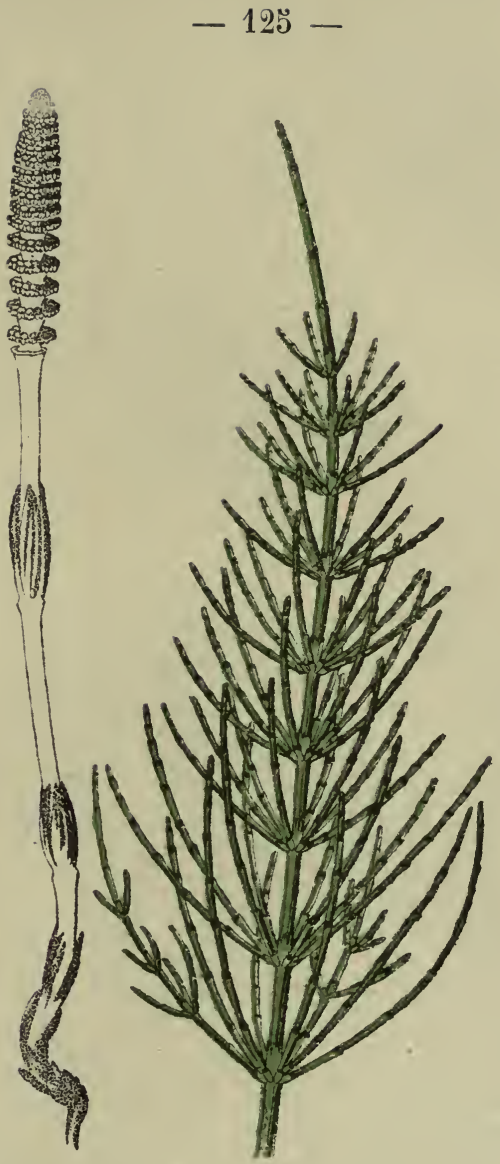

Corn Horsetail.

Equisetum arvense.

- Equisetace 

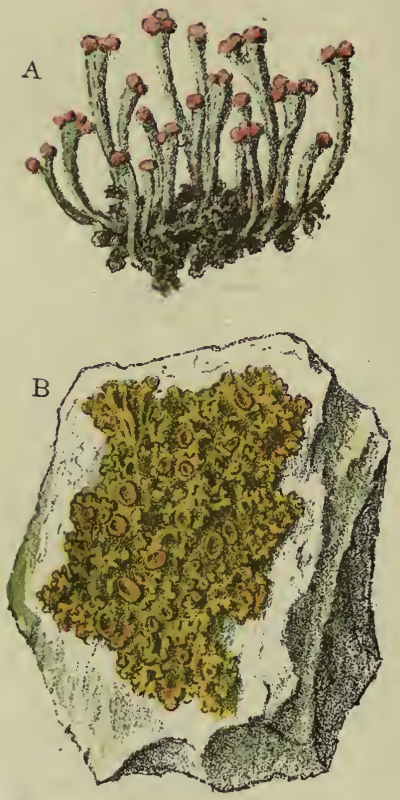

$\Lambda$ - Scarlet Gup-moss.

Cladonia cornucopioides.

B. - Wall-Lichen. Physcia parietina. 
ridges. The accompanying cuts represent half-sections through the stems of the principal British species. In this species there are about a dozen blunt ridges on the stem, extending right to the points of the leaf-sheath. The branches are four-angled, solid, and jointed and sheathed like the main
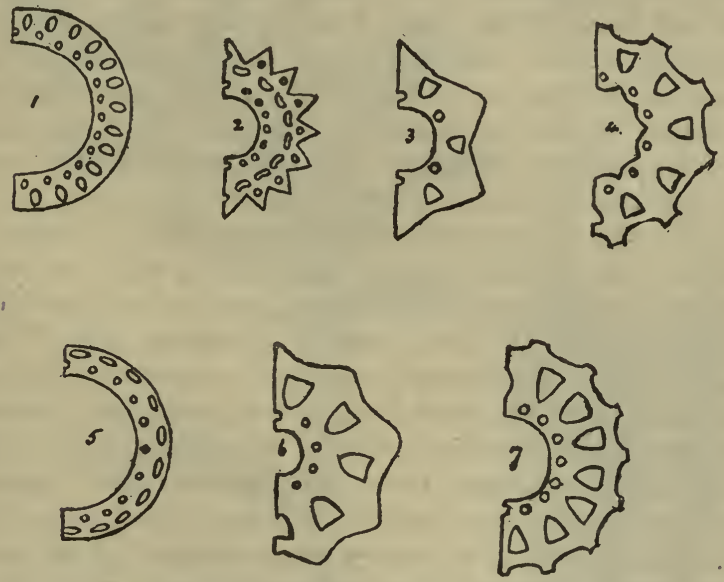

Half-Sections through Horsetail Stems.
I. Equisetum maximum.
4. E. sylvaticum.
2. "
pratense.
5. "limosum.
3. ",
arvense.
6. "palustre.

7. E. hyemale.

stem. The cells of the cuticle secrete silica in such quantity that the whole of the vegetable matter may be got rid of by maceration, yet the form of the stem will remain in this transparent skeleton of silica. Certain species are used for polishing metal, under the name of Dutch Rushes.

So far we have been describing what is known as the barren 
stem, because it ends in several unbranched joints, without any fructification. Before these barren stems appeared there arose from the rootstock a stem differing greatly in appearance, usually without branches, and lacking the green colouring matter (chlorophyll). It is pale brown in colour, of stouter build, but much shorter, for whereas the barren stem is about two feet in length, the fertile is only a few inches, or at most less than a foot. The leaf-sheath is longer, and the teeth frequently adhere two or three together. The stem terminates in a kind of cone, consisting of many whorls of flat scales, each supported by a central stalk, on the underside of which are arranged from six to nine capsules containing spores. These spores are very curious : they are globular in form, and invested with several coats, the outermost of which splits into four narrow strips, which are highly hygroscopic, and which remain attached to the spore at one point only. These elaters, as they are termed, are very sensitive to changes in the humidity of the atmosphere, as may be proved by breathing upon them, however slightly, when they will be seen (through the microscope) to be in active movement. In many ferns the spores require months to elapse before germination takes place; those of Horsetails will germinate in a few hours. Owing to its possession of chlorophyll the spore, if not placed in a situation suitable for germination, perishes in the course of a few days.

The name of the genus is from the Latin, equics, a horse, and seta, a bristle. The fertile stems appear in March and April, the barren ones at intervals later.

\section{Lichens (Lichenes). Plate 126.}

The rambler will meet with specimens of the Lichen tribes at every turn, when he has got fairly away from the smoke of towns. He will find them on the tree-trunks or rocks and 

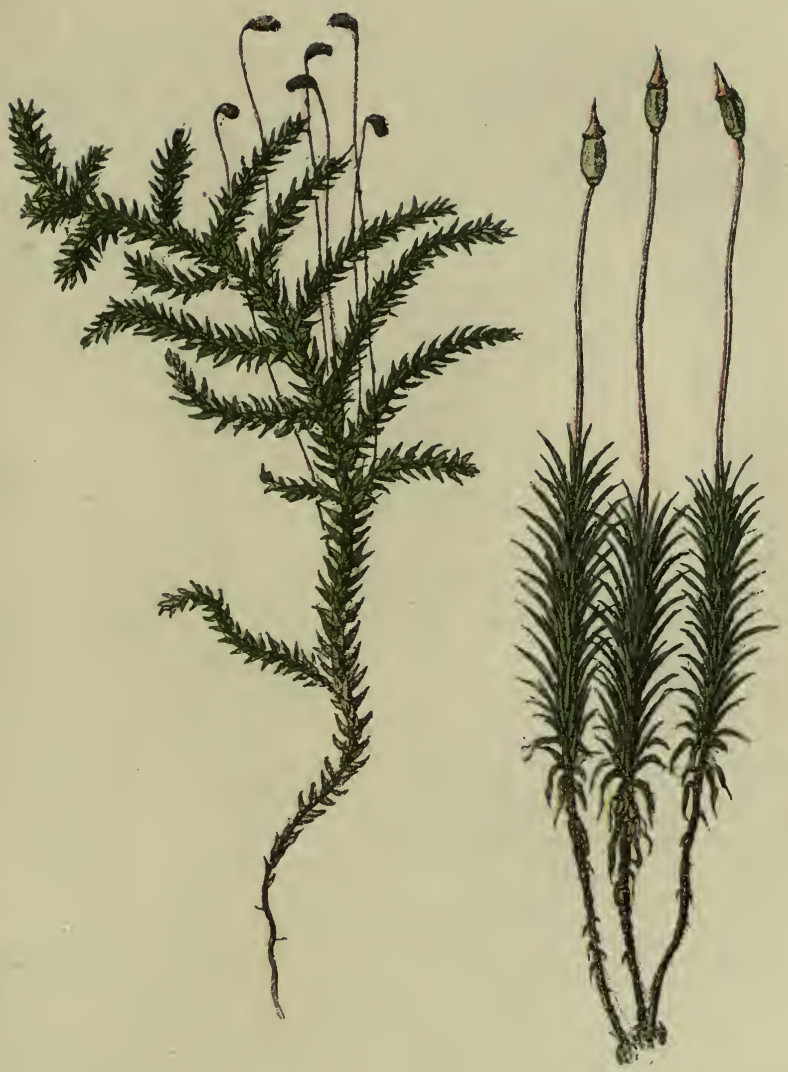

Triangular Moss.

Hair-Moss.

Hypnum triquetrum. 


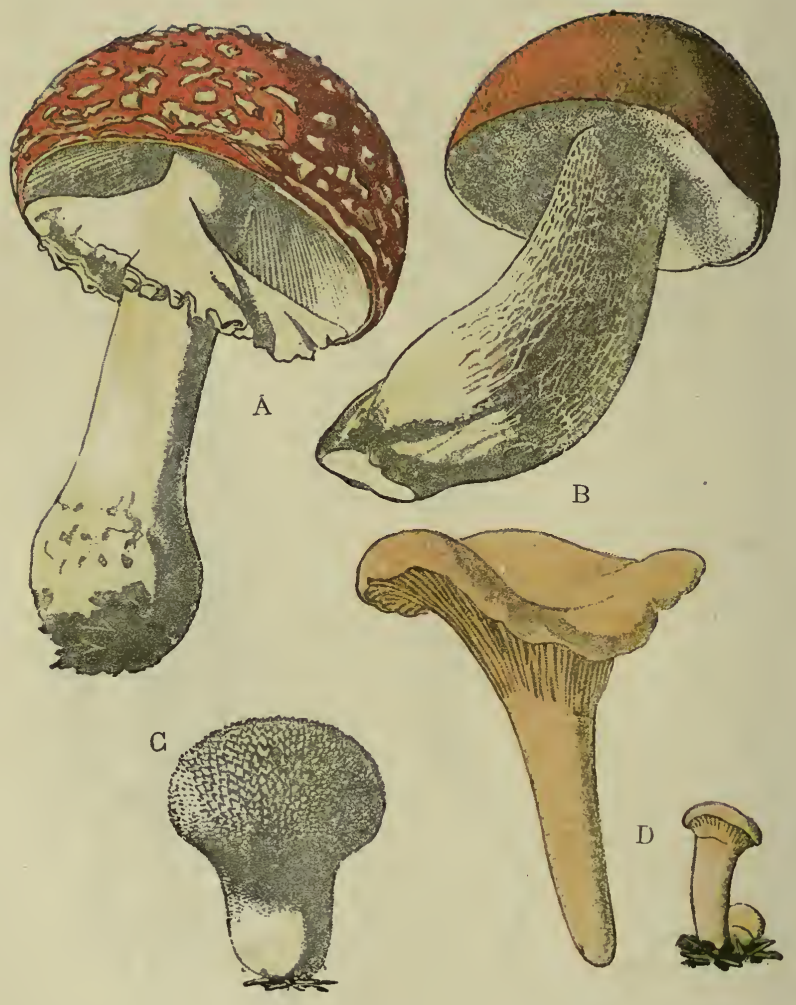

A. - Fly Agaric. Amanita muscarius.

$$
\text { C. - Puff-ball. }
$$

Lycoperdum gemmatum.
B. - Edible Boletus. Boletus edulis.

D. - Chanterelle.

Cantharellus cibarius. 
walls, old posts and palings, on thatch and on the ground. Wherever they are found they may be accepted as certificates of the purity of the air. Formerly considered as a distinct type, they are now held by the advanced school of cryptogamic botanists as commensals, or partnerships formed between a fungus and an alga. They are usually thin crusts, consisting of an upper and a lower epidermis, formed of closely crowded cells, and to the lower layer rootlike filaments are attached. Between these layers are two differing elements; a loose stratum of green cells (gonidic), which are said to be algce, and below these a layer of fungoid threads. The contention of the new school is that these alga have been captured by a fungus and held in bondage, being forced to elaborate starch by means of their chlorophyll from the inorganic material obtained by the rootlike filaments, which starch the fungus is able to feed upon. Some of the green cells are pushed out from time to time invested with a few wisps of fungus-threads, and so reproduce the partnership. It is but right to add that some good authorities on this branch of botany decline to accept these views, and still regard lichens as independent crganisms and not partnerships.

The species are very numerous, but their identification is not easy, and requires serious application. The two figured are exceedingly common in some districts. Various species of Cup-moss (Cladonia) will be met on heaths, sandy hedge-banks, etc. They have a flat crust-like base, from which arise pale grey tubes or cups, bearing at their tips the bright scarlet, pinky-brown, or even black fruits. A more common form in woods and on banks is Cladonia pyxidata, with the tube greatly increasing in width upwards. Cladonia rangiferina is the well-known Reindeer-moss, of inestimable value in extreme Northern latitudes as the food of the useful animal whose name it bears ; it may be found in abundance in this country on heaths and hillsides covering the ground beneath the heather. 
The other species figured in our plate, the Wall-lichen (Physcia parietina), is also very common, forming the familiar orange stains upon walls and maritime rocks. A closely allied species, the grey Parmelia saxatilis, is common on treetrunks : it has been used time out of mind in the production of a brownish-red dye for wools. Several others of the same genus are valuable in a similar direction : our own Parmelia perlata, which grows on tree trunks, is largely imported from the Canaries as a dye-weed, and has been sold at as high a rate as $£ 200$ per ton.

Lichens are generally of slow growth and long life. Mr. Berkeley kept watch upon a patch of Lecillia geographica for twenty-five years, and found little change in it all that time. The Rev. Hugh Macmillan recounts how he found on the top of Schiehallion a species of lichen encrusting quartz rocks, which exhibited beneath the lichen the marks of glacial action as distinct and unchanged by atmospheric effects as though the glacier had only passed over them yesterday. He suggests that the lichen may reckon its days back very nearly if not quite to the glacial period in Britain !

There are upwards of a thousand British species, and the best list of them will be found in "Crombie's British Museum Catalogue of Lichens," of which the first part was published in 1894.

\section{Mosses (Musci). Plate I 27.}

Another important tribe of flowerless plants, to which we must be content with merely giving the general characters, for in a volume primarily intended as a guide to wild-flowers we must not occupy too much space with plants that do not produce flowers. At the same time, we believe the nonbotanical among our readers will be glad to have a slight introduction, upon the strength of which they may cultivate the closer acquaintance of a most beautiful and interesting group of plants. 
A. Three-cornered Hypnum (Hypnum triquetrum) is a common species on woodland banks, growing in branching tufts. The stems are well clothed with leaves, which consist of a single layer of cells; there is therefore no necessity for the breathing pores (stomates) found on the leaves of flowering plants and giving access to the tissues beneath the cuticle. The leaves of mosses are not provided with stomates; neither are they stalked, but attached directly to the stem by their base. From the sides of the stem at intervals a number of brown, hair-like threads are given off, and each of these ends in a brown, pear-shaped nodding organ, the spore capsule. These capsules are each closed with a lid (operculum), beneath which is a double row of teeth, their tips directed towards the centre of the mouth. When the spores are ripe the operculum is cast off, and these teeth erect themselves to allow the minute spores to escape. The teeth (forming the peristome) of mosses are always some multiple of four; in Hypnum each row contains sixteen.

B. Beautiful Hair-moss (Polytrichum formosum) represents another division of mosses in which the fruits are borne on the termination of the stem or principal branches. In an earlier condition than that figured the capsule is covered with a conical densely-hairy cap (calyptra); this is thrown off when the spores are ripe, the operculum follows and the spores are cast.

\section{Mushrooms, and Toadstools (Fingi). Plate I 28.}

We cannot pretend to do other than call the rambler's attention to the interesting plants that are variously called mushrooms or toadstools, according to whether they are of the two or three species commonly eaten, or of the multitude concerning which the British public knows nothing, and therefore dismisses them as worthless toadstools. 
A. The Fly-Agaric (Agaricus muscarius), though in general structure it closely resembles the common mushroom $(A g$. campestris!, is to be avoided as a poisonous species. Its large orange or crimson cap, more or less thickly dotted with whitish flakes, is a very striking feature in woods in late summer and autumn. An examination of the underside of the cap (pilcus) will reveal a great number of thin yellowish plates set on edge and radiating from the stem to the circumference. Over these plates or giils is stretched a membrane, called the hymenium, on which the spores are borne. From this characteristic of the bulk of our mushrooms and toadstools the tribe containing them is dubbed the Hymenomycetes.

B. Edible Boletus (Boletus edulis). In this group (Polyporci) the hymenium, instead of investing gills, lines minute pores or tubes, with which the under surface of the pileus is packed, and in which the spores are produced. Many of the Buleti are Edible, but their good qualities are known only to the few in this country. Edulis may be distinguished from other species by a delicate network of raised white lines covering the stem.

: C. Jewelled Puff-ball (Lycoperdon gemmatum). This species represents a tribe in which the spore-bearing surface is contained within the fungus. In a young state Puff-balls of many kinds are filled with a white creamy substance, and so long as this remains white and does not change colour on being cut the fungus is good to eat, after being cut in slices and fried. $\mathrm{W}^{\prime}$ hen the spores are ripe the Puff-ball splits open at the top, and discloses a hollow filled with brown dust-the spores.- Certain species of Lycoperdon attain very large proportions : L. giganteum is abundant in some localities. in grassy places, usually measuring nine or ten inches in diameter, but occasionally it exceeds twenty inches, and weighs as many pounds. Slices may be cut from one side of it for several days in succession, but so lorig as the rooting portion is not interfered with it will continue to grow. L. gemmatum is. 
common on downs or pastures. Readers should be cautioned against eating these small species in a raw state, as such a course has been known to have serious effects.

D. Chanterelle (Cantharellus cibcrius). This belongs to the same section as the Fly-Agaric, in which the spore-bearing membrane is spread over gills; but in Cantharellus the gills are reduced to thick ribs that run from the edge of the pileus partly down the stem. The whole fungus is coloured with orange-yelluw, internally as well as the outside. It is often abundant in woods in summer and early autumn. It is much esteemed for its esculent qualities; but it requires much ccoking, and should first be thrown into hot water for a few minutes, then dried on a cloth, and fried or stewed gently. 


\section{Small-leaved Lime (Tilia parvifolia).}

Several species of Lime may be met in woods and plantations, but respecting the right of each to be called indigenous there is a good deal of difference of opinion among authorities. Some say the present species is a native and the Large-leaved Lime ( $T$. platyphyllos) not; others reverse this verdict and say that platyphyllos is certainly native, but that parvifolia is doubtfully so. There is little difference, other than the size of the leaves, between the two. Both are trees of sixty feet and upwards. The leaves are alternate, heart-shaped and toothed, lop-sided at the base, and about two and a half inches across in parvifolia, compared with four inches in platyphyllos. In July and August the Small-leaved Lime puts forth her yellowygreen blossoms arranged in cymes, the long stalk of which is furnished with a long pale-coloured bract. The flowers consist of five sepals, five petals, a great number of stamens, a five celled globular ovary with simple style and a five-toothed stigma. Only one of the cells matures its two ovules, so that the fruit is two-seeded. The flowers are sweet-scented, and very rich in honey.

The generic name, Tilia, is that by which the Romans knew the tree.

\section{Tree of the Gods (Ailintus glandulosa).}

This elegant shade-tree was introduced from North China in $175 \mathrm{I}$, and brought its name with it-Ailanto, or Tree of the Gods. It has, however, been better appreciated in France and Italy than in this country. It grows to a height of fifty or sixty feet. The leaves are compound, pinnate, a fact that might easily be overlooked, for the whole leaf is so largesometimes as much as six feet in length-that its stalk and mid-rib might well be mistaken for a branch clothed with 


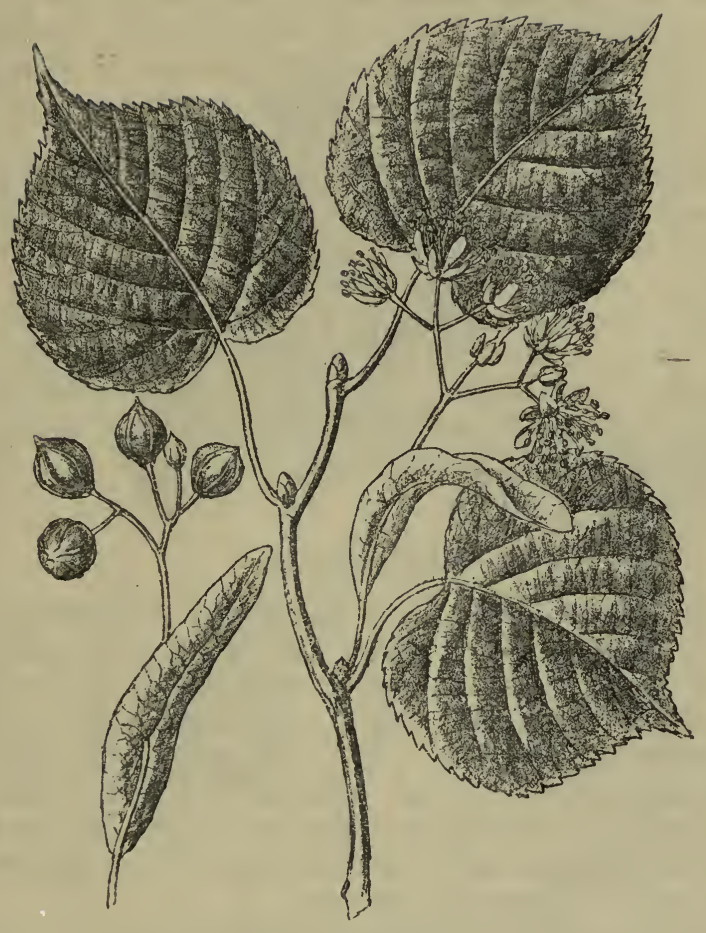

Small-leaved Lime.

Tilia parvifolia.

- Tiliace $A$. - 
opposite leaves. The leaflets are toothed, and the teeth bear glands on the lower side, whence the specific name. Its flowers, which open in August, are borne in clusters at the end of the branches. They are small, greenish-white in colour, and give off an evil odour. There are two forms of flowers, the one consisting of a five-parted calyx, five petals, and ten stamers; the other with calyx and petals the same, but fewer stamens and three, four, or five ovaries. The flowers are not represented in our illustration, the drawing having been made when the tree was in fruit. These will be seen to look like small imitations of ash-keys. It is a rapid grower in almost any soil, though it succeeds best in a light humid earth, and appreciates a little shelter. Its leaves are the favourite food of one of the large silk-producing moths (Attacus cynthia), but most other insects disapprove of it.

\section{Maples (Acer).}

Our English Maple is the Common or Small-leaved or Field Maple (Acer campestre) that grows wild in hedgerows and thickets in England and Wales, but is only naturalized in Scotland. It is a small spreading tree, scarcely exceeding twenty feet in height, with leaves five-lobed, the lobes again lobed or toothed. The flowers are small, green, in corymbs, with narrow sepals and narrower petals, succeeded by two-winged two-seeded fruits called samaras; the wings being horizontal. Flowers May and June.

The Great Maple or Sycamore (A. pseudo-platanus) is a tree commonly grown in the streets, squares, and parks of London and other great cities on account of its smoke-enduring qualities. It has been so long established here that it is generally but erroneously regarded as a native. It is a tree of very rapid growth, and attains a height of about eighty feet; living upwards of two hundred years. Leaves large, 


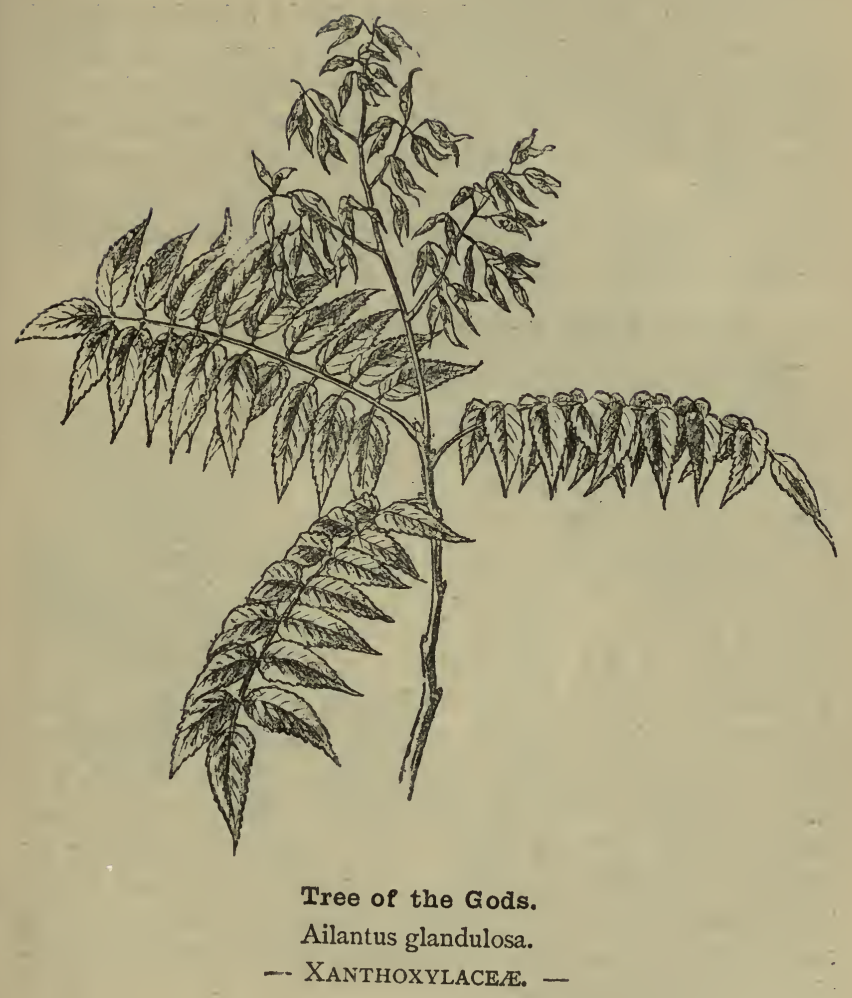


five-lobed, unequally toothed. Flowers, greenish-yellow, May and June. Samaras large, wings diverging. Native of MidEurope and Western Asia.

The False Sycamore or Norway Maple (A.platanoides) is the species shown in our figure. It is a native of Europe, introduced to England in 1683 . It is a considerable-sized tree, attaining a height of about sixty feet. Its leaves are heartshaped in outline, five-lobed, sharply pointed, with a few large sharp teeth. The flowers appear in April and May; bright yellow. The samaras are brown, the wings widely diverging.

Acer is the old Roman name for the Maple.

\section{The False Acacia (Robina pseudacacia).}

The False Acacia, Common Acacia, Robinia, or Locust-tree, as it is variously styled, is a native of mountain forests in North America, attaining its greatest perfection in Kentucky and Tennessee, where it attains the height of ninety feet and a diameter of four feet. It has been grown in this country for two hundred and fifty years, it being one of the earliest trees introduced from the New World, its graceful habit and light pinnate leaves commending it as an ornamental tree for the plantation. In the United States it is in great repute as an ornament, a shade or a timber-tree; it grows with great rapidity, and its timber is of great durability, so that our cousins use it largely for ship-building, railway sleepers, and fences. When William Cobbett visited the States he was greatly struck with the useful nature of this tree, and on his return to England spared no pains to make its virtues known to his countrymen, even starting a nursery for the purpose of supplying the young trees, and creating quite a rage for Locustplanting for several years.

The leaves are long, compound, the leaflets being arranged in a pinnate manner, with an odd leaflet. The stipules are in the form of prickles at the base of the leaf-stalk. It is a 


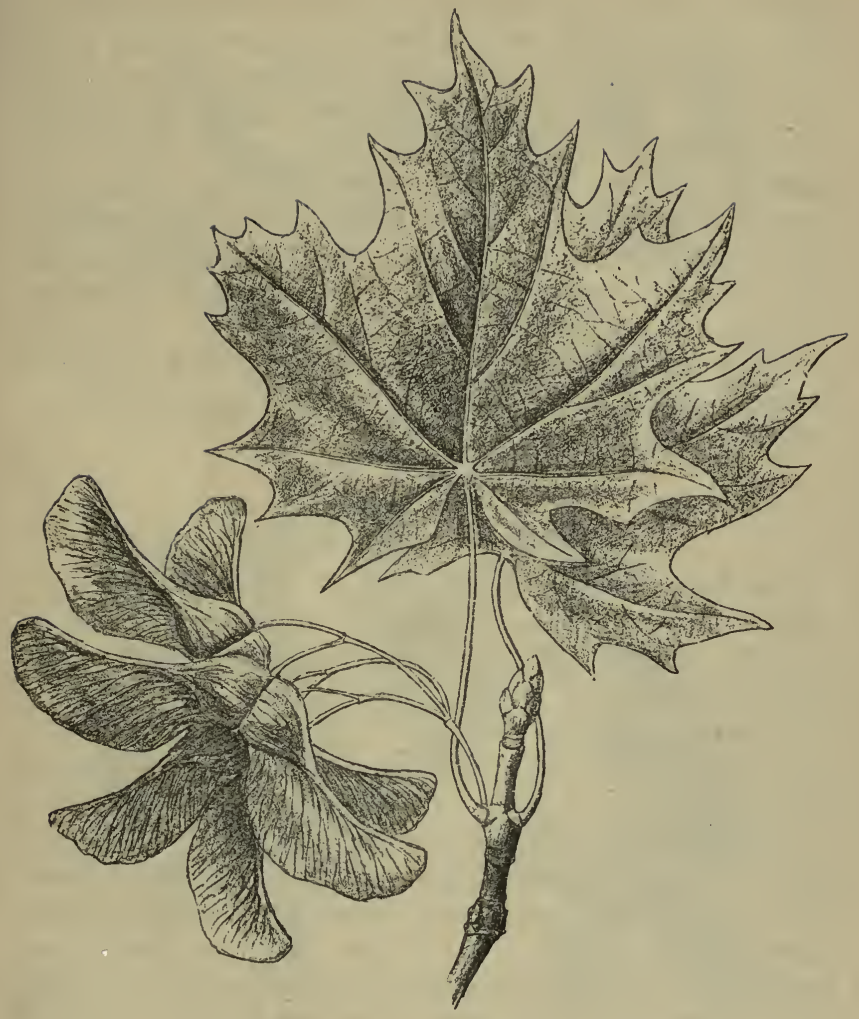

False Sycamore.

Acer platanoides.

- SAPINDACEÆ. - 
Leguminous plant, and its flowers greatly resemble those of the pea. They are white, sweei-scented, and gathered into a long, pendulous raceme, like that of the laburnum : May and June. The tree is sensitive, and on a branch being touched the leaves will all incline towards the branch, whilst each leaflet advances half-way towards its opposite fellow. The same movements occur at sunset, the leaflets then remaining folded face to face until dawn. The fruit (shown in figure) is that form of pod called a lomentum, in which the valves are constricted between the seeds.

The genus is named in honour of Jean Robin, a French botanist, whose son cultivated the first specimens of $R$. pseudacacia in Europe.

\section{The Ash (Fraxinus excelsior).}

One of the most pleasing in growth of our forest trees is the Ash, its grey trunk rising to eighty or a hundred feet, and its sweeping branches, the lower ones bending upwards at the tips, clothed with the gracefully curving long pinnate leaves. The character of these compound leaves and their leaflets is well shown in our illustration, together with two clusters of the winged fruits.

The Ash is a native of Britain, although most of the specimens we meet in woods and plantations have been reared in a nursery and planted out. There are many cultivated varieties of $F$. excelsior; and a large number of species have been introduced during the present and last centuries, chiefly from S. Europe and N. America. Ash and Privet are the only native representatives of the order Oleaceæ, to which the Olive belongs. It cannot be said that Fraxinus excelsior is a typical representative of the order, since most species included in it bear flowers composed of all the floral organs, whereas excelsior has neither calyx nor corolla. Its flowers appear in 


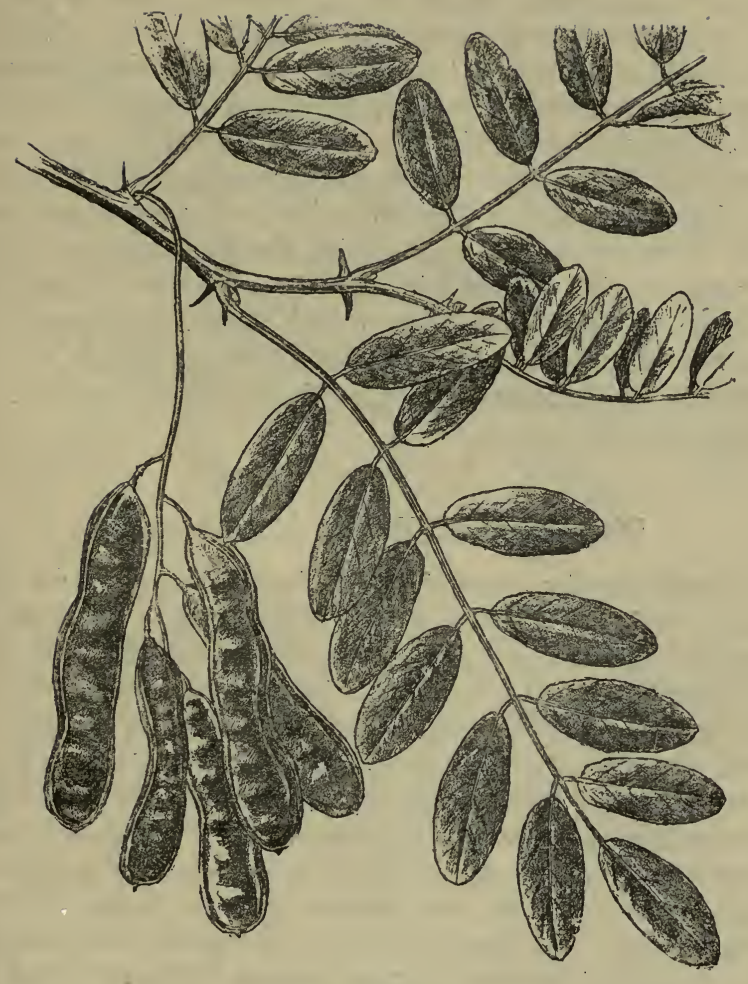

False Acacia

Robinia pseudacacia.

- I.eguminose. - 
April or May, and are of three kinds :-staminate, consisting of two dark purple stamens only; pistillate, consisting of an oblong ovary with short style and cleft stigma ; hermaphrodite, consisting of ovary and two anthers with very short filaments. These flowers are individually small and inconspicuous, but associated as they are in dense panicles from the new wood formed in the previous season, and appearing before the black leaf-buds have burst; they are collectively very conspicuous. The leaves are very late in making their appearance, as they are among the first to fall after the early frosts of autumn. The "keys," as the fruits are called, each contain two seeds, and the wing has a twist which causes the key to spin rapidly when the breeze separates it from the bunch and carries it far from the parent tree.

\section{The Black Mulberry (Morus nigra).}

It may surprise some of our readers to learn that the Mulberry-tree is not a native, though it is a familiar object in old gardens and parks. It is generally stated that the first Mulberry-trees were introduced in 1548 and planted at Syon House, Isleworth (then the Convent of St. Bridget of Zion), but the Duke of Northumberland is credited with saying early in the present century that he could then trace them back quite three hundred years. Several of this batch are still living, and one-probably the finest old Mulberry in England-is a hale and vigorous ornament to Mr. George Manville Fenn's lawn at Syon Lodge. Mr. Leo Grindon is of opinion that the tree was originally introduced by the Romans, for he finds that the Saxons had a name for it, which would probably not have been the case had it not been growing in their midst.

In this country the Black Mulberry does not reach a greater height than about thirty feet, its branches spreading out near the ground and attaining considerable thickness. The leaves 


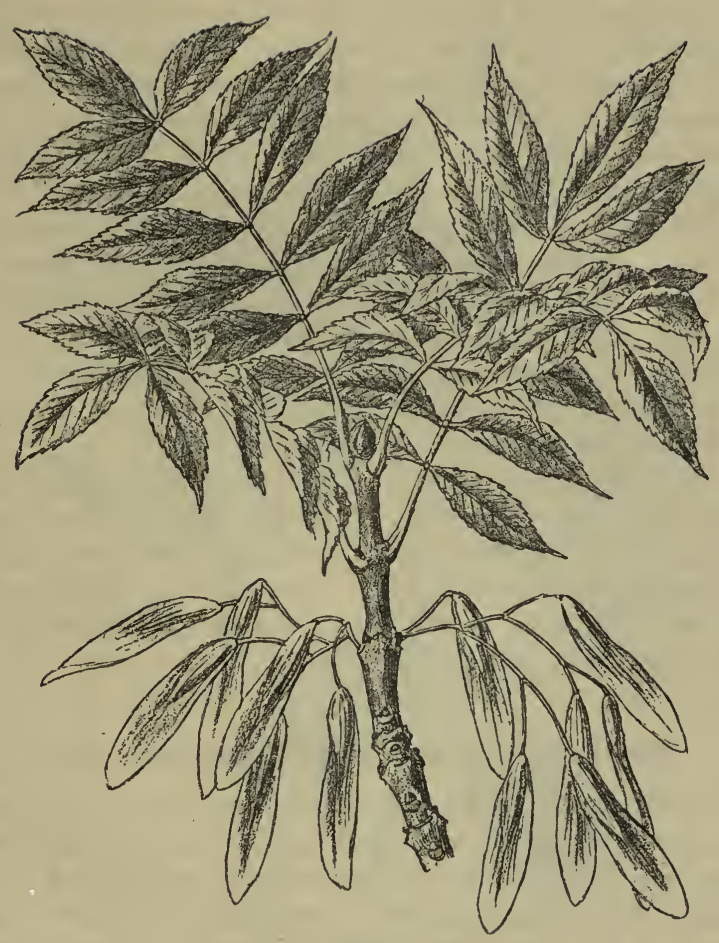

Ash.

Fraxinus excelsior.

- Oleace 
are large and rough, heart-shaped, and very plentiful, so that the tree affords good shade. The flowers are small and inconspicuous, of a greenish-white colour, the sexes separate, though sometimes on the same tree. The male or staminate flowers consist of a four-leaved perianth, enclosing four stamens, a large number of the blossoms being combined in a catkinlike spike, depending from the axils of the leaves. The female spike is shorter, and the individual flower consists of a fourparted perianth, enclosing the ovary and its two branched stigma. After fertilization the perianth becomes plump and succulent, and all on the one spike become so pressed together by their great increase in size that they form a multiple fruit, having a slight resemblance to the fruit of the Bramble (the produce of one flower), but really differing from it greatly. Mulberries are ripe in August or September.

The leaves do not unfold from the bud until the cold weather is well over, usually in May. It is said that its Latin name Morus is derived from mora, delay, in consequence of this caution on the part of the tree. The leaves generally used in the silk.culture for feeding the "worms" are those of the White Mulberry (Morus alba).

\section{The Small-leaved Elm (Ulmus campestris).}

The Elm is one of our commonest trees, yet a great amount of uncertainty appears to prevail in the popular mind in identifying the Common or Small-leaved from our second British species, the variously-named Scotch Elm, Wych Elm, Witch Hazel, or Mountain Elm (Ulmus montana). There is something more than a suspicion that campestris is not strictly indigenous, but it settled in the country so many hundreds of years ago (brought hither, some say, by returning Crusaders) that it would appear ungenerous at this date to question its claims to be called British, especially as it is more widely 


\section{$-{ }^{1} 38-$}

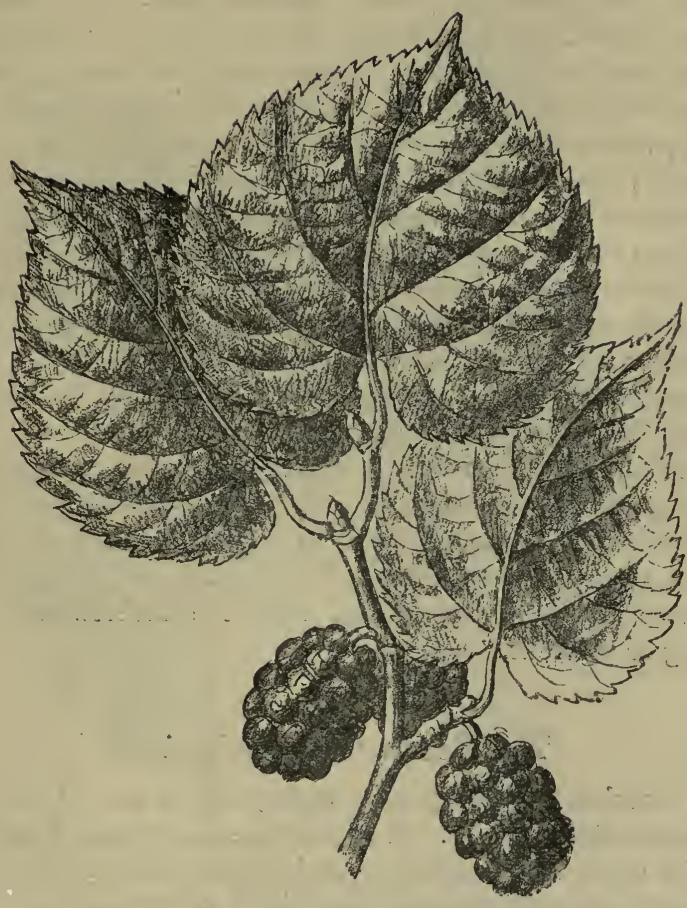

\section{Black Mulberrs.}

Morus nigra.

- Arctocarpe⿸尸 - 
diffused than montana. The Elms are both tall trees, but campestris usually attains a slightly greater height than montana, though the latter has a much stouter trunk. Their flowers appear before the leaves, and, although they are individually minute and inconspicuous, they are united in bundles, and the colour of the perianth and stamens renders them conspicuous. The perianth is bell-shaped, cleft into five or more lobes, reddish; the purple anthers are equal in number with the divisions of the perianth, to which their filaments are attached. The two styles are awl-shaped, their inner surfaces stigmatic. The flower-cluster is succeeded by a bunch of one-seeded samaras, winged all round. In montana the seed is placed in the centre of the samaras; in campestris it is distinctly above the centre. The leaves of montana are as large again as those of campestris, broader at the base, more inclined to be unequally heart-shaped. There are, however, many varieties of each, which make the identification of the species often very difficult.

The flowers appear in March and April, those of campestris a little earlier than the others. The name is the Latin word for the tree but probably derived from the Hebrew $u l$, to be strong or vigorous.

\section{The Beech (Fagus sylvatica).}

A Beech-tree growing on a chalky hill is one of the most beautiful of forest trees. It is, moreover, a tree that has left its marks upon our topography and literature, for many placenames (such as Buckingham, Buckland, Bookham) record the fact that in early times Beeches grew plentifully in the neighbourhood, and book is a survival of the period when the Runic poems were written upon slabs of Buk.

Without being at all glossy, like portions of the Birch and Cherry, the bark of the Beech is smooth, and remarkably even If allowed to grow naturally, without the pollarding which has 


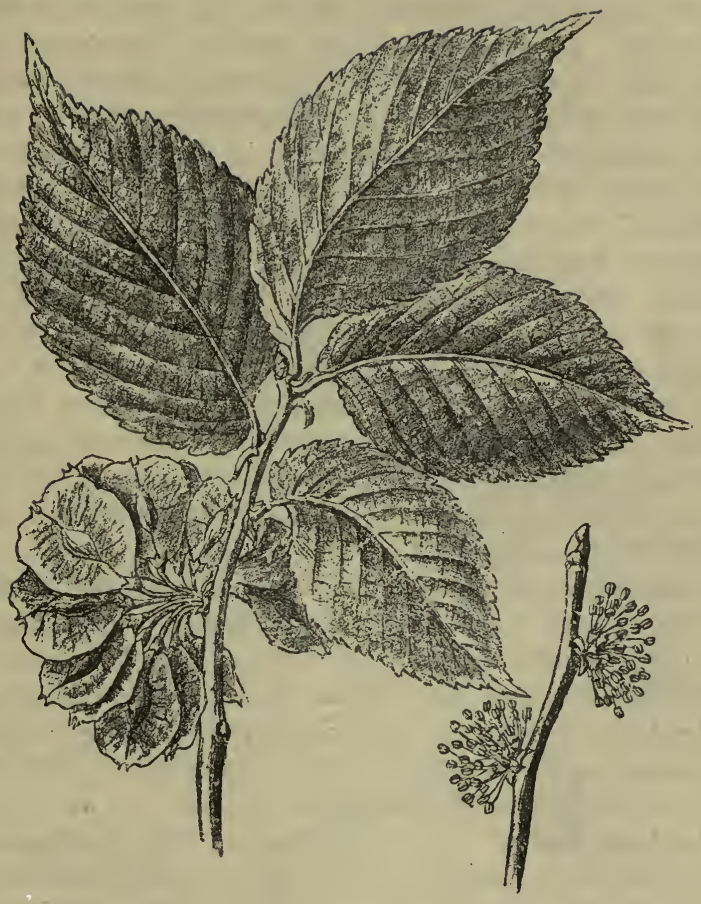

Common Elm.

Ulmus campestris.

- URTICACEA. - 
produced such picturesque monsters as those at Burnham, the Beech-trunk grows clean and straight to a great height, sending off slender, more or less down ward-bending, branches with shiny red skins. The twigs bear long, slender, fine-pointed brown buds that are closely mimicked by the snail Clausilia laminata, that loves to haunt the mossy angles between its large spreading roots, and to climb at even up its trunk, which from its smoothness and grey colour is far more suggestive of the gothic column than is the ruddy pine-stem. In spring these buds expand and drop off as the rising sap swells the rolled-up leaves within, which emerge bright silky things, plaited, and edged with the most delicate fringe of gossamer, that gleams in the April sunshine. Then the Beech is indeed a thing of beauty, fair and majestic. The Birch has well been styled by Coleridge "The Lady of the Woods," but the Beech is surely entitled to take higher rank as the Queen of the Forest, especially in the spring, when covered with this bright and tender foliage, amidst which the flowers are lost.

As summer comes the silken fringe of the leaves is cast off as they become firmer in texture, thicker, and more opaque of tint; yet smooth, and with a character peculiarly their own. With the advent of autumn the leaves become crisp, and turn to red-gold, or crimson, or warm ruddy brown. Then, when the afternoon sunbeams fall upon the Beech-wood, it seems all on fire, and the autumnal glories of every other tree are eclipsed.

In April or May the Beech flowers. The blossoms are of two kinds, male and female, produced on stalks from the axils. The male flowers are combined in threes or fours within an involucre, forming a silky tassel as it hangs downwards with its yellow anthers waving. The individual flower has a bellshaped, five or six-lobed perianth, with a varying number of stamens. Nearer the growing end of the twig rise the female flowers on shorter stalks. They are usually two or four together, in a silky-haired, four-parted involucre, known as a 


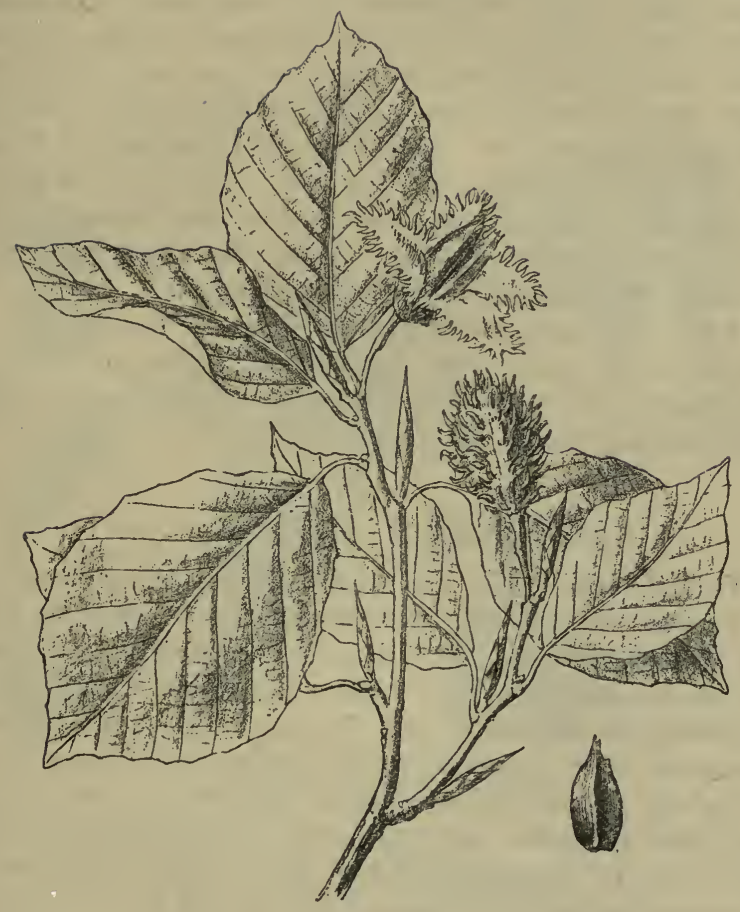

Beech.

Fagus sylvatica.

- Cupulifere. - 
cupule. Individually these female flowers possess a perianth whose mouth is minutely toothed, within which is a three-sided, three-celled ovary surmounted by three slender spreading styles and stigmas. As the three-cornered fruits grow and ripen the cupule becomes hard and its outer scales spiny; the four valves part and turn back to disclose and set free the smooth brown nuts or " mast," beloved of swine. In France an oil is expressed from the mast, and the latter is also used as a food for poultry, like its namesake, the Buckwheat (see page I18). It is from these edible qualities that the genus gets its name, derived from the Greek, phago-to eat.

There are many varieties of the Common Beech to be met in plantations, such as the Copper Beech, the Purple Beech, the Variegated Beech, the Cut-leaved Beech, the Crested Beech, the Weeping Beech, the White Beech, etc.

\section{Sweet Chestnut (Castanea vulgaris).}

On light sandy soils, where little else but fir and heath will grow, one may meet with considerable plantations of the Sweet or Spanish Chestnut. For centuries, and until quite recently, it was considered to be a native; but it is never found here forming natural forests, and only in the South in favourable situations does it ripen its fruit-usually small. Great plausibility was given to the supposition that Castanea was a native by the oft-repeated statement that its timber was to be seen in the roof of Westminster Abbey and in other old buildings. An examination of this timber years ago by Dr. Lindley - the eminent botanist-proved it to be oak, which it closely resembles. Again it was claimed as British on account of the great antiquity of certain living trees, such as "the great Chestnut of Tortworth," a name it bore in the reign of Stephen, when it must have been an ancient tree. It is now generally understood that the Chestnut was brought hither by the 


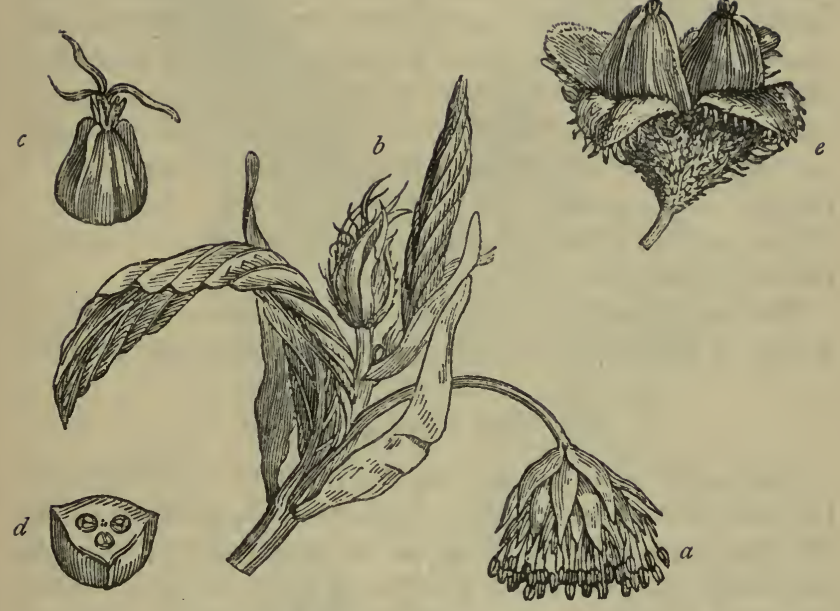

Flowers and Fruit of Beech.

a. Male flowers.

b. Female flowers in cupule.

c. Ovary and stigmas removed from cupule.

d. Section of ovary, showing the three cells.

¿. Ripe cupule open, showing nuts. 
Romans, and that it got a more permanent footing on our land than its importers. It is grown chiefly for the sake of its young wood as hop-poles, fence-posts, and hoops. Unlike the oak, its timber deteriorates with age.

It is distinctly an acquisition to our woods and plantations, its long, toothed, shining leaves being fine both in shape and colour. Its male flowers are produced in long, yellow catkins, consisting of a great number of six-parted perianths ; from these depend from ten to fifteen stamens, which discharge great quantities of pollen. The female flowers are borne in threes within an involucre (cupule), and each has its perianth adhering to the ovary; there are from five to eight cells in the ovary, and a similar number of stigmas, but, as a rule, only one cell matures one of its two ovules.

The name is said to be derived from Castanum, the name of a town in Thessaly whence the Romans first obtained the fruit.

\section{The Oak (Quercus robur).}

First and foremost in any list of British trees should come the Oak, in utter disregard of all botanical classification, for not only was our supremacy of the sea and our existence as a nation gained by aid of our oaken walls, but a grand old Oak is finely typical of British solidity, strength and endurance. Fifteen years may be regarded as the average age at which the oak first produces its fruit, the acorn, and it continues to ripen its annual crop for centuries. Dryden has certainly not exaggerated in his lines that tell how-

"The monarch oak, the patriarch of trees,

Shoots rising up, and spreads by slow degrees;

Three centuries he grows, and three he stays,

Supreme in state, and in three more decays."

According to the records and traditions relating to many hollow ruins of enormous girth still living at their circumference though long since dead at heart, Dryden's nine-century tree is only 


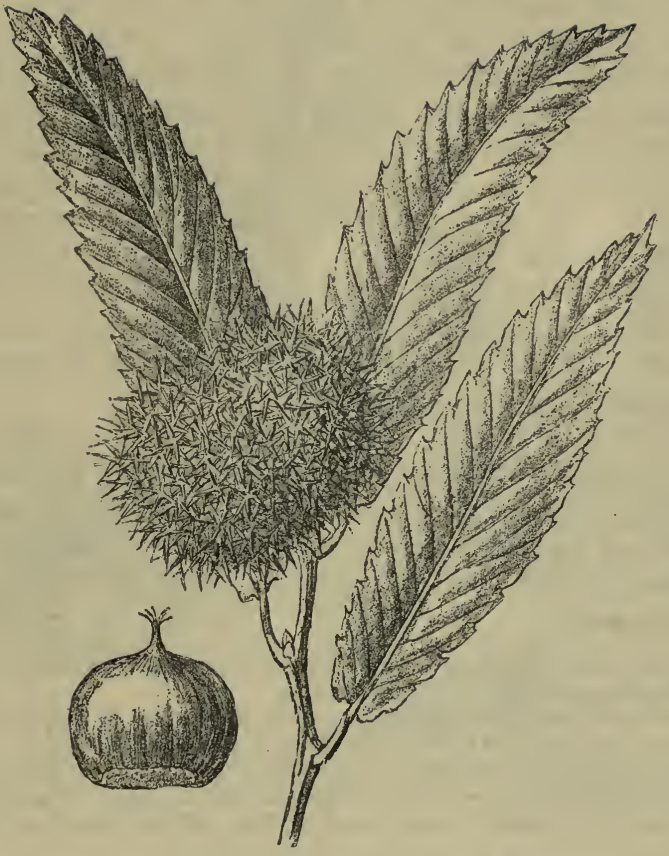

\section{Sweet Chestnut.}

Castanea vulgaris.

- Cupulifere. 
middle-aged. Well-nigh every district in this country, not too high above sea-level, can show its monster Oak; but it: is where the soil is close and heavy that it is seen at its best. There is no doubt about the Oak being a true native. Some of our Oak-forests are older than history : such was the forest of the Weald-Anderides-leag-in which the aboriginal Britons so long withstood the attempts of Romans and English to conquer them, and which at a much later date supplied alike much iron from its quarries and the oak charcoal wherewith to smelt it; and of which to-day the pedestriari-tourist from London to the South Coast will cross many considerable fragments. How widely it was grown is evident from the vast number of place-names of which it forms part, such as Okham, Ockshott, Ockley, Acton, Acworth, Acrington, Okehampton, Oxted, etc.

Our British Oak is Quercus robur, of which there are several varieties to which some authorities give specific rank, but their characters are too inconstant to be so regarded. However, as they are frequently called by their distinctive names, it were well to mention them and their chief differences.

White Oak (Q. robur, var. pedunculata) has the leaves slightly stalked or stalkless, and the acorns with long, slender stalks.

Red Oak (Q. robur, var. sessilifiora) has the leaves borne on long yellow stalks, and the acorns supported on very short stalks, or quite stalkless (sessile).

Durmast ( $Q$. robur, var. intermedia), with acorns and leaves on short stalks, and the underside of the leaves downy. Spiders are sald to object to the wood of this tree, and will not spin their webs where it has been used for building yurposes.

The flowers of the Oak are of two distinct sexes. Those bearing stamens are grouped on a long, slender and pendulous catkin; each consisting of a four- to seven-lobed calyx, within which are ten stamens. The females are solitary and erect, consisting of a cupule, within which is a three- to eight-lobed calyx, a three-celled ovary with three styles. The cupule becomes the familiar "cup" of the acorn, which again is the 


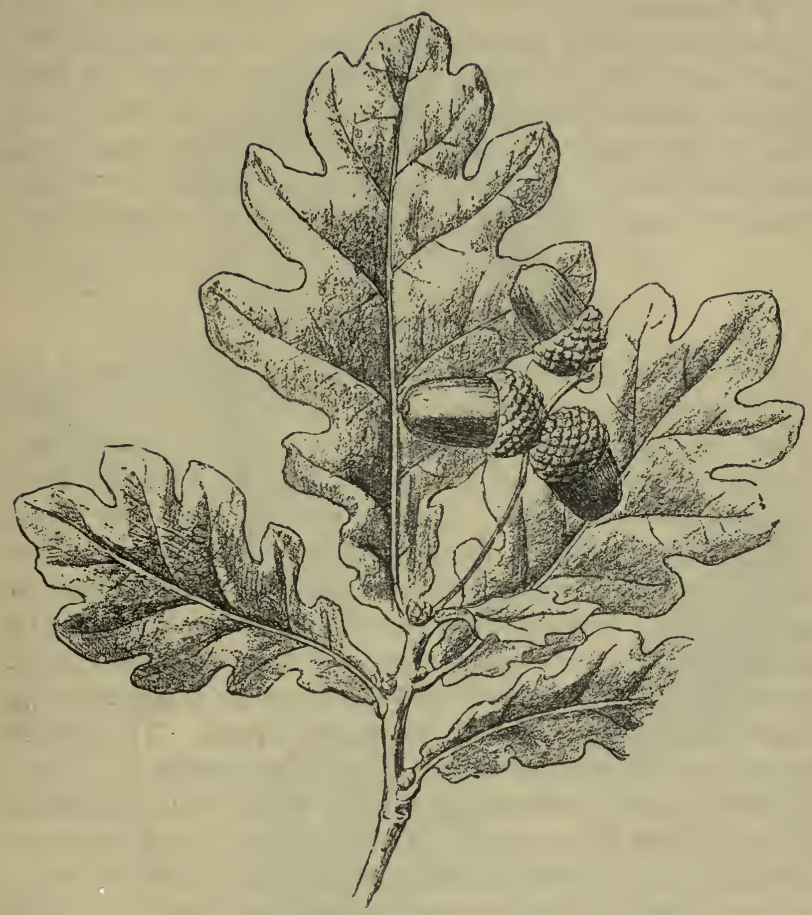

White Oak.

Quercus robur, var. pedunculata.

- Cupulifere. - 
enlarged ovary, two cells of which have aborted. Flowers April and May.

The Oak forms the world of a great number of insects, many of which are either parasites (gall-flies which produce Oakapples, bullet-galls, spangles, and other forms of gall) or their lodgers. Several fungi, too, specially select old Oaks upon which to live freely. Chief among these is the remarkable Beef-steak fungus (Fistulina hepatica), of which in October a hundred-weight might be quickly gathered in an oakwood.

\section{Hazel (Corylus avellana).}

The Hazel is one of the most look-ahead kind of trees, for almost before this year's nuts have all dropped off, or been picked off, she puts out the tiny, cylindric grey bodies that continue to lengthen all the winter and by February have become loose and open. Then it can be seen that these catkins consist of male flowers, for the yellow stamens are evident, and soon every breeze shakes out a little cloud of yellow pollen. Looked at analytically, the catkin is seen to be made up of a large number of scaly bracts, of which one large and two small go to a flower, and these are so arranged as to form a pent-house roof over the eight stamens. The female flowers are altogether different. They each consist of a twocelled ovary, with two slender, crimson styles, and enclosed in a kind of calyx, three-parted. Two of these flowers are then associated in a bud-like involucre, situated at the end of a twig. In spring, before the leaves appear, these open and the crimson stigmas are put forth to catch a little of the flying pollen. By September one cell of the ovary has developed into a hard shell containing one large seed (kernel) and clasped by a large raggedly-cut hood-the developed involucre.

When the tips of the nutshells become brown-tinged, then appear boys, squirrels, dormice and nuthatches, and by their 


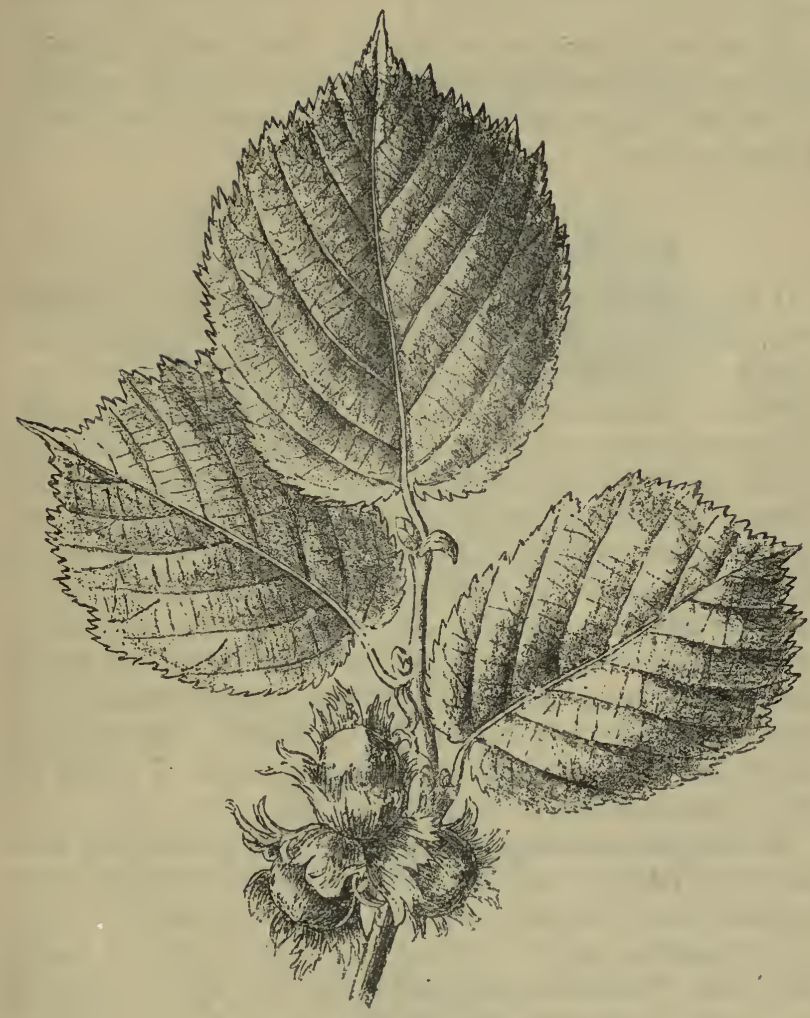

Hazel.

Corylus avellana.

- Cupulifere. - 
combined industry the tree or bush is soon despoiled of its load.

All the many varieties of Filberts, Kentish-Cobs, Spanishnuts, and Barcelona-nuts are but varieties of Corylus avellana. The name is from the Greek, Korus, a helmet, from the form of the involucre.

\section{The Hornbeam (Carpinus betulus).}

It is in our experience that though many townsmen think they know the Beech there are comparatively few of them that cannot be deceived into accepting the Hornbeam as Fagus sylvatica. It must be admitted that there is a strong superficial resemblance to a small Beech ; but on closer examination it will be found that the differences are greater than the likeness. The Hornbeam has a light-grey smooth bark, but instead of the very round trunk of the Beech, that of the Hornbeam appears to have been laterally squeezed, for the diameter taken one way is longer or shorter than if taken at right angles to the first measurement. Then again the leaf of Carpinus if placed upon that of Fagus will be found to bə much less rotund in proportion to its length; the surface is rough, and instead of the cleanly cut margins of Fagus we have a coarse double-toothing.

The Hornbeam when full-grown is a much smaller tree than the Beech, rarely exceeding seventy feet in height, with a trunk circumference of ten feet ; whereas the Beech reaches a height of considerably over a hundred feet, with a girth of nearly thirty feet. When naturally grown, too, it is by no means so picturesque as the Beech, but in places where it is most plentiful, as in Essex, especially Epping Forest, it is generally pollarded, and seldom allowed to exhibit its true form.

The male flowers form a pendulous catkin, originating in the axils, and each consisting of an egg-shaped bract, holding 


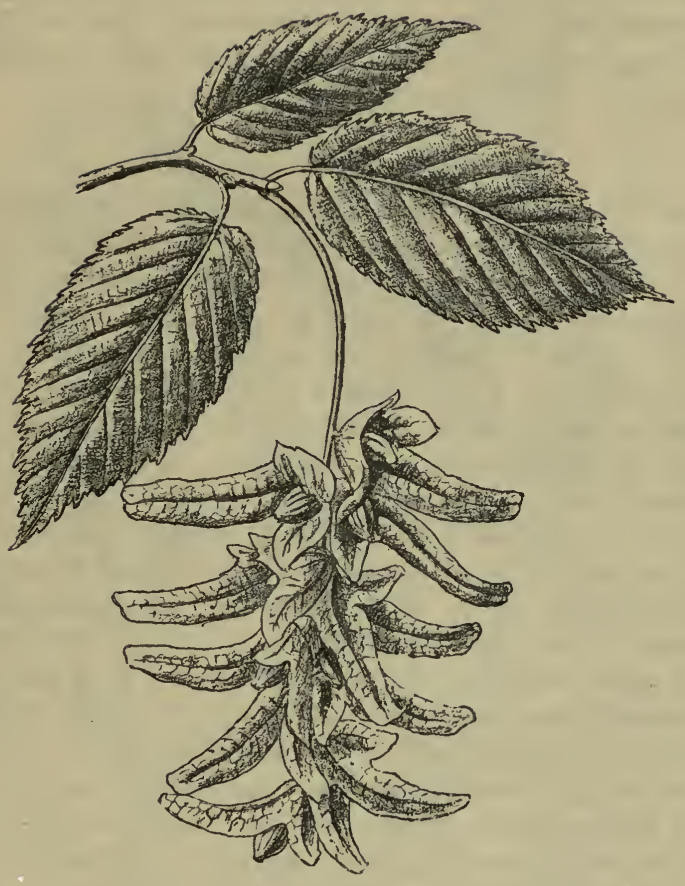

Hornbeam.

Carpinus betulus.

- Cupulifere. - 
about a dozen stamens at its base. The female flowers form an erect flower-head, shaped like an artichoke at the end of a twig, the three-lobed bracts each containing two flowers. After fertilization these lobes enlarge considerably, and the flowerhead lengthens into the pendulous string of fruits shown in our illustration. The flowers appear in May.

\section{The Osier (Salix viminalis).}

The Willow family, to which the Osier belongs, is, like the Brambles, a difficult group even for the botanist, and he is a bold man or a very clever one who undertakes to identify specimens off-hand. They have suffered much at the hands of the "splitter." Hooker gives the number of British species as eighteen, with a considerable number of varieties; but by Babington many of these varieties are given specific rank, and his list of species runs to fifty-eight. It would, of course, be absurd for us to attempt in this restricted space to give a key even to Hooker's list ; but our details of the flower structure, etc., will be found to apply in the main to all willows, and for a knowledge of the other species our readers must refer to Hooker. It should be added that, to increase the difficulties of the botanist, the plants that bear male flowers as a rule differ consiclerably from those that produce female flowers; for with scarcely an exception each plant is of one sex only.

The Osier (S. viminalis) is one of our most common species, and is the one most generally used for basket-weaving. It is a large shrub or low bushy tree, growing in wet places beside rivers and pools, or more frequently in Osier-beds. When allowed to grow uncut it attains a height of twenty or thirty feet; its long, smooth, and straight branches well furnished with very narrow leaves, tapering to a fine point, and sometimes nearly a foot in length. The margins of the leaf are quite free from teeth or lobes, and are curled back on the shining white silky underside. Both male and female flowers form catkins: 
$-{ }_{146}-$

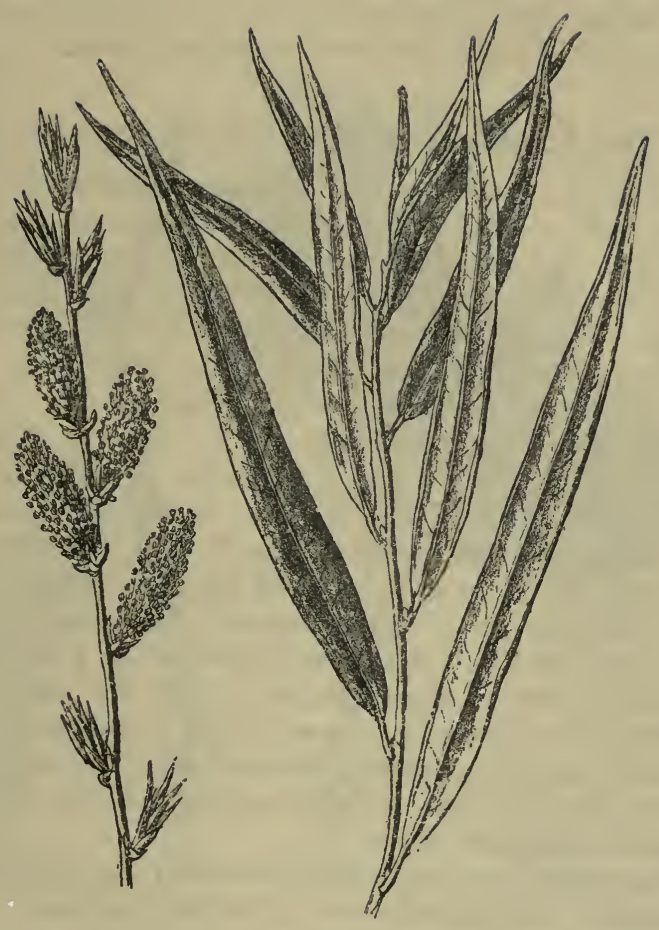

Osier.

Salix viminalis.

- Salicinex. - 
the males each consisting of a hairy scale, to which are attached two stamens; the females of a similar scale bearing the ovary. The catkins appear before the leaves, in March or April. Salix is the old Latin name for Willows and Osiers.

\section{The Lombardy Poplar (Populus fastigiata).}

It is an easy step from the Willows to the Poplars, for the Genus Salix and the Genus Populus together form the Order Salicinex. We have only two indigenous species in Britainthe White Poplar or Abele $(P$. alba), and the Aspen $(P$. tremula). In spite of the fact that it was not introduced until $\mathrm{I} 75^{8}$ it may safely be said that the Lombardy Poplar is now a better known tree than either of our native species. It is the tree that is so frequently planted as a live screen, to break the force of the wind or to hide some undesirable prospect. Its growth is most rapid, and the story is told of a man who planted this tree in his garden at Great Tew, in Oxfordshire, and was living fifty years after, by which time his tree had beaten him considerably in the matter of growth, being then a hundred and twenty-five feet high! But like most other trees of rapid growth it attains no great age-for a tree, that is-and it is doubtful if it exceeds a century of life. The whole of its branches and shoots take an upward direction, which gives the tree the fastigiate or sharp-pointed outline which has suggested its specific name.

In our native Poplars the shoots are downy ; in fastigiata they are smooth. The leaves are borne on long compressed stalks, which give them the ever-tremulous movement so well known in connection with the Aspen. As in the Willows, the sexes are on separate trees, and the flowers all in catkins. There is no perianth, a single bract-like scale serving instead, though there is a cup-shaped organ, within which is found, in one plant, a one-celled ovary, and in the other sex from twelve to twenty 


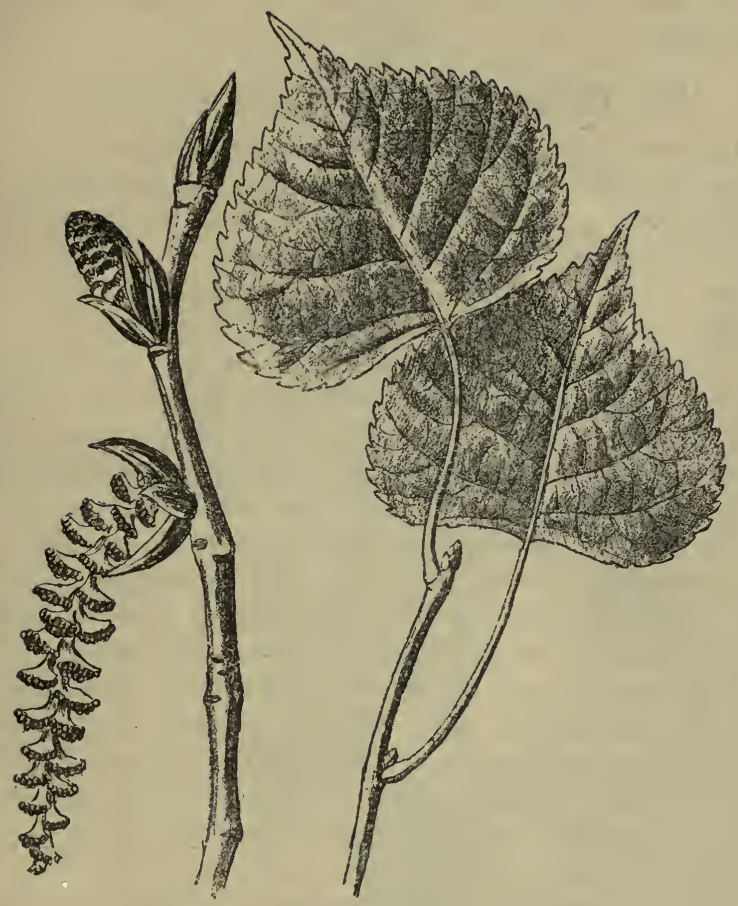

Lombardy Poplar.

Populus fastigiata.

- Salicine $e_{0}$ - 
stamens with red anthers are attached to the uncler-side of the cup.

The name of the genus Populus is the old Latin for Poplar and Aspen.

\section{The Oriental Plane (Platanus orientalis).}

One need not go far into the country in order to see the Plane. Its virtue as a smoke-proof tree has now been well tested by the governing authorities in large towns, and it is freely planted in recreation grounds and by the sides of broad thoroughfares. In London it must now be about the commonest tree; and some of the specimens grown in the west-end squares are very fine. Several of the London Planes have become quite "lions," to be seen by all visitors who "do" the Metropolis; such is the individual that overtops the old-fashioned houses at the corner of Wood Street, Cheapside. More celebrated, perliaps, is the Stationers' Hall Court tree, which, though only about sixty-five years old, is so important a feature of that corner of the City that, on the rumour that it was to be cut down a few years since to allow of certain improvements in the court, the denizens of Paternoster Row ard the precincts were up in arms, and evinced such indignation that the building plans of the Stationers' Company were modified, and the tree spared to delight the sparrows of the vicinity, and to bring thoughts of the country into the hearts of the publishing and bookselling fraternity who daily pour through the court.

In spite of its apparent enjoyment of London smoke and fog the plane-tree is not even a Britisher. Its introduction to England has been credited to Francis Bacon, but Loudon declares it was in our gardens prior to 1548 -thirteen years before the birth of the Lord Keeper.

The leaves of the Plane are very similar to those of the Sycamore and False-Sycamore (see page I34), but one feature 


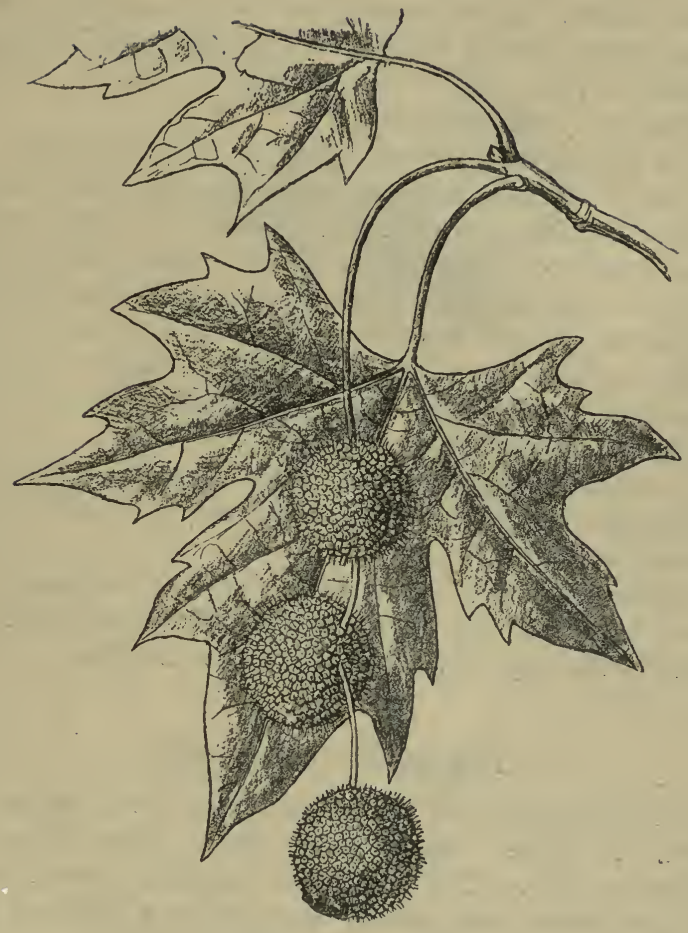

Oriental Plane.

Platanus orientalis.

- Platanaceze. - 
will serve to identify it at any season-the pale yellow patches on the trunk of the Plane caused by its constant shedding of flakes of bark. In the autumn, too, there is a striking contrast between the winged samaras of Acer and the ball-fruits of Platamus. Acer, again, has the leaves opposite, whilst in Platanus they are alternate.

The Planes are lofty trees (sixty to eighty feet), with thick cylindrical trunks, wide-spreading branches and abundant foliage. The leaves are five-lobed, with a few coarse teeth, and smooth-surface. The flowers of both sexes are in globular clusters and borne on the same tree, but on separate branches. The male flowers have a perianth of four narrow leaves alternating with the stamens. The female flowers consist of a one-seeded ovary with a curved style, one side of which is stigmatic. Flowers April and May.

$P$. occidentalis, the Western Plane, is very similar, but its leaves have red stalks, and are less deeply lobed and toothed; its bark scales less.

Platanus is the old Greek name for the Plane-tree, and is probably derived from Platos, breadth, in allusion to the broad leaves or the ample shade afforded by its branches.

\section{The Birch (Betula alba).}

The most graceful of our native trees is the White or Silver Birch. It is the very antipodes among trees of the solid unbending oak. The slim stem, scarcely ever a foot in diameter, tapers away almost to nothing at a height of fifty or sixty feet. This is at full maturity at forty or fifty years; thereafter it makes little progress, and it is believed not to reach far beyond its hundredth year. It has the singular reputation for producing a bark that is more enduring than its timber. In spite of its effeminate grace it is a most hardy tree, and stands alone on the bleakest hillsides, and is the only tree that endures the 


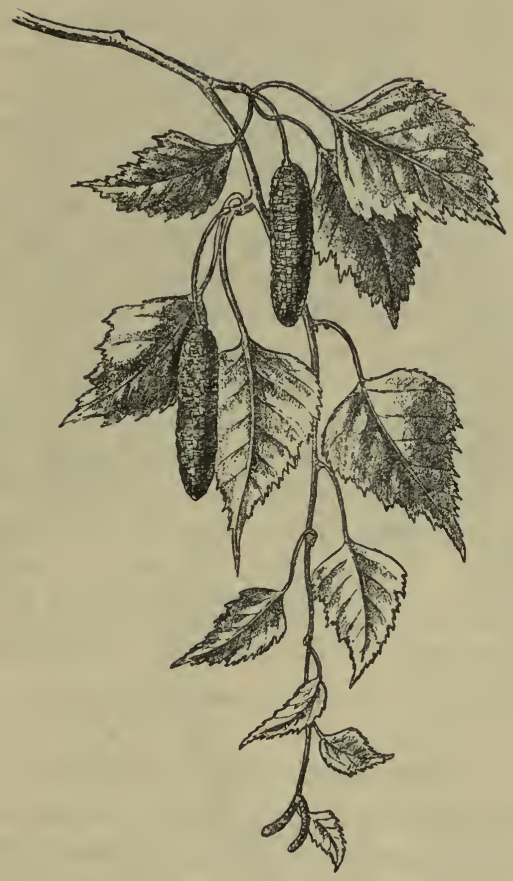

Birch.

Betula alba.

- Cupulifere. - 
rigorous climate of Greenland, though there, of course, it is greatly diminished in stature.

The leaf varies slightly in outline from oval with a point to a rhombic form, with a long slender stalk, and the edges are doubly toothed. The silvery-white bark is continually discarding its outermost layer, which peels off in ragged, tissuepaper-like strips, revealing the newer; whiter bark beneath. In this country it is used in tanning, but in the far Northern parts of Europe it is put to a variety of uses. The inflorescence is a catkin, the sexes separate, but borne by the same tree. The flowers of the pendulous male catkin consist each of a single sepal with two stamens, the filaments of which are forked, each branch bearing one anther cell, so that each stamen looks like two. The female spike, which is more erect, and shorter, is composed of three-lobed bracts, each containing two or three flowers. These are simply two-celled ovaries, with two styles and stigmas. The fruit is round, flattened, with a notched broad wing. It flowers in April and May.

There is one other Native species, the Dwarf Birch (B. nana), a bush of no more han three feet in height, which occurs locally in the mountain districts of Scotland and Northumberland. The leaves are very small, round with rounded teeth; smooth, dark green, and with a short stalk. The seeds have very narrow wings. Flowers in May.

The name Betula is the old Latin designation for this tree.

\section{The Alder (Alnus glutinosa).}

The Alder, of which we have but one species, is own cousin to the Birch, but we must not seek it in similar situations. The Birch loves the breezy hillside, the Alder prefers the swampy valley, the pond and river-side, its tastes being more thoroughly aquatic even than those of the Willows. Its bark has some resemblance to that of the Birch, especially when young, but in later life is more rugged, and very dark. The leaves are nearly round, doubly toothed, and with short stalks. When young they are sticky, as are the young shoots. The male catkins are 

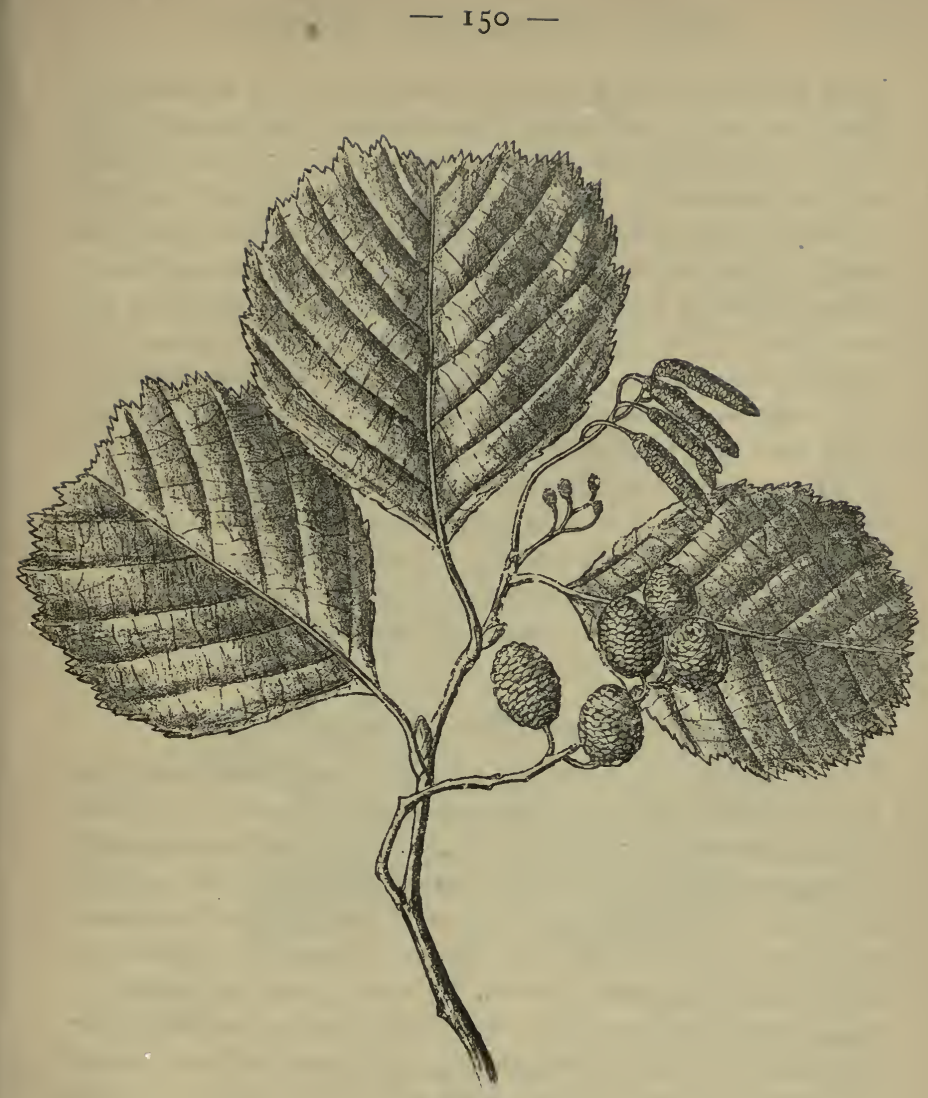

\section{Alder.}

Alnus glutinosa.

- Cupulifere. - 
long, produced, like those of the Hazel, late in autumn; the round red scales each holding three flowers, consisting of three, four or five sepals, and as many stamens. The female spikes are not produced till spring : they are more globular, and resemble minute cedar cones. The scales are reddish-brown and fleshy, afterwards becoming hard and woody ; there are two or three flowers in each, consisting of two sepals, an ovary and two styles. When ripe (October) the thick scales separate and set free the pale-brown nuts, which are very slightly winged.

In suitable situations the Alder attains a stature of forty to sixty feet, and reaches maturity in about sixty years. The wood is soft and white, but turns orange by exposure after cutting. Under water it is very enduring, all but imperishable, and the Rialto at Venice is said to be built on Alder-piles. It is greatly used in the manufacture of gunpowder.

Ainus is the old Latin name for the tree, and for a boat.

\section{Scotch-fir or Pine (Pinus syliestris).}

This, the Juniper, and the Yew are the only coniferous trees we have in Britain. Pinus sylvestris is therefore our only Pine, yet people persist in calling it a Fir, a name more especially belonging to the genus Abies. Time was when this beautiful tree grew wild in many parts of Britain; it is now found naturally in but a few places, from Yorkshire northwards; otherwhere it has been planted. We may easily tell whether a cone-bearing tree before. us is a Pine or not by exanining the leaf-cluster. If the leaves are in twos, threes, or fives, bound together at the base by thin, chaffy scales, it is a Pine. Should they be in twos, the leaves will be found to be half-rounded; if in threes or fives, they will be triangular in section. The cones, or fruits, of the Pines take two years to ripen. The scales of which the cones are made up are thicker at the free end, so that the outer surface of eacli scale is pyramidal. 


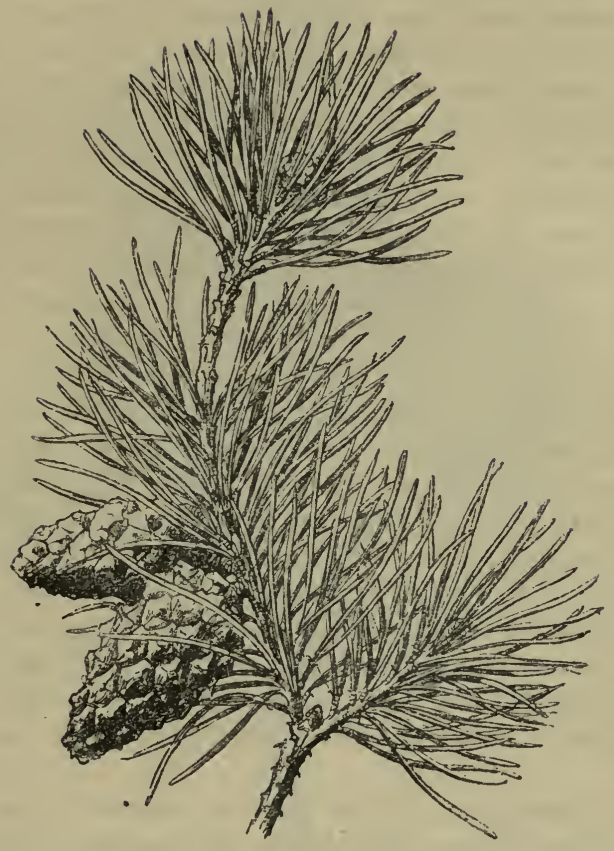

Scotch Pine.

Pinus sylvestris.

- Conifere. - 
The Scotch-pine, as with the reader's permission we will call it, differs much according to the situation in which it is growing. In a favourable locality its trunk will grow to an altitude of one hundred feet, with a girth of twelve feet, whereas in very lofty, exposed situations it is a stunted shrub. Its bark is rugged, and of a ruddy-brown colour. Its needle-shaped leaves are in twos, and last for three years, after which they fall. The flowers are of two kinds. The males consist of many two-celled anthers spirally arranged on a spike, and the spikes are clustered round the new shoots. The female flowers consist each of a green scale, thickened and sticky at the apex and bearing on the inner side of its base two naked ovules. These scales are also associated in a spiral manner round a spike, the whole having a conical form. The male flowers produce an enormous quantity of pollen, which the wind blows in great sulphur-like clouds. Some of the pollen-grains stick to the edges of the scales on the young cones, and the pollen-shoots find their way down to the ovules and fertilize them. In the ripe cone we find, on the scales separating, there are two winged seeds under each scale The timber of $P$. sylvestris is very valuable, and large quantities of it are annually imported from Norway and the shores of the Baltic ; there are numerous varieties of it, known commercially as Red pine, Norway pine, Riga pine, Baltic pine, etc. The tree begins to bear cones between the age of fifteen and twenty years.

It is characteristic of Pines that the branches die off early, and this gives old trees the peculiar appearance of a tall, gaunt, red mast, with a somewhat flat, spreading head.

\section{The Cluster Pine or Pinaster ( $P$. pinaster).}

This is not a native of Britain, though it has been grown here for about three hundred years. Its home is in the countries bordering the Mediterranean, chiefly in low ground near 


\section{$-15^{2}-$}

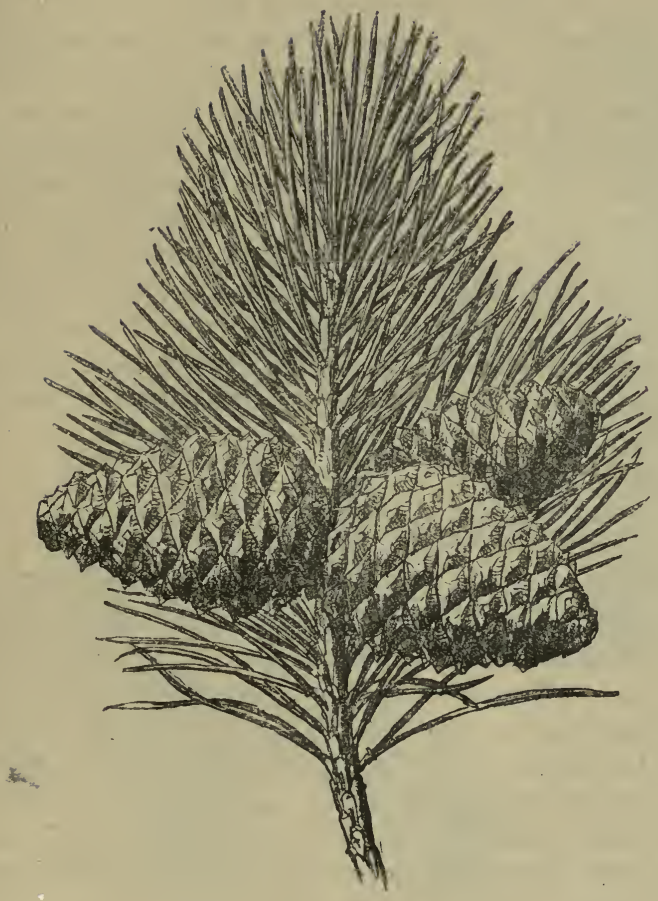

Pinaster.

Pinus pinaster.

- Conifera. - 
the sea. It is a large tree growing to a height of sixty or seventy feet, but its timber is so soft that it has little value for the builder, though the carpenter finds many uses for it, and much of it is used in the preparation of resin, turpentine and tar. The tree may be readily identified by its long, dark leaves (in twos), forming large, brush-like clusters. These leaves vary frorn six to twelve inches in length. The cones are as large again as those of the Scotch-pine, and each scale bears in the centre of the raised portion a hard, sharp point of a grey colour. This is the tree which has proved of such great service in France in turning to use considerable areas of barren sea-sands. In the Departments of the Landes and Gironde troublesome rolling sands have been rendered fit for agriculture by making plantations of $P$. pinaster, which can thrive in such poor stuff, even so near the sea.

\section{The Silver-fir (Abies fectinata).}

Here we have a true fir, which will be seen on examination to differ in several points from the pines. It will at once be noted that the leaves are not gathered into bundles of two, three, or five, but grow solitarily in two rows, on opposite sides of a branch. They are flat, with blunt ends, whitish or silvery underneath, and evergreen. The cones, too, are very different from those of the pines, for whereas those were found to be conical, these are really cylindrical, and consist of a number of woody cones of pretty equal thickness throughout, not thickened at the tips as in Pinus. The firs are excellent timber trees, and are rich in turpentine.

The Silver-fir gets its popular name from the silvery undersides of its leaves. The cones stand erectly from the branches; at first they are green, then reddish, finally purplish-brown. They are six or eight inches in length. Each scale has a long, tapering bract attached to its outer surface, and turned over at 


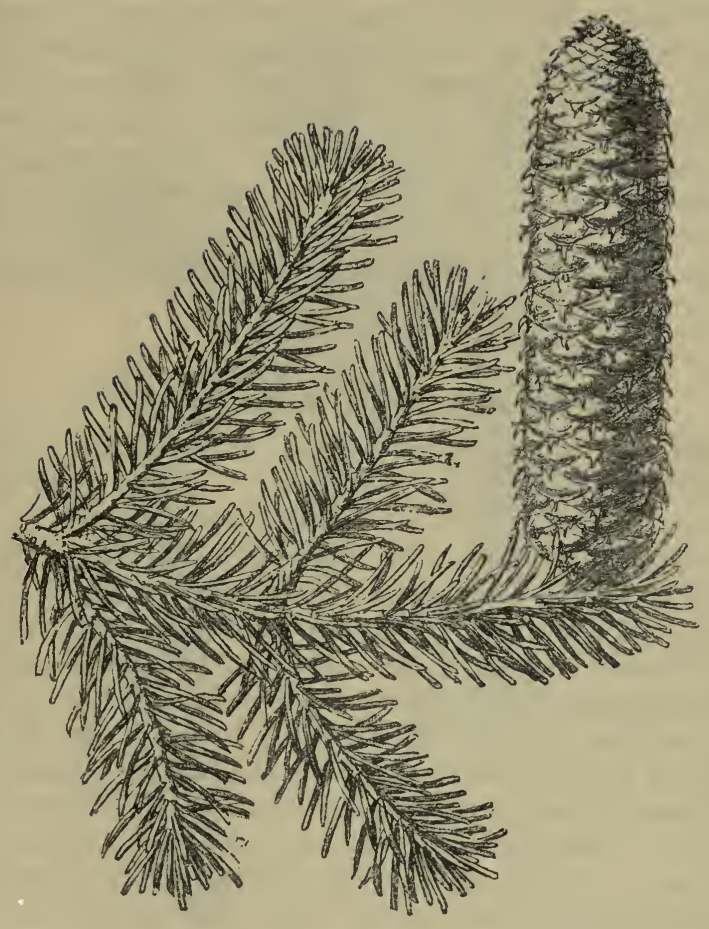

Silver Fir.

Abies pectinata.

- Conifere. - 
the tip. It is a lofty tree, growing to eighty or a hundred feet, sometimes more. It is a native of Central Europe, Northern and Western Asia, but has been grown in England for nearly three hundred years. Its timber is reputed to be durable under water; and from its bark is obtained a resin called Strasburg turpentine, also white pitch. The flowers appear in May, and the cones are ripe eighteen months later. The tree often begins to produce cones at about twenty years of age, but until about its fortieth year these are barren.

The name Abies is Latin, signifying a fir-tree or a plank. A shipwright or carpenter was abietarius.

\section{The Norway Spruce-fir (Abies excelsa).}

The Spruce-fir is a handsome tree, often reaching from one hundred to one hundred and fifty feet in height. The leaves are curiously square, sharp-pointed and scattered in their arrangement on the branch. The cylindrical cones hang down from the tip of a shoot, and are six or seven inches long, their scales with a few teeth at the apex. Its seeds are very small. The flowers appear in May, and the cones ripen in about twelve months. It is a native of Norway, Russia, and Northern Europe generally, and was introduced to Britain nearly three hundred and fifty years ago ; but previous to the glacial period it appears to have been indigenous and prosperous here. Its timber (white deal) is very largely used for many purposes. Its resin is known as frankincense, from which is prepared Burgundy pitch; and from the boiled leaf-buds and shoots is obtained essence of spruce, which is used to flavour an intoxicant known as spruce-beer.

One of the most ornamental of this group is the Hemlock Spruce (Abies canadensis), a species that was introduced about a hundred and sixty years since. Its home is in all the forest regions of Canada and the United States as far west as Oregon, 


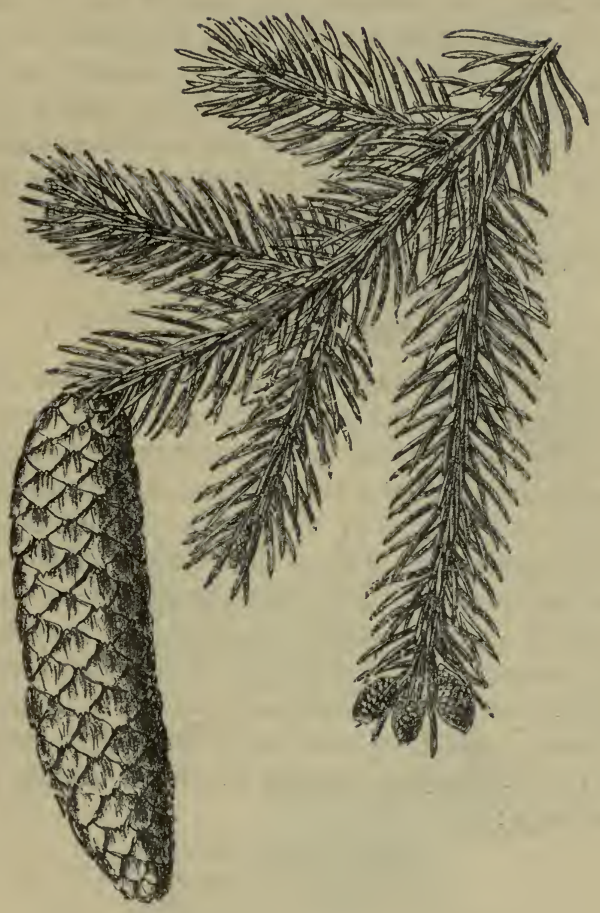

Norway Spruce Fir.

Abies excelsa.

- Conifere. - 
and in New England and the Dominion its shortened name of Hemlock is "familiar in the mouths" of the people. The leaves are short, flat, solitary, and endure for two seasons. The cones are but half an inch long, and afford a striking contrast to those of the Sugar-pine (Pinus lambertiana) whose cones are said sometimes to measure two feet long. The peculiar grace of the Hemlock is due to the symmetrically arranged branches, and to their drooping tips ; but in later life it becomes rugged, and loses much of its charm. Its wood is not so highly esteemed as its bark, which is useful for tanning.

\section{The Larch (Larix europea).}

So frequently do we come across huge plantations of Larch that we might be pardoned for supposing it to be a native tree ; but though it was introduced to Britain as an ornamental tree about two hundred and fifty years ago its true home is in the South European Alps. It is singular in the fact of being a deciduous conifer, that is it sheds all its leaves in the autumn, and remains naked until the spring. A larch-wood in winter presents rather a weird and dreary aspect, the grey branches and trunks appearing as if dead and withered, an aspect that is intensified when, as frequently happens, the branches are thickly invested with the lichens Ramalina and Evernia. But in spring the Larch again becomes a thing of beauty, and, as Tennyson sings :-

\footnotetext{
"Rosy plumelets tuft the Larch, And rarely sings the mounted thrush; And underneath the barren bush Flits by the sea-blue bird of March."
}

These "rosy plumelets" are the future cones, and they are very conspicuous on the bare branches. They become ripe by their first Autumn, when they are but little more than an inch in length, rather oval than conical; erect on the branch, and the scales with irregular margins. When first the leaves 

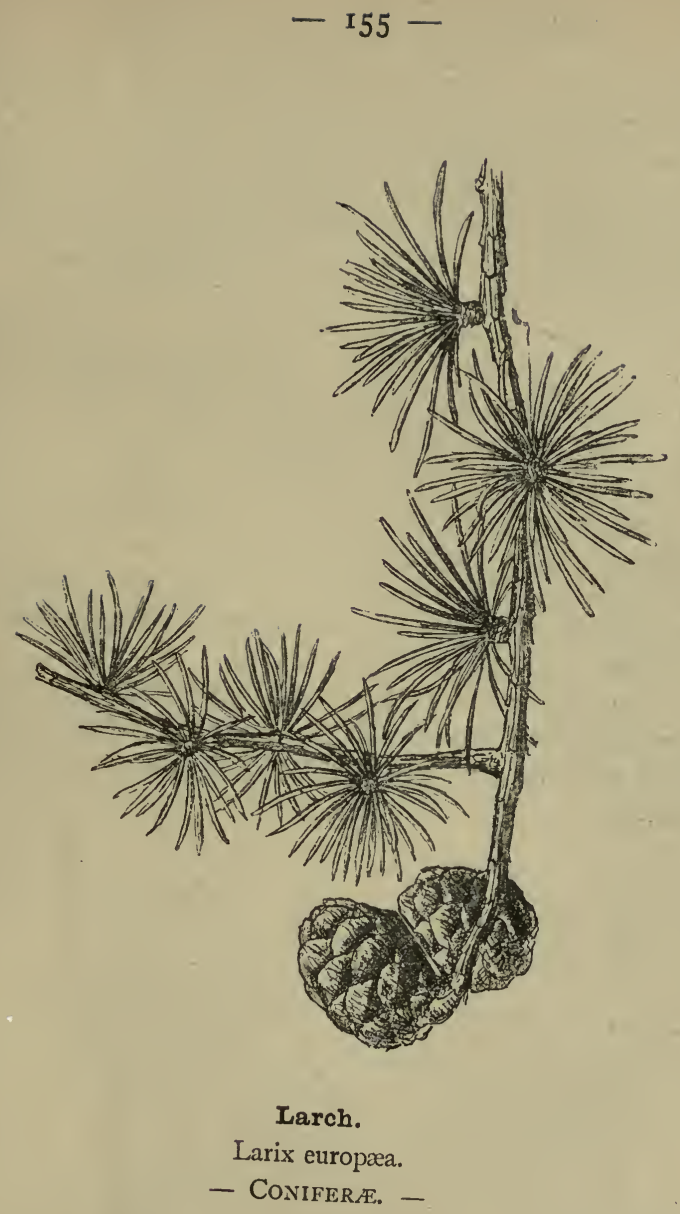
appear they are in tufts, arranged alternately, as shown in our figure, but as the season advances each tuft lengthens into a twig and the leaves become scattered along it as the wood grows - the tree not gaining in good looks thereby. The tree has a wonderfully slender pyramidal form, due to the downward growth of all the branches. It is greatly appreciated as a timber-producing tree, its useful wood being fit to use when the tree is only forty years of age, in which respect it has distinct advantage over the Scotch-pine, which requires eighty years in order to produce serviceable timber. In its early years its annual growth exceeds two feet. At ten years of age from the sowing of the seed it has reached the height of twenty or twenty-five feet, and at fifty years it is eighty feet high. Its natural life is from one hundred and fifty to two hundred years. The Larch and the Spruce-fir have to a great extent supplanted the Scotch-pine in this country, owing to their more rapid growth and development of wood.

In its native countries the bark of the Larch is used for tanning, and the young shoots as fodder for cattle, whilst its resin is an article of commerce under the title of Venice turpentine. 


\section{NATURAL ORDERS, GENERA AND SPECIES}

Ilinstrated or Described in the foregoing pages.

Order I.-Ranunculaceæ.

Genus I.-CLEMATIS vitalba, 82 Genus III-ANEMONE nemorosa, 3i pulsatilla, 4

Genus V.-RANUNCULUS acris, 18 ; bulbosus, 18 ; ficaria, 6 ; repens, 19

Cenus VI.-CALTHA palustris, $\mathrm{x}_{3}$; radicans, $\mathbf{I}_{3}$

\section{Order II.-Berberideæ.}

Genus I. - BERBERIS vulgaris, 57

Order III.-Nymphæaceæ.

Genus I.--NUPHAR luteum, I06; pumilum, 106

Genus II. $-N Y M P H A$ A $A$ alba, 106

\section{Order IV.-Papayeraceæ.}

Genus I.-PAPAVER hybridum, 6r ; arsemone, 6r ; dubium, 6r ; rhwas, $6 \mathbf{I}$

Genus III. - CHELIDONIUM majus, 64

\section{Order V.-Fumariaceæ.}

Genus I.-FUMAR'IA capreo'ata, 9; officinalis, 8 ; densiftora, 9 ; parvifora, 9

\section{Order VI.-Cruciferæ.}

Genus I.* - CHEIRANTHUS cheiri, 12

Genus V.-CARDAMINE hirsuta, II ; pratensis, to ; amara, II; impatiens, Ir.

Genus IX.-BRASSICA nigra, 90 ; sinapis, $90 ;$ alba, 90

Genus XV. - CAPSELLA bursapastoris, II

Order VII.-Resedaceæ.

Genus I. - RESEDA luteola, 79; luted, 79

\section{Order VIII.-Cistineæ.}

Genus I. - HELIANTHEMUM vulgare, 42; folifolium, 42; guttatum, 42; canum, 42 .

\section{Order IX._Yiolaceæ.}

Genus I. - VIOLA palnstris, 58 ; oitorata, 4; hirta, 58 ; canina. $5^{8}$; sylvatica, $5^{8}$; arenaria, $5^{3}$; tricolor, $5^{8}$

\section{Order X.-Polygaleæ}

Genus I. - POLYGALA vulgar is, 28; calcarea, 29; amara, 29 


\section{Order XII. - Caryophylleæ.}

Genus III.-LYCHNIS flos-cuculi,

65 ; diurna, 66; vespertina, 88 Genus IV.-GITHAGO segetum, 7I Genus V.-HOLOSTEU.M umbellatum, 20

Genus VII.-STELLARIA media, 55,62 ; holostea, 62 ; palustris, 62 ; graminea, 62

\section{Order XV. - Hypericineæ.}

Genus I. - HYPERICUM androscemum, 48; perforatum, 47 ; lumifusum, 47; pulchrum, 47; hirsutum, 48 ; tetrapterum, 47

\section{Order XVI. - Malvaceæ.}

Genus II.-MALVA sylvestris, 67 ; rotundifolia, $67 ;$ moschata, 68

\section{Order XVII._Tiliaceæ.}

Genus I.-TILIA parvifolia, 133; platyphyllos, 133

\section{Order XVIII. - Lineæ.}

Genus I.-LINUM catharticum, 95; perenne, 96; allgustifolium, 95; zusitatissimum, 96

\section{Order XIX.-Geraniaceæ.}

Genus I.-GERANIUM molle, 35; rotundifolium, 34; pusillum, 35 ; columbinum, 35; dissectum, 35; robertianum, 35 ; lucidum, 35

Genus II.-ERODIUM cicutarium, 35 ; moschatum, $3^{6}$; maritimum. $3^{6}$
Genus III. $-O X A L I S$ acetosella, II ; corniculuta, I2; stricta, I2

\section{Order XX.-Ilicineæ.}

Genus I.-ILEX aquifolium, 89

\section{Order XXIV.-Sapindaceæ.}

Genus I.-ACER compestre, I3t; pseudo-platanus, 13t;platano:des, I35

\section{Order XXV.-Leguminosæ.}

Genus III. - CY.TISUS scoparius, 7 Genus IV.-ONONIS spinosa, 94; reclinata, 94

Genus VI.-MEDIC.4GO filleatu, 72 ; sativa, 72 ; lupulina, 72 ; denticulata, $72 ;$ maculata, 72 Genus VII.-MELILOTUS altissima, ror ; alba, ror ; officinalis, IOI

Ge:aus VIII. - TRIFOLIUM subterraneum, 48; arvense, 49; pratense, 49 ; medium, 49; striatum, 49; scabrum, 49; repens, 49 ; fragiferum, 49 ; procumbens, 49 ; dubizm, 50

Genus IX.-ANTHYLLIS vulneraria, 52

Genus X. - LOTUS corniculatus, 43; uliginosus, 43; hispidus, 43 ; angustissimus, 43

Genus XV.-ONOBR YCHIS sativa, 50

Genus XVI. - VICIA tetrasferma, 44; hirsuta, 44; cracca, 44; orobus, 44 ; sylvatica, 44 ; sepium, 44 ; sativat, 43 
Order XXVI.-Rosaceæ.

Genus I. - PRUNUS communis, I09; insititia, I09; domestica, I09

Genus II.-SPIR EA ulmaria, 93 ; flipendula, 93

Genus III. $-R U B U S$ ccesius, $3^{\text {T }}$

Genus VI. -FRAGARIA vesca, 27

Genus VII. - POTENTILLA tor-

mentilla, $63 ;$ reptans, $63 ;$ anserina, 62; fragariastrum, 27, 63

Genus IX. - AGRIMONIA eupatoriz, 95

Genus X. - POTERIUM sanguisorba, III; muricatum, III; officinale, III

Genus XI.-ROSA spinosissima, 4I ; rubiginosa, $4 \mathrm{I}$; canina, 4I ; arvensis, $4 \mathrm{I}$

Genus XII.-PYRUS aucuparia, I I7

Genus XIII.-CRAT EEGUS oxyacantha, I7

Order XXVII._Saxifrageæ.

Genus III.-PARNASSI.t palustris, II5

\section{Order XXVIII._Crassulaceæ.}

Genus III.-SEDUMI acre, Ioo.

Genus III.* - SEMPER VIVUM tectorum, Ioo

\section{Order XXIX. - Droseraceæ.}

(ienus I.-DROSERA rotundifolia, 56; intermediu, 57; anglica, 57
Order XXXIV.--Umbelliferæ.

Genus XXII.-FENICUI.U.M officinale, 55

Genus XXV. - ETHUSA cying. pium, II9

Order XXXV.—Araliaceæ.

Genus I.-HEDERA helix, II2

Order XXXVII.-Caprifoliaceæ. Genus IV. - LONICERA periclymenum, $3 \mathrm{I}$; caprifolium, 32

\section{Order XXXVIII.—Rubiaceæ.}

Genus II.-GALIUM aparine, 8\%

\section{Order XXXIX.-Yalerianeæ.} Genus I. - VALERIANA dioicu, I04; officinalis, 104

\section{Order XL.—Dipsaceæ.}

Genus I. - DIPSACUS sylvestris, I07; pilosus, 107

Genus II.-SCABIOSA succisa, 93; culumbaria, 98 ; arvensis, 98

\section{Order XILI.-Compositæ.}

Genus IV.-BELLIS perennis, I Genus XII, - ANTHEMIS arvensis, 46; cotula, 47 ; nobilis, 47 Genus XIII. - ACHILLEA ftarmica, 37 ; millefolium, 36

Genus XVI. - CHRYSANTHEMUM segetum, 53;; leucanthemum, 53; parthenium, 54

Genus XVII. - TANACETUM vulgare, 108 
Genus XXI.-SENECIO vnlgaris, 37 ; sylvaticus, $3^{8}$; viscosus, $3^{8}$; jacobcea, $3^{8}$; erucifolius, $3^{8}$; aquaticus, $3^{8}$

Genus XXII. $-A R C T I U M$ lappa, 87

Genus XXV. - CENTAUREA $n \cdot g r a, 67$; scabiosa, 67; cyanus, 66

Genus XXXI.-CICHORIUM intybus, 68

Genus XXXVII.-HYPOCHबERIS glabra, 97 ; radicata, 97

Genus XXXIX. - TARAXACUM officinale, 20

Genus XLI. - SONCHUS arvensis, II4; palustris, II4; oleraceus, II 4

Genus XLII. - TRAGOPOGON pratensis, 84 ; porrifulius, 84

\section{Order XLII.-Campanulaceæ.}

Genus V.-CAMPANULA rotundifolia, 78 ; trachelium, 78

\section{Order XLIII.-Ericaceæ.}

Genus V.-ERICA tetralix, I20; cincrea, 120 ; ciliaris, 120 ; vagans, 120

Genus VI.-CALLUNA vulgaris, I2I

\section{Order XLVI.-Primulaceæ.}

Genus I.-PRIMULA vulgaris, 3 ; clatior, 3 ; veris, 2 ; farinosa, 3 ; scotica, 3

Genus VI.-ANAGALLIS arvensis, 54 ; tenclla, 54
Order XLVII.-Oleaceæ. Genus II.-FRAXINUS excelsior. 136

\section{Order XLVIII.-Аросуnасеæ.}

Genus I.-VINC.A minor, 5; major, 6

\section{Order XLIX.-Gentianeæ.}

Genus IV. - ER YTHR AEA centaurium, 79

\section{Order LI. -Boragineæ.}

Genus I. $-E C H I U M$ vulgare, 26 Genus I. *-BORAGO officinalis, 80 Genus II. - SYMPHYTUM offcin.tle, 6o; tuberosum, 60 Genus VI. - PULMONARIA angustifolia, ro; officinalis, 9 Genus VII. - MYOSO I'IS palustris, $2 I$

\section{Order LII.-Conyolyulaceæ.}

Genus I.--CONVOL VULUS arvensis, 63 ; sepium, 64; soldanella, 6 . Genus II.-CUSCUTA europaea, 70; epithymum, 70; epilinum, 71

\section{Order LIII._\$olanaceæ.}

Genus I.-HYOSCYAMUS niger, 39

Genus II.-SOLANUM dulcamara, 99; nigrum, 99

\section{Order LIV.-Plantagineæ.}

Genus I.-PLANTAGO major, 22; media, 23 ; lanceolata, 22 ; maritima, 23 ; coronopus, 23 
Order LV. - Scrophularineæ.

Genus II.-LINARIA cymbalaria, 33; spurin, I05; elatine, 105; vulgaris, 105; repens, 105; minor, 105

Genus VIII.-VERONICA chamedrys, 28 ; beccabunga, 29

Genus X.-EUPHRASIA officinalis, 50

Genus XIII. - MEL.AMPYRU.M pratense, 9I ; sylvaticum, 9I ; arvense, 91 ; cristatum, 92

\section{Order LIX. - Labiatæ.}

Genus I.-MENTHA sylvestris, 59; rotundifolia, $5^{8}$; piperata, 59 ; aquatica, 59; sativa, 59; arvensis, 59 ; pulegium, 60

Genus IV. - THYMUS serpyllum, 85

Genus VI.-SALVIA pratensis, 23

Genus VII. - NEPETA cataria, 34; glechoma, 33

Genus VIII,-BRUNELLA vulgaris, 83

GenusXIV.-LAMIUMpurpureum, 3.3; intermedium, 33 ; amplexicaule, 33 ! album, 33 ; galeubdolon, 33

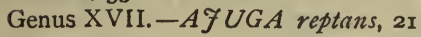

\section{Order LXI.-Chenopodiaceæ.}

Genus I.-CHENOPODIUM vulvaria, 86; polyspermum, 86; album, 86; rubrum, 86; bonushenricus, 86

\section{Order LXII.-Polygonaceæ.}

Genus I.- $P O L Y G O N U M$ bistorta, 118 ; amphibium, 118 ; persicaria,
II8; aviculare, II9; convolvulus, I19; fasopyrum, II8

Order LXV.-Elæagnaceæ. Genus I. - HIPPOPHAE rhamnoides, 92

Order LXVI.-Loranthaceæ.

Genus I.--VISCUM album, I2I

Order LXVIII.-Euphorbiaceæ.

Genus I.-EUPHORBIA helioscopia, зо; platyphyllos, 30 ; hiberna, 30 ; anygdaloides, 30 ; peplus, 3o; exigua, 30 ; portlandica, 30 ; paralias, 30 ; esula, $3 \mathbf{1}$; lathyris, 3I ; peplis, $3^{\mathbf{I}}$

Order LXIX.-Urticaceæ.

Genus I.-ULMUS montana, $\mathrm{x}_{3} 8$; campestris, 138

Genus II.-URTICA urens, I03; dioica, Iо3; pilulifera, 103

Genus IV.-HUMULUS lupulus, I 10

\section{Order LXXI.-Cupuliferæ.}

Genus I. $-B E T U L A$ albar, I49 Genus II.-ALNUS glutinosa, 150 Genus III.-QUERCUS robur, I42 Genus IV.-FAGUS sylvatica, I40 Genus V.-CORYLUS avellana, I44 Genus VI.-C.ARPINUS betulu.s, I45

\section{Order LXXII._-Salicineæ.}

Genus I.-POPULUS alba, I47; tremula, 147 ; fastigiata, 147 Genus II. $-S A L I X$ viminalis, $\mathrm{I}_{4} 6$ 
Order LXXIV.-Coniferæ.

Genus I.-PINUS syluestris, I5I; pinaster, 152

Genus II.-FUNIPERUS commu$n$ is, 102

\section{Order LXXVI.-Orchideæ.}

Genus I.-MALAXIS pulludosa, 77 Genus II.-LIPARIS locselii, 77 Genus IV.-NEOTTIA nidus-avis, 77

Genus V.-LISTERA ovata, 77 Genus VII.-SPIRANTHES autumnalis, 77

Genus XI.- ORCHIS latifolia, 74; hircina, 76

Genus XIII.-OPHR YS apifera,76; aranifera, $76 ;$ muscifera, 76 Genus XV.-HABENARIA bifolia, 76

\section{Order LXXVII.-Irideæ.}

Genus III.-IRIS pscudacorus, 73; fotidissima, 73

Order LXXX. - Liliaceæ.

Genus III.-POL YGONA TUM verticillatum, 17 ; multiforum, 16; officinale, $\mathbf{1 7}$

Genuis V.-CONVALLARIA majalis, 16

Genus IX.-SCILLA verna, 15; autumnalis, 15 ; nutans, 14

Genus XV.-COLCHICUA autumnalc, 122

\section{Order LXXXI.-Junceæ.}

Genus II.-LUZULA maxima, 69; vernalis, 69 ; forsteri, 69 ; cam- pestris, 70; spicata, 70 ; arcuata, 70

\section{Order LXXXIII.-Typhaceæ.}

Genus II. -TYPHA latifolia, 55 : angustifolia, 52

\section{Order LXXXIV.-Aroideæ.}

Genus I.-ARU.II maculatum, ${ }_{5}$; italicum, $\mathbf{1} 6$

\section{Order LXXXV. - Lemnaceæ.}

Genus I.-LEMINA minor, 45 ; trisulca, 46; gibba, 46; polyrhiza, 46

\section{Order LXXXVI. - Alismaceæ.}

Gerus IV.-S.AGITTARIA sagittifolia, Ir3

\section{Order LXXXVII.-Naiadaceæ.}

Genus III.-POTAMOGETON natans, $8 \mathrm{r}$; polygonifolius, $8 \mathrm{r}$; plantagineus, $8 \mathrm{I}$; prelongus, 82 ; crisfus, $8 \mathrm{I}$; densus, 8r

\section{Order LXXXIX.-Gramineæ.}

Genus VI.-ANTHOXANTHUM odoratum, 25

Genus VIII. - ALOPECURUS agrestis, 40; alpinus, 40; pratensis, 40 ; renticulatus, 40

Genus X.-PHLEUM pratense, 25 Genus XXV.-AVENA fatua, I16; pratensis, II6; pubescens, II7; sativa, II6

Genus XXXVI. -DACTYLIS glomerata, 24

Genus XXXVII. $-B R I Z A$ media, 40; minor, 40 
NATURAL ORDERS, GENERA AND SPECIES.

Genus XXXVIII.-POA annua, 24 Genus XLI.-BROMUS erectus, $3^{8}$ Genus XLIII. - LOI.IUM perenne, $3^{8}$; temulentum, 39

Genus XLVII.-HORDEUM murinum, 19

Order XC.-Filices.

Genus VII.-ASPLENIUA trichomancs, 124 ; viride, 124
Genus VIII.-SCOLOPENDRIUM vulgare, 123

Genus XII. - NEPHRODIUM filixmas, 124; spinulosum, 125: oreopteris, 125

Order XCI.-Equisetaceæ.

Genus I.-EQUISETUM arvense, I:25

\section{EXOTIC GENERA.}

Order Xanthoxylaceæ. AILANTUS glandulusa, rзo

Order Leguminosæ.

ROBINIA pseudacacia, 132

Order Arctocarpeæ. MORUS nigra, ז34
Order Cupuliferæ. CASTANFA vulgaris, $13^{8}$

Order Platanaceæ. PLATANUS oricntalis, $\mathrm{I}_{48}$

Order Coniferæ.

$L A R I X$ europcea, I55 ABIES cxccls.x, I54 ; pectin rtr, $\mathbf{1 5 3}$ 



\section{N D E X.}

(The popular names are printed in italics.)

PAGE

ABIES excelsa . $\quad \therefore \quad$ I54

" pectinata : : I53

Acer campestre ${ }^{\circ}$. . 134

, pseudo-platanus . . I34

", platanoides . . . I35

Achillea millefolium . . . $\quad 3^{6}$

, ptarmica . . . 37

Æthusa cynapium . . . II9

Agaricus campestris . . . I II

, muscarius . . . $13 I$

Agrimonia eupatoria . . 95

Agrimony . : : . 95

Ailantus glandulosa : . . 133

Ajuga reptans . . . . $2 \mathrm{I}$

Alder . . . . . 150

Alnus glutinosa : : . I50

Alopecurus agrestis . . . 40

" alpinus . $\quad$ geniculatus 40

"geniculatus . . 40

, pratensis . . 40

Anagallis arvensis . . 54

," tenella : : • 54

Anemone nemorosa : : . 3

" pulsatilla . . . 4

Annual Meudoiv-grass . . 24

Anthemis arvensis . . . 46

" cotula . . . 46

" nobilis . . . 47

Anthoxanthum odoratum . $\quad 25$

Anthyllis vulneraria . . . 52

Arum maculatum . . . . I5 $_{5}$

Arum italicum . . . . I6
Arctium lappa . . . . 87

Arrow-head . : . . II3

Ash. . . . : . 136

, Mountain. . . . II7

Asplenium trichomanes . . 124

- 24

Avena fatua . . . . II6

, pratensis . . . Ir6

, pubescens . . . II7

" sativa . . . . II6

BARBERRY . • . . 57

Barley, Wall : . . . 19

Beech . . . . 139

Eee Orchis . . . . 76

Bellis perennis . . . . $\mathrm{x}$

Berberis vulgaris . . 57

Betula alba : . . 149

Bindweed, Small . . . 63

Birch . . . . 149

Bird's-eye Primrose . . . 3

Bird's-foot Trefoil . . . 43

Biting Stonecrop : . . roo

Bittercress . . . . 10

Bitterswict . . . . 99

Blackthorn. . . . . rog

Blue-bell . . . . . 78

Blue-bottle . . . 66

Boletus eduli; . . . . $\mathrm{r}_{3} \mathbf{r}$

Borage . . . . 80

Burago officinalis . . . 80

Biandy Bottle . : . . re6 
Briza media

media

minor

Brassica alba

, nigra.

" sinapis

Brome-grass

Bromus erectus.

Broom

Brunella vulgaris

Buckwheat

Bugle

Burdock .

Buttercup.

Butterfy Orchis

CALLUNA vulgaris

Caltha palustris

radicans

Campanula rotundifolia . $\quad 7^{8}$

Campion, Red .

trachelium . .78

White . . . 88

Cantharellus cibarius

Capsella bursa-pastoris

Cardamine amara

hirsuta

$"$

impatiens

pratensis .

Carpinus betulus

Castanea vulgau is

Cat-mint .

Cat's-ear

Cat's-tail Grass

Cat's-Valerian .

Celandine, Lesser

Greater .

Centaurea cyanus

$$
\text { nigra }
$$

," scabiosa.

Centaury .

Chanterelle
I2I

3

Charlock.

PAGE

Cheiranthus cheiri " . " .

Chelidonium majus . . . 64

Chenopodium album . $\quad$. 86

," bonus-henricus . 86

" polyspermum . 86

", rubrum . . 86

, vulvaria . . 86

Chestnut . . . . . . Ifr

Chicory • • • • . 68

Chickrveed . . . . 55

Chickrveed, Figged . . . 20

Chrysanthemum leucanthemum 53 parthenium . 54

" parthenium

53

Cichorium intybus . . . 68

Cladonia pyxidata . . . 128

rangiferina. . . 128

Clematis vitalba . . . 82

Clovers . . . . . 43

Cluster-pine . . . . ${ }_{52}$

Cock's-foot grass . $\quad$ • $\quad$. 24

Colchicum autumnale . . 122

Comfrey . . . . 60

Convallaria majalis . . . $\quad$ r6

Convolvulus arvensis $\quad . \quad$. 63

" sepium . . . 64

Corn-cockle . . . . $7 \mathbf{I}$

Corn Channomile . . . 46

Corylus avellana . . . I44

Conslip . . . . . 2

Cow-whent . . . . 9I

Crane's-bills . . . . 34

Cratægus oxyacantha $\quad$. $\quad$ I7

Cuckoo-flower . . . . Io

Cuckoo-pint . . . . $\mathbf{I}_{5}$

Cup-moss . . . . . 128

Cuscuta epilinum . . . 7 I

" epithymum . . . 70

" europrea . • . 70

Cytisus scoparius 
DACTYLIS glomerata Daisy

Dandelion

Dead-ncttles

Dewberry .

Dipsacus pilosus

sylvestris

Dodders

Dog-rose

Drosera anglica

intermedia

rotundifolia

Duckweeds

ECHIUM vulgare .

Elm.

Equisetum arvense

Erica ciliaris

" cinerea . .

" vagans . . . . 120

Erodium cicutarium . . . 35

maritimum . $\quad 3^{6}$

" moschatum . . $3^{6}$

Erythræa centauriım . . 79

Luphorbia amygdaloides . 30

", cyparissias . . 30

". esula $. \quad . \quad . \quad 3^{I}$

" exigua . . . jo

" helioscopia . . 30

", hiberna . . . 30

" lathyris . . . $3^{\mathrm{r}}$

" paralias . . . 30

" peplis . . . $3^{\mathrm{r}}$

" peplus . . . 30

". platyphyllos . . 30

, portlandica . . 30

Euphrasia officinalis . . 50

Eyebright. . . . . 50

FAGUS sylvatica
False Acaciu .

Fennel . . . . 55

Field Horsetail . . . 125

Fine-leaved Heath . . . 120

Flag. . . . . . 73

Flax. . . . . . 96

Fœniculum officina.c . $\quad 55$

Fool's Parsley . . . . II9

Forget-me-not . . . . 21

Foxtail Grasses . . . 40

Fragaria vesca . . . . 27

Fraxinus excelsior : . . $1 \hat{\jmath}^{6}$

Fumaria capreolata . . . $\quad 9$

," densiflora . . . 9

, officinalis . . . 8

, p.rviflor . . . 9

Fumitory. $\quad$. $\quad$ : $\quad . \quad$. 8

Fungi . . . . . r₹o

G.ALIUM aparine . $\quad \cdot \varepsilon_{7}$

Geranium columbinum . . $3 \overrightarrow{5}$

" dissectum. . . $3 \vec{\jmath}$

" lucidum . . . 35

" molle . . . 35

" pusillum . . . 35

", robertianum . . 35

". rotundifolium : . 34

Githago segetum . . 75

Goat's-bcard . . . . 84

Goosefoot . . . . . 86

Goose-grass • . . . 87

Grass of Parnassus . . . II5

Greater Celandine : . . 64

Ground Ivy . . . . 33

Groundsel. . . . . 37

HABENARIA bifo!ia . . 76

Hairbell . • . . $\quad 78$

Hart's-tongue Iiern . . . 123

Hawthorn . , . . 17

Hazel . . . . . I 44 
PAGE Heaths . . . . 120 Hedera helix . . . . II2 Helianthemum canum . . 42 ,, guttatum . : 42 $\begin{array}{lll}\text { " } & \text { polifulium } & \text {. } \\ \text { " } & \text { vulgare } & 42\end{array}$ Henbane . . . . . 39 Hippcphae rhamnoides . $\quad$. 92 Holly • • . . . 89 Holosteum umbellatum . . 20 Honeysuckle . • . . $3^{\mathrm{I}}$ Hop. • . . . . 11 Hordeum murinum . . . 19 Hornbeam Horsetails Houseleek . Humulus lupulus . . . I Iо Hyacinth, Wild • . . Is Hyoscyamus niger . . . 39 Hypericum androsæemum. . $4^{8}$

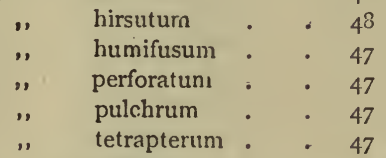

Hypochœris glabra - • $\quad$. 97 " maculata . . 97 " radicata. . . 97 Hypnum triquetrum . : . ז 30

ILEX aquifolium . . $\quad 89$ Iris fotidissima . . . 73 , pseudacorus : . . 73 Iris, yellow . : : $\quad 73$ lvy , . . . . . . II Ivy-leaved Toadfix. . . 33

FAGGED Chickweed . . 20 Funiper . . . . . 102 Juniperus communis . . .
KIDNEY Vetch

PAGE

$5^{2}$

$L A D Y^{\prime} S$ Smock . . . Is

Lamium album • • • 33

,, amplexicaule . $\quad 33$

, galeobdolon . . 33

, . intermedium . . 33

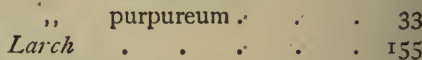

Larix europea . . . . I55

Lecidea geographicd • • 129

Lemna gibba . . . . 45

" minor . . . . 45

", polyrhiza . . . 45

," trisulca . . . 45

Lesser Celandine . . . 6

Lichens . . . . . 127

Lily of the Valley . . . . I6

Lime-trees . . . . I33

Linaria cymbalaria . . . 33

" elatine. . .

, ininor . . . $10 j$

,, repens. . . roj

,, spuria . . . 105

,, vulgaris . . . $\mathrm{ro}_{5}$

Linum angustifolium . $\quad .96$

, catharticum . . . 95

,, perenne. . . . 95

, usitatissimum . . 96

Listera ovata - . . . 77

Lolium perenne . . . $3^{8}$

," temulentum. . . 39

Lombardy Poplar . . . . I47

Lonicera caprifolium . $\quad 3^{\mathrm{I}}$

. ", periclymenum . . $3 I$

Lotus angustissimus . . . 43

" corniculatus . . . 43

" hispidus. . . 43

Lotus uliginosus : : 43

Lucerne - . . . . 72

Lungrvort. . . . . 9 
YNDEX.

Lumula arcuata . 70

" campestris . . . 70

" forsteri . . . . 69

", maxima. . . . 69

". spicata . . . . 70

, vernalis. . . . 69

Lychnis diurna . . . . 66

" flos-cuculi . . . 65

,. vespertina . . . 88

Lycoperdon gemmatum . $\quad$ I3I

, giganteum . . I3I

MAIDENHAIR Spleenwort . I24

Malaxis paludosa . . . 77

Male-fern. . . . . 124

Mallows . . . . . 67

Malva moschata . . $\quad 68$

" rotundifolia . . . 67

", sylvestris . . . 67

Maples . • . . . I34

Marsh Marigold . . . I3

. Orchis . . . . 74

Meadow Fox-tail-grass . . 40

Mcadow-grass : . . . 24

Meadow Saffron . . . 122

Meadow Sage . . . . $=3$

Meadow Sweet . . . . 93

Medicago denticulata $\quad$ - 72

" falcata . . . 72

, lupulina . . . 72

" maculata. . . 72

. sativa . . . 72

Medick, Purple . . . 72

Melampyrum arvense . . GI

cristatum . . $9 r$

pratense - . $9 \mathrm{I}$

sylvaticum . . 9I

Melilot . . . . IOI

Melilotus alba . . . . IOI

Melilotus altissima . . . IOI

officinalis
Mentha aquatica

59

arvensis . . . 59

piperata . . . 59

pulegium . . . 60

rotundifolia . . . 58

sativa . . . $\quad 59$

sylvestris . . . 59

Mignonette, Wild .. $\quad . . \quad$. 79

Milfoil . . . . . 36

Milkworts. . . . . 28

Wints . . . . . $5^{8}$

Mistleto . . . . . . I2I

Morus nigra $\quad$ • $\quad$ • $\quad$. $\quad$. I37

Mosses . . . . . 129

Mountain Ash . . . . II7

Mulberry . . . . . $\mathrm{I} 37$

Musci . . . . . 129

Mushrooms . . . . 130

Mustards . . . . 90

Myosotis palustris . . . 21

NEOTTIA nidus-avis . $\quad$. 77

Nepeta cataria. . . . 33

glechoma . . 33

Nephrodium spinulorum . . I25

. filix-mas . . 124

" oreopteris . . I25

Norvay Spruce-fir . . . I54

Nuphar luteum. . . . . . I05

", pumilum . . . . 106

Nymphæa alba. . . . 106

$O A K$ • . . . I I 2

Oat-grass . . . . . II 6

Onobrychis sativa . . . 50

Ononis reclinata . . . 94

". spinosa. . . . 94

Ophrys apifera . . . . . 76

." aranifera . . . 76

". muscifera . . . 76

Orchids, British ․ $74,75,76,77$ 
Orchis hircina . . . $7^{5}$ " latifolia. . . . 74

Osier . . . . . I46

Oxalis acetosella $\quad . \quad$. $\quad . \quad$ II

" corniculata . . . 12

", stricta . . . . 12

Ox-eye Daisy . . . . 53

Oxlip . . . . . 3

PANSY, Wild . . . $5^{8}$

Papaver argemone . . . . 6I

, dubium . . . 6r

" hybridum . . . $6 \mathrm{r}$

" rhœas. . . 60

Parmelia perlata . . . 129

" saxatilis • • $\because$ I29

Parnassia palustris . . . II $5_{5}$

Periwinkle . . . . 5

Phleum pratense . . . 25

Physcia parietina . . . I29

Pilewort . . . . . 6

Pimpernel . . . . 54

Pinaster . . . . $\mathbf{I}_{52}$

Pinus pinaster . . . . $\mathrm{I}_{52}$

, sylvestris. . . . I5I

Plane-trees . . . . $\mathbf{I} 48$

Plantago coronopus . . . 23

" lanceolata. . . 22

, major . . . 22

", maritima . . . 23

" media . . . 23

Plantains . . . $\therefore 22$

Platanus occidentalis . . 149

" orientalis . • 148

Poa annua . . . . 24

Polygala amara $\quad$. $\quad 29$

" calcarea . . . 29

", vulgaris : . 23

Polygonatum multiflorum . . 16

.. officinale . . 17

, verticillatum . 17
PAGE

Polygonum amphibium . . 118

aviculare . . II9

bistorta . . . $\mathrm{r} \mathbf{1} 8$

convolvulus . . I 19

fagopyrum . . II8

persicaria . . 118

Polytrichum formosum , . $\mathrm{I}_{30}$

Pond-zuceds . . . . $8 \mathbf{I}$

Poplar . . . . . 147

Poppy . . . . . 60

P'opulus alba . . . . $\quad$ I 47

" fastigiata . . . $\mathrm{I}+7$

" tremula . . . 147

Potamogeton crispus . $8 \mathrm{r}$

$8 \mathrm{I}$

$8 \mathrm{r}$

$8 \mathrm{r}$

$8 \mathrm{r}$ \begin{tabular}{lll} 
polygonifolius & $\cdot$ & $8 I$ \\
prælongtis : & $\cdot$ & $8 I$ \\
\hline & $\cdot$ & 62
\end{tabular} \begin{tabular}{lll} 
polygonifolius & $\cdot$ & $8 I$ \\
prælongtis : & $\cdot$ & $8 I$ \\
\hline & $\cdot$ & 62
\end{tabular} $\begin{array}{ccc}\text { ". polygonifolius } & \cdot & 8 \mathrm{I} \\ \text { ". prælongtis : } & \cdot & 8 \mathrm{I} \\ \text { Potentilla anserina . } & . & 62\end{array}$

, fragariastrum . $27,6_{3}$

," reptans . . 63

") tormentilla . . 63

Poterium muricatum . . III

, officinale .. . . III

" sanguisorba . . II I

Primrose . . . . . 2

Primula elatior . . . 3

, farinosa . . . 3

", scotica . . . 3

" veris . . . . 2

," vulgaris . . . 3

Prunus communis . • . 109

domestica . . . 109

insititia. . . 109

Puff-balls. . . . . $\mathbf{1}_{3} \mathbf{I}$

Pulmonaria angustifolia . . ro

- ." officinalis . . 9

Pyrus aucuparia . . . II7 
QUAKE-grass

PAGE

Quercus robur.

40

142

RAGGED Robin . . . 65

Ragrworts .

Ranunculus acris

I8

bulbosus

ficaria

Reed-mace

repens

Reseda lutea

luteola .

Rest-Harrow

Robinia pseudacacia.

Rock-rose .

Rosa arvensis

, canina

" rubiginosa

" spinosissima

Rowan

Rubus cæesius

Rye-grass .

SAGITTARIA sagittifolia

Sainfoin .

Saint Fohn's Worts.

Salad Burnet .

Salix viminalis

Salvia pratensis

Scabiosa arvensis

columbaria .

succisa

Scabious.

Scilla autumnalis

" nutans

," vernalis

Scolopendrium vulgare

Scotch-pine or fir

Scottish Primirose

Sea-Buckthorn .

Sedum acre

x9

5 I

79

79

94

I 35

42

4I

$4 \mathrm{I}$

$4 \mathrm{I}$

$4 I$

II7

3 I

$3^{8}$

23

98

98

98

I5

123

I5 $\mathrm{r}$
Self-Heal .

PAGE

Sempervivum tectorum . . I00

Senecio aquaticus . $\quad . \quad . \quad 3^{8}$

, erucifolius. . . . $3^{8}$

", jacobæa . . . $3^{8}$

, sylvatica . , . $3^{8}$

, viscosa . . . $3^{8}$

". vulgaris . . . 37

Shepherd's purse

II

Silver-fir.

I53

Silverweed . . . . 62

Sloe. . . . . . 109

Sneezerwort . . . . 37

Solanum dulcamara . $\quad$. $\quad$. 99

nigrum . . . 99

Solomon's Seal . . . . I6

Sonchus arvensis $\quad . \quad$. . II4

" oleraceus . . . II4

Sow-thistles . . . . . II4

Speedruell . . . . . 28

Spiræa filipendula . . 93

" ulmaria. . . . 93

Spiranthes autumnalis . . 77

Spruce-fir. . . . . ${ }_{54}$

Spurges . . . . . 29

Squills . . . . . $\mathrm{I}_{4}$

Stellaria graminea . . . 62

98

I4

I5

92

IOO holostea . . $6 \mathbf{I}$

" media. . . 55, 62

, palustris . . . 62

Stinging-nettles . . . 103

Stitchworts . . . . 6I

Stonecrop . . . . I00

Stork's-bills . . . . 35

Strawberry, Wild . . . 27

Sunderws . . . . $\quad 56$

Sweet Violet . . . . 4

Sycamore . . . . $\mathrm{r} 34$

Symphytum officinale . . 60

, tuberosum . . 60 
PAGE

TANACETUM vulgare . . I08 Tansy . . . . . 108

Taraxacum officinale . 20

Teasels . . . . . 107

Thyme . . . . . 85

Thymus serpyllum . . . 85

Tilia parvifolia . . . . 133

„, platyphyllos . . . 133

Timothy-grass . . . . 25

Toadflax . . . 33, 105

Totter-grass . . . . 40

Tragopogon porrifolius . $\quad 84$

" pratensis • $\quad 84$

Traveller's foy . . . 82

Tree of the Gods . . . 133

Trifolium arvense . . . 49

", dubium . . . 50

," fragiferum . . 49

". medium . . . 49

" pratense . . . 49

" procumbens . . 49

", repens . . . 49

", scabrum . . 49

" striatum . . . 49

, subterraneum . . 48

Typha angustifolia . . . $5^{\mathrm{I}}$

" latifolia. . . . $5^{\mathrm{I}}$

ULMUS campestris . . ${ }_{13}^{8}$ montana . . 138

Urtica dioica . . . . I03

", pilulifera . . . I03

, urens . . . . I03

VALERIANA dioica . . 104 " officinalis . . IO4 Vernal Grass . . . . 25 Vernal W'oodrush . . . 69
Veronica beccabunga

PAGE

" chamædrys

29

Vetch chamadrys

Victe. $\cdot 43$

Vicia cracca . . . . 44

,, hirsuta . . . . 44

," orobus . . . . 44

", sativa . . . . 43

, sepium . . . . 44

" sylvatica . . . . 44

" tetrasperma . . . 44

Vinca major . . . . 5

" minor . . . . 5

Viola arenaria . . . $\quad 5^{8}$

", canina . . . . $5^{8}$

" hirta . . . . $5^{8}$

" odorata . . . . 4

", palustris . . . . $5^{8}$

., sylvatica . . . . $5^{8}$

," tricolor . . . . 58

Viper's Bugloss . . . 26

Viscum album . . . . 121

WALL Barley . . . 19

Wallfower . . . . 12

Wall Lichen . . . . 128

Water Lily . . . . 106

Weld • • . . . 79

Wild Hyacinth . . . 13

Wood Anemone . . . 3

Woodrush . . . . 69

Wood Sorrel . . . . II

$Y A R R O W \quad \cdot \quad \cdot{ }^{6} 6$

Yellow Flag • • • . 73

Melilot . . . . IOr

Stonecrop . . . Ico

Toadflax . . . 105

Water lily . . 106 
A STANDARD WORK ON BRITISH WILD FLOWERS.

In four vols., royal 8vo, cloth gilt, gilt top, £3.

THE FLOWERING PLANTS, GRASSES, SEDGES AND FERNS OF GREAT BRITAIN, and their Allies, the Club-Mosses, Pepperworts and Horsetails. By ANNe PratT. New Edition, containing 318 Plates. In Four Volumes, royal $8 \mathrm{vo}$, cloth gilt, gilt top.

\section{USEFUL MANUALS FOR LOVERS OF NATURE.}

In small crown 8vo, picture cover boards, price is. each.

ENGLISH WILDFLOWERS, to be found by the Wayside, Fields, Hedgerows, Rivers, Moorlands, Meadows, Mountains and Sea-shore. By J. T. BuRgess. With Practical Illustrations.

THE COMMON SEA-WEEDS OF THE BRITISH COAST AND CHANNEL ISLANDS. With some Insight into the Microscopic Beauties of their Structure and Fructification. By Mrs. L. Lane Clarke. With Original Plates printed in Tints.

THE COMMON SHELLS OF THE SEA-SHORE. By the Kev. J. G. WoOD.

"The book is so copiously illustrated that it is impossible to find a shell which cannot be identified by reference to the engravings." Vide PREFACE.

In small crown 8vo, cloth, price Is. each.

A FERN BOOK FOR EYERYBODY. Containing all the British Ferns, with the Foreign Species suitable for a Fernery. With numerous Illustrations and Coloured Plates. By M. C. CoOKe.

ONE THOUSAND OBJECTS FOR THE MICROSCOPE. By M. C. COOKE. With 500 Illustrations. Twelve pages of Tinted Plates. 

C

$12 x-1+2 y$ (I) (1) I). $\rightarrow \sqrt{2}+2$

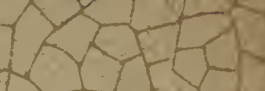

ing $\lim _{x \rightarrow \infty}$ acyirs

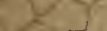
$c^{2}=3$. - Lif (2) $\underbrace{}_{3=1}$ $\operatorname{lit}_{1}+t_{2}$

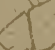
13 $\int_{x}^{2}$

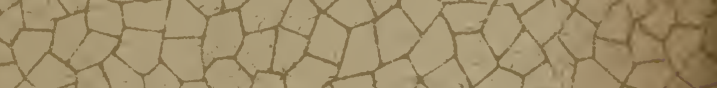
$1>1>1$ $3 x^{2}$ ᄀ $\rightarrow+1$ 3

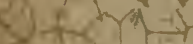

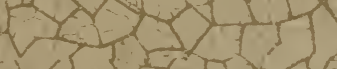
$\operatorname{li}_{-2}$

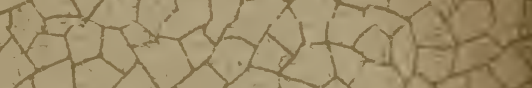

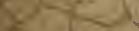
(I) 1 ) ro 31 건 $+x$ so $+1=$ $S_{1}$

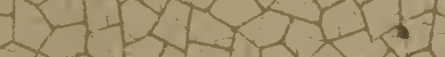
$4 \sqrt{1}+2)$ . $32>2$

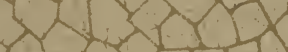

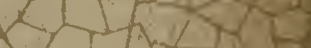
$x^{2}+x^{2}$ $x+1>2$ 2 $<1$

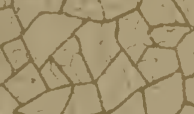
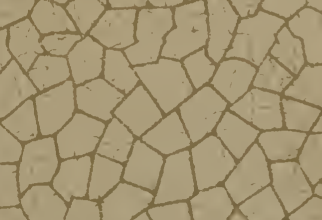
12
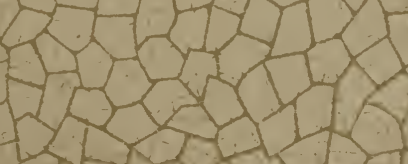
$1-x+7, x-2$ 
